\title{
MILNEY CHASIN
}

\section{POLÍTICA, LIMITE E MEDIANIA EM ARISTÓTELES}

Tese apresentada ao Programa de Pós-graduação em História da Faculdade de Filosofia, Letras e Ciências Humanas da USP, como requisito parcial para obtenção do título de Doutor. Linha de pesquisa: História Social. Orientador: Prof. Dr. Jorge Luís da Silva Grespan.

FACULDADE DE FILOSOFIA, LETRAS E CIÊNCIAS HUMANAS UNIVERSIDADE DE SÃO PAULO SÃO PAULO 


\title{
MILNEY CHASIN
}

\section{POLÍTICA, LIMITE E MEDIANIA EM ARISTÓTELES}

\author{
Orientador: Prof. Dr. Jorge Luís da Silva Grespan
}

\section{UNIVERSIDADE DE SÃO PAULO}

São Paulo

2007 
À memória de José Chasin, meu pai, um intelectual aguerrido; um homem forte que, por seu exemplo e idéias, marcou nossas vidas.

À memória de Hanna, minha mãe, que soube, na máxima enfermidade, tomar a decisão certa. 


\section{Agradecimentos}

Agradeço, em primeiro lugar, a acolhida generosa de meu trabalho por parte de Jorge Grespan, que soube compreender seus objetivos e fins, principalmente quando se pensa nos tempos vividos, de uma ciência da história pouco afeita aos movimentos concretos da realidade, da sensibilidade e da imanência dos fatos; logo, em um fazer pouco orientado ao ser, ou melhor, não desejosa de tomá-lo como pressuposto e condição de si, de sua inteligibilidade.

Agradeço, também, a Rago e a Pedro Paulo Funari, por suas sugestões expostas no exame de qualificação que norteou este estudo; a Ester e a Iba, pelo apoio ativo de ambos que, sem dúvida, muito me ajudou neste caminho constitutivo; a Cleyde, minha revisora, por seu trabalho, que revelou pertinência e sensibilidade; e especialmente a Nádia, minha mulher que, com a paciência que lhe é peculiar, soube ser companheira em momentos difíceis e de ausência no convívio familiar. 
BANCA EXAMINADORA

PROF. DR JORGE LUÍS DA SILVA GRESPAN (ORIENTADOR)

PROF. DR. ANTÔNIO RAGO FILHO (PUC-SP)

PROF. DR. JOSÉ ANTÔNIO DABDAB TRABULSI (UFMG)

PROF. DR. PEDRO PAULO A. FUNARI (UNICAMP)

PROFA. DRA. VERA LÚCIA VIEIRA (PUC - SP)

PROF. DR. FERNADO EDUARDO DE BARROS REY PUENTE

(UFMG - SUPLENTE)

PROF. DR. GIUSEPPE TOSI (UFPB - SUPLENTE)

PROF. DR. LORENZO MAMI (USP - SUPLENTE)

PROF. DR. MAURO LÚCIO LEITÃO CONDÉ (UFMG - SUPLENTE)

PROFA. DRA. MARIA APARECIDA DE PAULA RAGO (PUC-SP - SUPLENTE) 


\section{SUMÁRIO}

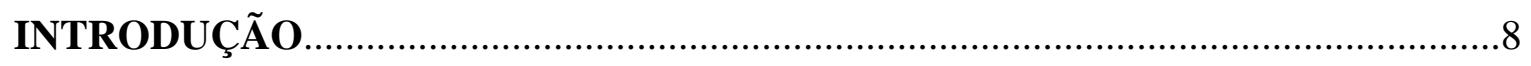

$1^{\text {a }}$ PARTE: O LIMITE COMO FORMA DE SER DA COMUNIDADE.................42

CAPÍTULO I - A EMERGÊNCIA DA PROPRIEDADE PRIVADA MÓVEL ATENIENSE: O ESCRAVO MERCADORIA …………….............................................

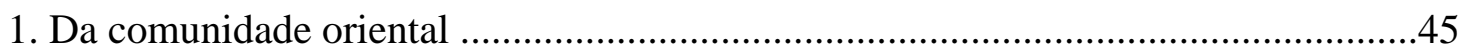

2. Da comunidade greco-romana - o oikos .................................................................48

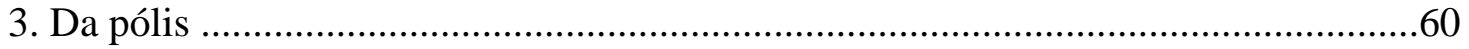

CAPÍTULO II - TELEOLOGIA E LIMITE: PÓLIS, ESCRAVO E NATUREZA ..............84

1. A inflexão da teleologia em Aristóteles …………………....................................95

2. A teleologia, a cidade e a physis .............................................................................98

3. Pólis, teleologia e escravo …………………………...............................................101

2a PARTE: LIMITE E SUBJETIVIDADE: POLÍTICA E ÉTICA................................116

CAPÍTULO I - POLÍTICA E MEDIANIA: SÓLON, PISÍSTRATO E O GOVERNO DA

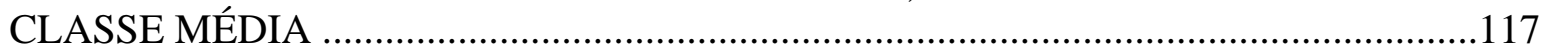

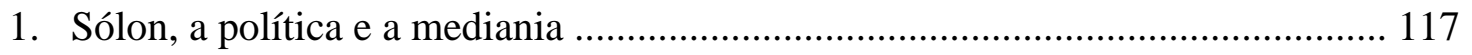

2. O tirano e a política: entre a força e a lei .................................................................127

3. Pisístrato: o tirano moderado ………………………........................................133

4. Política e limite: a constituição .........................................................................138

5. Governo da politéia: a soberania do limite. .........................................................146

CAPÍTULO II - A JUSTIÇA ENQUANTO DIMENSÃO PROFANA DA POLÍTICA..153

1. A justiça e a comunidade ......................................................................................153

2. A medida e o juiz: da justiça distributiva e da justiça corretiva ...............................167

3. Da atimia e do ostracismo: sua relação com a medida ............................................171

CAPÍTULO III - ÉTICA, LIMITE E MEDIDA................................................................184

1. A ética enquanto relação entre indivíduo e comunidade ........................................184

2. A ética e sua vocação à objetividade ....................................................................202

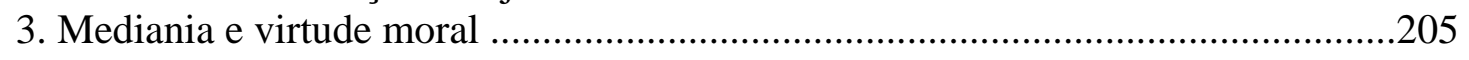

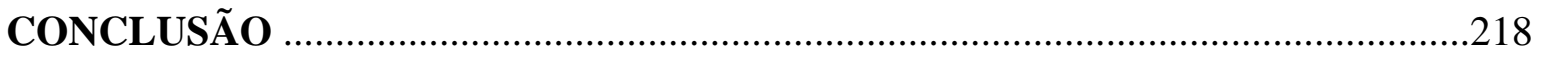

1. Pensamento e objetividade .............................................................................218

2. A Grécia clássica: entre o apogeu e o declínio ....................................................222

3. A política e a ética: mecanismos de regulação comunitária ...................................232

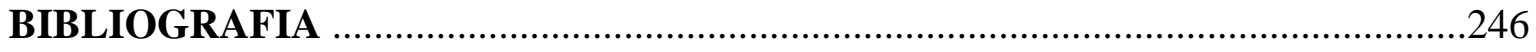




\begin{abstract}
The purpose of this work is to determine the nature, specificity and necessity of the POLITICS category in Aristotle's mature thought, having as central axis the examination of his major works: Nichomachean Ethics, Constitution of Athens and Politics. To find, therefore, the historical nexus and ties that animate and link the Stagirite's political ideology to the 4th-century BC Athenian reality, which strongly influenced the philosopher's ideological démarche. The point is to establish the links that concretely motivated the philosopher of Stagira to find in Politics and in Ethics the instruments to moderate and impose limits to the Greek way of life (the political community) and to individuality, respectively. Thus, the Aristotelian political-ethical ideology rises from the unescapable challenges of a declining Greek polis, with its innate restrictions of scarce productive forces. Such a reflection finds in the Athenian decline the motivation for its birth, that is, the Stagirite is historically driven to respond to the great challenge of his time: to recompose, within a certain degree of possibility, the city-state balance lost through decades of internal and external wars. In this way, Politics and Ethics are understood as regulative mechanisms to settle conflicts and tensions in a singular moment of Greek public life, that is, in a polis about to lose its political autonomy to Philip and Alexander. In synthesis, the aim of the Stagirite's political-ethical ideology is to intermediate relations, to limit and to equilibrate the community and its participant individual because, otherwise, the absence of limits would eventually impose (as it actually occurred) the dissolution of life in communitas.
\end{abstract}




\section{RESUMO}

O propósito deste trabalho é determinar a natureza, especificidade e necessidade da categoria da política no pensamento maduro de Aristóteles, tendo por eixo central o exame de três obras capitais: Ética Nicomaquéia, A Constituição de Atenas e Política. Estabelecer, portanto, os nexos e laços históricos que uniram e animaram o pensamento político do estagirita, relacionando-os à realidade ateniense do século do IV a.C que influenciou, sobremaneira, a démarche ideológica do filósofo em tela. Trata-se de apontar os elos que motivaram concretamente o autor a encontrar na política e na ética instrumentos a moderar, a impor limites ao modo de vida grego (à comunidade política) e à individualidade, respectivamente. O ideário político-ético aristotélico brotou dos desafios incontornáveis de uma pólis grega declinante, com suas adstringências ingênitas, de apoucadas forças produtivas. Assim, foi levado, historicamente, a responder ao grande desafio de seu tempo: recompor, a partir de certa exeqüibilidade, o equilíbrio citadino perdido por décadas de guerras internas e externas. De modo que, política e ética foram compreendidas como mecanismos reguladores a dirimir conflitos e tensões em momento singular da vida pública grega, a saber, em uma pólis prestes a perder sua autonomia política para Filipe e Alexandre. Em síntese, visava, portanto, intermediar relações, limitar e equilibrar a comunidade e o indivíduo que dela participava, pois, do contrário, a ausência de limites acabaria (como de fato ocorreu) impondo a dissolução da vida in communitas. 


\section{N T R O D U Ç Ã O}

O propósito deste trabalho é determinar a natureza, especificidade e necessidade da categoria da politicidade ${ }^{1}$ no pensamento aristotélico, tendo como eixo central o exame de três obras capitais: Ética Nicomaquéia, A Constituição de Atenas e Política² Tal proposta envolve não a obra política em seu conjunto, mas apenas os textos mais significativos que representam e sintetizam, de forma madura, as proposituras do pensar aristotélico.

Antes de adentrar em considerações pertinentes à obra aristotélica, ao exame de seus principais intérpretes, tanto no campo da filosofia como no da história, e no que concerne à forma de abordagem de seus textos e à estrutura da tese, é relevante tecer algumas considerações sobre o tempo de Aristóteles - inseri-lo, e suas idéias, na mundaneidade grega.

Aristóteles (384-322 a.C.) nasceu e viveu em tempos turbulentos, época de crise de uma formação social que há pouco mais de 150 anos vivia seu apogeu econômico, militar, cultural e político.

Atenas proporcionou ao jovem e ao velho Aristóteles não apenas a escola mais respeitada de sua época, a academia platônica; mas, de pronto, a formação social mais rica, mais complexa, na qual o multiverso social atingira máxima potencialidade. Em outras palavras, Atenas representava um modo de vida em que os gregos exercitavam suas capacidades, sua cultura nas assembléias e na discussão dos destinos da comunidade. Uma pólis mais universalmente política pela extensão da cidadania aos mais pobres, pelo surgimento da democracia que, pela primeira vez, exercitava uma racionalidade pública, que se expunha ao debate e à crítica de seus adversários. Basta citar o processo iniciado com Sólon, adensado pelas reformas de Clístenes e sintetizado por Péricles. De Sólon, temos a abolição da escravidão por dívidas do pequeno

\footnotetext{
${ }^{1}$. Expressão cunhada por José Chasin para identificar o problema político em suas amplas dimensões. J.Chasin retoma a crítica da política formulada por K.Marx, ou seja, o Estado, o poder e a política são examinados em sua determinação negativa. Ver os seguintes textos do autor: "Marx - Estatuto Ontológico e Resolução Metodológica in: Pensando com Marx, São Paulo, 1995 e Revista de Filosofia Ad Hominem, São Paulo, Tomo III - Política, 2000.

2. Doravante grafadas do seguinte modo: Ética Nicomaquéia - EN e A Constituição de Atenas - CA.
} 
camponês ateniense e a adoção de uma legislação escrita que permitiu uma certa igualdade entre cidadãos. No que tange à partilha e à distribuição da terra, Sólon não a realizou. Clístenes, por sua vez, alargou as conquistas anteriores, dando efetiva isonomia aos cidadãos, feito que, segundo historiadores, creditam a Clístenes o nascimento efetivo da cidadania ateniense. Mas é com Péricles que temos o auge da democracia ateniense e simultaneamente o início de sua decadência. Auge no que se refere à introdução da mistoforia, isto é, de uma espécie de salário que permitia ao cidadão mais pobre participar das assembléias e ser remunerado por isso. Assim, Péricles alargou substancialmente a participação das camadas mais humildes da população no cenário político. As palavras de Vidal-Naquet e Austin, em Economia e Sociedade na Grécia Antiga, ilustram bem estas considerações ao afirmarem que todos os cidadãos estão

no mesmo pé de igualdade jurídica e política /.../ em Atenas, ou se é cidadão e se participa igualmente no Estado, ou não se é, permanecendo, portanto, estranho à comunidade política, quer como homem livre (estrangeiro ou meteco) ou escravo /.../ Em Atenas, a separação entre as diferentes categorias legais é nítida: a distinção entre homem livre e escravo, bem como entre cidadão e não cidadão, é clara, e as categorias intermediárias foram eliminadas. ${ }^{3}$

Mas o auge político teve um preço econômico e, no arcontado de Péricles, temos o início da guerra do Peloponeso pela hegemonia política do Egeu. Guerra que, por vinte anos deixou seqüelas, enfraqueceu economicamente Atenas e deu início ao declínio de sua hegemonia.

Entretanto, é importante assinalar nesse passo que Atenas veio a conhecer o apogeu econômico advindo da concentração, da expansão e do fortalecimento da propriedade privada fundiária; bem como do mercado e da mão-de-obra escrava, da melhor estrutura comercial, da atividade mineira e da produção e exportação de vasos de cerâmica. Pierre Vidal-Naquet e Michel Austin, no mesmo livro, sintetizam assim a posição de Atenas,com relação ao comércio de trigo:

Na época clássica, este comércio atinge um desenvolvimento importante em numerosas cidades gregas, e, sobretudo, em Atenas, onde o crescimento considerável da cidade no século $\mathrm{V}$ teve por efeito reforçar a dependência de Atenas em relação às importações de trigo estrangeiro. /.../ A preocupação de controlar direta ou indiretamente as fontes de abastecimento de trigo é um fator

\footnotetext{
3. M. AUSTIN \& P.VIDAL-NAQUET, Economia e sociedade na Grécia antiga, p. 97.
} 
permanente da sua política. Desde o fim das guerras médicas que os atenienses tentaram novamente assegurar o controle dos estreitos conducentes ao mar Negro. Tentarão igualmente, por diversas vezes, arrancar Chipre à dominação persa, aliás, sem sucesso; além dos seus recursos em minerais (cobre), a ilha era rica em cereais. Mais tarde, cerca de meados do século, intervém para apoiar o Egito em revolta contra o Império persa: um Egito livre a aliado de Atenas teria sido de uma importância considerável para todo o seu abastecimento em trigo. Os Estados gregos tiveram, pois, uma política comercial unicamente respeitante às importações e, dentre as importações, somente àquelas que eram essenciais à existência da cidade. Nada mais interessa diretamente ao Estado, quer dizer que uma boa parte da atividade econômica terá lugar fora de qualquer intervenção do Estado, pelo menos de uma intervenção que vise encorajar ou restringir deliberadamente a vida econômica. ${ }^{4}$

O que os autores nos revelam, pois, é uma Atenas que busca a hegemonia comercial do trigo, dada a sua importância alimentar e a baixa produtividade do solo ateniense. Só uma cidade rica, com uma economia desenvolvida para a época, poderia tentar interferir nas rotas do comércio marítimo, apoiar determinados territórios em suas pretensões desde que não contrariassem os seus interesses. Outros aspectos são também evidenciados pelos autores de Economia e sociedade na Grécia antiga, acentuando o caráter singular de Atenas. Ao desdobrarem as considerações sobre a economia ateniense, explicam:

encontramos em Atenas um estado de espírito muito diferente do de Esparta no que se refere à atividade econômica em geral. Uma série de juízos aristocráticos contra o trabalho foi conscientemente combatida. Havia em Atenas uma lei atribuída a Sólon (certa ou erradamente, pouco importa: a lei existia certamente na época clássica) contra a ociosidade, forçando os cidadãos a ensinar um ofício aos seus filhos. Uma outra lei proibia censurar alguém pela sua pobreza ou pelo ofício que exercia. O exercício de um artesanato não impedia os cidadãos de deter o pleno gozo dos direitos políticos, e a assembléia incluía grande número de cidadãos artesãos lojistas, trabalhadores e comerciantes; alhures, por exemplo, em Tebas, e mais ainda em Esparta, isto teria parecido chocante. Em Atenas, o cidadão já não era obrigado a ser um proprietário rural: se, de fato, a maioria dos atenienses possuía um bem de raiz qualquer, estava feita uma inovação de princípio /.../ Mais do que isso, na Atenas do século $\mathrm{V}$, a técnica não é somente aceite, é mesmo em certa medida homenageada: para os atenienses, como para seus adversários, Atenas é a cidade da téchne por excelência. Todo este estado de espírito novo teve influência na evolução econômica da cidade: Atenas é, no século V (e continuará a sê-lo no século IV), a cidade grega mais desenvolvida do ponto de vista econômico, verdadeiro centro comercial de toda a bacia oriental do mediterrâneo /.../ Quanto à valorização da téchne, verifica- 
se que ela não abrangia igualmente todos os aspectos do técnico: a téchne celebrada pelos coríntios e pelos atenienses em Tucídedes é a téchne (naval, mais exatamente) e política. Os grandes mestres da téchne, os sofistas, limitam-se de fato a certas téchnai, em particular, a retórica e a política. O que os interessa é a arte de agir sobre os homens, não sobre a matéria. ${ }^{5}$

A despeito das contradições envolvidas no âmbito da técnica, o certo é que Atenas é, sem dúvida, centro econômico decisivo entre os séculos V e IV a.C. Os argumentos de Vidal-Naquet e Austin ilustram bem a singularidade ateniense referida, desde a extensão da categoria do cidadão aos mais pobres, como o desenvolvimento comercial que necessitava da téchne para a construção de navios apropriados ao comércio.

Não obstante, ocorre que o século IV, apesar da pujança ateniense, mostrará também suas inviabilidades, o início de seu declínio. Aristóteles, muito provavelmente, foi influenciado por este processo. De modo que vale ressaltar a inexistência no argumento aqui desenvolvido de qualquer determinismo entre formações ideais e formações sócio-históricas; não se trata, é evidente, de compreender as formações ideais como meros reflexos das condições históricas. Com o objetivo de tornar clara tal afirmação, nos limites desta Introdução, é válido utilizar a famosa passagem de $O$ Capital, em que Marx explicita as relações entre as formações ideais e a realidade histórica, ao reconhecer que Aristóteles foi o primeiro a analisar a forma do valor e sua igualdade necessária quando da permuta entre mercadorias distintas. Marx, no entanto, observa que Aristóteles concebe tal igualdade como "artifício para a necessidade prática", ou seja, Aristóteles não percebe a verdadeira natureza do valor, de como mercadorias distintas poderiam ser equivalentes ou postas num patamar de igualdade. Para Marx, tais limites da ideação aristotélica decorrem, em primeiro lugar, da própria formação social grega, notadamente do trabalho escravo que se baseava na "desigualdade entre os homens e suas forças de trabalho". Nas palavras do filósofo de O Capital:

Que na forma dos valores de mercadorias todos os trabalhos são expressos como trabalho humano igual, e, portanto, como equivalentes, não podia Aristóteles deduzir da própria forma de valor, porque a sociedade grega baseava-se no trabalho escravo e tinha, portanto, por base natural a desigualdade entre os homens e suas forças de trabalho. O segredo da expansão de valor, a igualdade e a equivalência de todos os trabalhos, porque e na medida em que são

\footnotetext{
${ }^{5}$. M. AUSTIN \& P. VIDAL-NAQUET, Economia e sociedade na Grécia antiga, p. 110-11.
} 
trabalho humano em geral, somente pode ser decifrado quando o conceito de igualdade humana já possui a consciência de um preconceito popular. Mas isso só é possível numa sociedade na qual a forma mercadoria é a forma geral do produto do trabalho, por conseguinte também a relação das pessoas umas com as outras enquanto possuidoras de mercadorias é a relação social dominante. O gênio de Aristóteles resplandece justamente em que ele descobre uma relação de igualdade na expressão de valor das mercadorias. Somente as limitações históricas da sociedade, na qual ele viveu, o impediram de descobrir em que consiste "em verdade" essa relação de igualdade. ${ }^{6}$

Na esteira da configuração dos limites sócio-históricos e de suas influências sobre as possibilidades do pensamento em seu movimento de apreensão dos nexos reais, E. Vaisman enriquece nossas considerações, no rastro do pensamento marxiano, ao apontar que:

a dimensão fundamental da determinação social do pensamento, ao contrário do que é genericamente suposto, diz respeito à sociabilidade como condição de possibilidade do pensamento. A consciência é reconhecida como consciência do ser social, como seu atributo e só enquanto tal pode se realizar. Assim, a sociedade fornece a matéria, os meios e as próprias demandas para a exercitação do pensamento, pois, da situação mais corriqueira à mais técnica ou sofisticada, é sempre como ser social que o homem pensa. ${ }^{7}$

Dito isso, voltemos ao argumento anterior. Talvez o ponto de clivagem que demonstre os influxos contraditórios da formação social grega, a partir do século IV, esteja na exasperação da guerra em seu uso político. Naquet e Austin, assim dispõem:

O que caracteriza o século IV é, antes de mais nada, a guerra. O estado de guerra torna-se quase permanente. De 431 a 338, isto é, durante perto de um século, o mundo grego conheceu quase permanentemente a guerra generalizada, sem falar, é claro, de inúmeros conflitos localizados. As causas deste estado de guerra são múltiplas. Em primeiro lugar, há que citar a falência do imperialismo hegemônico, que havia triunfado no século V. ${ }^{8}$

Aspecto esclarecido, deve ser ressaltado, em primeiro lugar, o fato de que boa parte da vida de Aristóteles é vivida no interior das guerras entre 431 e 338 a.C.,ou seja, em uma pólis que perdeu os ideais de construção do homem na e pela cidadania. Por

\footnotetext{
${ }^{6}$. K. MARX, O Capital, p. 62.

7. E.VAISMAN, A Usina Onto-Societária do Pensamento, in: Rev. Ad Hominem, Santo André, Tomo I, p.286, 1999.

${ }^{8}$. M. AUSTIN e P.VIDAL-NAQUET, Economia e sociedade na Grécia antiga, p. 132.
} 
isso, se a política é a construção racional das possibilidades humanas, os tempos de Aristóteles parecem desmentir todos os propósitos da comunidade grega, isto é, temos claramente um choque entre as proposituras ideais dos gregos e sua efetivação na vida real. Torna-se claro que, Aristóteles é marcado pelo legado de uma pólis que começara a entrar em crise já no século VI, com Sólon, mas que se recupera e triunfa com Péricles, sem ter vivido, porém, o esplendor efetivo de uma comunidade autárquica, do bem viver e da amizade. A propósito, vale ainda dispor da palavra de Vidal-Naquet e Austin:

\begin{abstract}
A história da cidade grega é, poderia dizer-se, a história de um ideal impossível que quase nunca foi realizado, a não ser imperfeitamente e por um curto período. A cidade visava assegurar a existência dos seus membros. Supunha para isso a concórdia entre os cidadãos (e a ausência de desigualdades econômicas demasiado grandes), a autarcia econômica e a independência política e militar. Entre o ideal e a realidade houve freqüentemente, mesmo na época clássica, uma certa distância. O equilíbrio interno era freqüentemente rompido por conflitos sociais e políticos, a autarcia econômica era difícil de se realizar plenamente, sobretudo para as cidades mais importantes, nomeadamente para o trigo e os metais, e a autonomia política era regularmente ameaçada, não só por potências estrangeiras (a Pérsia, a Macedônia), mas por outras cidades gregas com ambições hegemônicas, como Atenas no século V. No século IV, a distância entre o ideal e a realidade vai se tornando maior. ${ }^{9}$
\end{abstract}

A citação acima é fundamental para que se possa entrever o hiato existente entre os propósitos da reflexão política grega, de um lado, e a realidade histórica propriamente dita, de outro. De fato, em tempo algum a política alcançou ser socialmente resolvente. Nesse sentido, Aristóteles, no Livro III [1278 b] em Política, parece desabafar, ao reconhecer que já em seu tempo os governantes manifestavam interesses predominantes por questões privadas, por seus cargos e pelos benefícios que poderiam obter em tais circunstâncias. Em verdade, a filosofia e a história sempre viveram um descompasso real, contradições insolúveis desde o século V a.C. A este respeito, é relevante tomar o argumento de Francis Wolff, em Aristóteles e a Política:

a idade do ouro da pólis é o século V; a da filosofia, é o século IV. A política, no sentido de vida sob o teto da pólis, portanto, não coincide exatamente com a política, no sentido de reflexão sobre a pólis /.../ Em Atenas, no século V, desconfia-se das especulações teóricas dos 'filósofos' sobre a Natureza e sobre o Ser, e o primeiro filósofo da cidade, Sócrates foi condenado por ela à

\footnotetext{
${ }^{9}$. M. AUSTIN \& P. VIDAL-NAQUET, Economia e sociedade na Grécia antiga, p. 131.
} 
morte. Tudo se passa como se, na idade clássica da cidade, as exigências da política se opusessem às da filosofia. A preservação da cidade não requer outra especulação além dos velhos princípios de uma moral pragmática, e, por conseguinte, proíbe a do 'livre-pensador', o filósofo: pensar demais os deuses da cidade o proíbem; pensar bem demais é uma ameaça para o equilíbrio entre cidadãos (veja-se a instituição do ostracismo); pensar diferente demais, é uma ameaça para a harmonia da cidade (vejam-se os numerosos processos 'antiintelectuais' do século V). Os poucos pensadores políticos do século, como Protágoras, são 'estrangeiros' em Atenas, onde são perseguidos e indiciados por 'impiedade'; como também o são alguns filósofos da natureza, que, a exemplo de Anaxágoras, tentam fazer carreira em Atenas. Com Sócrates, num certo sentido, tudo muda, e, num outro sentido, a contradição filosofia-política torna-se extrema. $^{10}$

As considerações de Wolff ilustram com clareza a herança da qual Aristóteles é tributário. Sólon representa, no século VI a.C, o início da crise da pólis ateniense marcada pelos dilemas da partilha da terra, das condições de extrema pobreza em que viviam milhares de camponeses. Vale observar que a comunidade política não resistiu, desde o seu nascimento, mais de um século, sem se consumar em crises de grandes proporções. De seu início, por volta do século VII, ao século VI, a nova formação social, em cem anos, mostrou suas ingênitas fragilidades, suas contradições e limites. De modo mais concreto e desdobrado: de Sólon a Péricles, passando por Pisístrato e Clístenes, o fato é que Atenas transita, por inúmeros influxos, das aristocracias e tiranias para a democracia. O fio condutor de tal processo tem início nas crises camponesas do século VI, na luta pela terra, com Sólon; acirra-se com Pisístrato na medida em que Sólon não encontra solução para os problemas agrários, e adquirem um contorno diferente com Péricles, posta a extensão da cidadania, lógica que permite ao cidadão exercer outra atividade além do cultivo da terra. Então, ao lado dos dramas econômicos, e talvez por isso mesmo, as contradições da cidade se tornam evidentes, como enfoca Wolff. O ponto central de suas ponderações, importa salientar, recai sobre a impossibilidade da convivência entre a ordem da cidade, da política e sua crítica ideal, a filosofia. O texto de Wolff sinaliza que o apogeu político ateniense é, simultaneamente, a mordaça e a morte para a filosofia e os filósofos. Momento em que o Estado ataca as liberdades e se insurge contra aqueles que, de modo mais ou menos contundente, explicitam seus erros e sua intolerância. De modo que, desde o seu nascedouro, a política expõe, a impossibilidade de efetivação daquilo que os gregos tão apaixonadamente defenderam. O que irrompe, portanto, é um Aristóteles herdeiro de

\footnotetext{
${ }^{10}$. Francis WOLFF, Aristóteles e a Política, p.15-6.
} 
um passado que já não mais existe: sua vida é acompanhada de um lento, mas agressivo processo agonizante da comunidade. Esta perdeu a medida e encontrou na intensificação da guerra seu modo de ser. Logo, é efetivamente legítimo inquirir: até que ponto a política e a ética aristotélicas não representam os meios, os instrumentos de reforma e reordenação de uma formação social em declínio, impondo-lhe uma justa medida? Não será este, então, o sentido do resgate de Sólon e de Péricles? O que parece, é que Aristóteles olha para o passado, com a angústia de querer repô-lo na ordem do dia, apercebendo-se, contudo, que é um propósito praticamente impossível.

Num cenário marcado pela guerra é compreensível, que, desde o início, a obra aristotélica fosse marcada pela reflexão política, pela urgência de se encontrar novas formas de convivência na pólis, de reencontrar os velhos e bons ideais perdidos. Por outro lado, a própria Política, obra da maturidade, ao adensar suas formulações sobre o tema, ao expor suas preocupações ao final da vida, evidencia, de fato, que o tema político matrizara sua vida, porquanto inicia e encerra as reflexões construídas no curso dos tempos.

Passemos, agora, às considerações de seus comentadores.

No capítulo dedicado ao pensamento político de Aristóteles, em texto consagrado pela crítica, W.Jaeger afirma em tom pesaroso:

Se possuíssemos os escritos que os antigos conheciam, teríamos um quadro do desenvolvimento político de Aristóteles desde a academia até sua velhice. A série começa com os dois livros sobre o Político, inspirados na obra platônica do mesmo nome, e os quatro grandes volumes $D a$ Justiça. $^{11}$

O tom é justificável, pois inúmeros escritos da fase juvenil ${ }^{12}$ se perderam, restando, em alguns casos, apenas capítulos ou fragmentos relativamente extensos, por vezes obscuros, dos propósitos aristotélicos. De tal lacuna é possível inferir, segundo Jaeger, a influência inicial do platonismo, notadamente na redação sob forma de diálogos e de temas afins com Platão. Para Jaeger, trata-se de um Aristóteles ainda platônico que, progressivamente se afasta de seu mestre, num processo longo rumo ao aristotelismo.

\footnotetext{
11. W.JAEGER, Aristóteles, p. 298.

${ }^{12}$. Os escritos juvenis são da época da Academia de Platão, a partir de 367 a.C.
} 
Em textos mais recentes, como os de P.Aubenque e Ágnes Heller, Aristóteles comparece não apenas como herdeiro mais ou menos distante de Platão, mas desde logo, como pensador original. Assim, Heller em seu Aristóteles e o Mundo Antigo, afirma:

O giro radical em que se baseia toda sua ética, Aristóteles já realizara em sua Grande Ética, na Ética Eudemia e na Retórica. Este giro não é senão uma ruptura definitiva com a transcendência na ética. 'Temos de falar, pois [...] do bem: mas não do bem em geral, mas do bem em relação a nós'. Assim começa Aristóteles suas argumentações na Grande Ética. ${ }^{13}$

Para Heller, o defeito capital de Jaeger se manifesta na análise dos textos juvenis, numa "particular predileção por tudo o que procede da influência platônica"14 ${ }^{14}$ omitindo, em muitos casos, "as características novas, especificamente aristotélicas" ${ }^{15}$. Segundo Heller, Jaeger aproxima desmesuradamente "o jovem Aristóteles de Platão muito mais do que as provas o permitem" ${ }^{16}$. Essa mesma tônica já estava presente vinte anos antes em A Prudência em Aristóteles, em que Aubenque censura enfaticamente Jaeger em seus propósitos de colar Aristóteles a Platão. Assim, após tecer uma série de críticas à tese de Jaeger sobre o conceito de prudência em Aristóteles, afirma que W. Jaeger substitui

o problema da interpretação da ética aristotélica no conjunto da especulação aristotélica pelo do lugar da Ética Nicomaquéia na história da ética aristotélica e, de modo mais geral, do lugar da ética aristotélica na história da ética. À compreensão, por assim dizer, horizontal, que multiplica as conexões com outras partes do sistema, preferiu-se a compreensão vertical dos diferentes momentos na história de uma noção ou de um problema: o resultado é que vendo no aristotelismo uma simples etapa entre o pré-aristotelismo do jovem Aristóteles e o pósaristotelismo dos epígonos, termina-se por esquecer o que há de específico no próprio aristotelismo. $^{17}$

\footnotetext{
${ }^{13}$. A. HELLER, Aristóteles y el Mundo Antiguo, p. 195-6.

14. A. HELLER, Aristóteles y el mundo antiguo, p. 183.

15. Ibid., p. 183.

16.Ibid., p. 183.

17. P.AUBENQUE, A prudência em Aristóteles, p.41-50.
} 
De modo que Aubenque vê limites na interpretação que não põe em evidência o próprio aristotelismo. Aristotelismo que, para Aubenque, deita raízes na cultura préplatônica, nas tragédias gregas, fazendo com que Aristóteles se converta em filósofo da tradição, autêntico grego, recuperando raízes rejeitadas por Platão. Eis, aqui, o oceano que se desenha ao buscar as origens do pensamento aristotélico, de suas reais e efetivas relações com Platão, de sua originalidade e propósitos. Querelas à parte, o fato é que delinear a formação do pensamento político aristotélico é tarefa ingrata, para não dizer quase impossível, dadas as especificidades dos textos juvenis. Em verdade, tal esforço exigiria um estudo pormenorizado, de cunho quase filológico, que assim confrontasse os textos, entendendo ou buscando desfazer equívocos e confusões analíticas.

No que tange aos textos de maturidade ${ }^{18}$, talvez ocorra o questionamento do recorte proposto. Em primeiro lugar, tal recorte se sustenta a partir da admissão, sem reparos, pelos intérpretes, da unidade, importância e coerência das obras citadas na formação do pensamento politicamente maduro de Aristóteles. Como referência inicial, tomem-se as palavras de Francis Wolff em Aristóteles e a Política:

A conduta dos indivíduos constitui a matéria-prima da ética, e a história das cidades com seus regimes constitui a da política. De uma para outra, há múltiplos laços, com sentido duplo: a política continua sendo, para Aristóteles - é ao menos o que ele afirma no início de sua Ética -, a suprema ciência, da qual dependem o estudo e a efetivação do 'soberano bem'; o homem só pode realizar sua natureza de homem na e pela cidade. Inversamente, a cidade, quando digna desse nome, tem uma finalidade altamente moral, como Aristóteles não pára de repetir na Política. ${ }^{19}$

Wolff afirma os laços inseparáveis e notoriamente conhecidos entre política e ética, da pólis desenvolvida em oposição aos povos bárbaros. O que Wolff expressou é o espírito de uma época, sua demanda fundamental, sua identidade no fazer-se homem em comunidade.

O que ninguém esperava, contudo, é que tal demanda, já entre os gregos, mostrasse seus limites, o divórcio, mesmo não consentido, entre política e moral, como atestam in limine as palavras do estagirita na Política, III, [1278 b]:

\footnotetext{
${ }^{18}$. Textos políticos que correspondem aos últimos 12 anos de atividade intelectual de Aristóteles: são desse período A Constituição de Atenas, Ética Nicomaquéia e Política, em ordem cronológica.

19. Francis WOLFF, Aristóteles e a Política, p. 20.
} 
quando o Estado é fundado sobre a igualdade, quer dizer, sobre a similitude entre os cidadãos, estes estimam ser justo exercer a autoridade cada um a seu turno; na época antiga como é natural eles consideram justo desempenhar seu cargo tendo, em vista, o zelo pelo interesse do outro; da mesma forma que o outro, quando do exercício do cargo, se preocupava com o interesse daquele. Mas, atualmente, por causa das vantagens que se retira da riqueza pública e do exercício das magistraturas, os homens desejam conservar seus cargos, como se o poder mantivesse, para sempre, em boa forma os governantes. ${ }^{20}$

Aqui não é o lugar e nem é nosso intuito desenvolver tais comentários, mas apenas identificar o denominador comum de tais obras: encontrar a forma política mais adequada para o bem viver, para o exercício da cidadania. Nesse sentido, reverso de suas mais íntimas aspirações, Aristóteles percebe que parte dos propósitos gregos se viram, no mínimo, frustrados frente o fervor e a paixão com que foram expostos, abordados, investigados e postos à prova. A tarefa colossal de se engendrar um padrão político que estimule e preserve a convivência comunitária é, em síntese, o mote que povoa e instiga as páginas da EN e da Política, desafios de um tempo que se viram impossibilitados, emagrecidos ou mesmo abortados pelas inviabilidades da comunidade grega.

Quando da redação da $E N$, Aristóteles já havia escrito o volumoso trabalho de observação histórica e reflexão política que se objetivou pelo exame de 158 constituições gregas. Sua importância é tão evidente que o filósofo, nas derradeiras linhas do livro X da EN [1181 b], ao comentar os propósitos de um estudo que desembocaria na Política, cita o material:

nossos predecessores negligenciaram examinar o domínio da legislação. Talvez seja melhor mirar nossa atenção para tais questões e estendê-las à ciência do governo em geral a fim de dar, tanto quanto podemos, sua forma final à filosofia humana. Inicialmente, nosso esforço é o de completar tudo aquilo que se disse de maneira satisfatória, embora fragmentária por nossos predecessores; em seguida reuniremos as diferentes constituições, e depois examinaremos as condições favoráveis ou desfavoráveis dos Estados em geral, e as formas particulares de governo, como também as razões que propiciam ou não a boa administração dos Estados. Estas considerações permitirão discernir o melhor governo, as instituições, as leis e os meios que asseguram esta superioridade. $^{21}$

20. ARISTOTE, Politique, Livre III, p. 66-7.

21. IDEM, Éthique de Nicomaque, p. 320. 
Traços destes estudos aparecem, de forma parcial, nos chamados livros históricos da Política, nos quais Aristóteles examina as formas existentes de constituição. Temos, então, um amálgama de aquisições que interagem entre si. Portanto, a EN termina por onde começam as reflexões da Política, das formas de Estado, das constituições, da crítica de seus predecessores. As 158 constituições permitem a Aristóteles examinar empiricamente a política real, seus problemas, isto é, sair da pura especulação, do estado ideal, e trabalhar a política dentro de suas possibilidades de efetivação: o estado possível, no interior do bem possível. O lamentável é que determinadas partes constitutivas da Política ganhariam ordem e efetivo entendimento no confronto explícito com as 158 constituições que forneceram a base real de inúmeras ponderações do estagirita. O tamanho da perda só fica patente, quando se percebe que a CA, único documento vivo de um conjunto de 158 constituições, versa sobre a diversidade das constituições atenienses, sua história e seus principais políticos. Nesta, temos um Aristóteles preocupado não apenas em reafirmar categoricamente suas idéias, mas também em expor a história de seu tempo, das transformações políticas que se originaram a partir das aristocracias, das tiranias e do nascimento da democracia. Temos, pois, num primeiro momento, o perfil unitário que articula a EN, a Política e as 158 constituições. Tal perfil ganha força e expressão quando se revela, ainda, a intrínseca unidade no campo temático e categorial.

Do ponto de vista temático, temos o homem no singular e plural, vale dizer, do indivíduo moral que ganha corpo e sentido na e pela vida em comunidade e, inversamente, só as boas constituições organizam e ordenam a melhor forma de viver, o que pressupõe moralidade. Em seguida, avulta a centralidade da categoria do limite, notadamente na expressão da mediania, do justo-meio, da medida. Em CA, EN e Política, tal categoria percorre os poros do legislador Sólon, da virtude moral e da politéia, respectivamente. A mediania estrutura o pensamento do autor, organiza e irradia os nódulos centrais de sua démarche política. Desdobremos então, em alguns aspectos, tal problemática, e tomemos, no intento de refletir sobre o tema, a palavra de importantes intérpretes de Aristóteles. Com o que, ademais, se justifica nossa inclinação teórica por alguns comentadores, a partir e com os quais urdimos o estudo.

Como expressão das inquietudes e propósitos da construção do homem grego, do realizar-se enquanto ser da comunidade, o limite e a mediania assumem um papel ativo e central na cultura grega. A mediania, longe de estar confinada à dimensão reflexiva, puramente ideal, adentra no plano do multiverso sensível, do ser precisamente 
assim da comunidade grega, e, como em uma ramificação infinita, assume a identidade dos mais variados níveis de existência social da época. Dito diversamente, em Aristóteles, a mediania assume a forma da melhor constituição, do justo valor moral, da justiça, do dinheiro, da riqueza. Assim, a não apreensão e o próprio desconhecimento de tal especificidade, induz um número significativo de intérpretes a tomar a mediania em seu caráter puramente semântico, em sua significação categorial abstrata: enquanto, pois, moderação entre extremos, o que naturalmente empobrece e até mesmo obstaculiza o real entendimento desta categoria e de suas implicações sociais e teóricas aludidas.

Para Jean Aubonnet em longa e laboriosa introdução à sua tradução da Política, na qual são examinadas, além desta, a $C A$ e a $E N$, a mediania comparece como momento já inserido na juventude de Aristóteles, mais precisamente no seio familiar, na figura de seu pai, que o teria introduzido nos escritos de Hipócrates. Aubonnet afirma que:

Nicômaco, pai de Aristóteles, como todo médico da corporação dos Asclepíades, teve talvez o tempo de iniciar seu filho nas técnicas de sua arte e lhe fez conhecer os escritos de Hipócrates /.../ Esta iniciação médica pode ter imprimido às obras do filósofo uma tendência particular que se manifesta na Política por inúmeras comparações entre a arte do homem de Estado e aquela do bom médico; a partir de um "exame clínico" das diversas constituições, Aristóteles - como um prático - sugere uma terapêutica e remédios para suas debilidades e para seus problemas; assim como a medicina, como um todo, se baseia na proporção, na simetria, do mesmo modo que as diversas partes do Estado, a saúde, com efeito, não é senão um estado de equilíbrio /.../ entre dois extremos, entre dois excessos. Assim, esta doutrina do justo-meio deriva - sem a menor dúvida da concepção médica da saúde já exposta por Platão em o Timeo. ${ }^{22}$

A afirmação de um empirismo de talhe hipocrático ou a subsunção ideal a Platão, como gênese da mediania em Aristóteles é lacunar, pois torna rarefeito ou irrelevante o multiverso histórico que engendrou, no dia a dia, o exercício da mediania no mundo grego. A falha capital de Aubonnet, parece válido afirmar, é sucumbir ao universo puramente pragmático de uma téchne médica, herdada de seu pai, sem se indagar por que tal téchne se pôs desta forma e o que ela representa no universo grego. Por outro lado, e este argumento é igualmente enérgico, a dimensão puramente teórica advinda de Platão não explica como uma categoria poderia se tornar tão central num autor, isto é, a que necessidades sociais ela corresponde? Falta, importa salientar, a 
presença da comunidade grega, dos desafios gregos, que fizeram da mediania problema central não só de Aristóteles, mas de toda a cultura grega. Ademais, Aubonnet, no trecho acima, não refere que em $E N$ a questão da mediania comparece em semelhante equação, evidenciando que a unidade entre a arte da medicina e a política é insuficiente como explicação de um tema que já havia percorrido escritos anteriores, visto que antes de redigir a Política, Aristóteles já havia escrito a $E N$ cujo alicerce é a própria categoria da mediania, como se vê no livro II, [1104 a]:

o excesso ou insuficiência de bebida e de alimento comprometem a boa saúde, assim como a medida, nestes casos, cria, desenvolve e salvaguarda a saúde. ${ }^{23}$

O que se apresenta, assim, até o momento, e não parece desmedido ou precipitado salientar, é a universalidade teórica do justo-meio que nasce da pena aristotélica nas obras examinadas. Constata-se que a mediania acaba assumindo, ou mais propriamente, pondo-se como categoria torneadora da política, da ética, da vida comunitária, ganhando a cada momento uma face particular. Vejamos, não obstante, como um autor similar a Aubonnet, também não alcança suficiência analítica em relação à categoria da mediania.

Intérprete consagrado, autor do livro Aristóteles, em texto dos anos 30, W.D. Ross busca traçar a natureza da filosofia aristotélica. Nas linhas iniciais de seu prefácio, explicita claramente seus objetivos: "expor os principais elementos de sua filosofia, tal qual ela se oferece a nós em suas obras". ${ }^{24}$

No capítulo dedicado à Política, após algumas considerações sobre a estrutura da obra, enfatizando a ordem dos livros, o caráter incompleto de determinadas partes e a importância da metodologia aristotélica, Ross afirma:

Ele supõe a prioridade (em um certo sentido) do todo em relação a parte; a identidade da natureza de uma coisa com o fim para o qual ela tende; a superioridade da alma sobre o corpo; da razão sobre o desejo; a importância do limite, da moderação. ${ }^{25}$

Ora, a preocupação com a moderação e o limite é algo aludido, mas pouco desenvolvido por Ross. Além desta passagem, o autor faz menção aos tradicionais

\footnotetext{
${ }^{23}$. ARISTOTE, Éthique de Nicomaque, p.54.

${ }^{24}$. W.D.ROSS, Aristote, p.7.

${ }^{25}$. W.D.ROSS, Aristote, p.328.
} 
passos da Política na qual o limite comparece de forma relevante: em primeiro lugar, quando se caracteriza o governo da classe média como o único capaz de evitar os extremos. Em segundo lugar, quando são examinadas a dimensão da riqueza e sua necessária moderação face à virtude moral. Com respeito à classe média, Ross observa:

\footnotetext{
Vimos na Ética que a vida feliz é a vida conforme o justo-meio. Quando os dons da fortuna nos vêem em excesso ou de forma muito precária, torna-se difícil seguir a razão. Aqueles que têm forte propensão para a violência e aqueles que muito pouco se inclinam para patifaria mesquinha. Os primeiros não adquirem mesmo na escola o hábito da obediência e, por conseqüência, não podem obedecer; os outros não podem comandar e devem ser conduzidos como escravos. Assim nasce 'uma cidade de senhores e escravos, onde uns desdenham e os outros cobiçam. Feliz é, pois, a cidade que contém uma ampla proporção de cidadãos pertencentes à classe média, podendo balancear os extremos. Esta classe é a única que não cria uma coalizão de adversários; os ricos e os pobres (é ao menos o que pretende Aristóteles) confiam sempre na classe média mais facilmente do que uns em relação aos outros. ${ }^{26}$
}

O que se depreende é, portanto, a idéia central de que a riqueza excessiva ou a pobreza excessiva inviabilizam a verdadeira constituição, a boa ordem da cidade e a possibilidade do exercício da cidadania. Os extremos impedem que o indivíduo adquira capacidade moral de comandar e ser comandado, requisitos próprios do cidadão. A classe média se põe, a partir de seu caráter mediano, como único estamento capaz de contrabalançar a tensão entre ricos e pobres, de usufruir a moralidade que sabe comandar e ser comandada. O que fica patente é que Ross percebe a presença e a importância da mediania, mas não o seu caráter histórico fundante. Ross trata a mediania apenas como categoria ideal, desvinculada dos problemas da comunidade, de suas raízes profanas. Não ocorre ao autor buscar o vínculo entre a idéia de mediania e o passado e presente gregos. Não ocorre a Ross indagar o vínculo da classe média, da riqueza moderada com a formação social grega, suas necessidades e possibilidades. É como se uma idéia fosse gerada apenas das inquietações e capacidades de quem a formulou, de sua inteligência e singularidade próprias. Assim, a mediania aparece como categoria que antes se refere a um específico equilíbrio ideal e abstrato, do que a uma estrutural condição de vida que deita raízes em necessidades humanas mais profundas e vitais. Nesse sentido, Ross apenas constata o conceito de mediania em termos empíricos, e, não a natureza real de tal categoria.

\footnotetext{
${ }^{26}$.w.D.ROSS, Aristote, p.359.
} 
Páginas à frente, Ross nos remete para o mesmo universo:

Os bens em geral podem ser divididos em bens exteriores, bens do corpo e bens da alma; e o homem feliz deve possuir os três tipos de bens. Porém, eles não são equivalentes; em primeiro lugar a experiência mostra que um alto grau de virtude combinado a um conjunto moderado de bens exteriores produz uma felicidade bem maior do que os grandes bens exteriores com pouca virtude. Os bens exteriores são bons apenas quando o possuímos dentro de certos limites; para além deste limite, eles podem se tornar nocivos. ${ }^{27}$

Aqui, a categoria da mediania é identificada com a posse de bens moderados, na concepção de que o homem virtuoso é aquele que possui bens na justa medida. Ross poderia revelar não apenas a constatação empírica de que, em muitos casos, a riqueza excessiva desnatura ou desequilibra o caráter das individualidades, mas também que é a riqueza excessiva que se contrapõe ao modus vivendi grego.

O mesmo dilema se põe no capítulo dedicado à ética. Ainda que contemplando alguns traços da Ética Eudemia, o forte da caracterização pretendida recai, sobretudo, na $E N$. De modo que Ross discorre conscientemente sobre os mais variados aspectos, desde a natureza contingente das ações, das circunstâncias, da escolha, do ato voluntário e involuntário, das virtudes, da felicidade e do justo meio. Caracterização ampla que não o transporta para o enfrentamento da categoria da mediania para além de sua representação genérica, abstrata. Ao comentar a trama dos atos humanos em Aristóteles, afirma:

A primeira regra que ele coloca no que concerne aos atos é que o excesso e a falta devem ser evitados. Do mesmo modo que o excesso ou falta de exercícios, ou ainda de alimentação são igualmente nocivos ao corpo; do mesmo modo se nós acreditarmos em tudo, nos tornamos frouxos, e, se não acreditamos em nada nos tornaremos ousados e tolos, mas em nenhum destes dois casos será a coragem que se desenvolverá em nós. Os atos que realizamos quando adquirimos a virtude terão a mesma característica da moderação daqueles que terão permitido seu desenvolvimento. ${ }^{28}$

27. W.D. ROSS, Aristote, p.366.

${ }^{28}$. W. D. ROSS, Aristote, p.270. 
Mais uma vez entra em cena, então, a categoria da mediania em sua expressão moral de virtude equilibrada, que preserva ao fugir dos extremos, que clama pela moderação. Dessa forma, Ross revela a tônica aristotélica da proporcionalidade, da igualdade, do equilíbrio tão presentes nas formas da justiça. O que não irrompe, porém, é a relação entre formas da justiça e particularidade da entificação social, ou seja, Ross apenas descreve o pensamento aristotélico sobre o tema, saúda sua importância, mas não indaga o que permitiu a Aristóteles desenvolver um direito positivo que almeja construir e dar equilíbrio à comunidade. Em outros termos, Ross não relaciona o direito construtivo, o homem prudente, os sentimentos que devem ser vividos de modo adequado, o equilíbrio das leis ao homem que busca sua identidade na vida citadina, autárquica em momento inovador de sua história.

Já em tempos mais recentes, vale frisar, de novo, a presença de Pierre Aubenque com o livro A Prudência em Aristóteles. Neste, o autor examina a natureza do conceito de prudência, sua origem e desenvolvimento no pensamento aristotélico. Para tanto, Aubenque percorre o tecido da obra aristoteliana, não só consubstanciada pela Ética Eudêmia e a Magna Moralia, mas, notadamente pela EN e, complementarmente, pela Metafísica. Aubenque defende a tese de que a categoria da prudência exposta no livro VI da EN deriva da noção de contingência. Em verdade, Aristóteles teria elaborado uma cosmologia da contingência ao dissociar, na Metafísica, o mundo sublunar do mundo supralunar, o mundo da mudança e o mundo da necessidade. De sorte que Aubenque vê, na categoria da prudência, o reconhecimento aristotélico da finitude, dos limites e das possibilidades do agir num mundo incerto e imprevisível. Isto caracteriza, segundo o autor, não apenas a recusa do ideário socrático-platônico da prudência, mas, acima de tudo, a descoberta da natureza do agir humano, de sua peculiaridade, da ação que se desenvolve num universo bipolar, do indivíduo e da mundaneidade. Aubenque, enfim, vê em Aristóteles um reordenamento do problema na medida em que não "se pode falar da prudência sem se perguntar por que o homem tem de ser prudente neste mundo, prudente mais do que sábio ou simplesmente virtuoso". ${ }^{29}$ De modo que a categoria da prudência na $E N$ não significa apenas uma antítese aos exageros do platonismo, Aubenque pretende mostrar que a distância existente entre as categorias da prudência na Magna Moralia, no Protrético, na Ética Eudêmia e de sua síntese na EN é resultado do novo enfoque aristotélico, a um só 
tempo, entre mundaneidade e capacidade subjetiva. O que talvez chame mais atenção é o fato de Aubenque retornar aos clássicos da tragédia grega para colocar Aristóteles como herdeiro da prudência e da contingência trágicas. Assim, para Aubenque

sempre se viu Aristóteles à sombra de Platão, acabou-se por esquecer que ele era antes um grego, talvez mais Grego que seu mestre, mais próximo que este da prudência reverencial, verdadeira mensagem trágica da Grécia, da qual Platão acreditou enterrar os últimos escrúpulos, dissipar as últimas sombras, e que, no entanto, renasce no homem aristotélico que, num mundo dividido, não é mais dirigido pelo espetáculo de um Deus demasiado distante. ${ }^{30}$

Em contraste com uma certa historiografia ${ }^{31}$, Aubenque não pretende rastrear um possível laço evolutivo do conceito de prudência nas éticas de Aristóteles, mas, em contraposição, nos coloca diante de um Aristóteles com raízes profundas na cultura grega, que recupera na origem um conceito secular. O que resulta positivo, para nossas considerações, é que Aubenque, ao fazer isso, ressalta em termos mais substantivos, em face de intérpretes precedentes, as dimensões de limite, mediania e prudência. Mesmo que Aubenque pouco evidencie as particularidades históricas de tais movimentos ideais, seu reforço e seu adensamento destas categorias vai ao encontro de nossos propósitos de pesquisa. Em suma, Aubenque alcança expor alguns nervos vitais de tais conceitos, conquanto não os insira no movimento histórico que os motivou e engendrou. De qualquer modo, é enfático ao afirmar que a "idéia de limite" ${ }^{32}$ é

um dos traços mais constantes do espírito grego. Um bom exemplo do entrelaçamento desses temas é fornecido por listas, a metade legendária, sem dúvida, de preceitos atribuídos pela tradição aos Sete Sábios da Grécia. Na lista atribuída a Demétrio de Falero, conservada por Estobeu, encontramos misturadas exortações como estas: a medida é a melhor de todas as coisas /.../ não exagerar /.../ conhece-te a ti mesmo /.../ conhece o momento oportuno /.../ ama a prudência ${ }^{33}$.

Em verdade, tal panorama traçado por Aubenque evidencia que a própria prudência se põe num contexto de limites, isto é, ser prudente significa optar pela mediania, evitar os excessos, pois, ao analisar as situações, o indivíduo percebe a marca

\footnotetext{
30. Ibid., p.54.

31 . Cf. a crítica de Aubenque a W.Jaeger no livro A prudência em Aristóteles, p.32.

32. P. AUBENQUE, op. cit., p.263.

33. P. AUBENQUE, A prudência em Aristóteles, p. 263.
} 
indelével da contingência, sua força e presença; de modo que a prudência, diante das incertezas, é canalizada para um limite seguro: o do justo-meio.

Por fim, nossa rápida digressão não poderia deixar de resvalar, uma vez mais, no importante estudo Aristóteles e o Mundo Antigo, de Ágnes Heller. De forma enfática, a filósofa reconhece a importância da categoria do justo-meio, do limite, na vida social grega. De sorte que a autora assinala como a categoria da medida tem sua origem na comunidade, afirmando:

\begin{abstract}
No princípio o conceito de medida não era ético, mas econômico /.../ o adjetivo métrios se referia unicamente à riqueza, quer dizer, ao seu uso judicioso /.../ A medida perde progressivamente seu sentido de sábia utilização da riqueza para expressar os efeitos que esta, a abundância ou o relativo caudal dos bens materiais exercem sobre a personalidade humana. ${ }^{34}$
\end{abstract}

E, acrescenta:

A 'medida' enquanto função de juiz moral se vincula à estrutura social e ideológica da Grécia, principalmente na Ática. O beco sem saída em que se encontrava a produção, influi de tal modo que a relação com o consumo se converte em problema central da atividade humana. Desse modo, a temperança acaba por tornar-se uma categoria fundamental. Assim, desde o momento em que as necessidades da produção não punham limites objetivos às possibilidades de satisfazer às necessidades humanas, a aplicação de uma medida moral, subjetiva, à satisfação das mesmas, fez-se necessária. Dissemos que este tipo de medida apareceu basicamente na Jônia, onde a riqueza econômica era considerável e onde a temperança no consumo era uma exigência maior do que em qualquer outra parte. ${ }^{35}$

O que se deve indicar in limine, postos o argumento e a argumentação em curso, é que nenhum outro estudioso foi tão significativo ao imbricar limite, mediania e atividade humana, produtiva. Heller sustenta a idéia de que o limite moral, a mediania, tem sua origem nas dimensões acanhadas da produção grega e que a mesma, dado o padrão modesto, era insuficiente para suprir as já precárias necessidades humanas. Daí, em termos estruturais, a imposição moral do limite. Talvez o que deva ser posto para além das aquisições de Heller, proposição que este estudo buscará determinar pouco a pouco e que ora apenas se esboça, é o fato de que a imposição do limite em sua expressão moral deriva da imposição do limite pela vertente política, a qual, por sua

34. A. HELLER, Aristóteles y el mundo antiguo, p. 305.

35. A. HELLER, Aristóteles y el mundo antiguo, p. 309. 
vez, reverbera e marca a dinâmica e orgânica da vida produtiva. O que vale dizer que a mediania moral é decorrente dos influxos limitadores da política, e não o contrário. Dito de outro modo, a política ordena, organiza e equilibra as possibilidades da convivência social; a moralidade, como força coadjuvante, reforça a ordenação da política no indivíduo, fortalecendo reciprocamente a ordem e o equilíbrio da comunidade. O indivíduo, portanto, no caso grego, é constrangido política e moralmente a se pôr num determinado limite, vale dizer, a aceitar o limite como virtude. A própria modernidade acentua, por vezes de forma imprópria, a tônica do império ético, do homem virtuoso, em detrimento do homem político ou público. Ou ainda, a modernidade tende a pôr em relevo o homem grego em sua acepção moral e política e não, inversamente, na acepção do indivíduo político e moral. Neste ponto, cabe a pergunta, tal ênfase não seria o caminho encontrado pela modernidade para justificar as falácias da política, do Estado, adstringindo-as ao campo moral, evitando-se assim, o exame de sua lógica e necessidade?

A seguir, e, em plena consonância com as considerações acima, deve ser posto que a primazia do político sobre a moral se expressa na distinção qualitativa que Aristóteles estabelece entre os fins da política e os fins da moral. Nas páginas iniciais da EN, I, [1094 b], Aristóteles estabelece claramente a prioridade da política sobre a ética, ao afirmar que:

\footnotetext{
Ela determina quais são as ciências indispensáveis aos Estados, fixa o que cada cidadão deve aprender e até que ponto. E não vemos, com efeito, que as ciências mais nobres se encontram sob sua dependência, por exemplo, a ciência militar, a economia e a retórica? Como a política utiliza as outras ciências práticas e, por outro lado, legisla sobre o que devemos fazer ou evitar, seu fim abarca o das demais ciências, a ponto de ser o bem supremo humano. Mesmo que o bem do indivíduo e do Estado se identifiquem, parece mais importante e mais conforme aos fins verdadeiros salvaguardar o bem do Estado. Embora seja desejável atingir este fim para o indivíduo tomado à parte, é mais nobre e divino quando o aplicamos para um povo ou Estados como um todo. ${ }^{36}$
}

O que esta reflexão demarca, então, e que é um ponto colunar para o reconhecimento da lógica do pensamento político de Aristóteles é o feitio da prevalência da comunidade sobre o indivíduo, do interesse geral sobre o particular, ou ainda, da política sobre a ética. O indivíduo e seus objetivos ganham corpo pela pólis, 
matrizados pelos influxos da mesma, de sua autarquia, do bem viver. Eis que a ética comparece aqui como coadjuvante, importante, mas balizada pela política, inserida em seus objetivos, na direção de fortalecer a comunidade que ganha ordenação por via do instrumento político. De forma que a lógica aristotélica privilegia ou se funda no plano universal, na comunidade dos homens, no animal político que sozinho ou isoladamente não é ou pode nada, mesmo que, por suposto, fosse moralmente bom. O que está em jogo, pois, é que a comunidade só pode se afirmar como construção de um trabalho comunal, imperativo da cidade, porque isoladamente a individualidade não dispõe dos meios necessários. A comunidade é entendida como verdadeira força produtiva, como a única possibilidade de se produzir em circunstâncias desfavoráveis, de subsunção do homem à natureza. A esse respeito, talvez seja esclarecedor para o tema citar, mesmo de passagem, alguns trechos das Formen ${ }^{37}$ em que Marx afirma o que se segue:

\begin{abstract}
A comunidade - como um Estado - passa a ser, por um lado, a relação recíproca entre estes proprietários privados livres e iguais, suas aliança contra o mundo exterior - e, ao mesmo tempo, sua garantia. A comunidade baseia-se, aí, no fato de seus membros serem trabalhadores proprietários, pequenos camponeses que cultivam a terra; mas igualmente, a independência destes consiste em seu mútuo relacionamento como integrantes da comunidade, na defesa do ager publicus (terra comum) para as necessidades comuns, para a glória comum, etc. Ser membro da comunidade continua sendo condição prévia para a apropriação da terra, mas, na qualidade de membro da comunidade, o indivíduo é um proprietário privado. Sua relação com sua propriedade privada é, ao mesmo tempo, uma relação com a terra e com sua existência enquanto membro da comunidade - sua manutenção como membro da comunidade significa a manutenção da própria comunidade e vice-versa. ${ }^{38}$
\end{abstract}

Em primeiro plano, aparece o proprietário da terra, o pequeno camponês como comunidade dos proprietários, livres e iguais em mútua dependência, na condição de que o proprietário individual só é proprietário pela comunidade e que sua propriedade só tem sentido se estendida à comunidade. O que se põe é que a propriedade é, neste momento, privada, mas de certo modo comunal. $\mathrm{O}$ fato é que, no baixo desenvolvimento das forças produtivas, a comunidade aparece como a única força capaz de reproduzir a comunidade, de dar aos cidadãos os bens necessários à sobrevivência, o

\footnotetext{
37. K. MARX, Formen: Formações Econômicas Pré-Capitalistas é parte integrante dos Gründrisse, estudos elaborados entre 1857-8 decisivos para a tessitura de $O$ Capital.

38. K. MARX, Formen, p. 70.
} 
que, como proprietário isolado, seria impossível dado os constrangimentos das forças produtivas. Assim,

a propriedade, portanto, significa pertencer a uma tribo (comunidade) (ter sua existência subjetiva/objetiva dentro dela) e, por meio do relacionamento desta comunidade com a terra, com seu corpo inorgânico, ocorre o relacionamento do indivíduo com a terra, com a condição externa primária da produção - porque a terra é, ao mesmo tempo, matéria-prima, instrumento de trabalho e fruto - como as pré-condições correspondentes à sua individualidade, como seu modo de existência. ${ }^{39}$

Em outras palavras, a unidade entre indivíduo e comunidade se forja nas condições onde a terra é, simultaneamente, o local onde o homem exerce o trabalho (matéria-prima), realiza o trabalho (instrumento) e colhe o seu fruto. Isto significa que a terra como centro da produção antiga, como força produtiva, gera, necessariamente, dilemas de toda ordem, desenvolvimento limitado, dentro de limites empiricamente observáveis. Daí, provavelmente, a opção aristotélica pela comunidade. O que temos é um homem com potencial finito, com horizontes finitos, com uma produção que, centrada na terra, pouco oferece em termos de desenvolvimento humano-social. Nessa mesma direção, tomando arrimo nas teses marxianas anunciadas, José Chasin afirma:

\begin{abstract}
o que agora se destaca, e ainda com palavras de Marx, é que 'o mundo antigo representa uma satisfação limitada' do homem. Um universo reduzido de formas acabadas e contornos definidos, de sendas estreitas e curtos horizontes, que nunca saem do campo visual dos agentes e delimitam suas equações teleológicas. Toda a potência humano-societária aí se resume à força coagulante das relações comunitárias, toda ela transpassada por uma lógica adstringente que enerva densa malha de resguardos estabilizadores, reiterando e multiplicando fronteiras. Donde provém a decisiva inclinação grega pela medida, ou mais precisamente pela idealizada justa-medida. Marca da sabedoria helênica, a idéia de medida traduz antes de tudo a presença e a consideração permanente dos limites - da comunidade e dos indivíduos. ${ }^{40}$
\end{abstract}

O que está posto, segundo os autores anteriormente referidos, é o horizonte delimitado pelas forças produtivas, de um homem coagido ao limite, estrangulado por suas inviabilidades. Inviabilidades que, segundo José Chasin, geram a necessidade de

\footnotetext{
39. K. MARX, Formen, p. 86.

40. J.CHASIN, O Futuro Ausente in: Ad Hominem, Revista de Filosofia, Política e Ciência da História, São Paulo, Tomo III, p.168-9, 2000.
} 
um controle "extra-social" de regulação e equilíbrio da comunidade. De sorte que nesse universo, amesquinhado em suas possibilidades, J. Chasin expõe sua hipótese:

por seus limites, debilidades e incipiências intrínsecas, a comunidade antiga [o exemplo grego é a melhor iluminura] não é socialmente auto-estável, é incapaz de se sustentar e regular exclusivamente a partir e em função de suas puras e específicas energias sociais. Esta incapacidade ou limite social engendra, a partir de si mesma, em proveito e em vista da estabilidade comunitária, uma dessubstanciação social como força extra-social - uma desnaturação e metamorfose de potência social em força política. Ou seja, esta é uma força social que se entifica pelo desgarramento do tecido societário, dilaceração naturalmente determinada pela impotência deste, e que, enquanto poder, se desenvolve tomando distância /.../ da planta humano-societária que o engendra (mesmo na democracia direta) e a ela se sobrepõe, como condição mesma para o exercício de sua função própria - regular e sustentar a regulação. ${ }^{41}$

E reitera o mesmo padrão de argumentação linhas à frente:

foi a fragilidade da comunidade antiga que fez brotar pela primeira vez a política em seu perfil mais atraente, não como produto de suas melhores qualidades, mas precisamente da pequenez de suas energias societárias ou da extensão restrita de suas grandezas intrínsecas. Encarar, em suma, que a política como fato e idealização é a filha bastarda da infância grega, ou seja, que a comunidade real, porém incipiente ou atrófica, e bastardia política formam o indissolúvel cinturão de ferro da civilização antiga. ${ }^{42}$

José Chasin nos coloca diante de uma tese que, firme-se desde já, é contrária à tradição ocidental, a qual encontra na política as melhores e mais determinantes possibilidades e qualidades humanas, seara ou mediação que se ergue em prol de um mundo mais racional, quer dizer, menos injusto e mais harmônico. O fato é que a referida tese se insinua e arma numa contra-corrente, na qual a esfera política irrompe como instância de adstringências humano-sociais, e portanto não como afirmação racional das melhores capacidades dos homens.

Enquanto para a maioria dos intérpretes da filosofia de Aristóteles é suficiente pôr em relevo as categorias centrais da política e da ética; neste estudo, entende-se ser preciso articulá-las às formações sociais gregas. De modo que é vital encontrar a unidade, o metabolismo entre objetividade e subjetividade, relação que permite

41. Ibid., p. 169-70.

42 . Ibid., p.171. 
reconhecer em termos mais abrangentes como e por que Aristóteles é levado a pensar de determinado modo.

Isto, por certo, demanda articulação entre pesquisa histórica e análise filosófica. Do que resulta, assim se crê, um estudo pautado pela análise rigorosa e historicamente fundada de um conjunto de textos examinados em sua lógica e tessitura próprias. Buscam-se, em suma, ideações que encontrem arrimo nos textos, eco real, assim como a consistência de argumentação no intuito de fundamentar nossas considerações. Isso só é possível na medida em que o trabalho adquire

compromisso com a solidez dos vigamentos que caracterizam a chamada - análise imanente ou estrutural. Esta, na melhor tradição reflexiva, encara o texto - a formação ideal - em sua consistência auto-significativa, aí compreendida toda a grade de vetores que o conformam, tanto positivos como negativos: o conjunto de suas afirmações, conexões e suficiências, como também as eventuais lacunas e incongruências que o perfaçam. Configuração esta que em si é autônoma em relação aos modos pelos quais é encarada, de frente ou por vieses, iluminada ou obscurecida no movimento de produção do para nós que é elaborado pelo investigador. ${ }^{43}$

Assim, a despeito das polêmicas em torno das formas e possibilidades de apreensão efetiva dos nódulos significativos ou da malha conceitual de um texto, nosso propósito é apreender a trama imanente dos mesmos, reconhecendo os pilares da concepção política aristotélica e sua conexão com os supostos e os destinos da comunidade grega, indagando de que maneira o período da Grécia clássica e até mesmo arcaica influenciaram substancialmente a gênese e o desenvolvimento de seu pensamento; pesquisar de forma inequívoca a relação entre história e filosofia, entre formações ideais e sociedade. Analisar significa contrapor, isto é, confrontar a história e os processos ideais, notadamente a política aristoteliana, e compreender sua lógica e necessidade. Lógica no intuito de desvelar seus nexos, necessidade na direção de perceber que tal arcabouço ideal fora matrizado pelos influxos da realidade histórica e que, nesta condição, revela-se uma exigência própria em sua natureza de ser assim e não de outro modo.

Para tanto, convergimos para alguns importantes historiadores que se inclinam para a mesma articulação. Tal material, que se toma e contextualiza, permitirá fundamentar nossas hipóteses, conectar o discurso aristotélico com as premissas sociais, criando canais de acesso às ideações políticas e morais do filósofo grego.

43. IDEM, Marx - Estatuto Ontológico e Resolução Metodológica in: Pensando com Marx, p.336. 
Tracemos, então, algumas considerações sobre os autores e suas reflexões, o que parece pertinente, visto tornar mais claro o sentido e perspectiva deste estudo.

Nossas observações começam com Jean-Pierre Vernant, historiador francês de longa e larga tradição. Em verdade, a França produziu uma gama de historiadores que influenciaram decisivamente os estudos gregos no século XX. Alguns nomes bastam para ilustrar: Claude Mossé, Pierre Vidal-Naquet e Yvon Garlan, entre outros.

Em O Homem Grego, organizado por Jean-Pierre Vernant, encontramos um conjunto de textos que buscam configurar um perfil do homem grego desde a vida privada até a vida pública e militar. Trata-se de uma síntese dos mais variados aspectos da vida grega, de seus valores, crenças, modos de vida. Texto importante não por esgotar os temas, mas, acima de tudo, por trazer à tona um manancial expressivo de informações. $\mathrm{O}$ livro abre com um ensaio que leva seu nome: O Homem Grego. Nele, Pierre-Vernant esboça, inicialmente, a dificuldade de se falar do homem grego, pois, na realidade, de que homem grego se fala? Do de Atenas, Esparta ou Estagira? E de que prisma político se fala? Do homem monárquico, aristocrático ou democrático? Do homem da época arcaica ou clássica? Ao reconhecer tais dificuldades, Vernant assinala o problema central de toda pesquisa histórica sobre a Grécia: o da escassez e autenticidade das fontes. Daí a expressão atenocentrismo para designar a pesquisa histórica centrada no homem ateniense. Não obstante, embora os limites sejam evidentes, a pesquisa histórica nunca deixou de dar os contornos específicos, as qualidades distintas da formação social grega e, simultaneamente, da singularidade do homem grego no universo antigo. De sorte que o artigo de Vernant é um ensaio denso, que problematiza as fontes e desenha o perfil de um homem que, em sua tipicidade, é marca indelével de um tempo.

Em O Homem Grego, dentre as inúmeras ponderações de Vernant, avulta, com interesse, a distinção fundamental que contrapõe homens e deuses. A questão é posta pelo o autor da seguinte forma:

Do indivíduo grego podemos dizer que de forma menos reflexiva e teórica, também era espontaneamente cósmico. Cósmico não significa perdido, imerso no universo; no entanto, esta implicação do sujeito humano no mundo supõe, para o indivíduo, uma particular forma de relação consigo mesmo e de relação com o outro. A máxima de Delfos 'Conhece-te a ti mesmo' não preconiza, como tenderíamos a supor, um voltar-se sobre si mesmo para alcançar, mediante introspecção e auto-análise, um 'eu' escondido, invisível para qualquer outro e que se colocaria como um puro ato de pensamento ou como o âmbito secreto da intimidade pessoal /.../ Para o 
oráculo, 'Conhece-te a ti mesmo' significa conhece teus limites, sabe-te como homem mortal, não intentes igualar-se com os deuses. ${ }^{44}$

O que Vernant coloca, para além de qualquer reducionismo de fundo psicológico, é o fato de que existe um limite entre homens e deuses, uma fronteira reconhecida pelo homem e, nesse sentido, consciente para si mesmo. O homem grego se percebe, se reconhece, dentro de suas possibilidades, de sua vida comunitária, como aquele que luta contra a morte, contra a velhice, contra a feiúra, contra a doença, contra a contingência. A existência do divino é, portanto, a projeção do próprio homem na direção de que os limites sejam superados ou, no mínimo, que seus efeitos sejam minimizados. É difícil lidar com a feiúra, a doença, a velhice, a morte, a contingência. É notório que a contingência traduz um homem que não sabe ou ainda não pode lidar com as adversidades, com os acasos, com aquilo que pode ser diferente, que foge, que escapa às suas capacidades, aos seus intentos como animal político podendo, nesse sentido, arrastar para o desfiladeiro os indivíduos e a própria comunidade. De sorte que - e o contexto argumentativo arrima esta generalização - a contingência parece ser um estorvo para os gregos, algo imponderável que escapa aos lineamentos mais ou menos racionais que a própria subjetividade reconhece na cotidianidade. Em outros termos, ao se reconhecer como finito, limitado diante dos deuses, o homem grego percebe, de alguma forma, os próprios limites de sua comunidade, de uma comunidade que ainda não é capaz de transpor, mesmo que de forma incipiente, os desafios postos pela própria natureza.

P. Aubenque sinaliza na mesma direção, quando afirma:

O 'conhece-te a ti mesmo' não nos convida a encontrar em nós o fundamento de todas as coisas, mas, ao contrário, traz à consciência nossa finitude: é a fórmula mais expressiva da prudência grega, ou seja, da sabedoria dos limites. Na realidade, Sócrates foi o primeiro a desconfiar do conhecimento de si, a não ser esperar dele o reconhecimento do que é apropriado à nossa condição mortal. Platão não diz outra coisa ao interpretar a fórmula délfica, malgrado os contrasensos que já se cometeu contra ela, como um convite à medida. ${ }^{45}$

Com fórmulas similares, Vernant e Aubenque sinalizam para os problemas de uma vivência comunal, de um mundo contingente oposto ao mundo das divindades, de

\footnotetext{
${ }^{44}$. J.P VERNANT, El hombre griego in: El hombre griego-coletânea organizada por J.P.Vernant, p. 26.

${ }^{45}$. P.AUBENQUE, A prudência em Aristóteles, p. 264.
} 
um mundo no qual os homens pagam o preço de seu não determinismo. Mas, conhecer os próprios limites, ao inverso do que possa parecer, é antes de mais nada a própria condição dos homens, condição de ser humano, de se fazer homem na e pela comunidade. Antes de ser um mal em si, a contingência é passo decisivo para a humanização, num processo que, ao contrário dos deuses, é infinito em suas possibilidades e em seus objetivos. Com os deuses eu já sei o que sou e como sou; com os homens eu descubro paulatinamente o que sou, como sou e o que poderei ser; assim, a incerteza e contingência jogam a favor dos homens. Em suma, assinala-se com vigor o reconhecimento da dimensão do limite; no caso, a partir dos limites que separam homens e deuses. Nesse sentido, o homem se identifica, como homem, pela internação dos limites, pela distância face aos deuses, pelas capacidades distintas. Vislumbra-se, então, a identidade humana no limite, filha das capacidades finitas, de um mundo social finito. Mas Vernant, do mesmo modo que outros teóricos, não questiona os fundamentos mais substantivos, históricos do limite; revelando, em última instância, sua existência genérica no interior da formação do homem grego.

Outro texto relevante é o de Yvon Garlan. Em seu artigo, O Militar, o autor discute o estatuto do militar na ordem social grega, sua particularidade nos diversos regimes, seu ofício e valores. Texto importante que põe em relevo um dos traços característicos das sociedades escravistas: sua propensão para a guerra. Garlan, ao citar Platão e Aristóteles, observa que a guerra faz parte do processo de acumulação de riquezas, tanto de bens materiais, como de escravos. Em suas palavras:

Platão e Aristóteles não excluíram a guerra (tampouco a escravidão) de seus respectivos projetos de sociedades ideais, e não puderam, por isso mesmo, evitar a explicação de sua existência. As respostas que dão são convergentes e possuem uma aparente simplicidade: a causa da guerra seria o desejo de 'ter mais', de adquirir, segundo o primeiro, riquezas e eventualmente escravos; para o segundo, escravos sobretudo /.../ Entendo que as palavras 'riquezas' e 'escravos' podem ter um sentido mais ou menos metafórico. Porém, isto não modifica em nada a perspectiva global de nossos filósofos: a guerra é essencialmente considerada por eles como a arte de adquirir, pela força, suplementos para viver, sob a forma de subsistência, de dinheiro ou de agentes de produção; como a paz é a arte de desfrutar de tudo isto. ${ }^{46}$

Independentemente de Garlan considerar as palavras riqueza e escravo como metáforas, o fato é que sua reflexão, remetendo a Platão e a Aristóteles, põe o acento na

\footnotetext{
${ }^{46}$. Y. GARLAN, El Militar in: El Hombre Griego - coletânea organizada por J.P.Vernant, p.71-2
} 
questão capital: a guerra como mecanismo que visa suprir as necessidades de uma formação social que, dado o baixíssimo padrão tecnológico, é incapaz de produzir os bens necessários à sua reprodução imediata. Assim, burlar a asfixia das forças produtivas ao adentrar pela expansão e conquista territoriais é, de imediato, ofício da guerra. O acento posto por Aristóteles, mais do que Platão, na aquisição necessária de escravos, denota uma percepção aguda de sua época, isto é, o estagirita compreendia que uma maior quantidade de escravos significava, naturalmente, uma expansão de produtividade e, por conseguinte, de possibilidades de se pôr em sua tão almejada autarquia citadina. Por outro lado, as próprias condições naturais interferiam decisivamente no processo produtivo, pois, em termos geográficos, a Grécia exibia e exibe um território de escassa matéria-prima, marcado por montanhas, acidentes, com terras pouco cultiváveis. Em situações desse tipo, a natureza se converte, como correu entre os gregos, em forte obstáculo à produção para a comunidade. A tônica, e uma vez mais, converge para a fundante dimensão social do limite, não apenas das forças produtivas claudicantes, mas também da natureza pouco abundante e geograficamente adversa. Se somarmos o baixo desenvolvimento das forças produtivas e a pouca generosidade da natureza, as tendências sociais são as da guerra, não só como expansão de territórios e conquistas, mas, de pronto, como defesa do próprio território, das próprias condições de subsistência, como assinala Marx, ainda nas Formen:

A guerra é, portanto, a grande tarefa que a todos compete, o grande trabalho comunal, e se faz necessária, seja para a ocupação das condições objetivas da existência, seja para a proteção e perpetuação de tal ocupação. ${ }^{47}$

A coletânea prossegue com o texto de Giuseppe Cambiano intitulado Fazer-se Homem. Título forte, cujo objetivo é rastrear as várias dimensões da comunidade grega, evidenciar que o homem só adquire o estatuto do humano, nos e pelos poros da vida citadina. Assim, o autor põe em relevo o significado ativo da paidéia, do cotidiano grego no processo formativo do cidadão, desde a família, a efebia, o casamento e a vida política. Por outro lado, o autor também realça algumas mazelas próprias da formação grega. De sorte que Fazer-se Homem significa a compreensão de que o indivíduo é ativo e influenciado pelo tecido social, nos limites próprios de cada época.

\footnotetext{
47. K. MARX, Formen, p. 69.
} 
Logo no início de suas considerações sobre a cidade grega, Cambiano chama a atenção para o número elevado de óbitos de recém-nascidos e a prática do infanticídio:

\begin{abstract}
Naturalmente, a primeira condição era sobreviver e escapar do alto índice de mortalidade presente na Grécia antiga, causado, em primeiro lugar, por partos prematuros ou anômalos e, logo em seguida, por enfermidades derivadas de uma alimentação inadequada, de uma má higiene e, junte-se a isto, de uma terapêutica impotente de boa parte da medicina antiga. /.../ Mas não era só a natureza que atuava como sistema seletor de sobrevivência. Nascer em boas condições físicas permitia escapar à eliminação, a que não se duvidava em recorrer nos casos de deformidade, casos interpretados pelos pais e por toda a comunidade como uma espécie de castigo divino /.../ Em Esparta a decisão de que o recém-nascido poderia viver pertencia aos membros mais velhos da tribo (phylé), a qual pertencia o pai. /.../ Em Atenas e outras cidades, se recorria ao método da exposição do recém-nascido em um vaso de barro ou em outro recipiente longe de sua casa, em lugares inóspitos, fora da cidade, onde poderia morrer de fome ou ser despedaçado pelas feras, a não ser que alguém fizesse sua recolha. ${ }^{48}$
\end{abstract}

Em primeiro lugar, Cambiano nos remete a dois cenários distintos e conexos. O primeiro diz respeito à impotência grega de lidar com a mortalidade infantil, suas altas taxas em decorrência dos estreitos limites da medicina, da má alimentação, do desconhecimento de doenças e da falta de higiene. O que se depreende é um universo limitado de atuação da medicina, este, por sua vez, condicionado pelos baixos padrões de conhecimento e transformação da natureza. A própria alimentação e higiene pressupõe um elevado grau de conhecimento das leis naturais, dos mecanismos biológicos e de sua regulação. Só um patamar ainda demasiadamente circunscrito da atividade produtiva, de um conhecimento que não se fez coisa no mundo, pode levar a patamares tão extensos de mortalidade infantil. Em conexão, o infanticídio funda igualmente suas raízes neste universo circunscrito: o que significa abandonar uma criança mal formada, simples vítima dos erros da natureza? Significa livrar-se de alguém que não poderá exercer atividade alguma, principalmente o ofício político e militar no caso dos homens; significa que não será reconhecido pela tribo, despesa inútil em contexto social adstringido, adverso. Por outro lado, se for mulher, o problema se agrava na medida em que a relação do dote se inviabiliza, pois ninguém se casará com uma mulher que apresente algum tipo de anomalia. E, se ainda as crianças forem normais, mas fruto de relações ilegítimas entre cidadãos e escravos, o infanticídio pode

\footnotetext{
${ }^{48}$. G. CAMBIANO, Hacerse hombre in: El hombre griego, coletânea organizada por J.P.Vernant,p.103-4.
} 
decidir o seu futuro, pois crianças nestas circunstancias não serão reconhecidas pelo seu demos, não serão inseridas na comunidade e, nesse sentido, não terão a possibilidade da paidéia, do tornar-se homem. Os próprios limites da comunidade grega apontam para a necessidade de se legitimar as relações matrimoniais a partir do reconhecimento familiar, dos demos, com o intuito de possibilitar que as futuras crianças se tornem cidadãos no pleno direito da palavra. Cambiano, pois, nos coloca diante de uma Grécia adstringida onde a prática e os valores do infanticídio são aceitos não por uma questão moral ou de perversidade ingênita, mas pelo imperativo das dificuldades, em função do ônus insuportável de reproduzir uma individualidade que não será capaz de se autogerir e nem de contribuir com a comunidade.

Outro aspecto importante ressaltado por Cambiano diz respeito à centralidade da figura masculina na formação moral e militar do jovem grego. Na Grécia, a figura masculina se projeta, sob formas distintas, em todos os interstícios da sociabilidade. Dos tempos homéricos, do oikos aristocrático, dos heróis tão vivamente narrados pela mitologia, é reconhecido o esplendor corporal, tipificado na força, na destreza, na aptidão e na coragem. Da Grécia clássica, temos o homem político, proprietário da terra, soldado e estadista, homem prudente, de subjetividade ativa que, na condição de cidadão, ordena e possibilita a convivência comunal. $\mathrm{O}$ fato é que, mesmo nas distinções, a figura masculina é centro dos anseios e das perspectivas comunais. Ela, em sua lógica, canaliza o que de mais valoroso se pode esperar, almejar e vivenciar. O artesanato e, principalmente, as artes sinalizam isso muito bem: dos vasos às esculturas o que se assiste é à exaltação da beleza, à divinização do corpo, sua dimensão atlética e fisicamente perfeita, própria dos deuses ou de um homem que, aos poucos, busca humanizar os deuses.

Cambiano mostra, com pertinência, alguns momentos desta paidéia. Inicialmente, o autor esclarece que, desde cedo, por volta dos doze anos, o adolescente é levado à prática de atividades físicas, em ginásios apropriados. Trata-se, em primeiro lugar, de aprendizado para o exercício da vida comunitária e, simultaneamente, aprendizado para a futura vida militar. A prática de exercícios em equipe, a necessária cooperação entre os seus participantes contribuía e muito para a formação moral dos indivíduos. Por outro lado, nos ginásios eram ensinados alguns exercícios militares que, na mesma direção, alimentavam o sentimento de comunidade entre os participantes. Assim, Cambiano mostra que a verdadeira formação moral do indivíduo se dá para além de sua casa, na convivência com os futuros cidadãos, na companhia de outros homens 
que serão, em futuro próximo, estrategos e/ou políticos. De sorte que a homossexualidade grega é enformada em tais circunstâncias, e o sexo feminino é relegado às tarefas secundárias ou meramente reprodutivas. Percebe-se que para Cambiano, o homossexualismo grego contém uma "dimensão pedagógica" que, necessariamente, contribuiu "para a formação moral e intelectual" do jovem grego.

Uma vez mais, então, e isto é o que se deseja fundamentalmente marcar a partir dos argumentos e reflexões de Cambiano, aparece a dimensão comprimida da formação social grega, na qual a exaltação da figura masculina bem como as tendências de talhe homossexual devem ser apreendidas não como uma dimensão de caráter meramente estético, de um lado, ou como simples opção pelo homossexualismo, de outro; mas, acima de tudo, como forma de exaltar a única figura que pode se responsabilizar pela reprodução material da comunidade, pelo ordenamento da mesma e pela defesa de seus cidadãos, em cenário adverso. Eis que a figura masculina emerge como força produtiva, força política, força militar e força moral em contexto de diminutas energias sociais.

Por fim, com o que se conclui este caminho introdutório, parece oportuno tecer algumas considerações sobre a estrutura deste trabalho, as partes constituintes e sua relação com os capítulos.

Em primeiro lugar, nosso propósito é trabalhar dois eixos fundamentais e conexos. O primeiro eixo (Parte I) diz respeito à forma social grega, sua organização e modo de vida. Ao rastrear a vida comunitária grega, esta nos revela o seu segredo: o fato de ter no limite a dimensão, a lógica de ser e de existir da comunidade. Em outras palavras, o apelo ao limite é antes de mais nada determinação existencial, lógica profana, modus vivendi. Para compreender tal dimensão, será necessário um amplo estudo histórico, revelando aspectos fundamentais da Grécia arcaica e clássica, de seu apogeu e declínio, dos principais aspectos econômicos e políticos. Aqui se insere o caráter da pesquisa histórica, como ciência da história, isto é, como investigação do tecido social, dos problemas da pólis e de suas urgências.

O segundo eixo (Parte II), a ser examinado, diz respeito à manifestação ideal do limite, sua expressão reflexiva, notadamente na política e ética aristotélicas. Tal exame decorre, necessariamente, das aquisições históricas e da compreensão do modo de vida grego, pois só no interior da história grega é que podemos entender os movimentos da subjetividade, notadamente a aristotélica que buscou, como ninguém, compreender o seu tempo. Trata-se de reconhecer o ideário político aristotélico, sua exortação ao limite, como manifestação da urdidura social, de reconhecer uma comunidade que, 
paulatinamente, perde as condições do exercício do limite, tanto no âmbito público, como no âmbito privado. Indivíduo e comunidade encontram, na política e na ética, os limites próprios de sua atuação, de suas finalidades, como se intentará mostrar no curso dos argumentos.

Por último, cabe traçar a estrutura capitular das Partes I e II. Inicialmente, a tese abre com um capítulo voltado à história ateniense, notadamente a partir do fato econômico mais relevante: a emergência da propriedade privada móvel ateniense. Tratase de um momento singular da vida grega, em especial de Atenas, que compreende o nascimento e amadurecimento das instituições da pólis, com Sólon, passando pela tirania de Pisístrato, pelas reformas de Clístenes, pelo apogeu de Péricles e, no plano militar, por guerras que, a partir do século IV, se tornam endêmicas. Dentro deste contexto, entre a idade de ouro da política e seus impasses, avulta o pensamento do filósofo de Estagira. Motivo pelo qual a vida e a obra de Aristóteles têm a marca das melhores esperanças gregas e, simultaneamente, de suas inviabilidades, de suas derrotas e de um passado morto. De modo que o capítulo permite reconhecer a conexão entre a história grega e a formação ideal aristotélica, dando, de pronto, as condições para a investigação dos propósitos do ideário político de Aristóteles, bem como dos constrangimentos, limites e impossibilidades da formação social grega.

O segundo capítulo apresenta um estudo voltado à teleologia aristotélica, suas manifestações, sua essência enquanto força social limitada notadamente na relação entre senhor e escravo. Este capítulo se volta ao exame da relação limitada do homem grego com a natureza; o baixo desenvolvimento das forças produtivas e a pouca transformação advinda de tais circunstâncias. Trata-se de capítulo importante, pois desenha o perfil comunitário grego, dos limites e impossibilidades como forma de ser, lógica da vida in communitas. Com este capítulo se fecha a análise da organização social grega, sua ordem nas condições de adstringência. Dessa maneira, as aquisições desta primeira parte permitem compreender e desnudar, dentro do possível, as perspectivas aristotélicas, a importância da política e, complementarmente, da ética.

Na Parte II, a reflexão recai sobre as formações ideais, notadamente nas figuras da política e da ética. O propósito é examinar a natureza da política, sua relação com a formação social grega, seus vínculos e a que necessidades corresponde. Trata-se de dar contorno à unidade entre objetividade e subjetividade já aludida, esclarecer a natureza da política e da ética num contexto em que a sociabilidade clama pelo limite; em que política e ética configuram o limite possível, desejável, no singular e no plural, para a 
vida grega. Assim, os capítulos ganham a seguinte fisionomia: o primeiro retoma algumas considerações históricas, notadamente a crise agrária do século VI, para focar a importância histórica de Sólon em $C A$. Dada a gravidade do problema da terra, temos a célebre intervenção soloniana, extinguindo a escravidão por dívidas, agindo com moderação e criando um código de leis. Sólon configura o tipo de político a ser seguido, a mediania personificada. Tais são os traços caracterizados por Aristóteles em CA. Em seguida, Aristóteles estabelece a possibilidade de que um tirano fosse moderado. É o caso de Pisístrato que exerce a tirania sem exageros, beneficiando os pequenos camponeses. Por fim, faremos a conexão entre a caracterização de Sólon e o governo da classe média, da politéia. Aristóteles caracteriza a politéia como a forma mais equilibrada do poder amplo dos cidadãos, pois a classe média se põe na mediania, isto é, nem excessivamente pobre, nem rica, mas equilibrada para objetivar o bem comum. Nesse sentido, temos uma articulação e desdobramento de idéias entre CA e Política.

Após a caracterização da melhor forma constitucional e das virtudes necessárias ao exercício do poder político, faz-se necessário, em outro capítulo, compreender o mecanismo pelo qual a comunidade política é regulada. Aqui, comparece o instrumento da justiça, que se põe como intermediário da vida comunitária, de seus problemas e objetivos. Dito de outro modo, a justiça é a forma profana da política, encarregada de dirimir conflitos, tensões na perspectiva de que o justo-meio prevaleça, evitando-se a perda ou o ganho em excesso. É o capítulo V de EN que traduz os objetivos da política, sua vivência nos mais variados ramos da justiça cuja finalidade e sentido são a moderação e a preservação da comunidade política.

Ainda no interior da justiça, cabe examinar, na forma de subcapítulo, o expediente do ostracismo. No Livro III da Política [1284 a e b] ${ }^{49}$, Aristóteles analisa outro expediente político que merece nossa atenção, ou seja, o da instauração do ostracismo na Grécia. A grosso modo, o estagirita nos põe diante dos seguintes fatos: nascido nos governos democráticos, o ostracismo foi, acima de tudo, uma fórmula jurídica destinada a manter a medida nas democracias, a igualdade de seus cidadãos. Aquele que, por seus méritos, riquezas ou popularidade atentasse à medida, sobrepujando-se a ela, era expulso de sua cidade por tempo determinado, ou melhor, ninguém poderia ultrapassar, em qualquer esfera, o aceitável para a comunidade. O que encontramos, uma vez mais, é a esfera jurídica mantendo as possibilidades da vida comunitária, ordenando que a

49. Cf. a tradução da Política, já citada e organizada por J. Aubonnet. 
medida fosse preservada mesmo que não restasse aos melhores cidadãos senão o exílio.

Por último, e em conexão com as considerações sobre a justiça, resta ainda, em capítulo próprio, analisar a $E N$ e suas implicações. Na $E N$ é nítido o sentido moderador que a perpassa. Aristóteles estende o conceito de mediania a uma pluralidade de fatos da vida cotidiana. O que vale discutir é a raiz da mediania, examinar se a prudência grega se origina da simples constatação de que se deve ser moderado num mundo contingente ou, ao inverso, reconhecer a moderação ética como resultado das necessidades de uma comunidade que deve ser contida dentro de limites que permitam sua existência.

Em suma, só o efetivo desenrolar da pesquisa histórico-filosófica mostrará a pertinência dos temas. De qualquer modo, o direcionamento colunar está dado, cabe a nós trilhar suas possibilidades. 
$1^{\text {a }}$ PARTE: O LIMITE COMO FORMA DE SER DA COMUNIDADE 


\section{A P Í T U L O I}

\section{A EMERGÊNCIA DA PROPRIEDADE PRIVADA MÓVEL ATENIENSE: O ESCRAVO-MERCADORIA.}

Este capítulo pretende expor, na modicidade de limites factíveis, a ordenação e dinâmica da formação social grega; em especial, a trajetória de desenvolvimento da propriedade privada móvel ateniense; a emergência da figura do escravo e de seu papel na economia antiga. Trata-se, portanto, de considerar o papel do trabalho cativo como força produtiva comunal, sem desconsiderar a própria comunidade como força produtiva, enlace decisivo e essencial da formação e constituição da pólis grega. Exame difícil, pois as categorias econômicas aparecem como pertencentes ao oikos, vale dizer: a economia se organizava a partir de necessidades estritamente familiares, o que implica, por sua vez, produção local, limitada e de pouca mercância. Mesmo quando, a partir de determinado momento, o comércio propriamente dito vem a se instalar, a produção nunca esteve voltada para a troca. Assim, e por este motivo, as categorias econômicas não aparecem como categorias gerais, de cunho e de interesse públicos, descoladas e providas de esfera e limites próprios, como milênios depois vieram a adquirir em plena modernidade, moldando a anatomia da sociedade civil; mas, ao inverso, como interesse puramente doméstico e familiar, o que, em si, dificulta os estudos econômicos. Por isso, os gregos não conheciam sequer o conceito de economia ${ }^{1}$, pois sua esfera se mesclava de forma indistinta com outros campos, desde a ética, a política e a vida comunitária, revelando, de pronto, a não autonomia de suas categorias, seja no plano sensível objetivo ou no plano de sua reprodução ideal. Ora, o trabalho escravo - como força produtiva - parece apontar uma definição clara do modo a partir do qual os meios de vida eram produzidos, quer dizer: é a forma de trabalho que, a despeito das diferenças, está historicamente envolvida com o desenvolvimento e ápice da cidade-estado grega; de modo que, o trabalho escravo aparece - aos historiadores - como categoria capital da economia antiga ou, pelo menos, como ponto relevante a despontar os destinos da pólis. Daí, os

1. Cf., FINLEY, M. A Economia antiga, p. 5. 
interesses de Finley, Vernant, Vidal-Naquet, Austin, Anderson, Mossé e outros pela compreensão e elucidação das formas e desenvolvimento do trabalho cativo.

Em seguida, serão analisadas - o que subentende uma articulação com os motivos expostos acima - algumas dimensões capitais da emergência progressiva da comunidade política ateniense, sua singularidade e declínio próprio. Em termos históricos, significa ressaltar as condições objetivas que permitiram a ascensão da comunidade política, ou seja, pôr em relevo os traços mais significativos que, no âmbito econômico, propiciaram o trânsito da autarquia do oikos aristocrático à polis clássica ateniense. Com o que se afigura a possibilidade de estabelecer mediações entre o plano real - das categorias $^{2}$ econômicas, mesmo incipientes e pouca nítidas, e o plano ideal, das proposituras aristotélicas; em suma: em que medida - para retomar o espírito de nossa Introdução - os dilemas, as dificuldades e os limites da comunidade política ateniense influenciaram decisivamente o ideário político-ético do filósofo de Estagira? Certamente muito. O que permite mostrar e reconhecer a política e a ética aristotélicas como tributárias, de modo mediado, do declínio e da perda de medida da pólis ateniense. Vale ressaltar, entanto, que a caracterização do trabalho escravo não é o tema central de nosso estudo; mas, justifica-se, por permitir - a partir de contrastes históricos - identificar aproximadamente as influências e estímulos decisivos que nortearam os caminhos da reflexão do autor em tela. Com o que, assim se avaliam as mediações de fundo e função da esfera política na Grécia aristotélica.

Esboço que se inicia, para retomar os argumentos da Introdução, no interior das Formen. Cabe assinalar, no entanto, as dificuldades, os desafios, e o caráter polêmico do texto como observa Hobsbawm ${ }^{3}$ em sua introdução. Nesta, Hobsbawm sintetiza a especificidade do discurso marxiano: o fato de ser um manuscrito que, ao examinar as formações econômicas pré-capitalistas, promove, como a letra e o espírito marxiano, a fusão entre história, economia e filosofia. Vejamos, portanto, como o desenvolvimento das formas de propriedade, em especial da propriedade privada móvel, acaba por constituir as possibilidades e a própria emergência da pólis clássica ateniense.

2. Ao se afirmar que as categorias não são apenas formas ideais, mas formas de existência, busca-se inspiração em Marx, quando da crítica à economia política clássica contida na afamada Introdução de 57 (Grundrisse). Nesta, o filósofo é claro: “as categorias exprimem, portanto, formas de modos de ser, determinações de existência”. In: Manuscritos Econômico-Filosóficos e outros Textos Escolhidos. Coleção “Os Pensadores”. Abril Cultural, vol..XXXV, p.127.

3. Cf., HOBSBAWM, E. Introdução in Formen, p.13-6. 
Marx assinala, com riqueza de argumentos, as distinções entre os modos de ser da propriedade comunal. Em primeiro lugar, examina os contornos da comunidade oriental; num segundo momento, é examinada a comunidade clássica greco-romana, a que de fato nos interessa; por fim, investiga a comuna germânica, própria à formação feudal. Nosso interesse pela letra marxiana recai, portanto, em seu exame sobre a comunidade greco-romana, sobre sua especificidade e modo de vida, porquanto é no interior desta que se desenvolve a propriedade privada móvel, a cidade grega e, notadamente, marquese desde já, a comunidade política instaurada a partir dos séculos VII-VI a.C. Contudo, e com fins a uma necessária visão processual que permite a delimitação e a compreensibilidade da parte específica, tomamos a reflexão marxiana a partir de seu ponto de partida, ressaltando, no entanto, mesmo de modo breve, que o filósofo alemão em seus Grundrisse não almejasse estabelecer, nem mesmo longinquamente, uma linha evolutiva de tais formações societárias. Muito ao contrário, o que a letra marxiana revela é a intenção de demarcar as diferenças específicas entre essas formações societárias e a formação social burguesa cujas relações sociais entre os indivíduos são mediadas pelo valor.

\section{Da comunidade Oriental.}

Na chamada comunidade oriental, avulta como essência, como seu atributo peculiar fundante, o fato de inexistir a figura da propriedade individual da terra, mesmo aquela mediada pela comunidade. Indivíduo e comunidade, em tal contextura, estão diretamente ligados por interesses imediatamente recíprocos - pela satisfação de necessidades primárias, da sobrevivência imediata-, o que significa a existência de uma produção e apropriação a partir de uma ordenação humana primordial: a auto-subsistência. Em tais circunstâncias, o indivíduo se relaciona com outro indivíduo na condição de um intercâmbio mútuo do qual depende a sobrevivência recíproca. Trata-se de uma formação social na qual a totalidade é força produtiva, na qual é impensável e mesmo inexistente qualquer cissura que contraponha ou ameace a unidade de seus membros. Vale dizer, inexiste qualquer cisão ou diferenciação que se interponha entre o indivíduo e sua comunidade, mesmo porque tal clivagem implicaria ruína social. Ora, o que aparece neste momento da vida é a determinação marxiana da comunidade como amálgama unitário, enquanto força social comunal, como revelam as palavras do filósofo: 
O primeiro pressuposto desta forma inicial de propriedade da terra é uma comunidade humana, tal como surge a partir da evolução espontânea (naturwüchsig): a família, a tribo formada pela ampliação da família ou pelos casamentos entre famílias e combinações de tribo. Pode-se considerar como certo que o pastoreio ou, dito de forma mais geral, a vida nômade é a primeira forma de sobrevivência, na qual a tribo não se estabelece em lugar fixo, aproveitando, antes, o que encontra no local e logo indo adiante /.../ Portanto, a comunidade tribal, o grupo natural, não surge como conseqüência, mas como a condição prévia da apropriação e uso conjunto, temporários, do solo. $^{4}$

Trata-se da caracterização marxiana do indivíduo como membro indistinto de um todo indistinto, de um rebanho, de uma sociabilidade ainda não efetivamente afigurada e internamente diferenciada pelo surgimento da propriedade privada e da divisão social do trabalho. Uma comunidade dependente não só do que a natureza lhe oferece, mas, e isto importa marcar de pronto, do outro homem: este como instrumento imediato do trabalho comunal. E nesta configuração comparece a propriedade comunal em sua forma inicial, em que a propriedade é móvel (animais) e o uso da terra como pertença da comunidade. Na reflexão de Marx:

Na verdade a propriedade é, originalmente móvel, porque em primeiro lugar o homem toma posse dos frutos disponíveis da terra, inclusive animais e, especialmente, os passíveis de domesticação. Entretanto, mesmo esta situação - pesca, caça, pastoreio, subsistência pela coleta dos frutos das árvores, etc. - sempre pressupõe a apropriação da terra, seja como um local de fixação ou um território para deslocamento, uma pastagem para os animais. ${ }^{5}$

Pela argumentação exposta cabe ressaltar, pois, numa primeira aproximação, que o modo pelo qual o homem ou o grupo a que pertence se ata e apropria da natureza engendra formas relacionais que implicam o aparecimento de formas de propriedade, modos produtivos, logo, e mediatamente, de formações sociais. Em outros termos, o grupo comparece como força produtiva e, portanto, a apropriação do solo como propriedade comunal. Assim, na antiguidade, ao indivíduo, como pertença do grupo, permitir ou não o acesso à terra e aos meios de produção explica-se, naquele momento histórico preciso, pelos limites próprios de desenvolvimento das forças produtivas, do nível e âmbito de capacitação humana então existente, do tipo de intercâmbio orgânico com a natureza, determinando o modo pelo qual se dá o acesso à propriedade. Vale dizer, o acesso à

4. K. MARX, Formen, p. 66.

5. Ibid., p. 86. 
propriedade, mediado pela comunidade, deriva desse modo mais amplo e fundante da relação homem/natureza, sempre enformado pelo nível de desenvolvimento das forças produtivas. No momento inicial deste processo, a propriedade, então, nasce como satisfação limitada das precárias necessidades humanas, de uma apropriação e uso puramente animal da natureza, ou seja, o homem é meramente coletor dos frutos que esta lhe proporciona. De fato, inicialmente a apropriação comunal dos bens do solo é o modo possível de reproduzir o indivíduo e o gênero existentes em condições de extremo limite. Aqui, o homem é predominantemente natureza e a apropriação segue uma lógica quase natural, de tão precária e dependente que está a comunidade em relação ao quadro natural. Daí o indivíduo ser posto, qualitativamente, como membro da manada, do rebanho. De modo que, e este ponto é vital,

..../originalmente, propriedade significa nada mais do que a atitude do homem ao encarar suas condições naturais de produção como lhe pertencendo, como pré-requisitos de sua própria existência; sua atitude em relação a elas como pré-requisitos naturais de si mesmo, que constituiriam, assim, prolongamentos de seu próprio corpo. ${ }^{6}$

Percebe-se, então, que na origem e formação da propriedade a adstringência é dimensão humano-social fundante: a propriedade em seus pródromos, vale repetir, é a apropriação dos recursos necessários à reprodução estrita dos indivíduos e da ordem comunal. Neste contexto, a propriedade é extensão do próprio corpo, pois a terra é com efeito

/.../o grande laboratório, o arsenal que proporciona tanto os meios e objetos do trabalho como a localização, a base da comunidade. As relações do homem com a terra são ingênuas: eles se consideram como seus proprietários comunais, ou seja, membros de uma comunidade que se produz e reproduz pelo trabalho vivo ${ }^{7}$.

Efetivamente, ocorre a cessão da terra aos indivíduos, logo, sua posse; existe, ainda, a interdição de sua apropriação privada por um proprietário que assim se constitui. Em tais condições de vida, ressalta Marx, ou nas condições da absoluta unidade entre indivíduo e comunidade, "o indivíduo /.../ nunca se torna um proprietário, mas somente um possuidor, ele mesmo é, no fundo, a propriedade, o escravo daquilo que corporifica 
a unidade da comunidade" ${ }^{8}$. Nesse sentido, o indivíduo é imediatamente comunidade e a comunidade imediatamente indivíduo. De sorte que é impossível encontrar, reitere-se, qualquer fissura que demonstre o aparecimento da individuação - do indivíduo que começa a se diferenciar da comunidade. Isto, por sua vez, denota fraqueza estrutural, impossibilidade de reproduzir a comunidade em níveis mais desenvolvidos, mais amplos, pois o verdadeiro empuxo da comunidade grega seria o surgimento da propriedade privada e, por extensão, de novas formas de trabalho que permitiriam novas conquistas, novas aquisições e novos desafios, mas também outras formas de limites.

\section{Da comunidade greco-romana - o oikos.}

A segunda forma comunal de propriedade, a greco-romana, arrima-se no desenvolvimento da propriedade privada da terra, justapondo-se à terra pública, do Estado. Diversamente e em contraste nítido com a comunidade oriental, emerge a figura da apropriação privada do solo, mesmo que - muito embora - mediada pela comunidade e esta mediação é, sem dúvida, um de seus traços marcantes. Desta feita, a apropriação privada do solo no interior da propriedade comunal, do Estado, impõe distinções estruturais face ao modus operandi da propriedade comunal, pois a figura do proprietário privado funda um novo modo de ser da comunidade: o da cisão entre proprietários e não proprietários da terra. A terra passa da condição de propriedade comunal dos indivíduos (comuna oriental), para a apropriação privada do solo, mas sob a importante mediação da comunidade, o que coexiste com o uso público das terras do Estado. Em verdade, temos simultaneamente dois movimentos: o primeiro diz respeito ao aparecimento da figura do cidadão e da propriedade privada do solo; o segundo, em confluência com o primeiro, significa a emersão da propriedade privada móvel, o escravo. Em outros termos, o solo se torna privado e a propriedade comunal móvel, caracterizada pelos recursos naturais da terra e de seu uso na comuna oriental, se converte em propriedade privada do cidadão na figura de escravo. Assim Marx, corroborando as diferenças delineadas entre as duas formas comunais, afirma:

8. Ibid., p.87. 
A comunidade é, aqui, também, a condição prévia, mas, diferentemente de nosso primeiro caso, não mais constitui a substância da qual os indivíduos são simples acidentes (Akzidenzen) ou meros componentes naturais espontâneos. A base, aqui, não é a terra, mas a cidade, núcleo já estabelecido (centro) da população rural (proprietários de terras). A área cultivada é território da cidade, enquanto no outro caso, a aldeia era simples apêndice da terra. ${ }^{9}$

Explicitando o problema: em primeiro lugar e diferentemente da comunidade oriental, emerge a figura do proprietário da terra, do citadino, que reordena o modo de vida anterior; a terra é vinculada à cidade e a esta se subordina. Em tal contexto, é próprio firmar que o cidadão se esboça enquanto força social efetiva, real e ativa na confluência com o escravo-mercadoria que sustenta e viabiliza tal processo. Sobre isso, Austin e Vidal-Naquet afirmam:

\footnotetext{
Atenas será, na época clássica, a cidade onde o cidadão verá o seu poder e os seus direitos desenvolverem-se mais do que em qualquer outro lugar; mas será ao mesmo tempo a cidade onde a escravatura-mercadoria conheceu a sua maior expansão. Não se trata de uma simples coincidência: é mesmo o caso mais nítido em que se pode estabelecer uma ligação entre os dois processos, por um lado, o desenvolvimento da noção de cidadão livre e a eliminação dos súditos internos, por outro lado, o desenvolvimento de uma nova forma de servidão, a da escravatura-mercadoria importada do estrangeiro. ${ }^{10}$
}

Tentemos, pois, caracterizar a importância da propriedade privada móvel e imóvel, seu processo e implicações. Iniciemos o exame pelo estatuto do oikos aristocrático, que já comporta a presença da propriedade privada. Aqui, Homero é figura central, pois o desenho e o perfil da estrutura familiar do oikos é, sobretudo, exposta em seus poemas. É sob este prisma que o autor nos chama.

Finley, em Economia e Sociedade na Grécia Antiga ${ }^{11}$ se refere ao período homérico como a época na qual a propriedade privada estava já definida, clara, pois a herança - enquanto direito adquirido - é, nos clãs, fato cotidiano, dimensão importante que garante a perpetuação e o repasse - de uso e fruto - da propriedade (móvel e imóvel) aos familiares. O mesmo, no entanto, não ocorre face às relações familiares; ora, Finley destaca como as relações entre senhor e escravo ainda são relações de pessoalidade, como descreve no Mundo de Ulisses:

9. K. MARX, Formen, p. 69.

10. M. AUSTIN, \& P. VIDAL-NAQUET, Economia e sociedade na Grécia antiga , p.81.

11. M. FINLEY, Economia e sociedade na Grécia antiga, p. 235-6. 


\begin{abstract}
Uma profunda clivagem horizontal estratificava o mundo dos poemas homéricos. Em cima, os aristoi, possuíam a maior parte das riquezas e todo o poder, em tempo de paz como em tempo de guerra. Em baixo, conservavam-se todos os outros, a multidão que nenhum termo técnico definia coletivamente. $\mathrm{O}$ fosso que separava estes dois estatutos raramente era transposto, salvo por efeito de acidentes devido às guerras e às rapinas /.../ Mesmo um contraste tão simples como o que opõe o escravo e o homem livre não aparece desenhado com uma inteira clareza. O termo drèster, por exemplo, que significa 'uma pessoa que trabalha para ou que está ao serviço de' é utilizado na Odisséia tanto para os homens livres como para os escravos. O trabalho de uns e de outros, a maneira como eram respectivamente considerados tanto pelos seus senhores como no espírito do poeta, é amiúde impossível de distinguir. ${ }^{12}$
\end{abstract}

Finley nos adverte para o fato de que nem sempre é possível reconhecer - no modo de vida do oikos - as dessemelhanças fundamentais que opõem homem livre e escravo. Vale dizer, os contrastes que virão sedimentar a contraposição entre homem livre e escravo, séculos mais tarde, aparecem aqui em forma germinal, não desenvolvida, ou incompletas em seu processo, portanto, pouco claras em sua dinâmica própria. No mesmo universo de ponderações acerca da natureza do oikos e de sua forma de trabalho escravo, Mossé, em A Grécia Arcaica de Homero a Ésquilo, dispõe da mesma tese ao considerar tal forma de escravatura patriarcal ou, ao menos, próxima deste fenômeno cujas implicações importam na ausência ou "imprecisão de um estatuto que não erguera ainda entre senhores e servos a barreira que, na época clássica, virá a separar o escravo do homem livre". ${ }^{13}$

Assim, Mossé assinala a impossibilidade de uma fissura efetiva entre o chefe do oikos e o escravo; impossibilidade indicante, mediatamente, de que ainda não estavam dadas as condições do contraste entre as partes. Em outras palavras, o oikos aristocrático, em sua rusticidade e fragilidade, comportava apenas relações humanas em linear unidade. Mossé aponta, enfim, a inexistência de limites claros ou rígidos que separavam os estamentos sociais, do que surge a fluidez que marcava as relações estamentais entre os membros do oikos. O que encontramos no oikos, pois, são relações típicas da unidade familiar. A força do oikos era resultado da coesão de seus membros, que permitia, em limites estreitos, sua auto-reprodução. Uma vez mais, palavras de Austin e Vidal-Naquet que expressam tal estatuto e lógica:

12. IDEM, O mundo de Ulisses, p.73-4.

13. c. MOSSÉ, A Grécia arcaica de Homero a Ésquilo, p. 67. 
/.../o critério essencial para estabelecer o estatuto de um homem no mundo homérico não era a posse ou não da liberdade pessoal, mas a distância em relação ao oikos. O estatuto de um homem não se define em abstrato, mas em relação com a sua integração ou não num grupo e, no mundo homérico, a unidade é o oikos aristocrático, não a pólis. Por conseguinte, o termo inferior é, não a situação do escravo, mas sim a do teta, homem livre, mas que nada possui, e que se vê, pois, obrigado, para viver, a vender os seus serviços a outrem, colocando-se assim na sua dependência sem sequer poder ter a certeza de receber o salário estipulado. /.../ No interior de um oikos, o nível de um escravo pode variar: entre os escravos, homens e mulheres, que fazem parte do oikos de Ulisses, pode-se distinguir dois grupos. A par dos escravos vulgares, que não fazem mais do que executar as ordens que lhe são dadas, existe um grupo de privilegiados que gozam da confiança e da estima dos seus senhores e participam da gestão do oikos. ${ }^{14}$

Ora, o que se observa é que Austin e Vidal-Naquet reafirmam a dimensão de menor antagonismo entre senhor e escravo se comparado aos tempos clássicos atenienses. Nesse sentido, encontramos uma posição até mesmo privilegiada do escravo face aos tetas que não pertenciam ao oikos e que não gozavam da proteção e da segurança de pertencerem ao clã. Os tetas, e isto é bastante esclarecedor, mesmo na condição de homens livres, estavam em situação de maior contraste na relação com o chefe do oikos, pois esta não era mediada pela confiança, pela co-participação nos problemas do oikos e, notadamente, pela unidade, que fazia do oikos, até certo ponto, uma autarquia. Ademais, Finley afirma a possibilidade de que um grupo de escravos, em situação especial, participasse da gestão do oikos, algo que para a pólis clássica ateniense seria pura irrealidade. Logo, Austin e Vidal-Naquet reforçam a tese de Finley, em trecho citado, de que a hierarquia do oikos tem um caráter claramente horizontal e que as diferenças estamentais não instituem um fosso entre as diferentes esferas, como ocorrerá na Atenas do século V.

Delimitado tal quadro, é preciso sublinhar que para o oikos inexiste a propriedade privada tal qual será firmada no século $\mathrm{V}$ a.C, por conseguinte, pouco se pode notar da força de trabalho típica da Atenas clássica - o escravo-mercadoria. Assim, a Atenas clássica, no que tange à organização laboral, privatiza o indivíduo, que se faz propriedade privada móvel, vendida e manipulada a partir das necessidades e conveniências de seu amo. Em contraste nítido com esta orgânica, nos tempos das narrativas homéricas, a inserção do cativo na vida do oikos garantia, quase sempre, a compaixão, a estima e a

14. M. AUSTIN \& P. VIDAL-NAQUET, Economia e sociedade na Grécia antiga, p. 54-5. 
proteção de seu senhor. Por outro lado, o comércio quase inexistente dificultava, para o senhor do oikos, a aquisição de mão-de-obra, deixando-lhe como única alternativa a pilhagem pela guerra. Alternativa que, em tempos mais duros ou difíceis, era sempre um risco que, por prudência, deveria ser, nas mais das vezes, descartado.

Em Economia e Sociedade na Grécia Antiga, no que se refere às formas de trabalho escravo, desenha-se uma contextura que importa aqui pontuar, porquanto esta amplia a consciência sobre as diferenças que separam os espaços arcaico e clássico gregos. Pondera Finley:

\begin{abstract}
Se pensarmos na sociedade antiga, como um espectro de classes sociais, com o cidadão livre em um extremo e o escravo no outro, e com um considerável número de graus de dependência no meio, descobriremos rapidamente 'linhas' diferentes no espectro: o hilota espartano (com similares como o penestres da Tessália); o escravo por dívida, que não era um escravo, embora em certas condições pudesse eventualmente ser vendido como tal no exterior; o escravo alforriado condicionalmente; e, finalmente, o homem livre. Essas categorias raramente, ou nunca, apareciam simultaneamente na mesma comunidade, nem tinham a mesma importância ou a mesma significação em todos os períodos da história grega. De modo geral, o escravo propriamente dito era a figura decisiva (com a virtual exclusão das outras) nas comunidades econômica e politicamente avançadas; já a 'hilotagem' e a escravidão decorrente de dívidas eram encontradas nas comunidades mais arcaicas, como Creta, Esparta ou Tessália, na mesma data tardia, ou então em Atenas do período anterior a Sólon. Há também alguma correlação, embora não perfeita, entre as várias categorias de trabalho dependente e sua função. A escravidão foi a mais flexível das formas, adaptável a todos os tipos e níveis de atividade, enquanto a 'hilotagem' e as demais se adaptavam melhor à agricultura, ao pastoreio e aos serviços domésticos que à manufatura e ao comércio. ${ }^{15}$
\end{abstract}

O texto, pois, remete a determinações relevantes acerca da natureza do trabalho escravo, num gradiente de possibilidades que se deslocam da escravidão por dívidas, passa pelo hilota espartano e alcança a forma do escravo-mercadoria dos tempos clássicos. Finley trabalha categorias efetivas, estamentos que existiram, particularidades na forma de ser do trabalho escravo, desviando-se de uma abordagem de talhe filológico ou meramente conceitual, abstrata, que interdita a apreensão do tecido histórico em si. Neste movimento, Finley aborda a categoria da escravidão por dívidas na direção de reconhecer que este escravo é, ainda, uma forma híbrida do trabalho cativo, pois o mesmo não podia ser vendido, a não ser excepcionalmente, ao mesmo tempo em que, indubitavelmente, encontrava-se na condição de escravo. Do mesmo modo, e a partir da mesma perspectiva teórica, Finley mostra como nos tempos homéricos o escravo fazia 
parte do oikos como pertença não privada, vale a expressão, da família. Assim, Finley reconhece que o cativo por dívidas era, na Grécia arcaica, forma comum e mesmo conveniente de conseguir mão de obra para a terra. De fato, para a aristocracia fundiária, a escravidão por dívidas representou um modo simples e menos perigoso de conseguir cativos, pois assim se evitavam guerras e o pior: suas decorrências. O cativo por dívidas se encontrava na condição e nas obrigações do escravo, sem ser propriamente escravo: a escravidão por dívidas situava o indivíduo na forma do trabalhador cativo, podendo, por sua vez, superar esta condição; o exemplo de Sólon é mister. Ao inverso, e no que diz respeito ao escravo propriamente dito - conquistado por guerras ou comprado nas praças -, a possibilidade de ascender a uma condição não servil, a não ser pela benevolência de seu senhor, é eliminada como perspectiva, pois jamais lhe foi dado o direito de conquistar sua liberdade, a não ser pelas graças do seu senhor ou, em casos excepcionais e dependendo da cidade, pelo Estado. Esta diferenciação mostra os interstícios do processo formativo do trabalho escravo grego, revelando, por sua vez, que a produção baseada no escravo comporta distinções importantes na condição da escravidão, visto que comporta processos de mutação internos. Finley evidencia melhor a natureza do escravo por dívidas:

\footnotetext{
Os homens que Sólon libertou pertenciam a uma classe restrita embora numerosa: eram atenienses que tinham caído na escravidão de outros atenienses em Atenas. Seu programa não se estendia aos não atenienses, forasteiros, que eram escravos em Atenas /.../ Os escravos atenienses tinham continuado atenienses; agora reafirmavam seus direitos como atenienses e forçavam o fim da instituição - servidão por dívida - que os tinha privado de fato de todos ou da maioria desses direitos. Não se opunham à escravidão como tal, somente à sujeição de atenienses por outros atenienses. Portanto, qualquer que seja a semelhança superficial, essa não foi uma revolta de es$\operatorname{cravos}^{16}$.
}

Ao abolir a escravidão por dívidas, Sólon restituiu os direitos políticos ao pequeno camponês ateniense, tirando-lhe da condição de escravo. Ao restituir os direitos políticos ao indivíduo de condição cativa, Sólon acaba com o estado de escravidão do ateniense que, outrora e por razões econômicas, foi forçado a assumir a condição de escravo em sua forma acabada, pois privado inteiramente de liberdade pela sujeição à venda.

16. M. FINLEY, Economia e sociedade na Grécia antiga, p.125. 
A mesma questão é discutida por Perry Anderson, que em passagem polêmica, refere:

As cidades-Estado gregas tornaram a escravatura pela primeira vez absoluta na forma e dominante na extensão, transformando-a desse modo de recurso de subsidiário em modo de produção sistemático. O mundo helênico clássico, é claro, nunca assentou exclusivamente no uso do trabalho escravo. Camponeses livres, rendeiros dependentes, artesãos urbanos sempre coexistiram com os escravos, em combinações variáveis, nas diferentes cidades-Estado da Grécia. Além disso, o seu próprio desenvolvimento externo e interno podia alterar marcadamente as proporções entre ambos de um século para o seguinte /.../ Mas o modo de produção dominante na Grécia clássica, que regia a complexa articulação de cada economia local e dava o seu cunho a toda a civilização da cidade-estado, era o escravista /.../ O conjunto do Mundo Antigo nunca foi na sua continuidade e extensão marcado pela predominância do trabalho escravo. Mas as suas grandes épocas clássicas, em que floresceu a civilização da Antiguidade (a Grécia dos séculos V e IV a.C. e a Roma do século II a.C. ao século II d.C.), foram aquelas em que a escravatura foi massiva e geral, entre outros sistemas de trabalho. ${ }^{17}$

Assim, deve ser referido que Anderson sustenta a idéia de que o pleno escravismo só ocorreu nos períodos clássicos da comunidade greco-romana, que a escravidão era, em tempos arcaicos, formas de servidão ao lado do trabalho escravo ${ }^{18}$ que ainda não ganhara seu feitio final: o indivíduo não estava efetiva ou totalmente privado de liberdade. Isto, por sua vez, reforça nossas considerações de que o cativo-mercadoria será, sem dúvida, o pilar sobre o qual se assenta a cidade-estado ateniense, sua economia e possibilidades. Ocorre, portanto, o desenvolvimento da propriedade privada móvel, sua dimensão impessoal que permite o comércio e uso de sua força de trabalho nos mais diversos domínios e regiões geográficas do mundo helênico. Decerto, o escravomercadoria é responsável , também, pelo sucesso e extensão do império ateniense, a partir de 478, com a liga Délica. Retomaremos, mais adiante, estas considerações.

Vejamos, na seqüência, e para além das formas de trabalho, outras dimensões do oikos aristocrático, com o que se dá maior profundidade à sua dinâmica interna, e assim, portanto, à conformação que se instituirá na Grécia clássica.

17. Perry ANDERSON, Passagens da Antigüidade ao Feudalismo, p. 21-2.

18. Sem esgotar a complexidade do tema, o que parece é que o trabalho escravo se torna efetivo pela inserção do escravo-mercadoria, ou seja, do indivíduo privado de liberdade, vendido nos mercados em oposição ao cativo servil que só excepcionalmente era vendido; tal distinção é, segundo Anderson, a matriz que distingue as formas servis, da escravidão clássica; assim, Anderson se expressa acerca da época clássica no livro citado: "o uso da escravatura se tornava geral, a sua natureza tornava-se absoluta: já não era uma forma relativa de servidão entre muitas, ao longo de um continuum gradual, mas uma condição polarizada de ausência de liberdade", (ANDERSON, op.cit., p.23) 
Vários são os limites do oikos. Finley, em O Mundo de Ulisses, pontua um dos traços mais peculiares ao mundo homérico. Em determinado passo, considera:

\begin{abstract}
O mundo de Ulisses estava dividido em numerosas comunidades mais ou menos semelhantes às de Ítaca. Entre cada uma e todas as outras, o modo normal de relações era a hostilidade, por vezes passiva, uma espécie de trégua armada - por vezes ativa e belicosa /.../ Neste ambiente continuamente hostil, os heróis podiam procurar aliados; o seu código de honra não lhes exigia que enfrentassem sozinhos o mundo inteiro. Mas o seu sistema social não criava a possibilidade de concluir uma aliança entre duas comunidades, enquanto tais. Era necessário recorrer a arranjos pessoais pelo canal do estatuto doméstico e do parentesco. O primeiro instrumento de aliança era o casamento; entre outras coisas, ele servia para estabelecer novos ramos de parentesco; ele instituía assim essa rede de obrigações mútuas que se entrecruzavam através do mundo grego /.../ A prossecução, durante várias gerações, deste comércio bem calculado das filhas, desta troca equilibrada das mulheres, criava uma rede complexa, por vezes até um pouco confusa, de obrigações recíprocas. É uma das razões pelas quais os heróis, com o maior cuidado, aprendem de cor a sua genealogia e a recitam em muitas ocasiões. ${ }^{19}$
\end{abstract}

O que, de imediato, se pode tomar da letra de Finley é o fato de que as relações de hostilidade entre as famílias parecem denotar, acima de tudo, fraqueza estrutural do oikos. A hostilidade e a propensão para a guerra denunciam os mecanismos de reprodução dos clãs, isto é, um baixo padrão comunal, em que apenas defesa e conquista - de bens e riquezas - significa a possibilidade de continuar existindo, de se reproduzir nas dimensões acanhadas, e que não se ampliam, do oikos. Trata-se, portanto, não de uma hostilidade ou coragem meramente guerreiras de valores intrínsecos aos indivíduos; mas, de pronto, de condições históricas desfavoráveis que impelem os indivíduos a uma incontornável postura aguerrida que, não temendo o confronto, defende até a morte as aquisições e bens que permitam a vida dos clãs, das famílias.

Ainda da reflexão citada, sustenta-se a idéia de que no oikos a articulação e o compromisso, entre os diversos clãs, operavam-se a partir das relações de parentesco, sendo que o casamento os unificava, permitindo a cooperação entre as famílias envolvidas. Dessa forma, o casamento fortalecia as possibilidades de reprodução do oikos, pois aumentava o número de pessoas que participavam das engrenagens reprodutivas do clã, desde sua defesa até a pilhagem. Sobre as relações interclãs por hospitalidade, Finley dispõe que são relações que salientam a debilidade estrutural do oikos, o qual depende-

19. M. FINLEY, O mundo de Ulisses, p. 147-8. 
ria, para sua sobrevivência, em algum momento, do estabelecimento de conexões que fortaleceriam, ou ao menos dariam sobrevida a uma ordenação social que dificilmente se perpetuaria apenas a partir de suas próprias forças, que, pelos “técnicos” vínculos da hospitalidade, poderiam se amparar reciprocamente:

As relações de hospitalidade constituíam uma instituição muito séria para o estabelecimento de vínculos entre chefes, rivalizando com o casamento /.../ Hóspedes e vínculos de hospitalidade eram bem mais do que a expressão sentimental de uma afeição humana. No mundo de Ulisses, tratava-se de termos técnicos que serviam para designar formas muito concretas de relações, implicando direitos e deveres tão formais como o casamento. ${ }^{20}$

Ora, o valor da hospitalidade, a forma como os reis ou chefes do oikos acolhiam o outro, remete-nos a uma malha intrincada de aspectos, na qual o estrangeiro - o chefe do outro oikos - é visto necessariamente com reservas, como inimigo em potencial. Pela criação de laços de hospitalidade, então, atenuam-se eventuais discórdias, como também se promovem alianças que, de outro modo, não se dariam. Em outros termos, a hospitalidade significava - e os presentes trocados bem o ilustram -, uma forma distinta de aquisição e de alianças que, direta ou indiretamente, proporcionavam a adquirição de bens vitais, bens que, por outros meios, seriam inacessíveis, inconquistáveis. De modo que assim se afigura o quanto o oikos era uma forma comunal fechada, isolada face ao mundo exterior, cuja economia de subsistência lhe impossibilitaria um intercâmbio com outros clãs. Ou melhor dizendo, num mundo onde o oikos nada produzia para além de suas necessidades imediatas e no qual o estrangeiro era visto com reservas, pois a pilhagem era, sem mais, o modus operandi essencial dos tempos homéricos, a hospitalidade nascia como atributo social vital - "bem mais do que a expressão sentimental de uma afeição humana”. De modo que o comércio, e não poderia ser diverso, possuiria dimensão secundária em tal formação social, como expressa Finley:

Na Odisséia o comércio diferia das múltiplas formas de prestação de presentes, no que a troca dos bens constituía aí um fim em si. No comércio os objetos mudavam de mãos porque cada um tinha necessidade do que o outro possuía e não, ou somente de maneira acessória, para compensar um serviço prestado, selar uma aliança ou assentar uma amizade. A necessidade de um objeto

20. M. FINLEY, O mundo de Ulisses, p.149-50. 
determinado era a finalidade da transação; se ela podia ser satisfeita por outros meios, o comércio não era absolutamente necessário. ${ }^{21}$

Em tom diverso da época clássica, portanto, o comércio comparece de forma essencialmente marginal; o intercâmbio entre as unidades familiares é quase inexistente o que se põe é uma produção de valores de uso para satisfação imediata. Por outro lado, a ausência - quase completa - da atividade mercantil pode ser aferida ainda pelo baixo nível produtivo, e, em segundo lugar, pela ausência do instrumento próprio ao comércio - o dinheiro, a moeda, mediador do intercâmbio entre os homens. Em reflexão desdobrada:

O gado era a unidade de medida do valor dos bens, relativamente a isto, e neste sentido apenas, 0 gado nem o que quer que fosse preenchia as funções que foram mais tarde do dinheiro. Sobretudo não havia nenhum intermédio cuja única função tivesse sido, como no caso da moeda, tornar a compra e a venda possíveis pela circulação de mão em mão. Quase não importa que objeto de uso servia para esta função, e é necessário notar que a unidade de valor, o gado, não desempenhava, ela própria, a função de meio de troca /.../ Em si mesma esta medida não pode determinar o quanto de ferro ou de vinho equivale uma vaca. ${ }^{22}$

De maneira que nos tempos homéricos, o gado - por sua importância e relevância na economia familiar - assume, sob forma genérica e imprecisa, muito mais como intenção, o balizar das trocas, pois em economias pastoris não existiam as condições para a troca eqüitativa entre produtos. De fato, tais intercâmbios se operavam pela pura e simples necessidade, situação que demonstra que o valor e a troca eram categorias extrínsecas ao oikos; categorias não vividas porque não contempladas pela forma de produção familiar. Linhas à frente, Finley elabora uma reflexão sobre a inexistência do valor, reflexão muito oportuna a este momento argumentativo:

\footnotetext{
No mundo de Adam Smith esta determinação [do valor] fazia-se através do mercado da oferta e da procura, mecanismo completamente desconhecido em Tróia ou em Ítaca. Atrás do mercado esconde-se o móbil do lucro; ora, se havia alguma coisa tabu nas trocas homéricas, era certamente o lucro na troca. O princípio imutável tanto no comércio como em qualquer outra relação mútua era a igualdade, a mútua vantagem. O ganho realizado às expensas de outrem relevava de um outro domínio, da guerra e da pilhagem, onde se efetuava por atos de bravura (ou por ameaças) e não pelo ágio e pela mercancia. As conseqüências de uma taxa de troca fixada pelo costume e
}

21. M. FINLEY, O mundo de Ulisses, p. 95.

22. Ibid., p. 95-6. 
convencional parecem inevitáveis. Quer dizer que não existia autoridade institucional capaz de decretar uma escala de valores: tanto de x por tanto de Y. Mais exatamente, a prática efetiva de trocas estendendo-se por um longo período de tempo tinha fixado as proporções, e elas eram geralmente conhecidas e respeitadas. Mesmo na repartição do saque que o chefe do oikos, rei ou comandante em chefe, dirigia, representado a autoridade central, este último era evidentemente obrigado a respeitar as normas geralmente consideradas como eqüitativas. ${ }^{23}$

O que se extrai, e uma vez mais, da argumentação determinativa de Finley, é a dimensão limitada da orgânica social do oikos, o que se entrevê na exata medida em que as trocas deveriam se pôr num patamar de equilíbrio e de igualdade, isto é, de uma proporção simplesmente capaz de zelar pela reprodução dos clãs, atendendo, em limites factíveis, imediata e unicamente, às necessidades do oikos. É provável que a própria fragilidade ou limite do oikos fornecesse a medida para as trocas, isto é, o chefe do oikos cederia até determinados níveis (considerando o seu interesse), desde que a forma e medida das trocas não gerassem perturbações e instabilidades no oikos. Em verdade, estamos diante de uma economia essencialmente pastoril e de restrito cultivo da terra, sem espaço para a mercancia, que pressupõe efetivo excedente. Assim, a economia do oikos é de caráter predominantemente extra-econômico, isto é, sua reprodução era garantida a partir de mecanismos, em sua maioria, não produtivos - pilhagens, presentes, alianças -, obtidos, pois, não por meio das forças de produção essencialmente econômicas. No máximo, encontramos no oikos um uso pobre da terra, especialmente pastoril e de cultivo um tanto escasso, como assinalam as palavras de Austin e Vidal- Naquet:

os nobres guerreiros são, antes de mais nada, proprietários rurais. Desde Homero que encontramos a concepção da agricultura como fundamento da civilização. A terra é explorada por todas as formas: agricultura, culturas arbustivas (vinhas, olivais, árvores de fruto), culturas hortícolas, mas é na verdade a economia pastoral que predomina. A riqueza dos grandes chefes contar-se-á, sobretudo, pelo número de cabeças de gado, principalmente de bois. ${ }^{24}$

Finley reforça a determinação: "A base do oikos era a terra. /.../ A terra servia principalmente para pastagens /.../ o mundo de Ulisses era o de pastagens e não o da lavra". ${ }^{25}$

23. M. FINLEY, O mundo de Ulisses, p. 96-7.

24. M. AUSTIN \& P. VIDAL-NAQUET, Economia e sociedade na Grécia antiga, p. 51-2.

25. M. FINLEY, O Mundo de Ulisses, p. 84. 
Eis, pois, o espaço adscrito da atividade econômica: grosso modo, o pastoreio e, ao mesmo tempo, o acúmulo de bens que advinha das guerras, alianças e trocas eventuais, de sorte que o papel capital da dimensão extra-econômica na vida do oikos não deve ser minimizado. Vale dizer que

havia uma outra forma de se conseguir tudo aquilo que pudesse faltar: as expedições de pilhagem. Os heróis [homéricos] não se acanham em recorrer a tal expediente no intuito de assim se apossarem de animais, de mulheres, de metais preciosos ou de ferro ${ }^{26}$.

As pilhagens, pois, tinham um intuito muito preciso: a aquisição de bens, mão-de-obra e metais para as necessidades do oikos e não, salvo casos específicos, a aquisição de novas terras. O oikos, diferentemente do que ocorrerá na cidadeestado, não permitia grandes apropriações para além de limites estreitos, pois estes seriam conquistáveis a partir de suas próprias forças e possibilidades, o que significa que a comuna do guerreiro era fruto de um momento de desenvolvimento da propriedade privada e a mesma não poderia se expandir, como aconteceria, futuramente, nos processos de colonização e aquisição de novos territórios por meios políticos e militares.

De fato, a satisfação mínima das necessidades era a essência e marca do oikos. Tal determinação pode ser entrevista a partir do tipo predominante de atividade exercida pelo escravo, que Finley ${ }^{27}$ desenha: “o que se efetiva é uma atividade de caráter fortemente doméstico, com incursão fundamental pelo pastoreio”. Aqui, e diversamente da época clássica ateniense, o trabalho é pouco diversificado, evidenciando assim a diminuta relação de transformação com a natureza e os poucos recursos que os homens dispunham para tal objetivo. Posto sinteticamente: as forças produtivas assentadas num patamar mínimo de desenvolvimento engendram um homem cuja criação do próprio mundo não pode superar patamares limitados, mundo que, frágil em seu equilíbrio precário, impede o curso de sua reprodução e desenvolvimento. Esta forma de produção, então, se põe como barreira a qualquer desenvolvimento ou particularização das formas de trabalho, pois, em tais condições, faz-se radical impossibilidade, de modo que é intrínseco ao oikos limites evidentes que interditam sua ampliação e reprodução. Por isso, a dissolução do oikos significou, no mundo grego, a emergência da cidade e, posterior-

26. c. MOSSÉ, A Grécia arcaica de Homero a Ésquilo, p. 72.

27. O mundo de Ulisses, pp. 82-4. 
mente, da pólis, plena de riquezas, mas também de misérias e contradições, cujo ápice século V - faria, contraditoriamente, aflorar suas próprias debilidades. Para esta nova orgânica social, o texto ora se volta.

\section{Da pólis.}

O século VI marca o nascimento da vida pública, do poder político encarnado em suas formas específicas, da vida citadina em oposição ao caráter essencialmente patriarcal, pessoal e não político do chefe do oikos. Mossé, ao assinalar o nascimento da pólis cívica, afirma:

Uma cidade grega era geralmente constituída por um centro urbano, na maior parte dos casos, próximo do mar, e por um território mais ou menos vasto /.../ não havia divisão entre a cidade e o campo, sendo a cidade essencialmente o centro político e religioso de uma comunidade de homens que viviam, sobretudo, dos proventos da terra /.../ Mas a originalidade da cidade grega não se resumia a isto. Residia, sobretudo, no fato de no seio desta comunidade as decisões serem tomadas na presença de todos, embora na maior parte dos casos se tratasse unicamente de aprovar o que era proposto por uma minoria cujo poder advinha da riqueza, da força militar e da autoridade religiosa. ${ }^{28}$

Em contraste esclarecedor, Finley afirma o caráter pré-político do mundo homérico, ao revelar a ausência do poder político comunal em a

/.../sociedade que transparece na Ilíada e na Odisséia é formada por reis e nobres, possuindo muitas terras, muitos rebanhos, e levando uma vida de esplendor e guerras. A casa senhorial era o centro das atividades e do poder. O rei era juiz, legislador e comandante. Não estava sujeito a controles formais, mas dependia da sanção das suas proezas, da sua riqueza e alianças. Um rei fraco não resistia por muito tempo à competição de rivais poderosos ou de inimigos externos. Não possuía um 'estado' ou 'comunidade’ que fosse seu suporte e apoio como questão de direito ou tradições. Não que este fosse propriamente um mundo da selva: havia cerimônias, rituais e convenções, pelas quais os homens se regiam. ${ }^{29}$

28. C. MOSSÉ, O cidadão na Grécia antiga, p. 9-10.

29. M. FINLEY, Os gregos antigos, p. 19-20. 
A oposição dos tempos é evidente: no oikos, o exercício do poder é pessoal, sem ter por suposto a relação prévia e o intercâmbio com a comunidade. Ao revés, o poder propriamente político da pólis cívica objetiva-se, sem mais, pela emergência de uma nova figura histórica: a comunidade dos cidadãos.

O século VI marca o nascimento do cenário político ateniense pela emergência da comunidade cívica, da intensificação dos problemas agrários e da arbitragem de Sólon. A exasperação dos conflitos da terra contrapondo o pequeno e o grande proprietários, são a rigor, o prenúncio de processos permanentes e irreversíveis no quadro do desenvolvimento da pólis ateniense. Num tal contexto, o que se evitou, não sem dificuldades e pela mediação de Sólon, ressalte-se, foi a própria autoconsumação da pólis já em seus primórdios; autoconsumação latente posta por impulsos nascidos de sua orgânica intrínseca, interna, ou de uma gênese notadamente limitada. Dito de outro modo, e num patamar mais geral: com Sólon, a política não restaurou apenas os traços mais característicos de uma comunidade que se desordenara, pois o pequeno camponês que sempre viveu em condições de extrema pobreza assim continuou, mas de pronto sancionou, através das leis, a substituição gradual da escravidão por dívidas pelo escravomercadoria. Nesse sentido, e isto é o que se deve sublinhar neste contexto, ao extinguir a escravidão por dívidas, Sólon testemunha e afirma o anacronismo de determinada forma de trabalho escravo, de sorte que sua substituição, paulatina, pelo escravomercadoria significou reordenação social de fundo, movimento que implicou na condição de sobrevivência de uma comunidade que, não obstante, não poderia ultrapassar perenes desequilíbrios e distorções. Ora, o que está em jogo, efetivamente, é o início da lenta, contraditória e descontínua substituição da propriedade da terra ainda dispersa utilizada essencialmente sob forma pastoril e no cultivo limitado, típico dos tempos arcaicos -, pela concentração da propriedade privada imóvel e de seu correlato: o escravo tornado mercadoria. O fato marcante da intervenção soloniana não é, frise-se, o de simplesmente corrigir uma injustiça - a escravidão por dívidas - na medida em que esta lhe é muito anterior. O que aflui é a possibilidade de instituir, por via jurídica, o fim do cativo por dívidas em função de sua substituição por formas de trabalho muito mais impessoais, desprovidas de amarras e de vínculos familiares, e, nesse sentido, de proveito muito maior para o proprietário: o escravo comprado nas praças. É preciso reconhecer, portanto, que o endividamento do pequeno camponês não é o único fator histórico forte que conduziu às reformas de Sólon, pois como havíamos assinalado, estas estão, primariamente, em consonância com o desenvolvimento e concentração da propriedade pri- 
vada do solo e do escravo-mercadoria. Finley ${ }^{30}$ ainda sugere que os empréstimos consentidos não visavam ao resgate da dívida ou ao enriquecimento do proprietário fundiário a partir de juros ou expedientes desta natureza. Em verdade, e isto é o que interessava ao proprietário, a pessoa, como garantia da dívida, tornava-se mão-de-obra para o trabalho na terra. Em outras palavras, o escravo por dívidas era, seguramente, um meio mais adequado (dadas as condições seculares de penúria do pequeno camponês) de se obter e manter, sob forma cativa, o trabalho para o cultivo da terra, obtenção, pois, que evitaria o expediente de pilhagem, este, mais custoso e arriscado. Ocorre, pois, que a intervenção soloniana representa, definidamente, os pródromos da concentração da propriedade fundiária na Grécia, a qual, de forma primordial e inequívoca, necessita, nas mais variadas regiões, de mão-de-obra; daí a presença incontornável do escravo, que, tornado mercadoria, poderia ser comprado e vendido sem nenhum impedimento ou constrangimento pelo seu senhor. Seguramente, o cativo tornado mercadoria é, em termos gerais, não mais do que uma forma aguda ou radical de escravidão, pois neste modo de trabalho o indivíduo perde toda e qualquer autonomia sobre si mesmo, sobre seus desígnios, tornando-se simples "matéria” nas mãos de estranhos, passível de uso em toda e qualquer atividade, urbana ou rural. E se assim o é, atina-se, imediatamente, com a observação de Finley que a propriedade tendia a se fazer maior e mais concentrada nesta quadra da história grega, isto é, se a escravidão adquire tais formas radicais de apropriação do indivíduo, esta situação é o testemunho de que o rumo grego na esfera econômica se fazia por via da privatização maior da terra, logo, considera o historiador:

/.../a tendência na antiguidade foi de um aumento regular da dimensão das propriedades; não uma simples linha ascendente, tanto uma acumulação de propriedades separadas, às vezes mesmo muito espalhadas, como um processo de consolidação; mas de qualquer maneira uma tendência contínua ${ }^{31}$.

Assiste-se, pois, ao processo de concentração da propriedade dispersa territorialmente, o que impõe a presença do escravo mercantil, isto é, daquele que poderia ser comprado e vendido sem impedimentos ou vínculos pessoais de qualquer natureza, facilitando, sobremaneira, a mobilidade e o transporte para trabalhar onde fosse conveniente. Processo que, por sua vez, está na base da formação e desenvolvimento da pólis ateniense, isto é, da unidade entre o urbano e o rural. Pólis que, por eixo central, corporifi- 
ca uma economia predominantemente fundiária, como esclarece pertinentemente Anderson $^{32}$ ao ressaltar o processo cujo ápice sintetiza a pólis madura: a unidade entre o urbano e o rural, com destaque simultâneo para a dimensão citadina e a economia predominantemente agrária. O que transparece em suas palavras é, de saída, o contraste aparentemente paradoxal entre o esplendor de força e possibilidades da vida citadina em oposição à dinâmica de talhe necessariamente adstrito, de uma economia pouco diversificada, limitada que, em última instância, tem no vinho, trigo e azeite seus esteios estruturais. Anderson aponta, portanto a bipolaridade, profundamente contrastante, que faz da pólis tanto o ponto de chegada de todo um processo avançador de afirmação da propriedade privada da terra e, imbricadamente a isso, o lugar de limitações econômicas - e humanas - de toda ordem, posto a predominância da dimensão rural da economia em detrimento de um comércio e manufaturas que se fazem marginais. Assim, o real brilhantismo da pólis grega está, até certo ponto, em contradição com suas próprias premissas materiais: a vida da urbe demandava - Atenas é exemplar - uma economia capaz de atender às suas possibilidades enquanto equação societária, mas não foi isto que ocorreu entre os gregos, pois as contradições e dilemas sociais ingênitos são sua alma que alimenta e reproduz, de forma amesquinhada, as cidades gregas do começo ao fim.

Inúmeros são os aspectos envolvidos na formação e desenvolvimento das cidades-estado gregas. Não é nossa pretensão, visto que ultrapassa os propósitos deste estudo, elucidar, passo a passo, o processo formativo da pólis grega. O que se pretende é realçar momentos significativos da orgânica da pólis ateniense e das razões de seu declínio. Chamar a atenção, quando necessário, para o contraste com Esparta, por sua importância e relevo nos destinos da história grega e, por último, ressaltar o interesse deste processo no ideário e nas reflexões de Aristóteles sobre a política, objetivo de nosso estudo.

Atenas é, sem dúvida, no mundo helênico, a cidade de maior expressão e eco históricos, pois, direta ou indiretamente, os destinos da comunidade grega se viram entrelaçados às suas próprias possibilidades e perspectivas. Atenas forjou, em tipicidade, o esboço contraditório e conflitante da unidade grega. Cidade que se impõe pela vontade das armas vê-se enfraquecida, de outro lado, por debilidades internas: a Guerra do Peloponeso, a imposição militar de Filipe, um quadro de progressiva destituição políticomilitar que marca o início de um processo lento e conflitante que, décadas mais tarde, porá fim à autonomia grega, em especial a ateniense. 
Anderson, nas páginas iniciais de Passagens da Antigüidade ao Feudalismo contorna, grosso modo, a lógica e a estrutura que permitiram a emergência da pólis clássica, notadamente Atenas. Pondera:

A civilização da antiguidade clássica representava /.../ a supremacia anômala da cidade sobre o campo dentro de uma economia predominantemente rural: antítese do primitivo mundo feudal que lhe sucedeu. A condição de possibilidade desta grandeza metropolitana na ausência de uma indústria municipal foi a existência de trabalho escravo no campo: só este podia libertar uma classe de proprietários fundiários das suas origens rurais tão radicalmente que ela pudesse transformar-se numa cidadania urbana que, apesar disso, retirava do solo a sua riqueza fundamental. ${ }^{33}$

Ora, o que Anderson coloca é, em suma, o nódulo explicativo da formação da pólis clássica: a escravidão como condição de possibilidade da vida citadina. O que ocorre é que a expansão do trabalho escravo, na condição de mercadoria, viabilizou a produção em todo território grego, universalizando a forma e o trabalho do escravomercadoria, pois, ao se constituir em mão-de-obra para o campo e a cidade, o escravo liberta parcela da comunidade para outras atividades, permitindo a emergência da vida citadina. O que está claro é que o cativo-mercadoria passa a ser, cada vez mais, força produtiva, visto permitir que a produção material se desloque como função da comunidade - em tempos primevos - para a esfera extracomunitária, ou seja, para indivíduos que assumem a produção na situação de não pertença da comunidade. Em outras palavras, na unidade familiar do oikos, o escravo pertencia à família e a produção e a reprodução do clã competia a todos; na emergência da cidade, da comunidade política, a produção e a reprodução da comunidade compete a indivíduos que não mais pertencem a ela, estranhos à comunidade e, por isso mesmo, em condições de permitir a ascensão daquele que não necessita mais realizar diretamente a sua reprodução, do citadino que assume outras atividades.

Finley, nos termos de uma síntese concernente ao mundo das relações de trabalho na pólis - terreno sobre o qual ora converge a argumentação -, mediatamente, corrobora a reflexão de Anderson:

/.../quanto mais avançada for a cidade-Estado grega mais se constatará ter havido nela a verdadeira escravidão, em vez de tipos 'híbridos' como a hilotagem /.../ de modo mais direto, as cidades nas quais a liberdade do indivíduo atingiu a sua expressão mais alta - muito obviamente Ate-

33. P. ANDERSON, Passagens da Antiguidade ao Feudalismo, p. 23. 
nas - foram cidades onde floresceu a escravidão na forma de bens pessoais /.../ o mundo prégrego - o mundo dos sumérios, babilônicos, egípcios e assírios (e não posso evitar acrescentar os micênicos) - era, num sentido muito profundo, um mundo sem homens livres, conforme o Ocidente veio a compreender este conceito. Era também um mundo no qual a escravidão na forma de propriedade pessoal não desempenhava nenhum papel conseqüente. Isso, também, foi uma descoberta grega. Característica da história grega, em resumo, é o avanço, lado a lado, da liberdade e da escravidão. ${ }^{34}$

Ora, é assinalada, em primeiro lugar, a própria condição de emergência da pólis ateniense: a reafirmação da presença do escravo-mercadoria como propriedade privada. Num segundo momento, para diferenciar dos outros modos de trabalho, Finley caracteriza o hilota como forma híbrida do trabalho escravo; atestando, para Esparta, a ausência da propriedade privada móvel. Ou seja, vale a referência, o cativo pertencia à comunidade, sendo, portanto, "propriedade coletiva do Estado" 35 . Significa dizer que

/.../a forma hilota manteve-se como uma 'forma pouco desenvolvida' de escravatura, já que os hilotas não podiam ser comprados, vendidos ou alforriados, e eram mais propriedade coletiva que individual ${ }^{36}$.

Contrastes entre formas de escravidão que, para Finley, implicavam diferenças profundas quanto às condições de direitos e de posse sobre si mesmo, quando descreve que:

categorias de trabalho compulsório, excetuando-se o escravo, possuíam, em graus variados, alguns restritos direitos de propriedade e, em geral, direitos muito maiores na esfera do casamento e da lei familiar. ${ }^{37}$

Evidencia-se que, ao contrário do escravo ateniense de tipo clássico, outras formas de trabalho cativo preservavam alguns direitos sobre o próprio indivíduo, tais como o interdito de compra e venda, direito de unidade familiar e, por vezes, alguma disponibilidade sobre a propriedade ou mesmo no atinente à esfera jurídica. Assim, a propriedade privada comparece, nos tempos não clássicos, ainda em sua dimensão de uso: direito de

34. M. FINLEY, Economia e sociedade na Grécia antiga, p. 122.

35. Cf. ANDERSON, P. op, cit., p.35.

36. Ibid., p.38.

37. . M. FINLEY, Escravidão antiga e ideologia moderna, p. 74. 
uso e não de alienação em relação ao escravo, configurando talvez mais uma posse do que uma propriedade. Em contraste nítido, o escravo de tipo ateniense, reitere-se,

é uma propriedade /.../ Os direitos de um proprietário sobre seu escravo-propriedade eram totais, em vários sentidos. O escravo, como tal, sofria não apenas uma 'perda total do controle sobre o seu trabalho' mas também do controle sobre sua pessoa e personalidade: o que há de único na escravidão, repito, é o fato de o próprio trabalhador ser uma mercadoria, e não meramente seu trabalho ou força de trabalho. ${ }^{38}$

Assim, assiste-se a um fenômeno no qual o cativo, nas suas modalidades, tornase estranho não somente à comunidade, mas também em relação aos frutos de seu trabalho, quer dizer: passa a vigorar uma apropriação da produção alheia pela comunidade; ora, o que emerge é uma apropriação da produção extracomunitária a partir e somente pela comunidade. Como o escravo é estranho à comunidade, a apropriação de seu trabalho e de seus frutos é algo natural, e mesmo necessário, como reprodução e lógica de uma vida que deixou o campo sem deixar suas raízes rurais. Inscreve-se uma vida urbana com produção rural, conquanto a cidade não dispunha dos meios de produção próprios da vida citadina, ou melhor, de uma produção organizada no interior da cidade o que, por sua vez, demandaria incremento produtivo e divisão social do trabalho e, dessa forma, uma urbe comercial, manufatureira ou industrial o que, para aqueles tempos, era pura impossibilidade. Daí, a fraqueza econômica estrutural que irá transpassar toda a ordem comunitária antiga e de tal forma que, e não parece desnecessário assim arrematar, para que a vida citadina subsistisse ocorre

/.../a conversão dos próprios homens em meios de produção inertes através da sua privação de todos os direitos sociais e da sua assimilação jurídica a bestas de carga. ${ }^{39}$

Em tal contexto e dinâmica, em que o escravo, como propriedade que é despossuída de toda e qualquer possibilidade social e individual, como ser despossuído de si, só poderia suceder a cisão entre cidadão e não-cidadão. Então, e em reciprocidade com este modo social, como já aludira Finley, na Atenas clássica, liberdade e escravidão se vinculam e respondem: o desenvolvimento da cidade, a criação de sua arte humanista, de sua cultura e vida cultural, bem como a invenção da política, pressupõem o desen-

38. M.FINLEY, Escravidão antiga e ideologia moderna, p. 77.

39. P.ANDRESON, Passagens da Antiguidade ao Feudalismo, p.24. 
volvimento da escravidão. Ou ainda, e ampliando a questão, a emergência e a concentração da propriedade da terra em unidades dispersas ao longo do território grego e, agregue-se a isto, o parco, mas significativo desenvolvimento do comércio e da manufatura, comparando-se com a situação sócio-histórica anterior, promovem em Atenas a necessidade de regulação das condições, limites, deveres e possibilidades do uso e fruto da propriedade privada. Por isso, a propriedade privada encontra no Estado, especialmente na esfera jurídica, a condição reguladora de seu uso e estatuto. Em verdade, a pólis, que se estrutura sobre uma agricultura privada circunscrita à qual se cola um comércio insuficiente e que então se lança, como maneira de se nutrir, em lutas pilhantes, embute, como condição sine qua non, a existência do Estado. Corpo social este que se objetiva enquanto mediador e artífice da “justa medida” socialmente reguladora - como promovedor do necessário “equilíbrio” sobre o qual Atenas se arrima, que implica a criação de um “justo termo médio” através do qual o equilíbrio social seja mantido. De modo que, num quadro de produção e reprodução sociais economicamente improgressivas a partir de dentro, de suas forças imanentes, a luta pelo necessário, e, por extensão, pela sobrevivência tende a se agudizar, de tal sorte que a disputa e a apropriação por outrem, de bens alheios, são possibilidades efetivas em tais situações. Num tal contexto, o Estado tem de interferir. E o faz, necessariamente, na reprodução do vigente, o que significa a arbitragem pela medida, pela “justa medida” entendida como valor e forma da convivência comunal, em verdade, como articulação limitada entre os indivíduos, pois o justo meio termo, frise-se, e como bem se argumentará a seu tempo, evoca a impossibilidade de se poder ir socialmente além, porque tal avançar sobre os limites concretos postos pela dinâmica da sociabilidade, arremessaria a vida à dramaticidade - pense-se, rigorosamente, no teatro trágico grego, no qual o "ir além de um justo limite" conduzido pelo herói, implica inexoravelmente em desgraça, sangue, tragédia. Daí, então, a necessidade, o valor e a força da política e da ética aristotélicas como mecanismos, no plural e no singular, de normatização das cidades-estado gregas.

\section{A pólis grega, em especial Atenas.}

Ao lado da lavra da terra, a cidade-estado incorporou novas atividades que, a seu turno, repõem ampliadamente a necessidade do escravo-mercadoria, pois a vida citadina acabou por demandar mão-de-obra para além do cultivo. Emerge, mesmo que topica- 
mente, uma pequena especialização das atividades produtivas, como assinalam Austin e Vidal-Naquet:

/.../encontramos escravos praticamente em todos os ramos da atividade ateniense, fazendo o mesmo trabalho que os homens livres: agricultura, comércio, artesanato, trabalhos domésticos, etc. Havia também escravos públicos afetados a diversas funções do Estado, escrivães, secretários, empregados das prisões; um grupo especial era dos trezentos arqueiros citas que serviam de polícia. O trabalho das minas era o único com tendência a ser considerado como uma atividade mais própria dos escravos, devido às condições particularmente duras em que era realizado. ${ }^{40}$

O que se afigura, pois, para além de uma economia fundiária é, diversamente dos tempos arcaicos, uma diversificação de atividades, mesmo que limitada, um certo incremento de especializações a partir da vida citadina. A singularidade da civilização grega reside, nesse sentido, na existência de um novo modo de vida, que inaugura patamares sociais mais complexos que o estágio histórico anterior: põe-se uma maior interrelação entre as individualidades. Dito de outro modo, o caráter diverso das atividades citadinas demonstra uma maior densidade da vida social, maior interação entre os homens, logo, maior possibilidade de se desenvolver e exprimir capacidades humanas, tendo-se como parâmetro os tempos homéricos.

Tal dinamismo da pólis, não obstante, retome-se o ponto central da argumentação, não contradiz suas adstringências de fundo, anteriormente manifestas. De fato, e esta é uma questão vital, a Atenas clássica irá alcançar a referencial capacidade humana helênica - tome-se a literatura, arquitetura ou filosofia -, no e pelo contraste com sua estrutura limitada, que se evolve não pelo incremento do interno, mas pela força da conquista guerreira das pilhagens. E esta forma comunal, que opera entre a exuberância e a impossibilidade de um desenvolvimento real e necessário, não casualmente, pois, fará do poder político e militar o lugar de sua expressão máxima em solo grego, período que, ao esgotar-se, leva consigo a epopéia maior dos gregos. Tomemos então, em alguns traços, este período da história grega antiga, a um só tempo apogeu e decaimento, com o que se conclui a construção do quadro histórico que, como moldura para a determinação da categoria da política em Aristóteles, este capítulo buscou delinear em linhas gerais.

Em primeiro lugar, é preciso referir que nesta quadra (séculos V-IV) se reconhece a intensificação da concentração da propriedade privada móvel e imóvel; em segundo, por decorrência, tem-se a maturação do quadro político ateniense, o que subentende, 
pelo menos tendencialmente, soluções políticas e jurídicas que privilegiam a emergência da democracia ou politéia, bem como a expansão, para além de suas fronteiras, do império ateniense. Assiste-se, ora, indubitavelmente, a um movimento de mão dupla: a consolidação da democracia dependia das soluções e do êxito do império ateniense; o império ateniense dependia da expansão da cidadania, isto é, do cidadão, proprietário da terra, para além das fronteiras de Atenas, de sorte que a democracia - enquanto expansão da cidadania - cria as condições de possibilidade e de domínio da pólis ateniense sobre outras cidades, uma vez que o cidadão ateniense torna-se, até certo ponto, cidadão grego, representante dos interesses do império ateniense em outras cidades, em outras localidades, expandindo a influência, o modo de vida e os interesses atenienses sobre as demais. Trata-se, seguramente, de um século - V - movente, regido pela identidade de dois focos simultâneos: as lutas, disputas e problemas internos da pólis; o sucesso e o fracasso da hegemonia ateniense sobre a Ática, as outras cidades e a própria defesa do território grego.

Os anos 480 a.C marcam definitivamente, para Atenas e o mundo grego, a intensificação da luta militar e política. Efetivamente, pelos próximos 150 anos, a guerra será realidade cotidiana. Das invasões persas até a morte de Aristóteles, em 322, a ação bélica se situa como centro das preocupações e atividades da cidade-estado; guerras estas que, postas e repostas, regulam e possibilitam a própria vida comunal. Informa Finley a esse respeito:

\footnotetext{
Calcula-se, durante o século e meio que decorreu desde o fim das guerras persas em 479 a.C. até ser derrotada por Filipe da Macedônia em 338, Atenas esteve envolvida em guerras numa média de duas a cada três anos, e nunca desfrutou de um período de paz de mais de dez anos consecutivos. Não é de admirar que a defesa da cidade estivesse na pauta da assembléia ateniense no mínimo dez vezes por ano. ${ }^{41}$
}

Em outros termos, a guerra tornou-se "endêmica, e mesmo 'natural', neste mundo"42. O que se vislumbra, pois, é que a vida vista por Aristóteles foi marcada pelos dilemas da guerra, e não em seu momento afirmativo e de sucesso, mas em seu revés, razão pela qual se pode falar de perda da hegemonia ateniense, e de uma franca incerteza sobre os destinos de Atenas, da Ática e da Grécia. Pontuando melhor, a reflexão aristotélica se insere num universo de fortes dilemas e perda de autonomia da cidade- 
estado. Pense-se, tão somente em Filipe, Alexandre e posteriormente em Roma. Vejamos.

Com a derrota dos persas em 478, surge um novo cenário geopolítico, favorável a Atenas e às suas pretensões hegemônicas. Estamos diante da liga Délica que, para Finley $^{43}$, objetivava a defesa das rotas do mar Egeu e, por extensão, dos interesses de Atenas e de sua defesa contra as invasões persas.

A Liga, de fato, é criada e se ergue como barreira, como defesa do território e dos interesses gregos, em especial atenienses, face às agressões externas. Nada mais natural que fosse Atenas a encabeçar tais propósitos, sendo a única, em sua época, a dispor dos meios necessários para o enfrentamento de problemas tão adversos. É certo que a Liga viria a constituir o primeiro passo do assim denominado império ateniense, ainda que o propósito primário fosse o forjar de um bloco cujas partes se respondessem em reciprocidade para fins militares. A pujança político-militar de Atenas força, não obstante, e de forma incontrastável, sua soberania e domínio sobre a Ática e demais cidades. Nos termos de Finley:

\footnotetext{
A Liga Délica foi, na história da Grécia clássica, o primeiro dos muitos casos importantes na manifestação do pan-helenismo, com ou sem esse nome, 'para justificar a hegemonia e o domínio de uma pólis sobre os outros Estados através da proposta de um objetivo comum, a guerra contra os bárbaros' ${ }^{44}$.
}

O que aparece, então, e isto se deve marcar, é o fato de que o império ateniense, tecido ao longo da história, não se formou a partir de intenções comerciais, mas, acima de tudo, por razões defensivas, para não permitir que outrem o subjugasse. O que estava em jogo centralmente, e não poderia ser diverso, eram as condições de sobrevivência, de sustentação e manutenção das limitadas condições materiais. E isto é revelador por si, pois tal situação distingue, uma vez mais, as adstringências da comunidade política grega, a saber: Atenas é levada a constituir o império ateniense não em função do desenvolvimento das forças produtivas, da expansão do comércio ou da manufatura, desenvolvimento que a conduziria, talvez, à necessidade de formação de uma rede comercial, mas, diversamente, posto o quadro de insuficiências e de recursos restritos, uma unidade - para a defesa e preservação do território. Por outro lado, tal unidade viabilizou

43. M. FINLEY, Economia e sociedade na Grécia antiga, p. 45.

44. Ibid., p.46-7. 
também, por meios militares, o saque e a pilhagem que, de modo direto, ampliavam as possibilidades de reprodução comunitária.

Por volta dos anos 440, temos o auge do império que subentende domínio coercitivo. Em relação ao fato, Anderson assinala que:

Em 440, no seu apogeu, o sistema imperial ateniense abrangia cerca de 150 cidades, principalmente jônicas, que pagavam uma soma anual em dinheiro ao tesouro central de Atenas e estavam impedidas de manter as suas próprias frotas /.../ A tributação total ao Império estava realmente avaliada em 50 por cento mais que o rendimento interno da Ática, e financiou indubitavelmente a superabundância cívica e cultural da pólis de Péricles. ${ }^{45}$

O que se observa, e vivamente, nesta co-relação de cidades, para além dos dispositivos de defesa e ataque é, indubitavelmente, a existência de uma economia centrada na arrecadação de impostos em regime anual e obrigatório. Em termos concretos, a Liga financiou com recursos extra-econômicos, ou ao menos contribuiu decisivamente no sentido de suster a produção e reprodução da democracia ateniense, bem como alavancou o sucesso, ainda que temporário, do império que se constituiu. De modo que a Liga Délica não se limitou ou se viu restrita aos desafios de defesa, de unidade e de integridade territoriais; diversamente, rompia como um instrumento poderoso pelo qual geravam-se recursos para os cofres atenienses, recursos que, sob forma de impostos, supririam as insuficiências estruturais de Atenas, que assim se autofinanciava. Século de ouro da democracia, que subentendeu a expansão da cidadania aos mais pobres, o pagamento de misthos, posta, em suma, a exuberante pólis do Partenon. A equação social ateniense, em tal contexto, se faz nítida, e vale aqui sintetizar: pela política, instituiu-se a não liberdade, a escravidão; no plano externo, o Estado impôs, a título de defesa territorial, um conjunto de obrigações que, diretamente subordinaram as cidades, impondolhes o tributo, que garantiu a vida de Atenas e de seus cidadãos.

E afora os tributos de cunho anual de Estado para Estado, Atenas impôs taxas sobre as terras dos súditos, como também ampliou sua cidadania através da expropriação de terras nos Estados-súditos. O que se vê, de forma ampla e organizada, é a constituição de um império de vassalagem: a guarda e a defesa das cidades participantes da Liga, por Atenas, em troca do envio de recursos à metrópole. Finley pontua esta problemática, afirmando o seguinte:

45. P. ANDERSON, Passagens da Antiguidade ao Feudalismo, p.44. 
o/.../tributo, em sentido estrito, é, naturalmente, apenas um meio de um Estado imperial drenar fundos dos Estados-súditos para seu tesouro. Provavelmente não é nem o mais comum nem o mais importante, se comparado, em particular, com o dízimo ou com a taxação monetária sobre as terras dos súditos. ${ }^{46}$

E mais adiante assinala, ainda, que é:

/.../na área do enriquecimento privado, e não público, que a terra desempenhava importante papel no império ateniense. O número de cidadãos atenienses, habitualmente das camadas sociais mais pobres, que recebeu lotes de terra confiscada ou, pelo menos em Lesbos depois da revolta malsucedida de 428, uma 'renda substancial e uniforme (e, portanto, arbitrária) equivalente a aproximadamente o pagamento de um hoplita durante um ano inteiro, decorrente das possessões mantidas e trabalhadas pelos habitantes da ilha, pode ter totalizado 10.000 no decorrer do período imperial. O tipo mais declarado de exploração imperial, portanto, beneficiava diretamente talvez de oito a dez por cento do total dos cidadãos atenienses. ${ }^{47}$

Ora, para além das taxas de Estado para Estado, a terra - no curso do império ateniense - cumpria a função de drenar recursos para a metrópole; por outro lado, a expansão da cidadania aos mais pobres, a partir da expropriação de terras e sua doação aos cidadãos mais pobres de Atenas, ampliava a porção da propriedade nas mãos de indivíduos privados atenienses, ou seja, o império ateniense criava a máxima concentração de riquezas do mundo grego e, simultaneamente, de concentração de propriedade privada fundiária. Desta feita, o proprietário privado ateniense se universaliza como condição de existência do próprio império ateniense, isto é, a terra ganha dimensão privada territorial, ou não se circunscreve mais, necessariamente, a uma órbita local, de modo que o cidadão de Atenas, como real protagonista desta cena, assumia expressão e importância sociais singulares em seu tempo: consubstanciava-se enquanto a categoria socialmente mais avançada e decisiva ao se firmar na condição da parcela mais rica, plena de possibilidades ou teleologicamente dominante, quer dizer: como individualidade que constrói, que aponta para o futuro mesmo que incerto e duvidoso. Assim, a democracia e o império atenienses corporificaram-se como respostas às demandas de equilíbrio, manutenção e continuidade da cidade-estado. Não obstante, mesmo em sua pujança, a Atenas do século V viria, progressivamente, a se consumar em problemas que, em 404, minariam, em boa medida, sua orgânica e possibilidades posto o fim simultâneo da guerra do Peloponeso e do império ateniense. Da mesma forma que o ano de 478 expõe as potencialidades de Atenas a partir de sua hegemonia no Egeu, o ano de 404 marca, de forma

46. M. FINLEY, Economia e sociedade na Grécia antiga, p.54.

47. Ibid., p.54. 
indelével, o fim do império ateniense, e, num sentido mais genérico, das próprias perspectivas gregas.

Por fim, a guerra do Peloponeso (431-404) se desenvolveu no interior dos já mencionados limites das cidades-estado. O curioso é que Tucídides refira-se a isto de saída. Mesmo que não atribua diretamente às adstringências estruturais da comunidade grega a fonte da guerra do Peloponeso, estas surgem implícitas em sua reflexão quando o autor menciona o temor como a causa capital da guerra. Dispõe Finley a respeito o seguinte argumento:

\footnotetext{
Em virtude da expansão de Atenas e do temor de Esparta, a guerra entre as duas cidades era inevitável, sendo uma questão menor a de saber se irrompeu em um ano em vez de em outro, por causa deste ou daquele incidente /.../ As guerras sempre existiram por causa do medo, conforme acreditava Tucídides no caso da guerra do Peloponeso /.../ O que havia a temer? A possibilidade de que outro Estado, pelo uso da força, procurasse invadir e assaltar algum território, ou conquistá-lo, subjugá-lo de uma ou outra forma. Essas possibilidades estavam longe de constituir temores imaginários /.../ em qualquer período da Antigüidade. ${ }^{48}$
}

De fato, Tucídides revela aguda percepção em sua análise, pois a despeito de uma consciência mais ou menos clara sobre as implicações subjacentes entre temor e guerra, a consideração do temor como motivação da guerra contém em si os limites e insuficiências econômicas estruturais dos dois lados envolvidos. Aquele que se expande e ataca, o faz pela possibilidade de ampliar os seus domínios, de expandir-se em virtude de uma insubsistência radical; assim, pode-se afirmar legitimamente, que o medo de não conseguir sobreviver por si, objetivamente, impele à guerra. Por outro lado, aquele que teme o ataque, teme, necessariamente, por suas próprias fraquezas, pela possibilidade de ser saqueado em seus diminutos bens e riquezas. De modo que o temor implica - e Atenas ilumina bem este processo - a necessidade de uma expansão antes que se seja surpreendido e vencido por um inimigo sempre existente em potência. Em suma, fazer a guerra significa, acima de tudo, estar vivo e lutar por sua sobrevivência no interior de um futuro sempre duvidoso. De fato, a guerra nunca resolveu os problemas em termos efetivos, e embora Atenas resplandecesse por suas conquistas educativas, artísticas e filosóficas, enfrentando desafios colossais, a pólis nunca deixou de ser um espaço pobre e de futuro incerto para larga parcela de sua população, logo insuficiente enquanto pers- 
pectiva para a própria democracia dos cidadãos. Na ponderação de Finley, encontra-se argumento definitivo acerca desta descrição:

Grande parte da população grega sempre esteve na posição crítica da subsistência marginal. Trabalhavam duro para ganhar a vida e não podiam ter esperança de melhorar sua situação econômica como recompensa por seus esforços: ao contrário, se houvesse algum tipo de mudança, era provável que fosse para pior. Fome, pestes, guerras, lutas políticas, tudo constituía ameaça, e a crise social era um fenômeno bastante comum na história da Grécia. ${ }^{49}$

Ressalta-se, pois, e genericamente, a pobreza estrutural da comunidade antiga, mesmo em tempos mais robustos, como no caso da Atenas clássica. Pobreza e dilemas que, ao fim da guerra do Peloponeso, sinalizam o remate do ápice ateniense:

A guerra terminou em 404, e a condição mais importante que os Espartanos vitoriosos puseram, foi a dissolução do Império. Por conseguinte, a guerra foi uma catástrofe não apenas para Atenas, como para toda a Grécia: desfez a única via possível para uma certa unificação política, embora, reconhecidamente, uma unidade imposta aos outros por uma cidade ambiciosa. ${ }^{50}$

O vácuo que nasce pela derrota imposta a Atenas por Esparta e a impossibilidade espartana de se pôr à altura dos desafios gregos remete, de novo, para as inviabilidades e dilemas da vida e da unidade gregas; o fracasso ateniense, e, em especial, o de Esparta em liderar uma coalizão política capaz de responder às urgências internas e externas, demonstra, em tipicidade, que o desequilíbrio nunca deixou de ser parte viva e permanente da história grega. Atenas dominou por 70 anos - embora não sem contrastes, e, ainda assim, mesmo nos seus melhores momentos, o império foi incapaz de ser resolvente quanto à pobreza secular; assim, a stasis incorporou o modo de existência grego, forma de ser da comunidade política grega, como revela Finley ${ }^{51}$ nas páginas de Os Gregos Antigos. Assim, o autor reconhece a agudeza de espírito presentes em Tucídides e Aristóteles: o que deve ser ressaltado é o fato de Aristóteles perceber a stasis como presença efetiva da vida citadina grega. Neste quadro, e isto tem de ser claramente expresso, Aristóteles vislumbra como mediação de uma solução possível a projeção da política e da ética, claramente da justa medida, pelas quais então se buscaria superar este quadro de agudas insuficiências. A stasis, diga-se, ganhou força e dimensão a partir

49. M. FINLEY, Economia e sociedade na Grécia antiga, p.112-13.

50. IDEM, Os gregos antigos, p.60.

51. Ibid., p.52. 
dos limites que impediam uma equação comunitária mais equilibrada, pois todo e qualquer desequilíbrio gera, ou pode gerar, conseqüências imprevisíveis. Finley, ao comentar sobre o aumento populacional e a inexistência de forças produtivas para suplantar o problema, chama a atenção para os expedientes extra-econômicos (a pilhagem, a migração, e os tributos) $)^{52}$ e o infanticídio ${ }^{53}$ de outro, como paliativos que visavam a equilibrar a comunidade sob limites. Ora, o aumento populacional sempre foi um problema para as comunidades de frágeis forças produtivas, de baixo ou nulo excedente. Nestes casos, recorria-se, quando necessário, ao infanticídio como forma de controle populacional. Efetivamente, o incremento da população não encontrava respostas satisfatórias face às demandas daí nascidas, incremento que gerava movimentos migratórios ou até mesmo provocava, embora em casos extremos, a guerra entre cidades. A própria produção, por energias ingênitas, pouco poderia se modificar, quando muito algum aumento inexpressivo da produção, fosse por aumento de mão-de-obra esporádica, fosse em função de melhores condições climáticas. De qualquer modo, e este é um ponto determinativo fundante, os limites da produção são evidentes e incontornáveis no mundo antigo, incluindo Atenas, ou seja,

\footnotetext{
É preciso lembrarmo-nos de que estamos a examinar a mais populosa cidade do mundo grecoromano daquele tempo /.../ forçada a importar regularmente dois terços do trigo, todo o ferro, estanho, cobre e madeira para navios, todos os seus numerosos escravos (exceto os criados localmente) e todo o marfim e pedras semi-preciosas, a maior parte das peles e do couro e uma vasta gama de bens (incluindo linho e papiro) essenciais a um alto padrão de vida civilizada agora já tradicional. ${ }^{54}$
}

Atenas, mesmo em sua singularidade, sofria de fortes restrições ou de incapacidade produtiva, pois, e as palavras de Finley atestam, que a Atenas clássica estava longe de atingir seus ideais autárquicos, ou de conseguir, por meios próprios, os bens necessários à auto-subsistência. A este respeito é oportuno aludir, ainda que de passagem, à curiosa lei ateniense que garantia ao cidadão, em primeiro lugar, o direito sobre a posse de alimentos; vale dizer, só ao cidadão é reconhecido e contemplado:

52. M. FINLEY, Economia e sociedade na Grécia antiga, p. 211.

53. IDEM, FINLEY, A economia antiga, p.146.

54. Ibid., p. 184. 
/.../o direito positivo /.../ ao suprimento de comida. Daí o fato de dois itens estarem regularmente na pauta da primeira reunião da assembléia em cada pritania, a defesa da cidade e o suprimento de trigo. ${ }^{55}$

Em termos mais concretos, não se sabia se haveria comida para todos, seja em função de uma produção insuficiente, ou porque uma calamidade natural, guerra ou mesmo uma eventual impossibilidade de importação poderiam sobrevir. Qualquer que seja o motivo, o fato é que tal lei denuncia, mesmo na Atenas clássica, os desequilíbrios e as agudas barreiras à estabilidade comunitária, pois, concretamente, a simples sobrevivência imediata era palco de disputa - de garantia jurídica, caso não houvesse alimentos para todos. Corroborando na mesma direção, Vidal-Naquet e Austin desdobram em argumentação especificadora as angústias nascidas da luta pelo abastecimento de trigo, luta, rigorosa, que levou Atenas a formular uma política-legislativa concernente, isto é, a política e o direito engendrando necessidades de regulamentação:

\footnotetext{
Dentre os diferentes comércios de importação, o do trigo ocupa um lugar particular /.../ Na época clássica, este comércio atinge um desenvolvimento importante em numerosas cidades gregas, e, sobretudo, em Atenas, onde o crescimento considerável da cidade no século $\mathrm{V}$ teve por efeito reforçar a dependência de Atenas em relação às importações de trigo estrangeiro. /.../ A preocupação de controlar direta ou indiretamente as fontes de abastecimento de trigo é um fator permanente da sua política /.../ Uma lei datada, sem dúvida, de meados do século IV proibia qualquer pessoa domiciliada em Atenas (cidadão ou meteco) de emprestar dinheiro a um navio que importasse trigo para qualquer outra cidade que não Atenas /.../ Uma outra lei mais antiga proibia igualmente que qualquer pessoa domiciliada em Atenas transportasse trigo sem ser para o Pireu, e dois terços da carga deviam ser vendidos em Atenas. /.../ O comércio de trigo é o único comércio que a lei ateniense procurava regulamentar deste modo: a única preocupação do Estado era assegurar a regularidade das importações e proteger os interesses dos cidadãos consumidores. ${ }^{56}$
}

Em resumo, na luta pela sobrevivência, à economia se atavam visceralmente, assumindo importância social vital, a política, as guerras e as alianças, que assim provinham a sociabilidade dos limites, vale a expressão: sociabilidade então reproduzida nos limites de água e pão, ou melhor, do vinho, azeite e pão. É por isso que a guerra se objetiva, na formação comunal grega, enquanto mediação - cotidiana - que permite, dentro de limites determinados, regular os fluxos de bens necessários à reprodução comunal; ainda, quando tais fluxos são interrompidos, a guerra surge como expediente ordinário a 
equilibrar as reservas alimentícias e de bens, impedindo, ou ao menos minorando, o desfazimento comunitário.

Delineado tal contexto, cabe indicar, ademais, que para além das leis sobre o trigo, a comunidade política dispunha de outros mecanismos jurídicos relevantes que visavam a assegurar e equilibrar economicamente as famílias, tais como as ordenações dos dotes e dos casamentos. Aqui, do mesmo modo como nos tempos homéricos, o dote aparece como intercâmbio regulador, pois na

/.../lei ateniense o dote não se tornava propriedade total do marido. Em certas circunstâncias, como a morte de uma esposa sem filhos, por exemplo, a parte do casamento tinha que ser devolvida a seu pai ou tutor. ${ }^{57}$

Quando, páginas atrás, nos referimos ao império da vassalagem, queríamos dizer que Atenas, através de seu império, organizava-se a partir de expedientes essencialmente não produtivos, como impostos, taxas, dotes que, diretamente, viabilizavam a reprodução comunitária; ou, no mínimo, ajudavam de forma substantiva em sua reprodução. Situação, de fato, que denota incapacidade de um auto-regular-se, de uma dinâmica substantivamente autárquica. Ora, o dote, ao evidenciar a existência de uma troca ou trânsito mercantil entre indivíduo e bens, assinala - de forma inequívoca - a fragilidade econômica humano-social do mundo helênico.

Do mesmo modo e na mesma direção, as leis sobre as dívidas evidenciam o mesmo dilema. Leis cujo rigor se deve marcar de saída:

O extremo rigor das leis da dívida é fato muito conhecido e presente em todas as sociedades primitivas e arcaicas (e freqüentemente muito mais tarde também, como o atestam as prisões de devedores), particularmente quando devedor e credor pertencem a classes sociais diferentes. ${ }^{58}$

Para além da lei, enquanto tal, que na Grécia significava, num sentido geral, assunção de bons valores ou condutas sociais, o respeito à dívida sempre implicou o compromisso de sua quitação por meio do trabalho cativo. Nesse sentido, tais pendências ganham a forma de um problema essencialmente prático, não ético, pois o modo como tais urgências eram resolvidas repercutiam imediatamente nas famílias e na própria comunidade. A dívida foi, em detrimento de outrem, condição sine-qua-non de sobrevi-

57. M. FINLEY, Economia e sociedade na Grécia antiga, p.69.

58. Ibid, p.166. 
vência para muitos, não somente daquele que possuía a pequena propriedade, mas do médio e grande proprietário, pois, em verdade, a dívida significava o uso da força de trabalho escravo em suas terras, como antes assinalado. Cumprir e pagar a dívida é, para os gregos, trabalhar; logo, reproduzir a comunidade e suas perspectivas.

Face, pois, a tantos elementos reciprocamente divergentes e contrastantes, contradições, não obstante, geradoras do específico tecido social ateniense, é que se pode apreender em dimensão mais ampla, veredicto de Finley, as possibilidades da comunidade grega ateniense. Assim considera, extensamente, corroborando a argumentação exposta ao longo deste capítulo:

\footnotetext{
Nem mesmo a Atenas do século quarto esteve isenta dos sinais do declínio geral. Os próprios comentadores políticos da época realçaram o fato de que, enquanto no século quinto, os chefes políticos eram e se esperava que fossem simultaneamente os chefes militares, de tal modo que entre os dez generais se encontravam geralmente as figuras políticas proeminentes (eleitas para o cargo devido à sua importância política e não por outro motivo), no século quarto, as duas faces da atividade pública, a civil e a militar, estavam separadas. Os generais eram agora soldados profissionais, muitos deles inteiramente fora da política ou da influência política, que, com freqüência, serviam soberanos estrangeiros como comandantes mercenários, tal como serviam a própria pólis. /.../ uma clivagem na responsabilidade dos membros da comunidade, que enfraqueceu o sentido de comunidade. ${ }^{59}$
}

Assim, os fundamentos que até então asseguravam a possibilidade da reprodução comunal, do espírito cívico, se separam: a vida política e a vida militar que, cem anos antes, foram responsáveis pela exuberância da pólis helênica estão, no século IV, em divórcio efetivo. A fragmentação entre vida militar e vida política pressupõe, como condição essencial, o declínio estrutural da pólis, pois a emergência da vida mercenária evidencia que a guerra passa a ser um meio de vida para o soldado, com soldos que os Estados não podiam mais prover dada a situação de crise. Por outro lado, e no interior desta dinâmica, a condição do homem público deteriorava-se, como indica Mossé ao caracterizar o enfraquecimento do demos ateniense:

/.../aspecto que primeiro nos atrai a atenção é o da demissão política do demos /.../ Os apelos angustiados de Demóstenes são o testemunho mais gritante dessa demissão do povo, que o orador não esquece de lembrar e de sublinhar. Essa demissão do povo, esse 'desinteresse' pelos negócios

59. M. FINLEY, Os gregos antigos, p. 78-9. 
do Estado podem ser explicados pela crise econômica e social que então o mundo grego atravessa e à qual Atenas, com efeito não escapa, não obstante o seu poder ainda real e seu passado. ${ }^{60}$

A dissolução parcial da força e da responsabilidade do demos ateniense, no século IV, não é algo a se estranhar, fruto que é da crise econômica, por influxos da guerra do Peloponeso que diretamente promoveu a devastação dos campos, a diminuição das trocas mercantis e da exploração das minas do Láurio ${ }^{61}$. No plano objetivo, então, a Grécia do século IV vivia a exasperação de guerras, o incremento populacional, a ausência crônica de recursos naturais, a implosão das alianças político-militares e a estagnação produtiva. Nada mais estava arrimado naquilo que os gregos julgavam normal, ou pelo menos em condições minimamente satisfatórias de reprodução social. Enfim, e com palavras corroborantes:

Os progressos ulteriores da escravidão, o surgimento de uma produção manufatureira artesanal separada da economia doméstica, o desenvolvimento, no seio dessas sociedades agrícolas, e, para retomar as próprias expressões de Marx, em seus interstícios, de um setor comercial, sempre limitado, a difusão da moeda, são alguns fenômenos que assinalam o surgimento de novas contradições, sua passagem para o primeiro plano. Essas contradições só poderiam nascer nas condições características da cidade. Mas, ao mesmo tempo, seu desenvolvimento coloca em questão o próprio quadro no qual elas aparecem. Aos olhos de Marx, a generalização da escravidão, a extensão dos intercâmbios internos e do comércio marítimo, a constituição de um setor comercial de produção, a concentração da propriedade fundiária desintegram as formas de propriedade do solo e as estruturas sociopolíticas que caracterizam a cidade como tal. ${ }^{62}$

O que brota da reflexão citada é o reconhecimento e determinação das condições de fundo pelas quais a comunidade ateniense entra em declínio; há a necessidade imperiosa de se manter o equilíbrio, pois mudança significa impossibilidade de absorção da alteração; logo, declínio comunal. Dito de outro modo, para que ocorresse a reprodução ordenada, a comunidade deveria manter o patamar de necessidades, riquezas, população e propriedade inalterados. Como isto não poderia se dar ad infinitum, a comunidade perde a medida, o que geralmente significa aumento, excesso ou falta das condições habituais, a comunidade se multiplica em inviabilidades. É neste contexto, portanto, que comparece a destituição parcial - assinalada por Mossé - do homem público, quer dizer:

60. c. MOSSÉ, As instituições gregas, p. 42.

61. Ibid., p. 40-1.

62. VERNANT, P.VIDAL-NAQUET, Trabalho e escravidão na Grécia antiga, p.71-2. 
o desequilíbrio da comunidade em seu conjunto cria as condições para que o cidadão, em épocas de crise, volte-se para afazeres estritamente domésticos, do sustento imediato. Por outro lado, como Vernant e Vidal-Naquet assinalam, a crise da pólis decorreu de sua expansão e, portanto, da negação de sua própria origem. Ao citar Marx, os autores concluem pela contradição entre o incremento do comércio e da manufatura e as antigas relações de riqueza e propriedade. O homem público que outrora defendia os ideais de equilíbrio e ponderação para a comunidade vê que os mesmos se tornam menos nítidos ou menos realizáveis; daí, talvez, o enfraquecimento e desinteresse pelos negócios públicos.

De modo que mesmo que Atenas tenha passado, em relação a outras cidades ou regiões, de forma menos dolorosa por entre os embates, já não tinha condições políticas, militares e econômicas para se reerguer como liderança num universo de contrastes efetivos e de conflitos permanentes. Em verdade, nenhuma cidade grega conseguiria mais se erguer isoladamente como solução para os dilemas de porte universal, dilemas que implicavam unidade. Em termos concretos, ou a Grécia encontrava uma equação que, sob a liderança de uma cidade-estado forte promovesse a coligação militar, política e fiscal do território como um todo, ou os gregos, separadamente e de forma independente, não conseguiriam - como não conseguiram - opor-se às pretensões de seus vizinhos. A exuberância da Grécia no século V é tributária da liderança e do controle, por Atenas, de parcela significativa do território grego, porquanto a única possibilidade para os helenos estava em sua unidade, que, a despeito dos limites e contradições imanentes, promovia condições de reprodução societária. Efetivamente, a própria condição de cidadesestado independentes significava, como se demonstrou, fraqueza produtiva, poucos recursos naturais, fragmentação política e, no plano militar, vulnerabilidade permanente. Ora, como existir e enfrentar os desafios em contexto castrador de possibilidades? A unidade que Atenas buscou foi, sem dúvida, e para aqueles tempos, o único caminho viável, a potência limitada que soçobrou, não pelas mãos de Filipe ou por suas qualidades pessoais, mas, acima de tudo, por inviabilidades intestinas que o império macedônico tomou como vantagem.

É este, pois, ao menos em termos gerais, o solo genético da pólis que Aristóteles herda como homem e pensador. Pólis ateniense que, simultaneamente - apoucada e gigantesca -, implicou, como se buscará delinear, a criação de um plano jurídico, político, que regulou, por uma ética do limite, a condição e condução humana, a um só tempo ampla e cidadã, e travada em suas possibilidades. 
Por fim, cabe ressaltar que o declínio da pólis - mesmo a ateniense - não significou o fim ou o seu desaparecimento do mundo antigo. Na realidade, e até mesmo paradoxalmente, o declínio da pólis significou a emergência da helenização, da expansão e influência da cultura grega, sua força e ascendência sobre outros povos e, sobretudo, sobre os povos que conquistaram militarmente o mundo helênico. Se, por um lado, o declínio da pólis ateniense significou a impossibilidade do domínio político e militar sobre o mar Egeu e as rotas comerciais do trigo que, para Atenas, eram vitais - por razões evidentes; por outro, o seu declínio e subsunção a outros povos intensificaram o contato entre culturas e, dado o patamar alcançado pela cultura helênica esta, por sua vez, torna-se influente em toda a civilização antiga.

O que ocorre, é que o declínio da comunidade política se assenta, as mais das vezes, na impossibilidade ateniense de repor - a partir de suas próprias energias - o domínio político e militar sobre o território grego, dando-lhe uma unidade política e viabilizando sua integridade territorial. Demóstenes - nas primeiras décadas do século IV como principal opositor ateniense a Filipe, põe-se numa posição de luta pela soberania de Atenas, contra as forças de Filipe em momento difícil e de agudas mudanças históricas. Em outras palavras, a Guerra do Peloponeso e posteriormente a vitória de Filipe marcam, não o fim da pólis grega, mas o declínio da influência ateniense sobre os destinos da vida grega, quer dizer: a unidade política do império ateniense que - no século $\mathrm{V}$ - viabilizou a expansão da democracia aos mais pobres e sua auto-subsistência enquanto comunidade política. Assim, em Atenas, Mossé confirma nossas considerações ao esclarecer o nódulo central do declínio ateniense:

Todavia, se o regime subsiste, a cidade mesma não é mais que o pálido reflexo daquilo que fora outrora. Efetivamente, até a morte de Alexandre, ela cessa, quase que completamente, de ter uma política externa independente, e não desempenha mais qualquer papel nas relações internacionais, limitando-se a saldar seus compromissos para com o macedônio. ${ }^{63}$

Em seguida, comparece a destituição da democracia ateniense - em processo lento e contraditório; note-se que o fim da democracia ateniense significa o fim da unidade grega e, por certo, da menor influência e peso de Atenas sobre os processos históricos da Hélade. Não obstante o regime democrático ter vigorado - com interrupções - até inícios do século III, o domínio macedônico acabou por lhe conferir um conteúdo pu- 
ramente formal, destituído do vigor e dinâmica que, no século $\mathrm{V}$, conferia ao cidadão a palavra e os direitos sobre Atenas e seu destino. Com a submissão ao império de Filipe, Atenas - mesmo que democrática - acaba por reger a cidade sob os olhos atentos dos generais e reis macedônicos que, indubitavelmente, amesquinharam o feitio democrático e a soberania da maior pólis grega. Ainda, frise-se, a própria democracia lutou por sua sobrevivência, pois inúmeras vezes foi abolida e restaurada em Atenas, quer dizer: nas lutas pelo poder, a força do demos ateniense viu-se limitada a interesses alheios, extrínsecos ao horizonte ateniense, subsumidos ao império macedônico.

No plano econômico, o século IV - no pós-guerra do Peloponeso - assiste-se a uma recuperação relativamente rápida, visto que a economia grega sempre esteve em patamares pouco desenvolvidos, estagnados, mais ou menos declinantes. Diga-se que a guerra apenas intensifica os já baixos padrões produtivos; em tempos de paz, a produção retoma seu curso normal, em níveis de maior produtividade. Assim, no que tange à produção e ao comércio, o declínio da pólis pouco modificou ou alterou os já modestos e estreitos padrões estabelecidos, pois o comércio sempre fora marginal e a produção nunca se pusera no patamar da tão almejada autarquia. De sorte que, a vida econômica prossegue em seus dilemas irresolutos, apoucada em seus fundamentos, à margem dos destinos gregos, pois a economia, neste contexto, não fora palco de disputas fundamentais, já que as riquezas territoriais eram extorquidas por meios extra-econômicos, quer dizer: por taxas, pilhagens ou guerras. Em outros termos, o baixo nível produtivo nunca permitiu uma disputa efetivamente econômica entre as cidades e/ou impérios; trata-se, portanto, de rivalidade por controle das rotas de abastecimento, notadamente de cereais e alimentos.

Por fim, o século de Aristóteles aparece como o século do desenvolvimento de certas fortunas não fundiárias, advindas do comércio e da usura. Mossé, em texto cita$\mathrm{do}^{64}$, afirma que a arte de enriquecer ganha força no século IV, como atividade não essencial ao modo de vida da comunidade política. O fato é que Aristóteles, na Política, desqualifica tais formas de se obter riqueza, condenando o comerciante e a usura como modos de aquisição não naturais, pois, e nisto a usura é exemplar - ela não visa à autosubsistência e ao bem da comunidade; conclui-se que o que se condena é a riqueza para fins de acúmulo pessoal e, de certa forma, de prestígio diante dos outros cidadãos. A medida, para alguns, deixa de ser a comunidade o que, para o estagirita, é temerário, 
porque só a justa medida - estabelecida pelo Estado e pela ética - poderia, talvez, recolocar a comunidade política em seus anos de glória e unidade política do século V. 


\section{A P Í T U L O II}

\section{TELEOLOGIA E LIMITE: PÓLIS, ESCRAVO E NATUREZA}

A teleologia ou a busca por um princípio capaz de explicar o sentido da natureza, sua orgânica, bem como sua essência e causa primeira é, desde os primórdios do pensamento filosófico, o modus operandi da subjetividade grega. Marca capital do fazer helênico em sua luta por compreender os traços distintivos da realidade em torno. Ora, a procura por um, dois ou mais princípios capazes de fundamentar e ordenar os nexos ingênitos da physis, bem como sua ordem genética e desenvolvimento sinalizam, desde cedo, o tom, o empenho e a direção da filosofia grega. Assim, de Tales a Aristóteles, de Sócrates a Platão, assistimos a um movimento da subjetividade que se emancipa lenta e gradualmente do senso comum, no ensejo de compreender a physis e seus atributos. Tomemos, pois, a Metafísica de Aristóteles: obra emblemática na elaboração e crítica destes princípios.

A título de esclarecimento, eis os eixos temáticos da Metafísica, dada a importância da obra, mas os quais não se pretende abordar em seu conjunto:

1. em termos epistemológicos: validade e possibilidade de um novo saber, a ciência do ser enquanto ser e a busca das causas primeiras;

2. da existência sensível dos seres e da possibilidade de um ser supra-sensível;

3. a identidade entre ser e substância;

4. dos atributos e qualidades das substâncias;

5. dos vários sentidos do ser;

6. crítica da filosofia anterior, notadamente Platão. 
Nosso esforço reside em demonstrar como Aristóteles é herdeiro de um tempo que o influência sobremaneira, que dizer: a Metafísica começa por reprovar a história do pensamento filosófico até Platão, tendo por centro o exame da categoria de causalidade. Dito diversamente, a história da filosofia grega sempre partiu, desde os jônios, da investigação de princípios e causas que demonstrassem a ordem e os fins da natureza. Ora, o próprio Aristóteles se insere neste processo ao criticar a filosofia pregressa, pois em Metafísica, [I, 983 b 10], é dito:

Os que primeiro filosofaram, em sua maioria, pensaram que os princípios de todas as coisas fossem exclusivamente materiais. De fato, eles afirmam que aquilo de que todos os seres são constituídos e aquilo de que originariamente derivam e aquilo em que por último se dissolvem é elemento e princípio dos seres, na medida em que é uma realidade que permanece idêntica mesmo na mudança de suas afecções. ${ }^{1}$

Ainda em outro trecho de Metafísica, [I, 985 a 15], a respeito dos primeiros filósofos:

Parece que esses, como dissemos, alcançaram só duas das 'quatro' causas distinguidas nos livros da Física, a saber: a causa material e a causa do movimento, mas de modo confuso e obscuro, tal como se comportam nos combates os que não se exercitam: como estes, agitando-se em todas as direções, lançam belos golpes sem serem guiados pelo conhecimento. ${ }^{2}$

Então, o que o filósofo nos revela é a busca por uma causa primeira, material cuja origem e fim determinam o devir dos seres. É claro, pois, o elo teleológico que perpassa as primeiras abordagens dos físicos sobre a natureza, isto é, existia uma identidade entre os princípios, os seres e seus fins, vale dizer: o princípio é simultaneamente a origem de tudo, a substância constituinte do ser e o meio ou processo pelo qual o ser se põe em devir. Todavia, ainda em Met. [I, 983 b 20 e 984 a], é dito: “esses filósofos não são unânimes quanto ao número e à espécie desse princípio. Tales, iniciador deste tipo de filosofia, diz que o princípio é a água /.../ afirma-se que Tales foi o primeiro a professar essa doutrina da

1. ARISTÓTELES, Metafísica, II, p.15.

2. Ibid., p. 23. 
causa primeira”. ${ }^{3}$ Outros, como afirma o estagirita, consideravam como causa primeira demais elementos naturais, ou seja, “Anaxímenes e Diógenes, ao contrário, mais do que a água, consideraram como originário o ar e, entre os corpos simples, o consideraram como princípio por excelência” ${ }^{4}$. E ainda, Heráclito considerou o fogo como princípio. Mas, foi Empédocles que juntou os quatro elementos simples; além da água, ar e fogo, considerou também como causa primeira, a terra. Assim, a causa primeira é matéria e a matéria é aquilo que pode ser observado e sentido pelos sentidos.

Em momento ulterior, comparece uma sorte de autores que enveredam por um caminho mais abstrato, menos empírico, isto é, não creditam apenas aos quatro elementos naturais o poder de causa primeira. Ao chamar a atenção para Anaxágoras, Aristóteles, [Met., I, 984 b 15], afirma:

quando alguém disse que na natureza, como nos animais, existe uma Inteligência que é a causa da ordem e da distribuição harmoniosa de todas as coisas, pareceu ser o único filósofo sensato, enquanto os predecessores pareceram gente que fala por falar. Ora, sabemos com certeza que Anaxágoras raciocinou desse modo. ${ }^{5}$

De fato, “os que raciocinaram desse modo puseram a causa do bem e do belo como princípio dos seres e consideraram esse tipo de causa como princípio do qual se origina o movimento dos seres”. ${ }^{6}$ A partir de então, a filosofia muda o foco do princípio, da simples materialidade a dimensões não sensíveis. De modo que, linhas à frente, o filósofo, [Met.,I, 984 b 25 e 30], assevera:

poder-se-ia pensar que foi Hesíodo o primeiro a buscar uma causa desse tipo, ou qualquer outro que pôs como princípio dos seres o amor e o desejo, como fez, por exemplo, Parmênides. Este, com efeito, ao reconstruir a origem do universo diz: 'Primeiro entre todos os deuses (a Deusa) produziu o Amor; enquanto Hesíodo diz: 'Antes de tudo existiu o Caos, depois foi a terra do amplo ventre o Amor que resplandece entre todos os imortais', como se ambos reconhecessem que deve existir nos seres uma causa que move e reúne as coisas $^{7}$

\footnotetext{
3 . ARISTÓTELES, Metafísica, I, p.17.

4. [Met.,I, 984 a 5], Ibid., p.17.

5 . Ibid., p.21.

${ }^{6}$.[Met.,I, 984 b 20] ,Ibid., p.21.

7. ARISTÓTELES, Metafísica, I, p.21-23.
} 
De modo que da unidade ou pluralidade de causas materiais ou não, a filosofia avança na direção de perceber que a própria realidade é mais complexa e, nesse sentido, demanda a formulação de princípios que forneçam um modelo mais adequado do conhecimento. Ora, tais princípios ou causas assumem a forma de elementos contrapostos e opostos, assim, em [Met., I, 985 a], acrescenta:

... evidente na natureza a existência de coisas contrárias às boas, assim como a existência não só da ordem e beleza, mas também da desordem e feiúra, e a existência de males mais numerosos do que os bens, e coisas feias em maior número do que as belas, houve outro pensador que introduziu a Amizade e a Discórdia como causas, respectivamente desses contrários. ${ }^{8}$

Todavia, as conclusões (nem sempre científicas) produzidas pela filosofia présocrática, parecem traduzir um reconhecimento gradual e difuso da realidade em torno, ou seja: um único princípio material não poderia explicar a diversidade da physis, daí a necessidade de novos princípios, mesmo imateriais.

Resta, pois, algumas considerações sobre os pitagóricos e Platão. Sobre os pitagóricos, Aristóteles em [Met., I, 985 b 25], assegura:

Eles por primeiro se aplicaram às matemáticas, fazendo-as progredir e, nutridos por elas, acreditaram que os princípios delas eram os princípios de todos os seres. E dado que nas matemáticas os números são, por sua natureza, os primeiros princípios, e dado que justamente nos números, mais do que no fogo e na terra e na água, eles achavam que viam muitas semelhanças com as coisas que são e que se geram - por exemplo, consideravam que determinada propriedade dos números era a justiça, outra a alma e o intelecto/.../e além disso, por verem que as notas e os acordes musicais consistiam em números; e, finalmente, porque todas as outras coisas em toda a realidade lhes pareciam feitas à imagem dos números e porque os números tinham a primazia na totalidade da realidade, pensaram que os elementos dos números eram elementos de todas as coisas. ${ }^{9}$

Note-se, uma vez mais, a busca por princípios condicionantes que estruturam e dão forma aos seres. Entretanto, a qualidade dos princípios se alteram, entre a matéria, a inteligência e os números, a filosofia pré-socrática se envolve num emaranhado de

\footnotetext{
8. Ibid., p.23.
}

${ }^{9}$. Ibid., p.27. 
problemas cuja solução é duvidosa e insuficiente, ou seja, o centro da preocupação é o mesmo, a unidade subjacente que enforma e constitui a realidade, sua causa primeira. O remate de cada autor ou corrente corresponde à própria impossibilidade de se encontrar uma solução pertinente, pois a interrogação acerca dos princípios de todas as coisas é, em verdade, um falso problema, logo insolúvel. Assim, mais do que soluções, encontramos discursos difusos, ordenados a partir de supostos teleológicos ingênitos à própria natureza, modo inicial de aproximação científica face aos fenômenos naturais.

Por último, resta a polêmica contra Platão, mais difícil e de constituição recorrente nas páginas da Metafísica. Assim, Aristóteles expõe em [Met., I, 987 a 30], suas considerações:

Depois das filosofias mencionadas, surgiu a doutrina de Platão, que em muitos pontos, segue a dos pitagóricos, mas apresenta também características próprias, estranhas à filosofia dos itálicos. Platão, com efeito, tendo sido desde jovem amigo de Crátilo e seguidor das doutrinas heraclitianas, segundo as quais todas as coisas sensíveis estão em contínuo fluxo e das quais não se pode fazer ciência, manteve posteriormente essas convicções. Por sua vez, Sócrates ocupava-se de questões éticas e não da natureza em sua totalidade, mas buscava o universal no âmbito daquelas questões, tendo sido o primeiro a fixar a atenção nas definições. Ora, Platão aceitou essa doutrina socrática, mas acreditou por causa da convicção acolhida dos heraclitianos, que as definições se referissem a outras realidades e não às realidades sensíveis. De fato, ele considerava impossível que a definição universal se referisse a algum dos objetos sensíveis, por estarem sujeitos a contínua mudança. Então, ele chamou essas outras realidades Idéias, afirmando que os sensíveis existem ao lado delas e delas recebem seus nomes. Com efeito, a pluralidade das coisas sensíveis que têm o mesmo nome das Formas existe por 'participação' nas Formas. No que se refere à 'participação', a única inovação de Platão foi o nome. De fato, os pitagóricos dizem que os seres subsistem por 'imitação' dos números; Platão, ao invés, diz 'por participação', mudando apenas o nome. ${ }^{10}$

10. ARISTÓTELES, Metafísica ,I, p.35. 
A realidade, frise-se, não é mais vista como simples natureza, ou seja, com os pitagóricos e Platão o sensível é posto como coadjuvante das Idéias ou Formas. Ora, as Formas exercem a função de causa primeira, pois o sensível é posto como participante da Idéia, e só existe nesta relação. De fato, “as formas são causas das outras coisas, Platão considerou os elementos constitutivos das Formas como os elementos de todos os seres". ${ }^{11}$ Com isto, parece claro o ideário filosófico até Platão: com diferenças efetivas, os vários autores centraram seus esforços na compreensão das causas primeiras e, nesse sentido, Aristóteles é, por certo, co-participante e herdeiro deste processo. De fato, a filosofia primeva examina apenas a physis, seus atributos e causas. Diga-se que a solução encontrada foi inicialmente simples, caracterizando um modo ainda pouco científico e parcial de conceber a realidade. Inflexão importante, põe-se com Sócrates e sua filosofia moral e, notadamente Platão, com sua filosofia da pólis. A physis passa a ser reconhecida em sua contextura não apenas natural, mas política, lugar onde o homem exercita sua vida e suas capacidades: a cidade. Então, ao criticar a filosofia de seu tempo, Aristóteles expõe o seu ideário, sua cosmologia e visão sobre a natureza e o homem. Os contrastes são nítidos, pois a teleologia aristotélica ultrapassa a velha dicotomia da physis conquanto movimento ou repouso ou, ainda, entre sensível e inteligível e adentra em dimensões propriamente humanas, pois o papel desempenhado pelo devir, pela mudança consiste não apenas no movimento (próprio da physis), mas na possibilidade de criação de um objeto (o trabalho) a partir da intervenção subjetiva. Assim, a teleologia aristotélica se desdobra em teleologia natural e teleologia do trabalho, pois a mudança encontra sua face comunitária, ou seja, a do feitio e realização de um bem. Voltaremos a este assunto mais adiante. Eis o modo com o qual o filósofo compreende a mudança em Metafísica, IV, [1010 a 15]:

De fato, o que perde algo conserva sempre elementos do que vai perdendo e, simultaneamente, já deve ser algo daquilo em que está se transformando. E, em geral, se algo está em vias de corrupção, deverá ter uma certa realidade. ${ }^{12}$

${ }^{11}$. ARISTÓTELES, [Met., I, 987 b 20], p.37.

12. Ibid., p. 169. 
Ou ainda em [Met., IV,1012 b 25]:

Com efeito, se tudo está em repouso, as mesmas coisas serão sempre verdadeiras e sempre falsas; no entanto, é evidente que as coisas mudam/.../Se, ao contrário, tudo está em movimento, nada será verdadeiro e, portanto, tudo será falso; mas foi demonstrado que isso é impossível. Ademais, necessariamente, o que muda é um ser e a mudança ocorre a partir de alguma coisa e em direção a alguma coisa. ${ }^{13}$

Desse modo é superada a contrariedade entre repouso e movimento como estados irremediavelmente separados e contrapostos, característica da filosofia até Platão. Diversamente, Aristóteles observa que é intrínseco ao movimento a simultaneidade entre a perda e o ganho, ou seja, a realidade que muda realiza o processo num gradiente equilibrado entre aquilo que deixa de ser e aquilo em que se está transformando, ou melhor, no movimento não existe a perda e o ganho de atributos sob forma abrupta e imediata, pelo contrário, existe um movimento qualitativo e de equilíbrio entre as partes. De fato, o sensível não é mais visto como perpétuo devir, influxo perene, ou, como o lugar da imobilidade, da ausência de toda e qualquer mudança. Assim, a nova cosmologia aristotélica reordena o modo e a qualidade com que se estudam as causas e os primeiros princípios, pois a natureza é compreendida sob forma mais racional. Nas palavras de Reale em Introdução a Aristóteles, temos:

A distinção entre metafísica e física levará à superação definitiva do horizonte da filosofia dos présocráticos e suporá uma mudança radical do antigo sentido da physis, que, em lugar de significar a totalidade do ser, virá agora a significar o ser sensível, e natureza servirá para designar preferencialmente a natureza sensível. ${ }^{14}$

De fato, assistimos a um duplo movimento em Aristóteles: em primeiro lugar a recusa da forma e do tratamento da causa primeira até Platão; em segundo lugar, o reconhecimento do ser sensível dotado de movimento capaz de perder ou assumir novos atributos. Ora, isto eleva a discussão dos primeiros princípios para um patamar mais

\footnotetext{
${ }^{13}$. ARISTÓTELES, Metafísica, IV, p. 185

${ }^{14}$. G. REALE, Introducción a Aristóteles, p.69.
} 
objetivo. O ser não é mais tomado a partir de seus extremos, privado ou dotado de movimento perene. O movimento, em Aristóteles, ganha um reconhecimento equilibrado, eqüidistante tanto de Heráclito, como dos eleatas. Fica claro que, a partir desta nova cosmologia, o filósofo de Estagira inicia suas ponderações sobre a teleologia, as causas primeiras e a ciência que irá sustentar a possibilidade dos primeiros princípios. De modo que, em [Met., I, 982 b], Aristóteles afirma:

... a mais elevada das ciências, a que mais autoridade tem sobre as dependentes é a que conhece o fim para o qual é feita cada coisa; e o fim em todas as coisas é o bem e, de modo geral, em toda a natureza o fim é o sumo bem. ${ }^{15}$

Ora, o fim para o qual todas as coisas tendem é o sumo bem. Na natureza, o sumo bem significa o exercício pleno das funções; na ética, a aquisição de virtudes que permitam aos indivíduos a co-participação dos cidadãos na busca da felicidade; na política, o sumo bem é o bem da comunidade, da auto-subsistência que possibilita e potencializa as relações entre indivíduo e gênero. Em verdade, a teleologia é causa na exata medida em que é entendida como princípio que anima e possibilita a realização dos fins. Nessa linha de raciocínio, temos ainda em [Met., V, 1013 a 25-35]:

Causa, num sentido, significa a matéria de que são feitas as coisas/.../Em outro sentido, causa significa e forma e o modelo, ou seja, a noção da essência e seus gêneros/.../Ademais, causa significa o princípio primeiro de mudança ou do repouso/.../Além disso, a causa significa o fim , quer dizer: o propósito da coisa. ${ }^{16}$

Fica evidente, por meio da citação acima, que Aristóteles determina como causa algo múltiplo, multifacetado, pois a causa é vista não apenas como teleologia capaz de ordenar a natureza e o homem, mas como complexo capaz de explicar o conjunto do cosmo: a matéria das coisas, a mudança e movimento dos entes, da substancialidade ou essência, isto é: o princípio que enforma e determina o que determinado ser é. De fato, a causa é categoria central, pois implica o entendimento da natureza em seu todo e, nesse

${ }^{15}$. ARISTÓTELES, Metafísica, I, p.11.

16. Ibid.,V, p. 191. 
sentido, Aristóteles, vale repetir, é herdeiro da cultura helênica, da busca substancial dos primeiros princípios. De modo que vale aprofundar a explanação sobre o princípio das quatro causas em Aristóteles. É o que faremos a seguir.

A doutrina das quatro causas pode ser assim delineada: em primeiro lugar, temos a causa material; em segundo lugar, a causa formal; em terceiro lugar, a causa eficiente; por último, a causa final. No que se refere à causa material e formal, sumariamente, podemos afirmar que ao individualizar a matéria, a causa formal não apenas singulariza um ser sensível, mas também possibilita sua existência como ente concreto. Isto significa que a forma, ao enformar a matéria, predica-lhe uma essência, uma substância. Dessa maneira, para Aristóteles, a causa formal determina a essência das coisas e, nesse sentido, ao mesmo tempo o porquê das coisas. Em seguida, comparece a causa eficiente. Esta, por sua vez, permite o movimento ou a passagem da potência ao ato. Trata-se de um princípio movente que possibilita a atualização das coisas, bem como a corrupção das mesmas. No ser humano, a causa eficiente ganha dimensão particular, pois envolve a presença da subjetividade. Mais adiante será retomada a questão. Por fim, cabe frisar a importância da causa final: na Metafísica a causa final é compreendida enquanto princípio capaz de explicar a ordem, o movimento e a natureza em seu todo. Assim nas palavras do estagirita: “não é verdade que tudo esteja às vezes em repouso e às vezes em movimento, e que não exista nada de eterno. De fato, existe algo que sempre move o que está em movimento, e o primeiro movente é, por si, imóvel”. ${ }^{17}$ Ou ainda, "no âmbito dos seres, existe também outra substância, que não está sujeita de modo nenhum nem ao movimento, nem à geração, nem à corrupção”. ${ }^{18}$ Destarte, o que está posto é a possibilidade da substância movente imóvel, de um primeiro princípio imóvel capaz de ser o movente da physis sem ser movido por nada, e por isso, o movente imóvel (ou primeiro motor) é tido como causa primeira pois, segundo Reale:

Tudo o que é movido é movido por outro; esse outro, se é movido, é ainda movido por outro/.../Em suma, para explicar todo o movimento é preciso submetê-lo a um princípio por si não ulteriormente movido, pelo menos relativamente àquilo que ele move. De fato, seria impensável ir de movente em movente ao infinito, porque um processo ao infinito é sempre impensável nestes casos. Ora, se é

${ }^{17}$. [Met., IV, 1012 b 30], p. 185.

18. [Met., IV, 1009 a 35], p. 165. 
assim, não só devem existir princípios ou moventes relativamente imóveis, dos quais dependem os movimentos individuais, mas - e a fortiori - deve existir um Princípio absolutamente primeiro e absolutamente imóvel, do qual depende o movimento de todo o universo. ${ }^{19}$

Ainda, e como forma de adensar nossas considerações, cabe referir a física ou filosofia segunda, pois tanto a Física quanto a Metafísica buscam as causas ou primeiros princípios, com a diferença de que a primeira se atém ao universo sensível, a segunda adentra o plano do supra-sensível.

Na Física, o centro da investigação aristotélica recai para a compreensão do movimento da physis, de suas causas e finalidades. Aqui, o movimento na natureza é sempre um movimento teleológico, pois os seres sensíveis existem para cumprir, da melhor forma possível, seus objetivos. De fato, Aristóteles em [Física, IV, 208 b 15], exprime bem esta dimensão ao observar que

na natureza/.../com efeito, o alto não é um lugar qualquer, mas o lugar a que naturalmente são levados o fogo e o que é leve e, do mesmo modo, o abaixo tampouco é um lugar arbitrário, mas a direção a que naturalmente são levados os seres pesados e os corpos terrestres. ${ }^{20}$

Assim, a teleologia comparece, uma vez mais, como centro da physis, de sua orgânica e funcionamento. As dimensões, alto e baixo, põem-se numa relação teleológica, pois suas existências são reconhecidas na medida em que permitem a elevação daquilo que necessariamente se dirige às alturas, como também daqueles que obrigatoriamente ganham o chão. Em outros termos, a materialidade e as dimensões físicas interagem no sentido de que cada uma objetive suas funções, condizentes com as possibilidades da natureza, participando de sua lógica e harmonia.

Em outro momento, o centro da investigação recai para o exame do movimento: fenômeno capital que perpassa a substância sensível. Ora, na Física, Aristóteles analisa o movimento a partir de algumas premissas relativas à substância sensível: inicialmente, comparece o movimento de geração e corrupção este, por sua vez, implica uma nova qualidade, um novo estado do ser; assim, o movimento é compreendido como movimento

${ }^{19}$. G. REALE, Metafísica (Ensaio introdutório), p. 113.

${ }^{20}$. ARISTOTLE, Physics: The works of Aristotle, vol. I, p. 287. 
de atualização da substância ou, mais precisamente, da assunção de uma forma, da essência na direção de sua plenitude. De fato, Aristóteles desvela a força motriz do movimento: o princípio da causa eficiente, ou seja, o princípio de mudança, pois todo e qualquer movimento pressupõe uma causa capaz de gerá-lo e também a alteração qualitativa da substância. De fato, a polaridade em torno da mobilidade ou imobilidade dos entes foi resolvida a partir das categorias de ato e potência - modos de ser da substância - mudança para se tornar atual e cumprir a ordem teleológica. Todavia, afigura-se uma distinção importante no seio da teleologia em Aristóteles: a não presença da deliberação na physis, pois na Física

Aristóteles declara com ênfase que 'a natureza não delibera', portanto, a finalidade natural não é uma escolha racional e voluntária que as coisas teriam em vista de algo. Isso significa, em primeiro lugar, que Aristóteles, diferentemente de Platão, não admite uma alma no mundo e, em segundo, que Aristóteles demarca claramente a distinção entre a ação racional deliberada e ação natural, embora ambas sejam ações por finalidade. De fato, as ações da natureza, diz Aristóteles, são por necessidade, isto é, uma coisa natural é capaz de produzir sempre um só e mesmo efeito, ainda que o efeito possa ir de um extremo oposto ao outro extremo oposto que definem seu gênero. Ao contrário, as ações ou atos racionais são por vontade e, por serem deliberações voluntárias, são escolhas entre possíveis contrários e seus efeitos são múltiplos, variáveis de indivíduo para indivíduo ou num mesmo indivíduo, conforme as circunstâncias. ${ }^{21}$

Conseqüentemente, é nesta inflexão que o estagirita demarca bem as duas formas de teleologia, bem como as diferenças específicas entre homem e natureza. De fato, a teleologia, em Aristóteles, ganha dimensão particular pela presença da subjetividade o que, em termos concretos, significa um enorme avanço da filosofia no entendimento do homem e de seu mundo. Assim, na Física, I, [192 b 10] o estagirita, como que numa síntese, afirma:

Dentre todas as coisas que existem, umas existem por natureza, outras por diversas causas. Existem por natureza os animais e suas partes; as plantas e os corpos simples, como a terra, o fogo, o ar e a água/.../Pois todas as coisas que existem naturalmente parecem possuir, em si mesmas, um princípio de movimento e de repouso/.../Ao contrário, o leito e o vestido e qualquer outra coisa deste

21. . CHAUÍ, Introdução à história da Filosofia, p. 402. 
gênero/.../são produtos de uma arte, não possuindo nenhuma força interna que os impele à mudança ou ao movimento. ${ }^{22}$

Deste modo, "nenhum deles possui, em si mesmos, o princípio eficiente de sua própria produção; pois alguns seres o possuem em outros e fora de si mesmos; como por exemplo, a casa e qualquer outro ser que são fruto de uma manufatura ou uma fabricação" ${ }^{23}$

Fica claro, pois, o modo peculiar como o estagirita enfrenta o problema da natureza e do homem. Considerações que serão desdobradas a seguir.

\section{A inflexão da teleologia em Aristóteles.}

Em Política, a teleologia aparece não apenas como explicação subjetiva, isto é, da formulação de uma teoria ou hipótese plausível, mas como existência universal do cosmo, quer dizer, como modus operandi da natureza e da cidade. Ao comentar os momentos iniciais de Política, Ross afirma:

\footnotetext{
Aristóteles penetra imediatamente in medias res, afirmando que, como toda comunidade é formada em vista de um certo bem, o Estado, que é a comunidade suprema e que compreende todas as outras, deve visar ao bem supremo. O ponto de vista teleológico que ele adota é característico de todo seu sistema. $^{24}$
}

Portanto, a dimensão teleológica, como já afirmado, constitui um momento privilegiado da reflexão do estagirita, pois tanto a abertura de Política, como as linhas iniciais de Ética Nicomaquéia sinalizam que, em plena maturidade, a categoria da teleologia ainda é o modo de percepção vital para o autor, visto que todas as comunidades visam a algum bem (Política); e todas as ações, como também todas as artes e ciências visam a um objetivo qualquer (Ética Nicomaquéia). Vejamos.

\footnotetext{
22. ARISTOTLE, Physics: The works of Aristotle, vol. I, p. 268.

23. Physics, II, [193 a] Ibid., p.269.

${ }^{24}$. W.D. ROSS, Aristote, p. 328.
} 
Os estudos sobre a pólis ${ }^{25}$ desvelam, com clareza e ineditismo, a determinação do homem como animal político, como ser da comunidade. Revela distinções importantes no gradiente entre a pura animalidade (natureza) e a vida in communitas. Ora, ao compreender o homem como ente comunitário, a reflexão aristotélica reconhece o locus próprio do fazerse humano, em suma, do animal político citadino. Aristóteles, em EN, [I, 1098 a] ressalta o que é próprio ao homem ao declarar:

evidentemente, a vida é comum tanto aos homens, quanto às plantas; e nós procuramos o que é peculiar ao homem. Excluamos, portanto, a vida de nutrição e crescimento. A seguir há uma vida de sensações; mas essa também parece ser comum ao cavalo, ao boi e todos os animais. Resta, pois, uma vida ativa própria do ser dotado de razão; desta, uma parte tem tal princípio no sentido de serlhe obediente, e a outra no sentido de possuí-lo e de exercer o pensamento. E, como a 'vida do elemento racional' também tem dois significados, devemos esclarecer aqui que nos referimos a vida no sentido de atividade; pois esta parece ser a acepção mais própria do termo. Ora, se a função do homem é uma atividade da alma que segue ou que implica um princípio racional/.../se realmente assim é [e afirmamos ser a função do homem uma certa espécie de vida, e esta vida uma atividade ou ações da alma que implicam um princípio racional; e acrescentamos que a função de um bom homem é uma boa e nobre realização das mesmas; e se qualquer ação é bem realizada quando está de acordo com a excelência que lhe é própria; se realmente assim o é], o bem do homem nos parece como uma atividade da alma em consonância com a virtude, e, se há mais de uma virtude, com a melhor e mais completa. $^{26}$

Tem-se, em vista disso, um novo cenário da história do pensamento grego, no qual a teleologia é reformada, ou seja, de sua condição natural e necessária, compreendida como atributo de agentes naturais, passa-se à condição também de pertença e atributo dos homens, como razão ativa, interferindo, por vezes, nos desígnios naturais. Conquanto a razão se põe diferentemente entre os homens, isto é, uns a possuem para pensar e comandar; outros, para aceitar a condição de comandado. Então, o homem é compreendido como portador de uma faculdade capaz de construir uma vida com sentido.Em conseqüência, é assinalado um atributo próprio dos homens: o pensar e o deliberar. Em Metafísica, [V, 1013 b 5-10], lê-se que

25. Refiro-me aos textos políticos da maturidade: EN, CA e Política.

${ }^{26}$. ARISTOTE, Éthique de Nicomaque, p. 32-3. 
... tanto a arte de esculpir como o bronze são causas da estátua, e não da estátua considerada sob diferentes aspectos, mas justamente enquanto estátua; todavia não são do mesmo modo causas, mas uma é causa como matéria e a outra como princípio do movimento. ${ }^{27}$

Ou ainda, ao explicitar melhor as duas formas teleológicas em [Met.,VII, 1032 a 15]:

... gerações naturais são as das coisas cuja geração provém da natureza. Aquilo de que tudo se gera é o que chamamos matéria, aquilo por obra de que se gera é algum dos seres naturais; o que é gerado, enfim, é um homem ou uma planta ou alguma outra coisa como estas, que dizemos ser substâncias/.../Desse modo, portanto, ocorre o processo de geração das coisas geradas segundo a natureza; os outros processos de geração, ao contrário, chamam-se produções. E todas as produções ocorrem ou por obra de uma arte ou por obra de uma faculdade ou por obra do pensamento. ${ }^{28}$

Deste modo, [Met.,VII, 1032 b] por “obra da arte são produzidas todas as coisas cuja forma está presente no pensamento do artífice”. ${ }^{29}$

As citações acima revelam a presença de uma subjetividade atuante, capaz de conceber idealmente, de pensar o seu objeto, enfim, de idealizá-lo. De fato, Aristóteles distingue o que é obra da natureza (geração a partir das necessidades naturais), do que é obra do sentido humano. A produção é um ato intencional, reflexivo que demanda objetivos e conhecimento de algumas prioridades para o homem e sua comunidade. O homem não é mais compreendido como canga dos deuses, ao inverso, o homem percebe a razão em seu cotidiano, faculdade que une e confere um sentimento de comunidade. Tomemos, pois, as ponderações de Lukács firmadas na Ontologia do Ser Social ${ }^{30}$, em especial no capítulo dedicado à categoria do trabalho. Ao dispor sobre o labor em Aristóteles, o filósofo húngaro reconhece:

27. ARISTÓTELES, Metafísica, V, p. 193.

${ }^{28}$. Ibid., VII, p. 311.

29. Ibid., VII, p. 313.

30. Refiro-me à obra a Ontologia do ser social. Texto de maturidade, no qual onde o autor explicita, na medida do possível, os traços marcantes e decisivos do homem e da sociabilidade; estudo que esboça os nódulos de uma ontologia social que evidencia, a um só tempo, as dimensões ativa e reflexiva dos homens tendo, por norte, o resgate do caráter ontológico do pensamento marxiano. 
consiste em que um projeto intelectual se converta em realização material, em que a postulação pensada de um fim transforma a realidade material, introduz na realidade algo material que representa, frente à natureza, algo qualitativa e radicalmente novo. Isto é mostrado, de forma evidente, pelo exemplo aristotélico acerca da construção de uma casa. A casa é algo tão materialmente existente como a pedra, a madeira, etc. No entanto, no pôr teleológico surge uma objetividade totalmente diversa dos elementos. A partir do mero ser em si da pedra ou da madeira não é possível 'deduzir' uma casa por meio de um influxo imanente de suas propriedades, das legalidades e forças que nela atuam. É necessário, para isso, o poder do pensamento e a vontade humanas, que ordenam o material e, de modo factício, essas propriedades em um contexto, por princípio, totalmente novo. Nesta medida, Aristóteles foi o primeiro a reconhecer ontologicamente o modo de ser dessa objetividade que não pode ser imaginada a partir da 'lógica' da natureza. ${ }^{31}$

Então, o que Lukács ressalta é a sensibilidade aristotélica em reconhecer a intervenção subjetiva nos processos de produção, por outro lado, a realização do trabalho confere um novo status ao produto final pois, distinto da natureza, o produto é reconhecido como legalidade social, fruto dos influxos e necessidades da comunidade. Ora, toma forma um homem capaz de atividades cujos fins não são tão evidentes ou pelos menos bem mais imprevisíveis, pois desaparecera a certeza da legalidade natural. Desse modo, as cidades, na dimensão privada do oikos ou em sua condição pública, externam o locus enquanto espaço dos possíveis, do acaso, negação da teleologia natural.

\section{A teleologia, a cidade e a physis.}

O livro I de Política é rico em explanações sobre a teleologia, notadamente como dimensão ingênita da organização e dinâmica da cidade-estado. Assim, iniciemos nossas ponderações a partir das categorias de comandar e obedecer, dimensões teleológicas centrais, presentes tanto na natureza, como na pólis.

Em primeiro lugar, tais categorias pertencem, segundo Aristóteles, à natureza em seu todo, pois dão forma, constituem e possibilitam os nexos causais entre os seres, como também, sua existência e reprodução. Em Política, [I, 1254 a] expõe-se a abrangência destes conceitos, quando se afirma que:

31. G. LUKÁCS, Ontologia del ser social: El Trabajo, p. 69. 
Comandar e obedecer fazem parte das coisas não somente inevitáveis, mas ainda úteis; certos seres, imediatamente desde seu nascimento, encontram-se destinados alguns a obedecer, outros a comandar. Existem, então, justamente formas de comando e de obediência; mas a melhor autoridade sempre é aquela que se exerce sobre os melhores: por exemplo, sobre um homem mais que sobre um animal; pois, o que os melhores realizam é o melhor da obra. Em toda parte onde um comanda e o outro obedece, existe uma obra comum. Com efeito, em todo conjunto composto de muitas partes, mas formando uma entidade comum - quer essas partes sejam contínuas ou separadas - manifestamse sempre governante e governado. E isso é encontrado nos seres animados em virtude da ordem de toda a natureza; pois mesmo nos seres sem vida, existe uma sorte de predominância, expressa na harmonia. $^{32}$

O que se depreende de antemão é o caráter universal, como pertença da natureza, dos atributos de comandar e obedecer. Em verdade, tais qualidades se mostram inatas aos entes, como atributos existenciais. Em outros termos, a natureza convive sob a tutela do princípio bipolar, de domínio e subsunção de uma parte sobre a outra. Então, a natureza é entendida como realidade de contrastes, em que a unidade e a ordem se põem pela imposição e afirmação do princípio dominante sobre o dominado. Condições para dominar, condições para obedecer. De modo diverso, a hierarquia é condição sine qua non de existência do cosmo, de ordenação e equilíbrio do mesmo. Princípio que expõe e afirma a lógica estrutural da natureza, de seus atributos e qualidades, desde a tensão que articula e promove a mais bela harmonia, a mais bela nota, até as relações entre senhor e escravo da pólis desenvolvida. Em Política, I, [1254 a] Aristóteles reitera o argumento, pois todo ser vivo é composto de corpo e alma, o que pressupõe o domínio da alma sobre o corpo, isto é: "a alma comanda o corpo com a autoridade do senhor e o intelecto comanda os apetites com a autoridade do homem de Estado ou de um rei". ${ }^{33}$ O que vemos, uma vez mais, é a forma teleológica do comportamento natural, da hierarquia entre as partes, das funções estabelecidas e, portanto, da regulação e ordem da physis. O que estas preocupações revelam é o domínio de uma parte sobre a outra como algo salutar e desejável, pois tal situação permite a cada ente desenvolver suas funções na direção de sua plenitude, de suas

32. ARISTOTE, Politique, livre I, p. 18.

33. Ibid., p. 19. 
finalidades. O que se afigura, com nitidez, é uma lógica de ordenação da natureza que permite sua reprodução no interior de limites harmônicos, relativamente precisos e reconhecíveis pelos homens. Em outros termos, cumprir a função significa existir e reproduzir-se, enquanto tal, no interior de uma realidade estabelecida e, nesse sentido, configurada dentro de padrões aceitáveis, isto é, da auto-regulação da natureza que impõe a medida entre as partes assegurando sua reprodução como um todo.

Por tudo isso, a dimensão teleológica da physis, sua funcionalidade e orgânica constituem a própria lógica do limite, pois no exercício de cada função, a natureza articula de modo adequado seu modus operandi impedindo, a desagregação e o rompimento da unidade interna, ou seja: a teleologia como lógica de ser da natureza impede que os entes naturais operem para além de suas funções e possibilidades o que, na prática, significa operar dentro de padrões e limites claros, pois se trata de orgânica que tipifica e revela a ordem da physis. Em outros termos, a teleologia como lógica e ordenação da natureza tipifica não apenas o sentimento ou a compreensão dos homens sobre si mesmos e sua realidade, em momento histórico passado, mas, e isto é preciso ter em mente, as idéias teleológicas são as únicas que viabilizam a vida e a reprodução da comunidade em situações de extrema adstringência material, de poucos recursos e limites de toda a ordem.

Em resumo, a presença de uma teleologia natural permitiu aos homens organizar e ordenar os já escassos recursos e, se cada ser cumpre bem sua função, o desperdício se torna pequeno e o aproveitamento maior. Se, ao contrário, um ente realiza uma função para a qual não está preparado o resultado, como tendência, não será positivo e haverá desperdício, pois não dispôs dos meios adequados à realização de sua função. Tendo em vista esse conjunto caracterizado como um universo de carências, Aristóteles [Política, I, $1256 \mathrm{~b}]$ :

As plantas são feitas para os animais e os animais para o homem: os animais domésticos servem ao seu uso e à alimentação; os animais selvagens, senão todos, pelo menos a maior parte, servem à sua alimentação e a suas outras necessidades, para que ele retire deles seja sua vestimenta, seja diversos instrumentos. Se, então, a natureza não faz nada sem objetivo nem em vão, é preciso admitir que é para o homem que a natureza fez tudo isso. ${ }^{34}$

34. ARISTOTE, Politique, livre I, p.26. 
Do exposto, anteriormente, depreende-se o caráter essencialmente teleológico da natureza, pois suas partes se articulam, co-habitam o universo em relações de mútua dependência. Por outro lado, a natureza aparece como provedora dos bens às necessidades dos homens e só existe nesta relação, isto é: a natureza existe para suprir as necessidades dos homens, tanto aquelas ligadas à sua reprodução física imediata (alimentação), como também na forma de matéria-prima para a criação de instrumentos. De tal forma que à natureza é atribuída a dimensão de celeiro cuja existência se põe a partir de uma co-relação com os homens e suas necessidades. Fica evidente, portanto, a pouca capacidade humana em transformar a physis, na medida em que é atribuída à natureza o papel de proporcionar aos homens as suas condições de vida pois, num patamar de agudas insuficiências das forças produtivas, a comunidade limita-se ao que a physis pode oferecer. Páginas à frente, Aristóteles reitera seu raciocínio: “do mesmo modo como a arte política não produz os homens, mas os recebe da natureza e deles se serve, assim a natureza deve fornecer como fontes de subsistência a terra, o mar ou qualquer outra coisa”. ${ }^{35}$ Ou ainda, “a tarefa da natureza, com efeito, é aquela de fornecer a alimentação ao ser que acaba de nascer; todo ser retira sua primeira alimentação do resíduo da matéria de onde ele nasceu”. ${ }^{36}$ Aparece, uma vez mais, o desenho límpido de uma physis cuja função consiste em prover suas criaturas desde o nascimento.

\section{Pólis, teleologia e escravo.}

Em Política, Aristóteles examina as principais dimensões da pólis, isto é, desde a origem das cidades, a organização social, a natureza do escravo e as formas de governo. O esforço do estagirita é notável, pois retrata a preocupação em compreender a cidade como síntese de elementos que se articulam. De fato, a cidade é examinada como síntese de um processo, ou seja, como expressão acabada (mais desenvolvida) face às comunidades pregressas. Comparecem os traços de uma teleologia evolutiva, de um processo de avanço e

\footnotetext{
${ }^{35}$. [Politique, I, 1257 b], Ibid., p.30.
} 36.[Politique, I, 1258 a], Ibid., p. 31. 
modificação das formas pré-políticas de convivência e, sobretudo, seu ápice: a comunidade política, pois em Política, [I, 1252 b],

A comunidade nascida de muitas vilas é a cidade, perfeita, atingindo a partir daí, por assim dizer, o nível da autarquia completa; formando-se para permitir viver, ela existe para permitir viver bem. É por isso que toda cidade existe por natureza, assim como as primeiras comunidades: ela é, com efeito, seu fim, ou a natureza de uma coisa é o seu fim; o que é cada coisa, uma vez acabado seu crescimento, isso é o que nós chamamos a natureza de cada coisa. ${ }^{37}$

A linha de raciocínio de Aristóteles é nítida: a cidade (ou comunidade política) é o resultado ou o fim de um processo que se inicia nas comunidades pré-políticas, quer dizer, a cidade configura e abarca as possibilidades de realização das comunidades precedentes e, como que num universo mais pleno, realiza os objetivos que, em processos anteriores, eram inviáveis ou, no mínimo, acanhados. Então, é posto um forte traço teleológico na constituição das cidades, tendo em vista que a comunidade política visa à plenitude de seu ser, o que na concepção aristotélica significa o bem viver, tornando a comunidade política, um lugar melhor. A cidade é fruto, pois, da sucessão teleológica, seus fins e objetivos implicam excelência, assim

\footnotetext{
Vemos que toda cidade (ou Estado) é um gênero de comunidade e que toda comunidade é constituída em vista de um certo bem (porque todos os homens fazem tudo em vista do que lhes parece um bem), é evidente que todas visam um certo bem e que precisamente o bem soberano entre todos é o fim da comunidade, que é soberana entre todas e inclui todas as outras: é dela que se trata a cidade ou comunidade política. ${ }^{38}$
}

O fim da comunidade política é a comunidade constituída em vista do bem soberano. Disto, resulta necessariamente e, em primeira mão, a dimensão teleológica das formas de convivência entre os homens. Sobre o assunto, Francis Wolf em Aristóteles e a Política, assinala:

${ }^{37}$. ARISTOTE, Politique, livre I, p. 14. 38. [Politique, I, 1252 a], Ibid., p.12. 
Eis por que cada comunidade precedente existia; como vimos, era para responder a certas necessidades que a comunidade anterior não permitia satisfazer: o homem isolado não se pode reproduzir, formando naturalmente uma comunidade com a mulher; os homens naturalmente levados a conceber e os homens naturalmente levados a executar, não podendo prover às suas necessidades cotidianas uns sem os outros, formam uma comunidade; e tudo isto constitui um lar, que cobre todas as necessidades vitais, mas não as outras; de onde a necessidade de um segundo nível, o vilarejo, nascido do lar, que seria a última comunidade se permitisse suprir a todas as necessidades, numa palavra, se fosse autárquico. Ora, não é o caso. A vida, a simples vida com suas necessidades, exige o exercício de outras funções sociais além das do vilarejo, e, portanto, exige uma comunidade de vilarejos/.../A cidade é então autárquica no sentido de ser auto-suficiente: é a menor comunidade que basta para prover a todas as necessidades de seus membros. ${ }^{39}$

E páginas à frente conclui: "Vê-se que os fins das comunidades não políticas não poderiam ser verdadeiros fins. Pois, do casal até o vilarejo, trata-se de meios em vista da vida e eles não bastam a esta vida. Somente o fim da cidade é perfeito” ${ }^{40}$ Fica claro que os fins são distintos, que dentre eles comparece um salto qualitativo, uma vez que a finalidade da comunidade política implica a superação parcial e limitada de dimensões estritamente naturais, da mera reprodução física e biológica dos indivíduos. Entra em cena, portanto, satisfações de ordem social, de como viver bem com os outros e alcançar a felicidade. De modo que, o estagirita faz distinções relevantes entre os fins e, sob forma hierárquica, anuncia que o soberano bem pertence à comunidade política: difícil de ser realizado, mas humanamente o melhor. Comparece, assim, uma lógica na qual a ordem da cidade, sua organização e dinâmica tendem a um fim, a cumprir sua função, a atingir sua plenitude, a encontrar, vale repetir, a felicidade. Uma pólis que manifesta um novo desenho do mundo antigo, isto é, de um homem que começa a compreender sua própria identidade: o de ente comunitário que reconhece os desafios de se viver e de se reproduzir individual e coletivamente em condições extremamente adversas. Nesta contextura, Política comparece como análise original e desafiadora, pois Aristóteles transita não apenas pela história, mas reconhece a interface de problemas que anteriormente nem existiam ou existiam apenas de forma marginal. Ao que parece, a comunidade política oferece um amplo leque de

39. Francis WOLLF, Aristóteles e a Política, p.68-9. 40 . Ibid., p. 73. 
expressões objetivas: em primeiro lugar nas relações dos homens entre si e, por decorrência, dos homens com a natureza.

Nosso exame privilegia, e não poderia ser diferente, as relações matrizadoras entre cidadãos e escravos cujo caráter fundante estrutura e possibilita a produção e reprodução da comunidade política em seu todo, conexão que anima e revela o modus operandi da cidade grega. O que se afigura, antes de mais nada, é a forma como Aristóteles concebe a unidade e importância de tais relações, vale frisar, a teleologia é tomada como categoria existencial, modo de ser que estrutura e permite a reprodução citadina. Então, a realidade é compreendida na exata medida em que se atribui, para cada domínio, uma função específica, de tal modo que as relações são relações de reciprocidade, de necessidade entre o todo e as partes. Fórmula antiga a indicar que nada existe por acaso e que, portanto, sua existência pressupõe uma razão de ser. Não há, conclui-se, espaço para o acaso e a tudo deve ser atribuído um sentido. Marca distintiva dos primeiros livros de Política que relatam o nascimento da pólis, sua finalidade, orgânica e contrastes. No entanto, como referido em nossa Introdução, as ações humanas escapam a este determinismo, pois o acaso e a contingência constituem a própria natureza e lógica dos atos humanos ${ }^{41}$.

Vale repetir, [Política, I, 1252 b] ${ }^{42}$, que Aristóteles esclarece que a cidade política existe para constituir uma vida melhor no momento em que alcança a tão almejada autarquia, ou seja, a vida in communitas é entendida como estágio final que se inicia com as famílias, com as tribos e os povoados, cujo objetivo necessário e progressivo é o bem viver ou como havia anunciado antes na $E N$, o bem humano. A comunidade, como os indivíduos que vivem na cidade são entendidos como elos cujas finalidades são cumpridas por natureza. Assim, o estagirita passa à análise concreta da orgânica que move e é movente nas cidades-estados, ou seja, do enlace decisivo entre senhor, escravo e propriedade privada.

Ao situar a importância da família na vida in communitas, o estagirita argumenta que competia ao chefe de família adquirir os recursos necessários ao sustento e reprodução dos clãs, assim, são examinados os meios mais adequados a permitir tais objetivos: a propriedade, a riqueza e o escravo. Ao chefe de família cabia prover o sustento do oikos,

41. Cf. a Introdução deste trabalho.

42. Cf. ARISTOTE, Politique, livre I, p.14. 
criar as condições para que o clã pudesse se reproduzir não apenas na direção de sua descendência, mas também como figura particular a influenciar os destinos da pólis, ou seja, como elo que permitisse a seus membros a participação na ordem pública da cidade: das assembléias, das magistraturas, da vida militar. ${ }^{43}$ Note-se não estavam em jogo apenas as condições naturais da mera reprodução dos indivíduos, mas nas condições da comunidade política, o chefe de família representava as possibilidades de ascensão e de reprodução política de seu membros. De fato, Aristóteles na $C A$, assinala esta possibilidade em relação a Címon, adversário de Péricles:

Címon, dono de uma fortuna principesca, antes de mais nada desempenhava magnificamente as liturgias públicas, e ainda provia sustento a inúmeros membros de seu demos. Justamente qualquer um dos Laquíadas que assim o desejasse podia diariamente obter provisões suficientes com ele, e também todas as suas terras não tinham cercas, de modo que quem o quisesse podia aproveitar-se dos frutos. $^{44}$

A generosidade de Címon se assentava, provavelmente, sobre interesses práticos e imediatos. Com este gesto o chefe do demos conseguia, muito provavelmente, angariar apoio político às suas pretensões, tais como a participação em assembléias e no governo da cidade. Por outro lado, comparece a idéia grega de que a propriedade (e por extensão a riqueza) tinha por objetivo a reprodução da comunidade e de seus cidadãos, isto é, a propriedade era concebida como meio de reprodução comunitária, desvinculada dos interesses estritamente privados. Ora, é dada à propriedade um caráter teleológico, na medida em que é instrumento de elevação da condição dos cidadãos.

Retomando Política, [II, 1262 b], Aristóteles discute mais em detalhe a forma de propriedade, bem como seu usufruto. A investigação incide sobre a possibilidade do usufruto comum de seus bens mas, mesmo assim, a forma da propriedade devia ser privada. O filósofo inicia suas considerações do seguinte modo:

A propriedade deve ser comum ou não? Essa matéria pode ser examinada mesmo independentemente da legislação sobre as mulheres e as crianças; eu me explico: a respeito da propriedade, mesmo se

43. [Cf. Politique, I, 1253 a e b], Ibid.,p.16-7.

44. ARISTÓTELES, A Constituição de Atenas, p. 63. 
mulheres e crianças são separadas, como é o caso em toda parte atualmente, é melhor que a propriedade seja comum assim como o uso, quer dizer, que exista posse separada da propriedade da terra, mas postos em comum os frutos para consumo (o que se pratica entre alguns povoados), ou, ao contrário, posse comum e trabalho em comum da terra, mas partilha dos frutos para as necessidades particulares (certos povos bárbaros, digamos, praticam também esse gênero de comunidade), ou enfim comunidade dos fundos de terra e dos frutos. ${ }^{45}$

O estagirita reconhece, em primeiro plano, que a propriedade da terra assume formas diferenciadas quanto à sua posse e usufruto, isto é, dispõe, de início, sobre a possibilidade de que a propriedade e o usufruto sejam comuns. Ou ainda, que a terra seja de propriedade particular e o usufruto comum. Ou, que a terra seja comum e o usufruto privado de acordo com as necessidades. Em suma, é discutida a melhor forma de apropriação da terra e de suas riquezas. Para o estagirita a melhor forma de propriedade era aquela capaz de aliar os benefícios da forma comunal, como também de sua posse privada. Da propriedade comunal, ressalte-se a positividade de seu usufruto comum; por outro lado, da propriedade privada o estagirita esclarece que só aquele que fosse dotado de bens poderia beneficiar ou ajudar o outro. Em termos concretos, o filósofo assenta a boa função da propriedade privada nas boas leis e na boa moral, pois "graças à virtude, o uso da propriedade se regula a partir do provérbio: bons amigos possuem bens em comum". ${ }^{46}$, vale dizer:

em certos Estados, um esboço desse regime /.../ prova que ele não é impossível: em particular, nos Estados bem administrados, tanto existe esse regime, tanto ele poderia existir; cada cidadão, possuindo sua propriedade particular, coloca ao serviço de seus amigos alguns de seus bens e se serve de outros como de bens comuns; assim, em Lacedemônia, as pessoas se servem dos escravos umas das outras, como se eles lhes pertencessem, e fazem o mesmo com os cavalos e cães. /.../ É então preferível, é evidente, que a propriedade seja privada, mas que o seu uso seja comum. ${ }^{47}$

45. ARISTOTE, Politique, livre II, p.58-9.

46. [II, 1263 a], Ibid., p. 60.

47. [II, 1263 a], Ibid., p. 60. 
Os homens sentiam-se obrigados a "socorrer os amigos, os hóspedes ou os companheiros, isso é a coisa mais doce; ora, isso não é possível senão com a propriedade privada". 48

A reflexão assume três princípios conexos: em primeiro lugar temos a opção pela propriedade privada; em segundo lugar, a propriedade existia para beneficiar os cidadãos e, por extensão, os amigos; e, finalmente, a boa moralidade e as boas leis supunham e sustentavam a possibilidade do uso adequado da propriedade privada. Então, a propriedade privada assumia dimensão teleológica, pois existia para suprir as necessidades dos cidadãos e daqueles que, por razões diversas, se encontravam impossibilitados de possuir bens ou riquezas. Havia, portanto, uma visão moral sobre a propriedade no quadro da cultura grega, pois as boas leis e a boa moral, em síntese, o bom cidadão, era capaz de sublimar as inviabilidades ingênitas da propriedade privada própria dessa formação social. Fica claro que, no exercício de suas funções, o chefe de família devia dispor de bens e riquezas na medida certa, o que subentende aquisição adequada e limites compatíveis com o padrão moral asseverado pela comunidade. De fato, o modo como o chefe de família se relacionava com a riqueza ilustra o modo limitado de ser da comunidade, visto que a finalidade da riqueza se inseria na possibilidade de resguardar os bens, o que se constata em [Política, I, 1256 b]:

... bens indispensáveis à vida, úteis à comunidade de uma cidade ou de uma família. Esses bens mesmos parecem constituir a verdadeira riqueza /.../ e a riqueza é apenas a soma dos instrumentos que uma família ou uma cidade possui. ${ }^{49}$

Desse modo, a riqueza encontrava-se em limites bem claros: para se viver bem se necessitava de bens no exato limite do que é indispensável, nem mais, nem menos. Os bens eram necessários para promover o equilíbrio que possibilitasse a reprodução da família e, portanto, da comunidade. De fato, adquirir os bens necessários à vida significava, para Aristóteles, adquirir a verdadeira riqueza, pois a verdadeira riqueza (que é a riqueza mínima e indispensável à reprodução comunitária) permitia a reprodução da cidade em moldes modestos, porém factíveis; opondo-se, deste modo, a uma possível degradação da

${ }^{48}$. [II, 1263 a]. Ibid., p. 60,

49. ARISTOTE, Politique, livre II, p.26. 
medida e, por extensão, da vida in communitas. Ora, em Política, [II 1267 a], é renovado o argumento ao se afirmar que toda e qualquer cidade deve dispor da riqueza moderadamente:

... esta deve bastar para fazer face não apenas às necessidades internas da cidade, mas também aos perigos exteriores. É por isso que ela não deve ser nem muito grande que os Estados vizinhos e mais poderosos a cobicem, enquanto seus possuidores seriam incapazes de repelir os agressores, nem muito pequena que eles não possam sustentar uma guerra mesmo contra inimigos iguais e semelhantes a eles. ${ }^{50}$

Em outras palavras, a riqueza tinha por finalidade natural assegurar as necessidades humanas, porém não a riqueza em qualquer estado ou quantidade - o excesso ou a falta mas a riqueza no interior de limites que permitissem a auto-regulação comunitária, ou seja, o excesso gerava cobiça e ambição dos vizinhos; a falta, por seu turno, a impossibilidade militar de se defender, daí o apelo à riqueza equilibrada, capaz de defender a comunidade sem despertar a cobiça alheia.

Destarte, Aristóteles interpõe um limite moral à riqueza, já que a propriedade deveria ser capaz de possibilitar ao homem uma vida melhor, frise-se, o cidadão deveria possuir o bastante para levar uma vida de virtude e de prodigalidade. Da virtude provinha a moderação; da prodigalidade, a generosidade que permitia assistir os amigos. Assim, ao comentar a posição de Faléas e Platão frente à propriedade, temos:

O essencial aos olhos de alguns é que as relações de propriedade sejam bem reguladas: disto, eles dizem, que nascem todas as sedições. É por isso que Faléas/.../diz que as propriedades fundiárias dos cidadãos devem ser iguais /.../ Platão, ele, escrevendo as Leis, pensava que era preciso deixar a liberdade até um certo ponto, mas não permitir a nenhum cidadão possuir mais do quíntuplo da menor propriedade. ${ }^{51}$

Ao considerar algumas reflexões sobre a propriedade, Aristóteles reconhece a marca da cultura helênica, porque tanto Faléas como Platão buscavam limitar a posse das propriedades: o primeiro a partir do estabelecimento da igualdade das propriedades entre os

\footnotetext{
${ }^{50}$. Ibid., p.72.

${ }^{51}$. [II, 1266 b], Ibid, p.69-70.
} 
cidadãos o que, na prática, significava a arbitragem de um limite na aquisição de bens; em Platão, a propriedade era limitada, pois cada cidadão poderia possuir terras na extensão de até cinco vezes o tamanho da propriedade menor. Linhas à frente, ainda em [Política, II, 1266 b], dispõe em tom conclusivo:

Aqueles que propõem uma tal legislação não devem ainda omitir um ponto que eles de fato omitem, é que, fixando assim o montante da fortuna, eles devem fixar também o número de filhos /.../ No entanto, pode ser que a igualdade de fortuna exista, mas que ela seja fixada ou muito alta, de onde o luxo, ou muito baixa, de onde uma vida sórdida decorram. É então evidente que o legislador não deve se contentar com tornar as fortunas iguais, mas que ele deve visar à média. Eu acrescento que mesmo fixar para todos uma fortuna média não serviria para nada, pois é preciso igualar antes os desejos que as fortunas; ora, é impossível se não se dá uma educação conveniente pelas leis. ${ }^{52}$

Em verdade, Aristóteles considera uma série de problemas em torno da propriedade privada que acaba por reforçar a medida como centro organizador da comunidade. O estagirita reconhece que a população não poderia ultrapassar determinados limites num quadro onde existia a igualdade da propriedade, porque, neste caso, o equilíbrio entre a propriedade e seus cidadãos se romperia, isto é, ocorreria o desequilíbrio da vida in communitas. Aristóteles cita algumas leis que impediam a aquisição ilimitada de terras, bem como sua venalidade ${ }^{53}$. Por isso, a própria legislação tratou de impor limites tanto à compra como à venda da propriedade fundiária. Isto, por um lado, impediu (até certo ponto) a concentração exorbitante da propriedade e, por outro, o pauperismo de diversas famílias que se viram impedidas de vender seus bens. De modo que, a regulação entre compra e venda mantém, por certo, as perspectivas do equilíbrio comunitário.

Por fim, vale repetir, Aristóteles confere uma medida moral à propriedade nos termos da moderação, da mediania: mesmo no interior da igualdade de bens que evitava os extremos, de nada serviria a posse modesta da propriedade sem a devida educação dos desejos, o que, para o estagirita, se afigura como mais importante do que a posse limitada de bens:

\footnotetext{
52 . ARISTOTE, Politique, livre II, p. 70.

53. Cf. Politique, [II, 1266 b], p. 70.
} 
... além disso, a perversidade dos homens é um vaso sem fundo: contenta-se de início com dois óbolos, depois, uma vez tomado o hábito, tem-se sem cessar necessidade de mais, até ultrapassar toda limitação; a natureza do desejo é ser sem limite e a maioria dos homens vive apenas para satisfazê-lo. ${ }^{54}$

A sua preocupação é, uma vez mais, reveladora dos limites comunais, na medida em que põe em relevo a necessidade de impor limites tanto à propriedade privada, como aos desejos e às ambições dos cidadãos, quer dizer: a boa lei limitava e dava moderação à aquisição da propriedade, a ética educava o cidadão no uso e na aspiração de bens. Assim, os fins da propriedade eram moralmente infinitos, sua posse não, pois no dizer do estagirita, [Política, VII, 1323 b], os "bens exteriores, com efeito, têm um limite como um instrumento qualquer (e tudo que é útil serve a alguma coisa): seu excesso é forçosamente ou nocivo ou sem qualquer utilidade para aqueles que os possuem". ${ }^{55}$

Nossas considerações são reafirmadas ao se reconhecer que deveria haver um limite e, portanto, uma função para o uso de bens exteriores, ou seja, se os bens exteriores se pusessem para além do necessário (para além de suprir uma vida moderada), a sua utilidade se torna nociva e a função se romperia, isto é, em termos teleológicos a riqueza perderia sua finalidade natural, visto adentrar, por assim dizer, um plano antinatural e, portanto, estranho a seus objetivos ingênitos. De fato, havia o uso adequado e não adequado da riqueza. Ao se ultrapassar a medida, o indivíduo e a comunidade, a virtude e a justiça tornavam-se inoperantes, a medida se desequilibrava, a função se perdia e a riqueza acabava por se contrapor à comunidade. Saliente-se que são postos dois modos de aquisição de riquezas: um pertencente à economia doméstica, ao oikos, cujo objetivo era prover moderadamente a família e auxiliar em sua reprodução; o outro, à crematística cujo objetivo era a aquisição ilimitada de bens, de riquezas e de dinheiro. Dessa forma, não apenas o bom uso da riqueza é examinado por Aristóteles, mas também a forma de sua aquisição. De fato, temos a medida, o limite, o razoável no que tange à aquisição de riquezas, pois a boa arte de sua aquisição, o bom uso desta e a reta conduta moral interferiam significativamente, segundo Aristóteles, nas condições da própria comunidade política. A boa arte de aquisição de riquezas implicava moderação, educação dos desejos e a perspectiva de uma vida em

\footnotetext{
${ }^{54}$. [II, 1267 a],Ibid., p. 72.

55 . ARISTOTE, Politique, livre VII, p. 60.
} 
limites. Viver bem significava viver moderadamente, de forma equilibrada, satisfazendo necessidades no justo limite que a comunidade comportava. Ora, Aristóteles se contrapõe energicamente àqueles que buscam na arte de enriquecer um meio, não para viabilizar a vida, mas para satisfazer desejos ilimitados. O filósofo em [Política, I, 1256 b], aponta:

... uma outra forma de aquisição e que é denominada particularmente, - e ela merece este nome - de crematística e, por sua causa, não há, parece, nenhum limite para a riqueza e para a propriedade; muitos acreditam que ela é idêntica àquela que acabamos de falar por conta de sua afinidade; de fato ela não é nem idêntica, nem parecida com a precedente. Uma é natural e a outra não o é, mas o resultado, antes de tudo, depende de um tipo de experiência e de técnica. ${ }^{56}$

O que torna a última citação acima expressiva é o fato de que Aristóteles não apenas distingue dois modos de aquisição da riqueza, mas - e isto é decisivo - determina o caráter natural e antinatural de ambas, quer dizer: existe a boa e a má função. A boa função exercitava e fazia cumprir a teleologia, enquanto que a má função, pelo contrário, gerava desequilíbrios para o cumprimento adequado de suas finalidades. O excesso, assim, de riquezas implicava no exercício de uma função antinatural, o que, na prática, obstaculizava a ordem, a medida e o limite conquanto reguladores in communitas. Tomemos, pois, a afamada passagem de Política, [I, 1256 b], em que Aristóteles aponta a impropriedade do uso antinatural de um bem, ou melhor, seu uso como valor de troca e, portanto, como princípio de enriquecimento, sem limites e imoderadamente:

Comecemos o estudo dessa forma pela consideração seguinte: cada objeto de propriedade tem dois usos, que todos dois pertencem a esse objeto como tal, mas não da mesma maneira: um é próprio do objeto, o outro não é; um calçado, por exemplo, pode ser calçado ou trocado. Eis duas maneiras de utilizar um calçado. Aquele que troca um calçado com outrem que precisa dele, que tem necessidade do dinheiro ou alimento, serve-se do calçado como calçado, mas não segundo seu uso normal, pois o calçado não foi feito para a troca. O mesmo ocorre com todos os objetos de propriedade, pois a troca pode se aplicar a todos; ela encontra sua primeira origem nesse fato natural, que os homens têm mais ou menos o necessário. ${ }^{57}$

\footnotetext{
56. ARISTOTE, op. cit., livre I , p.26-7.

57. ARISTOTE, Politique, livre I, p. 27.
} 
Aristóteles faz uma distinção entre o uso natural dos bens e o não natural. O uso natural identifica-se com a própria função: está na natureza dos próprios bens a sua utilidade. Ora, cumprir bem sua função se insere na possibilidade de que os bens sejam utilizados para suprir necessidades humanas. Do contrário, seu uso é antinatural, pois os bens não existem para a troca em vista do enriquecimento. No comércio, a troca só é natural se sua função for autolimitada, quer dizer, se a troca se inserir nos limites da autosuficiência da comunidade. De fato, a arte da aquisição visa ao valor de uso, à sua utilidade e, portanto, à sua função. Ao pôr em relevo o valor de uso, Aristóteles reenfatiza a idéia de que a riqueza devia cumprir determinados objetivos, determinadas funções, que seja, sua ordem teleológica. A troca, pois, não era algo essencialmente negativo, o que era negativo em contrapartida, era a troca que objetivava a riqueza ilimitada. Aristóteles em [Política, I, 1257 b], desdobra suas considerações ao reconhecer que o comércio é, essencialmente, este modo nocivo de intercâmbio entre os indivíduos.

Procura-se também alguma outra definição da riqueza e da arte da aquisição, e a procuramos com razão. Pois é outra coisa em relação à aquisição e à riqueza naturais. Essa forma concerne à administração da casa; essa arte, o comércio de miudezas: ele produz bens, não em geral, mas somente pela troca de bens, e ele passa por ter a moeda como objeto, pois a moeda é o princípio e o termo da troca. É verdade também que a riqueza, vindo dessa forma de arte de aquisição não tenha limite. A arte da medicina não tem limite no que concerne às curas, e as artes em geral não têm limite para a produção de seu fim (pois é precisamente esse fim que elas querem produzir), mas elas não são ilimitadas quanto aos meios para atingi-lo (já que esse fim constitui para todos um limite); o mesmo ocorre, dessa forma, com a arte da aquisição: não existe limite ao seu fim próprio, pois esse fim é justamente a riqueza, tal qual foi definida, e a aquisição de dinheiro. Mas a economia doméstica, que não é esse gênero de aquisição, tem um limite, pois o objeto da economia doméstica não é esse gênero de riqueza. Assim, ao se considerar a questão sob esse ângulo, parece necessário que exista um limite a toda forma de riqueza, mas nós vemos o contrário se produzir nos fatos: todas os homens de negócios crescem indefinidamente sua riqueza em espécies monetárias. ${ }^{58}$

O que está em cheque é a própria finalidade do comércio cujo fim é a riqueza ilimitada, fora da medida. Atividade não natural, pois almeja não mais a auto-subsistência,

\footnotetext{
58. ARISTOTE, Politique, livre I, p. 29.
} 
mas a ganância sem limites. Segundo Aristóteles, o que se perde, insiste-se, é a função natural de toda e qualquer propriedade: somente prover e viabilizar a reprodução da cidade em limites estreitos e modestos, ou seja, a riqueza - que da comunidade se isola - perde seus objetivos naturais, sua função desnatura-se, seus fins se perdem. Por conseguinte, o uso ou a função da propriedade na economia doméstica e na crematística são distintos, assim como os indivíduos que a usam, pois como se lê em outro trecho:

... seus empregos invadem um sobre o outro, porque elas têm o mesmo objeto: para todas as duas, os bens possuídos servem ao mesmo uso, mas não com o mesmo objetivo: uma visa acumular, a outra visa uma outra coisa. Daí vem que certas pessoas vêem na simples acumulação do bem o objeto da administração doméstica e persistem em pensar que se deve conservar intacta ou aumentar indefinidamente sua riqueza em espécie. A causa dessa disposição é a preocupação de viver e não de viver bem; como um tal desejo não tem limite, deseja-se para satisfazê-lo meios eles mesmos sem limite. Aqueles mesmos que aspiram viver bem procuram aquilo que contribua com os prazeres do corpo e como isso parece depender dos bens possuídos, toda sua atividade gira em torno da aquisição de dinheiro. ${ }^{59}$

De fato, ambas as formas de aquisição da riqueza possuem o mesmo objeto: a propriedade e o que as difere é seu uso. Aparece, assim, a contraposição entre uma vida moderada (a virtude e os bens na medida certa), e a uma vida de luxúria na qual apetites e desejos são incontidos.

Por fim, ainda no interior da propriedade, passemos ao exame do escravo: propriedade móvel cujo desempenho e importância iria balizar os caminhos das cidadesestado. Em Política, [I, 1254 a], é estabelecida a natureza do escravo:

um ser que por natureza não se pertence, mas é o homem de outrem, esse ser é por natureza escravo: é o homem de um outro qualquer, sendo homem, é objeto da propriedade; ora um objeto de propriedade é um instrumento ordenado para a ação. ${ }^{60}$

59. [Politique, I, 1257 b], p. 29-30.

60. Ibid., p.18. 
A natureza do escravo se revelava enquanto instrumento de ação, alienado de si mesmo. Portanto, o escravo continha a dimensão da animalidade, por ser posto na relação de dependência para com o seu senhor, isto é, o senhor comandava, orientava e exercitava suas funções, mobilizando suas forças na direção e realização de suas tarefas. De modo que o escravo era subjugado duas vezes: em primeiro lugar, pela natureza que lhe impunha tal condição; em segundo lugar, pelo senhor que lhe impunha objetivos cujos fins deveria necessariamente cumprir. Sobre o assunto, em [Política, I, 1254 a], destaque-se:

É então possível, nós dizemos, observar primeiramente em todo vivente a autoridade de um mestre de escravos e aquela de um homem de Estado, pois a alma comanda o corpo com a autoridade de um mestre e o intelecto comanda o apetite com a autoridade de um homem de Estado ou de um rei. Aqui é vantajosa para o corpo a submissão ao intelecto e aquela entre a parte racional e a parte afetiva, enquanto que sua igualdade ou a inversão de suas relações lhe são nocivas. A mesma relação se encontra entre o homem e os outros animais: os animais domesticados têm uma natureza melhor que os animais selvagens, e para todos eles é melhor ser submetido ao homem, pois eles encontram nele sua segurança. Além disso, a relação do macho com a fêmea é por natureza aquela de superior com inferior, de governante com governado; esse princípio se aplica necessariamente, igualmente a todos os homens. Todos os seres, então, que são tão diferentes dos outros, como a alma e o corpo e o homem do animal (tal é o caso de todos aqueles cuja atividade se reduz a usar de seus corpos e que extraem por esse meio o melhor partido de seu ser), são por natureza escravos: é melhor para eles, assim como nos casos mencionados, ser submetidos a esse gênero de autoridade. Assim, aquele é escravo por natureza de poder pertencer a um outro (também lhe pertence de fato) e tem parte na razão apenas na medida onde pode percebê-la, mas não possuí-la em si mesmo /.../ Também a natureza quer marcar ela mesma uma diferença entre os corpos dos homens livres e aqueles dos escravos: uns são fortes para as tarefas necessárias, os outros, direitos de estatura e impróprios a tais atividades, mas aptos à vida política (que se encontra compartilhada entre as ocupações da guerra e àquelas da paz). ${ }^{61}$

O raciocínio acima é claro: a natureza produz homens com capacidades distintas, com corpos e aptidões diferentes para cumprir seu papel na comunidade. Aqui, comparece a força da teleologia, sua importância e orgânica no modus vivendi da cidade grega. Temos, portanto, dois fatos conexos: a pólis encontrava seu fim em proporcionar uma vida melhor, autárquica aos seus cidadãos. Tais condições decorriam, necessariamente, da presença do

61. ARISTOTE, Politique, livre I, p.19-20. 
trabalho escravo, indivíduo naturalmente talhado para encampar determinadas atividades. Sob esse prisma, natureza é provedora, ou seja, cabia a ela prover os homens. Então, não fazia parte do horizonte grego transformar as relações com a natureza e, deste modo, refundar suas perspectivas. Evidencia-se, portanto, os limites ingênitos da vida in communitas: a comunidade política era intrinsecamente subordinada à lógica dos recursos imediatos que a natureza oferecia (comida e animais), assim como da força de trabalho necessária para reproduzir moderadamente a vida citadina. A natureza capacitava os homens: uns para o exercício de um cotidiano rotineiro, de maior ou menor esforço físico e de pouca aptidão mental; outros, no entanto, ao inverso, tinham no intelecto a sua verdadeira razão de ser, a vida política e militar que pressupunha um nível elaborado de capacidades subjetivas. E reforçando as considerações anteriores em [Política, I, 1260 a]:

O homem livre comanda o escravo diferentemente do marido em relação à mulher e o adulto em relação à criança, e, no entanto, as partes da alma existem em todos esses seres, mas elas existem neles diferentemente: o escravo é completamente desprovido da faculdade de deliberar; a mulher, ela a possui, mas sem possibilidade de decisão; e a criança só a possui sob uma forma imperfeita. É preciso admitir que o mesmo ocorre com as virtudes morais: elas devem ser partilhadas por todos, não da mesma maneira, mas apenas na medida em que for necessária a cada um para preencher sua função. Eis porque aquele que comanda deve possuir a virtude perfeita (pois toda função considerada absolutamente exige um mestre da obra e a razão é como o mestre da obra); quanto às outras pessoas, cada uma deve ter apenas na medida em que lhe convenha. ${ }^{62}$

Na mesma linha de argumento, Aristóteles, acrescenta que, [Política, I, 1260 a]: “o escravo é útil para as atividades indispensáveis; é evidente então que ele tem necessidade de pouca virtude, e somente na medida que lhe é necessário para não ser inferior à sua tarefa por mau comportamento ou covardia”, ${ }^{63}$

Assim, a vida grega caracterizava-se pela presença fundamental da teleologia, de seus objetivos e das possibilidades que ela impunha tanto ao modus vivendi da natureza como ao modus vivendi dos homens, com o que se assinala uma vida ordenada em limites, orgânica medial, modus faciendi da própria medida.

\footnotetext{
62. ARISTOTE, Politique, livre I, p. 36.

63 . Ibid., p. 37.
} 
$2^{\mathrm{a}}$ PARTE: LIMITE E SUBJETIVIDADE: POLÍTICA E ÉTICA 


\section{A P Í T U L O I}

\section{POLÍTICA E MEDIANIA: SÓLON, PISÍSTRATO E O GOVERNO DA CLASSE MÉDIA}

\section{Sólon, a política e a mediania.}

As páginas iniciais de $A$ Constituição de Atenas (CA) são conhecidas pela explanação histórica de Aristóteles sobre os pródromos e o desenvolvimento das constituições atenienses. Desde logo, é ressaltado o clima tenso em que viviam pobres e ricos e o papel desempenhado por Sólon nos conflitos fundiários denominados crise agrária do século VI. Aristóteles, nesse contexto, assinala não apenas a importância histórica de Sólon como agente apaziguador das tensões; de pronto, seu interesse recai, e substancialmente, para o modo como Sólon se portou diante dos conflitos, ressaltando a postura equilibrada e eqüidistante com a qual atuava, não favorecendo ricos ou pobres, conquanto o seu objetivo era proteger a comunidade política, sua possibilidade e continuidade, no impedimento de rupturas abruptas, engendrando e consolidando um espaço de dissolução parcial das tensões. Na $C A$, Aristóteles pondera acerca dos momentos históricos que antecederam Sólon:

Com efeito, naquela época o regime era oligárquico em todos os seus demais aspectos, e particularmente os pobres (eles próprios mais as mulheres e os filhos) tornavam-se escravos dos ricos. Dava-se-lhes o nome de péleatas e de hectemórios, pois era por esse arrendamento que eles cultivavam os campos dos ricos (uma minoria detinha todas as terras) e, caso não pagassem os arrendamentos, eles próprios mais seus filhos eram passíveis de cativeiro. Também os empréstimos em geral incidiam sobre as pessoas mesmas até a época de Sólon, o qual veio a ser 
o primeiro líder do povo. Para a maioria, então, a escravização era a mais penosa e mais amarga das disposições do regime ${ }^{1}$.

Assim, o texto assinala a qualidade do regime anterior a Sólon e, simultaneamente, alude à grave crise agrária do século VI, responsável pelo embate entre ricos e pobres, pela escravidão por dívidas, em síntese: pelo desequilíbrio crônico que sempre perpassou a cidade-estado. Mossé observa, pontue-se, que o problema agrário ateniense não é fato isolado e nem mesmo único, pois os problemas mais significativos da comunidade não poderiam estar isolados da terra, entendida como força produtiva, como meio de produção (ao lado dos escravos) a assegurar as possibilidades da vida citadina, pois considera:

O mundo grego da época arcaica e da época clássica é, acima de tudo, um mundo de camponeses; o que explica a importância, no curso da história, dos problemas agrários e dos conflitos provocados pelo problema da propriedade ${ }^{2}$.

Em verdade, o que se põe como novo não é o conflito, pois a Grécia sempre viveu os dilemas próprios da terra, mas a mediação na e pela política encontrada por Sólon em momento adverso e de grande tensão. Ora, o próprio estagirita marca:

... muitos eram escravos de uma minoria, o povo insurgiu-se contra os notáveis. Com o acirramento do conflito, e como se enfrentassem há já longo tempo, elegeram em comum Sólon como mediador e arconte, confiando-lhe o governo. ${ }^{3}$

Em outras palavras, Sólon foi eleito mediador em momento histórico adverso: tempos em que a velha oligarquia ateniense não mais conseguia reproduzir a comunidade como antes e em que onde a própria medida corria o risco de ser rompida. Dessa forma, o estagirita reconhece e personifica, na figura de Sólon e em sua prática, tudo aquilo que havia exposto tanto em Ética Nicomaquéia, como em Política. A caracterização de Sólon encarna, em termos vivos, reais, as idéias de equilíbrio, limite e mediania tão caras ao filósofo. Ao comentar sobre a postura, as reformas de Sólon e suas implicações afirma, na $C A$ :

\footnotetext{
1. ARISTÓTELES, A Constituição de Atenas, p. 17.

2. C. MOSSÉ, El Hombre y la economía. in: El hombre griego, p. 36.

3. ARISTÓTELES, op. cit., p. 21.
} 
Uma vez disposto o regime na forma descrita, passaram a envolvê-lo com queixas contra suas leis, reprovando umas e questionando outras. Mas, como ele não se dispunha nem a alterá-las nem a ser hostilizado por sua presença, fez uma viagem ao Egito a negócios, bem como por curiosidade, afirmando que não estaria de volta antes de dez anos; com efeito, não considerava correto ficarem interpretando suas leis, mas sim que cada um cumprisse o que estava escrito. Ao mesmo tempo sucedeu-lhe também que muitos notáveis divergiram dele por causa do cancelamento das dívidas, como ainda ambas as facções se arrependeram por se verem contrariadas pelo que fora estabelecido. O povo, justamente, acreditava que ele procederia a uma redistribuição de tudo, e os notáveis que, de novo, ele lhes atribuiria a mesma posição ou pouco a alteraria. Mas Sólon contrapôs-se a ambos, e estando em seu alcance tornar-se tirano compondose com o lado por que optasse, preferiu incorrer na hostilidade de ambos mas salvar a pátria e promulgar a melhor legislação ${ }^{4}$.

De fato, ao narrar os acontecimentos históricos, Aristóteles ressalta, de forma deliberada, as inflexões da pessoalidade saloniana diante daqueles que, obviamente, se viram contrariados ou até mesmo pouco atingidos por suas reformas. Em outros termos, Sólon não se curvou diante de ninguém; não se submeteu a nenhum dos dois lados, pois tinha como missão salvar a pátria e promulgar a melhor constituição. E em tal contextura, o que significava não ceder e não pender para nenhum dos lados? Antes de tudo, e estruturalmente, postar-se na mediania, pois só o equilíbrio preserva; significa evitar os excessos, pois estes tendem ao desequilíbrio e à perda da medida. Em verdade, pôr-se na eqüidistância significa fazer emergir a única possibilidade da vida citadina, isto é, a política que se orienta para a mediania, para a imposição de limites, uma vez que sem estes atributos a reprodução societária se vê ameaçada, ou mesmo impossibilitada. Logo, ao se contrapor aos ricos e aos pobres, Sólon viabilizou a única condição de existência para a pólis, a saber: a vida dentro de limites rígidos, pois, vale iterar, a realidade social na pólis era gestada e gerida na fronteira de incertezas ou de extraordinárias dificuldades. Ou ainda, o parco desenvolvimento das forças produtivas implicava domínio restrito do homem sobre a natureza, e, por extensão, sobre si mesmo, o que na prática redundava em adstringências e dificuldades de toda a ordem. Faz-se necessário retomar a argumentação de José Chasin, exposta na Introdução, que aponta o pendor grego ao limite, à regulação e ao controle humano-sociais, sem os quais o tecido social se esgarça, fraciona:

\footnotetext{
4. ARISTÓTELES, A Constituição de Atenas, p. 29-31.
} 
... por seus limites, debilidades e insipiências intrínsecas, a comunidade antiga [o exemplo grego é a melhor iluminura] não é socialmente auto-estável, é incapaz de se sustentar e regular exclusivamente a partir e em função de suas puras e específicas energias sociais. Esta incapacidade ou limite social engendra, a partir de si mesma, em proveito e em vista da estabilidade comunitária, uma dessubstanciação social como força extra-social - uma desnaturação e metamorfose de potência social em força política. Ou seja, esta é uma força social que se entifica pelo desgarramento do tecido societário, dilaceração naturalmente determinada pela impotência deste, e que, enquanto poder, se desenvolve tomando distância /.../ da planta humano-societária que o engendra (mesmo na democracia direta) e a ela se sobrepõe, como condição mesma para o exercício de sua função própria - regular e sustentar a regulação ${ }^{5}$.

O raciocínio é concludente: segundo José Chasin, os limites reais da comunidade grega implicaram o nascimento da política, e esta atua imediatamente como reguladora, como limite a preservar, ordenar e direcionar a vida citadina. Não é isto que faz Sólon quando se opõe a ambas as facções da comunidade? Seu gesto não implica a regulação e busca propiciar a ordem e reprodução societárias? Desdobremos a questão, a partir de outras determinações do estagirita.

Na CA, Aristóteles demarca o fato de que Sólon, podendo constituir-se em tirano, contrapôs-se duramente a tais pretensões ao reconhecer o papel de mediador que a comunidade lhe concedera. O poema atribuído a Sólon e transcrito pelo filósofo ilustra, em tom categórico, esta conduta:

\footnotetext{
Ao povo, pois, dei tanto apreço quanto basta, de sua honra nem tendo retirado nem estirado; os que tinham poder e eram admirados pelas riquezas, também desses cuidei para que nada de indigno passassem. Firmei-me postando um forte escudo contra ambos, e não deixei que nenhum dos dois vencesse injustamente ${ }^{6}$.
}

É nítido, pois, o formato político da conduta de Sólon, sublinhe-se: "firmei-me postando um forte escudo contra ambos, e não deixei que nenhum dos dois vencesse injustamente.” Em primeiro lugar, comparece a idéia de que a vitória de uma das partes era vista como a vitória da injustiça, vale dizer: se um lado se sobrepusesse a outro, quem perderia seria a comunidade, pois a injustiça, rigorosamente, era a vitória da parte

\footnotetext{
5. José CHASIN, O futuro ausente, p. 169-170.

6. ARISTÓTELES, A Constituição de Atenas, p. 31.
} 
sobre o todo, do rico ou do pobre a partir de interesses específicos, privados. Ao que parece, Sólon reconhecia o perigo da unilateralidade de interesses, os malefícios para a comunidade política. Assim, as ações de Sólon se revestem de um caráter muito mais político do que ético, a saber: resguardar a comunidade, seu equilíbrio e unidade; revelando que a ética se põe como instrumento da política. De modo que, para Sólon, os objetivos da política deviam ser encarnados pela justiça, que tinha sua consagração no equilíbrio entre as partes. $\mathrm{O}$ temor da injustiça era o temor da comunidade que perdia as possibilidades de sua existência. Sem o equilíbrio de suas partes, como continuar existindo? Desse modo, Aristóteles assevera:

\footnotetext{
Uma vez senhor da situação, Sólon libertou o povo, tanto no presente quanto para o futuro, ao proibir que se dessem empréstimos incidentes sobre as pessoas, promulgou leis e efetuou o cancelamento das dívidas, tanto privadas quanto públicas, o qual ficou conhecido como sisactia, uma vez que se sacudiram os fardos. A esse respeito, alguns intentam caluniá-lo. Ocorreu, com efeito, que Sólon, já na iminência de realizar a sisactia, mencionou-a a alguns notáveis; então, segundo a versão dos populares, foi envolvido em uma manobra por seus amigos; ou, pelo que dizem os dispostos a difamá-lo, ele também associou-se nela/.../Entretanto, a versão dos populares é mais convincente, pois não é provável que Sólon, tendo sido tão moderado e imbuído de espírito público nos seus demais atos - tanto que podendo governar a cidade como tirano em subjugando um dos dois lados, foi hostilizado por ambos ao preferir a honra e a salvação da cidade à sua própria vantagem - se sujasse em coisas tão pequenas e flagrantes. E que ele tinha tal possibilidade, a situação conturbada o evidencia ${ }^{7}$.
}

O tema é recorrente: Sólon buscou salvar a cidade que vivia uma situação conturbada. Em primeiro plano comparece, uma vez mais, a finalidade da política: a comunidade, a intervenção em momento adverso visando ao resguardo da pólis nascente. Ressalte-se, Aristóteles insiste que Sólon poderia alçar-se à figura de tirano, oprimindo um dos lados, opondo-se abertamente a um dos dois estamentos em conflito; mas, ao contrário, impôs como medida a própria comunidade, não por uma questão ética, essencialmente pela percepção de que só o equilíbrio da cidade é capaz de mediar os estamentos em tensão. Nesse sentido e atribuindo aos ricos a causa principal das tensões sociais, Sólon os adverte:

\footnotetext{
${ }^{7}$.ARISTÓTELES, A Constituição de Atenas, p. 23-5.
} 


\begin{abstract}
Vós, que de muitos bens à saciedade chegastes,
Tranqüilizai no peito o violento coração

e moderai o espírito orgulhoso, pois, nem nós

obedeceremos, nem para vós tudo sairá a contento ${ }^{8}$.
\end{abstract}

A primazia do político incidia sobre a centralidade da comunidade. Sólon pretendia, através de suas reformas - por meios políticos, equilibrar a ganância daqueles que não possuíam limites. O que estava em jogo não era, pois, como à primeira vista poderia parecer, a educação ética dos indivíduos; em verdade, e isto se deve assinalar, a preocupação ética era imediatamente política: limitar a ganância dos indivíduos era o único modo de preservar e dar continuidade a uma formação social que não podia atender às necessidades sociais para além de restritos e adstringidos limites empiricamente verificáveis, amplamente discutidos na Introdução e Parte I deste trabalho. O que se põe, portanto, é o fato de que a postura eqüidistante do arconte ateniense não derivava da generosidade daqueles que se impunham uma justa medida ética; antes, e ao revés, a justa medida ética se realizava como imposição da forma apoucada da cidade-estado. Orgânica que, na prática, imputava ao indivíduo a necessidade de uma vida moderada, restrita àquilo que a pólis podia lhe oferecer. Daí, a advertência saloniana em relação à ganância dos ricos e seu apelo à moderação. Para que a comunidade possa seguir existindo, a política, então, enforma a cidade-estado; a ética, o indivíduo. José Chasin salienta, vale reiterar, que insuficiência e limite implicam força política:

\footnotetext{
Uma comunidade, enquanto condição de possibilidade da exercitação vital dos indivíduos, que seja restrita, parca e estreita no potencial que subscreve a todos que a integram, por isso mesmo rigorosamente referenciada ao metro como idealidade máxima, o que redunda em horizontes conformistas, estanques e estrangulados de convivência e interatividade, não contém, nem poderia conter, puras e exclusivas forças ou energias inerentes à sociabilidade propriamente dita para ordenar e manter, sem mais, a organização comunitária. Pelos seus próprios limites ou insuficiências necessita de algo "externo", para além dela, ou melhor - uma força extra - que a confirme e complete e com isso a viabilize enquanto aparato dinâmico de sustentação do ordenamento social. Força extra que, obviamente, não tem de onde provir a não ser do próprio tecido comunitário ${ }^{9}$.
}

\footnotetext{
${ }^{8}$. ARISTÓTELES, A Constituição de Atenas, p. 23.

. José CHASIN, O futuro ausente, p. 169.
} 
E a urdidura política é

uma força social que se entifica pelo desgarramento do tecido societário, dilaceração naturalmente determinada pela impotência deste, e que, enquanto poder, se desenvolve tomando distância (variável de acordo com os modos de produção) da planta humano-societária que o engendra (mesmo na democracia direta) e a ela se sobrepõe, como condição mesma para o exercício de sua função própria - regular e sustentar a regulação ${ }^{10}$.

De modo que a referência ao metro é essencialmente política; política como instrumento regulador das deficiências e debilidades de uma formação social incapaz de se autogerir, ou seja, de determinante subsunção à natureza. A política, destarte, é filha das inviabilidades de um modo de vida que necessita da medida para ser e se reproduzir. Em outras palavras, o apelo à moderação, à mediania era modus operandi do mundo grego; a ética era o modus operandi do indivíduo, isto é, era imposição de limites e moderação das vontades e apetites.

Desenhado este quadro determinativo, necessário pontuar que grande parte da tradição ocidental apenas reconhece a face positiva da política, sua dimensão ética, ou seja, a mediania política é vista como revolução (diante dos povos bárbaros) a definir, por inteiro, os influxos da humanidade. José Chasin discorre que desde os gregos o homem identificava

na política e no estado a própria realização do humano e de sua racionalidade. Vertente para a qual estado e liberdade ou universalidade, civilização ou hominização se manifestam em determinações recíprocas, de tal forma que a politicidade é tomada como predicado intrínseco ao ser social e, nessa condição - enquanto atributo eterno da sociabilidade ${ }^{11}$.

Sintetizando, a política era examinada de forma unilateral, na medida em que esta tradição entendeu que a vida mediada pela égide do metro, do equilíbrio e do limite era racionalmente e estruturalmente resolvente. Assim, parte significativa da tradição ocidental entendeu o metro político como derivado do metro ético, o que significa que a prevalência da determinação de que a propensão ao limite, à moderação e a mediania entre os gregos era, essencialmente, uma conquista subjetiva e generosa de um povo intelectualmente distinto. O metro político é tomado apenas como medida positiva a

10. José CHASIN, O futuro ausente, p. 169-170.

11. IDEM, Marx - Estatuto ontológico e resolução metodológica, p. 354. 
preservar as cidades, e não enquanto a única equação possível de formações sociais que necessitam do limite, da mediania, porquanto o desequilíbrio as desagrega. Posto distintamente, a medida é tida como aquisição cultural, como conquista de um povo cuja cultura, fundante, extrapola seu espaço e tempo. Knauss, em seu livro sobre a pólis, em uma das muitas passagens expressivas, confirma a formação e importância da medida a partir de condições essencialmente culturais, dizendo que embora a

\begin{abstract}
doutrina délfica mereça o qualitativo de religiosa, sua finalidade não é uma esperança transcendente mas que, autenticamente grega, está dirigida à existência neste mundo. O homem deve chegar a ser homem no pleno sentido da palavra. E como os homens estão necessitados da convivência, é necessário despertar neles o sentido da medida e da eqüidade. O que em Hesíodo aparece, todavia, como uma exigência imprecisa, apoiada em um remoto mandamento de Zeus, se implanta aqui diretamente no homem, em seu conhecimento de si, no conhecimento de que a luta de todos contra todos só pode conduzir ao aniquilamento. A idéia do Direito se converte no fundamento da ordem política. Começa a época dos grandes legisladores/.../Os nomes destes legisladores foram mencionados, todavia, em tempos posteriores com máximo respeito; nomes como o de Corondas, Zaleucos ou Sólon ${ }^{12}$.
\end{abstract}

Teçamos algumas considerações. Knauss adverte que a própria idéia de medida ou eqüidade é pré-política existindo, sob forma difusa, já em Hesíodo. Para o autor, a medida é essencialmente pedagógica, refletindo os ideais da paidéia grega: a catarse de levar os indivíduos à autoconsciência de seus limites, de suas forças e fraquezas, a imposição de limites que impede a luta de todos contra todos. Logo, a medida assume feição jurídica: nasce o Direito cujo objetivo visa assegurar a ordem política, a comunidade nascente. Em outros termos, o autor reforça a idéia de medida como imposição de limites, mas apenas positivamente, não enquanto resultado de adstringências sociais. Ora, Knauss sublinha a importância de Sólon na condição de medida viva, de metro a impor a justiça política a partir de condições subjetivas, ou melhor, a partir da ética que limita os indivíduos; não, como sustentamos, em função da realidade limitada que enforma as possibilidades dos indivíduos. Desse modo, e desdobrando o problema, Sólon representa a

corporificação da medida e da justiça no campo político/.../Nele se combinam a nobreza do sangue e a nobreza das idéias, capacitando-o para reconhecer um caminho que permitiu escapar das lutas sem sentido e conduzir a uma nova ordem plena de sentido; a uma ordem que só pode

12. Bernhard KNAUSS, La Polis-individuo e estado na Grécia antigua, p.111. 
obter-se sobre a base do 'conhece a ti mesmo', pelo conhecimento da medida, a que todo o homem deve submeter-se se quiser criar algo duradouro/.../Sua finalidade não era dominar um partido com a ajuda de outro, mas buscar o equilíbrio entre todos, que é a única forma de estabelecer a possibilidade de uma vida segura ${ }^{13}$.

Sem dúvida, Knauss toma arrimo nas argumentações aristotélicas presentes na $C A$, principalmente aquelas que exaltam a figura de Sólon enquanto político da reta medida. Claro se faz, pois, que a medida se torna instrumento a assegurar as possibilidades de uma vida segura, porque sua função não é apenas criar algo duradouro. Porém, para que isso se efetive, é necessário buscar o equilíbrio entre todos. Palavras contundentes que reforçam o caminho traçado por nossa pesquisa, mas que, ao inverso de nossas proposituras, não entrevêem que o ideal grego da medida era fruto das qualidades mais débeis da cidade-estado, e não, como afirma Knauss, dos mais ilustres espíritos de uma época. De fato, Knauss argumenta com precisão ao reconhecer que a medida possibilitava uma vida segura e duradoura, no interior da comunidade política. Seu engano reside em acentuar a unilateralidade do componente ético da medida, a saber: seu argumento é mediado e sustentado a partir do reconhecimento das melhores virtudes solonianas, o que significa conferir autonomia e independência às mesmas. Não comparece, portanto, o vínculo intrínseco e necessário entre a medida, a subjetividade e a realidade sócio-histórica que lhe dá forma. Escapam a Knauss os vínculos entre a realidade histórica e as formas pelas quais a subjetividade dela se apropria criativamente nos mais diversos e contraditórios níveis e matizes. Assim, o conhece a ti mesmo aparece como filho pródigo de uma dimensão cultural elevada, da sábia cultura helênica: se o é, é na exata medida em que esta cultura notável se enraíza no solo da medida, solo fundante do mundo grego.

As mesmas observações cabem com relação a Paul Cloché, autor de $L a$ Démocratie Athénienne. Cloché destaca a importância do arconte ateniense como precursor de um conjunto de reformas, ou seja, é destacada de forma abstrata a figura do homem político, do mediador:

É no início do século VI que, pela primeira vez, o conjunto do povo ateniense se vê admitido, numa certa medida, na direção dos negócios públicos; a partir dessa época, ele obterá novamente

\footnotetext{
13. Bernhard KNAUSS, La Polis - individuo e estado na Grécia antigua, p.112.
} 
poderes, a intervalos mais ou menos estendidos, mas sem que a democracia tenha sido jamais plenamente realizada ${ }^{14}$.

Cloché assinala, a propensão de Sólon pela medida, pois pela primeira vez o povo ateniense comparecia como coadjuvante dos afazeres políticos, ou seja, Sólon permitiu que se iniciasse um processo no qual os estamentos da comunidade política se poriam num nível de menor desigualdade política, de menor tensão e, portanto, de maior equilíbrio. Desse modo, Cloché destaca o caráter moderado e probo do arconte, pois ao abolir

as dívidas e restituindo aos oprimidos sua liberdade e suas terras, lesou evidentemente os interesses de um punhado de cidadãos 'saciados do bem' e 'com as almas infladas de orgulho', ele não ia até ceder aos apetites das massas, que sua reforma tinha por objetivo liberar, mas não enriquecer/.../radicalmente hostil a todo excesso, ele resistiu da melhor forma às paixões dos 'dois partidos', privando-os assim, um e outro, de uma 'iníqua vitória', para a alegria da Ática, em que o triunfo de um dos dois campos teria coberto de cadáveres. Em suma, ele obrigou os ricos a vomitarem sem fazer concessões desmesuradas ao povo, que, dizia ele, não devia ser mantido 'nem tão solto, nem muito serrado' /.../ Essa moderação consciente, esse partido tomado com equilíbrio entre as soluções extremas distinguem a reforma política de Sólon ${ }^{15}$.

O referido autor assume o espírito da tradição ocidental ao analisar as reformas de Sólon a partir de condicionantes essencialmente éticos, suas palavras revelam o modo e o comportamento de Sólon - sua probidade e disposição de ânimo para fazer valer a medida. É como se Sólon optasse pela medida a partir, e exclusivamente, de sua generosidade como cidadão, das virtudes do bom cidadão.

Nessa exposição, é preciso ainda citar Bruno Snell, helenista alemão e autor de $A$ cultura grega e as origens do pensamento europeu. Divergindo, em parte, dos demais autores, encontra no conceito de medida um caráter nitidamente político e não apenas ético. Ao reconhecer a importância de Sólon, no plano político, afirma:

Sólon toma posição contra a injustiça não porque tenha sido pessoalmente ofendido nem por ressentimento diante de uma injustiça sofrida. Não defende interesses pessoais em nome do direito, mas defende a ordem e o equilíbrio no Estado. Não é a fraqueza nem o ressentimento que o incitam a buscar um valor de caráter universal no qual encontra apoio/.../pelo contrário, o que o move é a idéia instintiva de que cada um deve ter o que lhe compete e um vivo senso da

14. Paul CLOCHÉ, La démocratie athénienne, p.1.

15. Ibid., p.2. 
dignidade e do valor do direito/.../Sólon praticou o gesto surpreendente de renunciar à tirania que já estava em suas mãos. E foi acusado de estultice e de ignávia por não ter aceitado a 'coisa nobre' (assim se definia ingenuamente o poder) que um deus lhe havia dado. Sólon defende-se num poema que chegou em parte até nós: 'A pátria respeitei, e o poder e a tirania eu não quis, e disso não me envergonho embora me lancem em rosto de assim ter maculado minha glória. Com a ajuda dos deuses cumpri minha promessa; não desejo valer-me da violência da tirania ${ }^{16}$.

Snell salienta a atitude do arconte na argumentação que mostra a busca da prevalência da comunidade sobre o indivíduo. Em termos concretos, Sólon pretendia reequilibrar uma situação tensa, esgarçada e de futuro incerto. E, ao tomar posição pela comunidade, as reformas de Sólon atestam, como já configurado, a condição mesma da política, que seja a de regular e de reproduzir as formações sociais helênicas a partir de sua única possibilidade: a comunidade como força produtiva, pois, isoladamente, o indivíduo nada pode. O que se revela, portanto, não é uma inclinação ética pela justiça, movida pelo bom senso moral de Sólon; mas, ao inverso, a opção de Sólon pelo equilíbrio da comunidade era uma questão prática, objetiva, uma vez que disto dependia a sobrevivência da comunidade, o acerto entre suas partes na direção da mediania. A atitude de Sólon, assim, na recusa da tirania, possui muito menos valor moral do que a lucidez em compreender que sua eventual assunção, naquele momento, geraria ainda mais desequilíbrios no tecido social. Em suma, Snell percebe a medida como manifestação do direito, mas não percebe o direito como manifestação das insuficiências da cidade-estado nascente. Nesse sentido, Snell aproxima a esfera política da lógica da realidade, embora não compreenda que o tecido jurídico se radique mediatamente, como a política, em solo humano-social, a partir de suas debilidades e inconsistências.

\section{O tirano e a política : entre a força e a lei.}

Dando curso à investigação da política como instrumento a conter os indivíduos e a própria comunidade em limites factíveis que permitam sua auto-reprodução, torna-se imprescindível considerar o papel mediador exercido pelas tiranias arcaicas na instauração e nascimento das cidades-estado.

\footnotetext{
${ }^{16}$. Bruno SNELL, A cultura grega e as origens do pensamento europeu, p. 182-3.
} 
A tirania faz sua aparição no mundo grego por volta do século VII a.C. Apesar da pouca documentação de que se dispõe, é fato que a tirania comparece como regime político influente a despontar a partir das cidades-estado mais ricas, constituídas de uma nobreza enriquecida e, em alguns casos, dotadas de poderosa armada. Riqueza que se tornou possível pelo advento do ferro, de novas tecnologias agrícolas e pelo incremento do comércio de vasos e cereais ${ }^{17}$. Os poemas de Hesíodo, nesse sentido, ilustram, mesmo que em termos imprecisos, o fosso existente à época entre pobres e ricos. Não obstante o desconhecimento concreto dos acontecimentos, atina-se com o fato de que houve um enriquecimento da oligarquia fundiária gerando reações do pequeno camponês, impotente e marginal frente aos destinos das cidades. Para Mossé, o nascimento das tiranias (arcaicas) na região da Jônia, mais especificamente nas cidades de Mileto, Mytilene, Samos e Naxos, não é casual, mas decorrente da situação próspera em que viviam: com diferenças substantivas de cidade para cidade, a economia fundiária do trigo e vinho se aliou, paulatinamente, com o desenvolvimento do artesanato, da construção de navios, contexto no qual emergiu ademais, mesmo que de forma restrita, a moeda como meio de troca ${ }^{18}$. Mossé sintetiza as condições históricas que permitiram o nascimento das tiranias referindo a existência de um profundo desequilíbrio econômico e social entre o demos e a velha aristocracia, ou o aprofundamento progressivo das desigualdades entre os estamentos, gerado por uma economia que necessariamente os clivava, e ao tecido social. ${ }^{19} \mathrm{O}$ que estava desenhado, pois, era a possibilidade de ruptura das condições e mecanismos de produção que permitiam a reprodução da formação social, a ordem e reprodução societárias em níveis minimamente coesos. Efetivamente, as tiranias nascem de desequilíbrios societários em que a medida se esgarça ou até mesmo se rompe. Nas tiranias arcaicas, o papel desempenhado pelo tirano é nítido: impor a medida, recompor o desequilíbrio perdido, viabilizar o não rompimento do tecido social em momento singular do desenvolvimento das cidades, isto é, moderar o fosso existente entre a velha aristocracia e o pequeno camponês, é o télos de sua ação. Desse modo, o tirano viabiliza a formação e desenvolvimento da cidade-estado, do poder político contido não mais na figura ou na estrutura estritamente familiar, fundando assim as condições objetivas à soberania das

\footnotetext{
${ }^{17}$. Cf. MOSSÉ, C. La tyrannie dans la Grèce antique, p.3-4 e GLOTZ, G. História econômica da Grécia, p.71.

${ }^{18}$. Cf. MOSSÉ, op. cit, p. 12-13 e p.21-22.

19. Ibid., p. 88-9 e p. 94-7.
} 
leis, do direito. Em suma, o tirano arcaico comparece como mediador e político a impor limites à comunidade, notadamente aos estamentos em conflito.

Quanto ao papel das tiranias da época clássica, foi menos político e mais violento. Elas nasceram num momento histórico cuja rivalidade e guerras entre as cidades e/ou impérios era condição que se reitera. Significa, concretamente, que este modo da tirania subjugou, por meio da violência, o inimigo derrotado, criando as condições de domínio e subordinação. Enquanto as tiranias arcaicas (a de Pisístrato é o melhor exemplo) apontavam para o futuro, para o desenvolvimento cultural das cidades e do fortalecimento do demos (abrindo caminho para a democracia), as tiranias clássicas, ao inverso, se consubstanciavam em momento particularmente difícil - da guerra endêmica que frustrou as melhores esperanças dos helenos, situação que necessariamente as insere no terreno da força bélica. As tiranias clássicas ocorreram em época desagregante das relações comunitárias, da luta pela hegemonia política do território grego; a exemplo, aquela que surgiu aos tempos da guerra do Peloponeso, que expôs flagrantemente as inviabilidades da pólis clássica, sua fragmentação política, levando à desordem e ao rompimento das relações comunitárias, da medida. Assim, a ascensão da oligarquia tirânica em 404 a.C, em Atenas, denominada de Os trinta tiranos, emblemática, ocorreu precisamente a partir da derrota ateniense, isto é, em uma Atenas enfraquecida política, econômica e militarmente por quase trinta anos de guerra. De sorte que, na contramão dos tempos arcaicos, o tirano do século IV compareceu e encontrou espaço na e pela grave crise; a tirania clássica sinalizou as mazelas de uma formação social em convulsão, em meio a lutas fratricidas, em suma, marcou uma orgânica desmedida, que necessitava ser reencaminhada, reposta em trilhos medidos, pelos quais marchava o tirano, entendendo costurar, com medida, um tecido social que, se esgarçado, interditaria a comunidade.

Analogamente, e retomando a argumentação anterior, as tiranias arcaicas nasceram por oposição aos excessos dos proprietários da terra (a desmedida). O tirano corporificava a medida, por ser o único capaz de recompor o equilíbrio da cidade, de impor condições mais favoráveis ao camponês secularmente pobre. Tratava-se, uma vez mais, de agir no sentido de preservar a medida, ainda mais em tempos em que a pólis era nascente e o demos ainda acanhado. Aristóteles, em Política,V, [1310 a e b], assinala o nascimento da tirania e a constituição da medida ao afirmar que "O tirano /.../ sai do povo e da massa para protegê-los contra os notáveis, afim de que o povo não 
sofra qualquer agravo de sua parte". ${ }^{20}$ Ora, o tirano é a solução política de tempos pouco políticos: a tirania é a mediação enérgica a restaurar a medida, ou seja, ao impor a medida pela força, o tirano atua a partir de expedientes mais ou menos políticos, cujo objetivo é essencialmente político - a preservação e equilíbrio da pólis. Jaeger, em síntese apropriada, define a tirania como a "transição entre a nobreza e o Estado democrático" $^{21}$. Transição em que o demos, vale repetir, ainda não se afigurava como comunidade, como soberania do nomos. É certo que as tiranias nascem de "Estados incapazes de estabelecer por si próprios uma ordem eficaz e legal, de acordo com a vontade da comunidade ou duma forte maioria"22. Em outras palavras, o quadro histórico nos remete para um período no qual, de parte a parte, era inviável assegurar a ordem da cidade apenas pelo direito, pelas leis, que, cem anos depois, matrizariam as relações entre os indivíduos, regulando suas vontades e passos. Assim, para o tirano, afigura-se a possibilidade de destruir o poder ligado às relações pessoais de consangüinidade, típicas das tradições homéricas. Tempos novos, porquanto se põe o rompimento com formas arcaicas do poder político, contrárias ao demos e centradas nas relações de parentesco, como atestam as palavras de Croix ao referir-se aos governos tiranos:

... já havia desaparecido o domínio da aristocracia fundiária, exceto em alguns lugares, sucedendo-lhe uma sociedade muito mais 'aberta': o poder político não se baseava na linhagem, no sangue azul, mas dependia principalmente da posse de bens (situação que se converteu a partir de então na típica forma da oligarquia grega), e em muitas cidades, como por exemplo Atenas, se estendeu em teoria a todos os cidadãos, convertendo-se em uma democracia ${ }^{23}$.

É este mesmo espírito determinativo que escorre da letra de Jaeger, quando afirma que o "tirano é verdadeiramente um político", pois a este cumpre reordenar as relações entre a aristocracia e o povo, preparando, entre outras coisas, as bases para o ensejo da democracia. O que não poderia ser diverso, é que a própria condição da riqueza se altera: do nicho estritamente familiar e rural, ganha formas mais impessoais, ou menos familiares, constituindo horizontes mais amplos; a riqueza nascida da atividade não fundiária, ou aquela advinda do comércio e de pequenas unidades artesanais. Dessa maneira, esboça-se um mundo de novo talhe, em que a medida é a

20. ARISTOTE, Politique, livre V, p.73-4.

21. W. JAEGER, Paidéia: A formação do homem grego, p. 250.

22. Ibid., p.254.

23. DE STE. CROIX, G.E.M, La lucha de clases en el mundo griego antiguo, p. 329. 
própria condição de sua existência, da pólis nascente, orgânica marcada por constrangimentos e limites históricos, nos quais o exercício da medida é coação efetiva (não escolha), coação que implica desde logo a própria possibilidade da cidade-estado. Nas palavras de Mossé: "a obra do tirano consiste em fazer desaparecer as desigualdades" 24 .

Se, por um lado, o tirano necessariamente impõe a medida, também, em determinadas situações, a ela se sobrepõe: ao impô-la, o tirano necessariamente suplanta a ordem e a soberania do nomos. Contradição específica de um governo que assumiu uma identidade dúbia, a saber, exercer a política se as circunstâncias permitissem ou, em sentido inverso, justapor-se ao nomos caso a realidade o exigisse. Nos gregos, a tirania padeceu dessa dubiedade insuperável. Tomemos, brevemente, a questão.

A idéia de medida, do nomos regulador da comunidade, apareceu para os gregos como inovação, como superação do modo de vida dos bárbaros. A regulação ou não da comunidade pelo nomos foi decisiva para julgar o tipo e a forma de governo. Para Knauss, a revolução e instauração do político consistiu em que "a comunidade grega, independente e zelosa de sua vontade livre, se desprendia, ela mesma, de uma parte de seu poder e o transmitia a outra instância, mas não a uma instância pessoal, mas suprapessoal, à lei". ${ }^{25}$ Knauss, pois, afirma a soberania da lei e a impessoalidade do poder político: se a lei é soberana pouco importa quem exerce o poder, porque deve prevalecer o respeito ao nomos:

... os gregos suportaram a tirania do 'nomos', levados pelo sentimento autêntico de não se submeterem, a partir dele, a uma vontade humana, mas a uma exigência política fundamental; mais ainda, ao sentido do Estado mesmo, expressado no 'nomos' como princípio constitutivo da ordem e do equilíbrio ${ }^{26}$.

O respeito à lei significava respeito ao Estado, e o respeito ao Estado era a possibilidade da soberania da lei, voltada à comunidade, cujo objetivo maior era manter e preservar a ordem e o equilíbrio. Disto, portanto, resultava o temor grego frente à tirania: no exercício da imposição necessária de sua vontade, o tirano não apenas exercia a força, mas, posto este contexto, propendia para além de qualquer medida, da moderação, tendendo ao forjamento de um terreno que se descolava das leis,

\footnotetext{
24. C. MOSSÉ, A Grécia arcaica de Homero a Ésquilo, p. 173.

25. Bernhard KNAUSS, La Polis- individuo e estado na Grécia antigua, p.106.

26. Ibid., p. 118.
} 
sobrepondo-se à própria soberania. Dito diversamente, ao suplantar a soberania do nomos, ao instaurar uma lógica e prática que desvinculavam nomos e indivíduo, o tirano colocava em risco a própria existência do Estado, por conseqüência, a própria comunidade, posto que Estado e comunidade se imbricavam de modo estrutural. Por esse ângulo, a tirania era vista com preocupação e até mesmo com aversão, pois o governo da desmedida podia e implicava, em última análise, no próprio desfibramento do tecido social. Knauss ratifica estas considerações ao indicar a dimensão dúbia e socialmente contraditória do poder ilimitado do tirano, na exata medida em que tal poder se ordena tanto

para o bem, como para o mal. O poder ilimitado do tirano não era, no entanto, o mais perigoso. Muito mais funesto era o fato de que a eliminação da lei, do governo contra o nomos, criava um precedente que poderia ter grandes conseqüências. Se o nomos desaparecesse, não haveria barreira alguma que impedisse o indivíduo ou as massas de atuarem com vistas a si mesmos, em proveito próprio, tratando de impor seus interesses pela força proclamando-se tiranos se a ocasião se apresentasse propícia ${ }^{27}$.

A tirania é um desgoverno da lei, um atentado ela mesma à medida, ao nomos. Por isso, o perigo que o tirano encerra não é apenas de ordem pessoal, circunscrito ao raio individual, pois seu desgoverno não é passível de superação pela mudança de um comportamento ou mesmo por sua substituição. A ação, em desgoverno, uma vez exercida, atinge de pronto toda a orgânica social, pois, se a medida é rompida pela ação tirânica, como realizar ou preservar o equilíbrio, precário, da comunidade? A desordem que se entende tiranicamente corrigir é posta por interesses contrapostos, de difícil conciliação porquanto essencialmente desarmônicos. Nesse sentido, a lei assegura a possibilidade de que tais interesses divergentes sejam, no mínimo, postos num patamar de coexistência. A vida exercida pelo império da força, e não da lei, por seu lado, não pode assegurar à comunidade que a própria força não se volte contra o tirano, e por extensão, contra a cidade-estado, impondo condições imprevistas e inadmissíveis a um Estado que encarna ele mesmo o sentido positivo da vida, ou mais rigorosamente, a condição de reproduzi-la em moldes mais plenos, civilizados. Não obstante, e especificando a argumentação que conforma a contradição imanente que perpassa a ação tirânica, a condição do tirano nos tempos arcaicos é, nas mais da vezes, ambígua: nascido dos embates contra a velha aristocracia fundiária, perpetrara, pelo ato da força,

27. Bernhard KNAUSS, La Polis - individuo e estado na Grécia antigua, p. 149. 
a medida contra a velha aristocracia a favor do pequeno camponês. Seu objetivo, no entanto, era claro: conter, minimamente, o fosso das desigualdades colossais que atentavam contra a orgânica e reprodução da pólis nascente. De tal forma que o tirano faz uso da força, da imoderação, com a finalidade primeira de preservar a comunidade, administrando acima do nomos. Significa que, em determinados momentos, a preservação da cidade-estado exigiu atitudes não políticas (caso das tiranias), mas sua intenção, como já se pontuou, era fundamentalmente política: prover sustentabilidade à orgânica da pólis, pois a comunidade não era ainda uma efetiva comunidade, um demos soberano. Nessas condições, frágil em sua unidade, a tirania comparece como poder a subsumir o nomos em nome da medida, isto é, da comunidade, o tirano, no exercício prático não poderia não agir, no mais das vezes, de forma moderada, prudente, respeitando a medida e a soberania das leis. Ambigüidade de fundo que implicou uma lógica e procedimento opositivo e conflitante: à política se atava, quando necessário, a violência; ora moderador, ora violento, mas sempre a favor da medida, que preservava e regulava as cidades, que preservava e regulava o modus faciendi tirânico. Em suma, no mundo da justa medida preservadora, o tirano é ação que a substantifica e, por esse motivo, o uso da força é movimento moderador, de tal modo que sua objetivação desfaz para conter, impede para reproduzir, não para simplesmente aniquilar ou subjugar; lógica reveladora de que o tirano é estabilizador, pulso enérgico, se necessário, da preservação da medida.

\section{Pisístrato: o tirano moderado}

O caso de Pisístrato é singular. Dentre todos os tiranos é o mais conhecido. De ascendência ateniense, tem a favor de sua própria fama um conjunto rico e amplo de documentos históricos. De Aristóteles a nossos dias, parece haver uma unanimidade acerca do papel positivo de Pisístrato como tirano, dos benefícios de seu governo para Atenas. Numa repercutida passagem da $C A$, Pisístrato é assim caracterizado:

Pisístrato/.../administrava os negócios da cidade com moderação, e antes como cidadão do que como tirano. Em geral, com efeito, era humano, brando e clemente para com os infratores e, em particular, adiantava empréstimos em dinheiro aos que estavam em dificuldades, viabilizando seus trabalhos de modo a se sustentarem com o cultivo da terra ${ }^{28}$.

28. ARISTÓTELES, A Constituição de Atenas, p. 41. 
Aristóteles marca a lógica da conduta de Pisístrato através de dois traços: a moderação na administração da cidade e a concessão de empréstimos que fazia aos pequenos camponeses em dificuldades. Em relação à postura moderada do tirano convém ressaltar o seguinte: assumiu o poder aproximadamente dez anos depois das reformas de Sólon que, não obstante o relativo sucesso, foram impotentes para dirimir o principal foco de tensão à época, a partilha da terra. Ao não ceder às reivindicações do demos ateniense, Sólon apenas postergou os conflitos e dilemas seculares, atenuando sim seus aspectos mais gravosos, mas de forma alguma solucionando-os. Então, as tensões renasceram, os conflitos reemergiram, e a medida, uma vez mais, fragilizou-se. Em um quadro de agudas insuficiências, surgiu a figura de Pisístrato, político mediador, disposto a repor a condição da reprodução da vida, isto é, a medida, e desse modo a assistência para o camponês empobrecido. Ao que parece, Pisístrato se pautou por uma postura equilibrada, muito mais política do que tirânica. Talvez, o que possa explicar tal atitude seja o fato de que o simples uso da força poderia não ser resolutivo, dado o nível de tensão e fissuras vividos pela comunidade. Neste contexto, o uso da força não encontraria arrimo suficiente para se impor a partir de um dos dois lados em litígio. Ademais, Pisístrato assumiu o governo quando Atenas já havia experimentado sua primeira experiência sob a regência do nomos, as reformas de Sólon, que demarcaram em tons suficientemente visíveis o espaço político vivido pelo tirano. De fato, e é isto que importa salientar, Pisístrato portou-se positivamente pela medida sustentada no misto de moderação e violência, mas sua inclinação esteve marcada pela assunção de uma postura e ato predominantemente moderados: ao reconhecer os problemas da cidade, o tirano atuou na direção de repor o equilíbrio, reduzindo a tensão existente entre pobres e ricos, a partir de empréstimos. Pisístrato, com o que se remonta à palavra de Jaeger, foi um verdadeiro político, posta a forma como recompôs as condições da medida para a comunidade.

Outro aspecto relevante do tirano foi seu o papel no desenvolvimento das cidades, voltado para o interior da medida, pois, sob sua liderança, as cidades ganharam prosperidade por uma ação que encontrara no equilíbrio um pilar não secundário. Equilíbrio cuja objetivação encontra, na política, sua via determinante de consubstanciação. Na $C A$, ao se referir especificamente ao governo de Pisístrato, o estagirita afirma: 
Em geral, durante seu governo não atormentou a multidão em nada, antes sempre manteve a paz e velou pela tranqüilidade; por isso mesmo, difundira-se a fama de que a tirania de Pisístrato era como a vida no tempo de Cronos/.../O mais importante de tudo o que foi dito era seu caráter popular e humanitário. Em geral, com efeito, dispunha-se a administrar tudo em conformidade com as leis, sem se conceder nenhuma vantagem/.../Por isso mesmo, conservou-se no poder por muito tempo, e uma vez derrubado novamente o retomava com facilidade. Com efeito, a maioria dos notáveis e dos populares o apoiava, pois ele conciliava uns por meio do convívio, e outros pela assistência a seus interesses privados, estando ainda naturalmente bem disposto para com ambos. $^{29}$

Desse modo, para Aristóteles, a via política poderia ser a única possibilidade ativa e estrutural para o tirano, ou seja, o estagirita firma a preocupação de Pisístrato em governar de acordo com as leis, sem conceder vantagens, visando à paz e à tranqüilidade da comunidade. Efetivamente, outra não foi a intenção de Pisístrato ao articular, harmoniosamente, a convivência entre a velha aristocracia e o demos. Finley assim descreve os tempos de Pisístrato:

\begin{abstract}
Na verdade, sendo um tirano, conseguiu realizar aquilo que Sólon não fizera, e foi durante o seu reinado que os camponeses alcançaram finalmente uma posição segura e independente no território, com a ajuda financeira quando requerida, que a luta civil se atenuou e que o monopólio político das famílias aristocráticas foi eliminado de uma vez por todas. Os nobres continuaram a manter os cargos civis e militares mais importantes - como também o fizeram pelo século seguinte sob a democracia - mas as circunstâncias e a psicologia sofreram uma alteração radical. Eram agora, cada vez mais, servidores do Estado, instrumentos do direito, e não arbitrários detentores do poder; da mesma maneira que as pessoas comuns eram agora homens genuinamente livres, não mais ameaçados pela escravidão por dívidas ou por uma justiça totalmente controlada por uma classe. As duas facções estavam muito longe de ser iguais, mas, pelo menos, as diferenças entre elas tinham sido reduzidas a uma escala e proporção manejáveis ${ }^{30}$.
\end{abstract}

De suas palavras imediatamente se infere a forma como Pisístrato tratou dos negócios da pólis: com equilíbrio e moderação ao estabelecer a medida para todos a partir do direito. Foi assim que Pisístrato criou as condições para que a medida fosse reposta, permitindo, assim, as condições de reprodução da comunidade sob novos parâmetros - com menor tensão e desigualdade entre as partes envolvidas. Assegurou os cargos civis e militares à nobreza, e, simultaneamente, colocou o pequeno camponês em

29. ARISTÓTELES, A Constituição de Atenas,p. 41-3.

30. MINLEY,Os gregos antigos, p. 39. 
patamares menos perversos, um pouco mais dignos e seguros. Enfim, Pisístrato repôs os limites mínimos da reprodução societária através da regulação política, o que significa dizer que coube à política impor a reta medida às partes envolvidas, assegurando o equilíbrio e desenvolvimento da cidade-estado em parâmetros mais generosos e de futuro mais consistente. Não é por razão menor que Aristóteles reconhece em Pisístrato o político competente a mediar os conflitos e a encontrar, pela política, as soluções cabíveis, isto é, a medida que assegura e permite a ordem e regulação societárias.

A medida sempre se pôs como atributo importante da vida das tiranias, como se entrevê na consideração de Mossé sobre Periandro: "deste poder absoluto, teria posto em prática uma política decididamente antiaristocrática, não só condenando à morte ou ao exílio os seus adversários, mas também impondo a aplicação de medidas destinadas a limitar o luxo dos poderosos" ${ }^{31}$. Do mesmo modo que Pisístrato, Periandro age no sentido de atualizar a medida para a comunidade, ao coibir o luxo dos poderosos o tirano de Corinto impede o rompimento da medida, entendendo assim preservar as possibilidades de reprodução da cidade. Ao contrário de Pisístrato, Periandro exerceu a medida muito mais pela força, pela violência, do que pela política. Tratava-se de exercer e preservar a medida por meios não políticos, ou seja, estabelecer a medida significa ordenar e reproduzir uma formação que, na ausência do metro, desordena-se, incapacitando-se. Com essas palavras, Mossé assinala os propósitos da tirania em Corinto:

\footnotetext{
Nascida da crise por que a sociedade aristocrática vem a passar, ela contribui, pelo recurso à violência e usurpação do poder, para a destruição dos privilégios desta aristocracia, e mediante a penhora lançada sobre as riquezas da cidade-estado, de que o dízimo de Cípselo dá claro testemunho, para remediar de certa maneira as desigualdades sociais ${ }^{32}$.
}

Ora, assinala que Periandro (e seu pai, Cípselo) tomaram o poder com propósitos claros: confrontar e impor limites aos privilégios de uma aristocracia que, por si mesma, é predadora, esgarçando o tecido social, confronto e imposição que diminui a distância e a tensão existentes entre este estamento e o povo. Não se tratava, pois, de uma postura ética, negadora das condições desfavoráveis de inteiras porções sociais, que conduzia a ação tirana; ao contrário, o cuidado com o demos era, primariamente, a condição de possibilidade da manutenção da vida in communitas, sem a qual a própria aristocracia

31. c. MOSSÉ, A Grécia arcaica de Homero a Ésquilo, p. 173.

32. Ibid., p. 175. 
definharia. De modo que é imanente ao poder da tirania a exercitação da medida, seja pela violência, seja por meios políticos, com o que se diminui o desequilíbrio das cidades, repondo medida e ordem. Intervenção tirânica que, na prática, jamais redundou em alteração nas formas ou distribuição da propriedade fundiária. O tirano buscou "restabelecer uma determinada igualdade entre os membros da comunidade sem que, para tanto, houvesse necessidade de atentar contra a propriedade, de proceder a uma partilha igualitária da terra". ${ }^{33}$ Em outros termos, ao tentar minimizar as desigualdades, os tiranos criaram taxas ou tributos que, no máximo, permitiam assegurar ao demos condições mínimas de reprodução, seguridade, então, forjada no interior de uma situação adstringida, minguada. A força e a lei regulavam, e pelo equilíbrio tênue da medida se amparava o camponês, ainda que reposto minimamente, a garantia da reprodução comunal da riqueza, e de seu contrário.

Assim, e em linhas gerais, com que se conclui, as tiranias, incluindo a de Periandro, foram responsáveis pela dissolução de um poder tipicamente familiar, abrindo, nesse sentido, para o fortalecimento do demos e de um poder centrado nas instituições. Fato que revela que "o nascimento e a pertença a um genos, a uma grande família, tinham deixado de constituir critério de acesso às magistraturas" ${ }^{34}$. Também permite afirmar que as tiranias arcaicas tiveram papel marcante, conquanto transitório, no desenvolvimento e afirmação da medida, do poder político e do demos. Em relação à medida, especificamente, os tiranos a constituíram e exerceram-na num momento em que ainda não se havia firmado seu caráter nitidamente político, ou quando mediada pelas instituições, pelo exercício da magistratura sujeito à soberania do direito e à imposição das leis. Não obstante, as tiranias reconheceram que a medida, mesmo que pela força, deveria ser imposta, pois instrumento único a viabilizar as possibilidades da cidade-estado nascente. Reconhecimento, enfim, que demarca uma percepção dos tiranos, maior ou menor, em cada caso, acerca dos problemas ou fraquezas intrínsecas às cidades da época arcaica. Em suma, e que se sublinhe: a tirania criou o locus e as condições que permitiram o nascimento da política, do direito como afirmação da mediania, do equilíbrio em proveito da comunidade.

\footnotetext{
33. C. MOSSÉ, A Grécia arcaica de Homero a Ésquilo, p. 184. 34. Ibid., p. 175.
} 


\section{Política e limite: a constituição}

Em Sólon e Pisístrato, Aristóteles reconhece a importância da medida em termos práticos, como instrumento político a preservar e desenvolver as possibilidades da cidade-estado, isto é, ambos sinalizam a propensão grega pela medida, sua relevância enquanto único caminho a despontar como solução, mesmo que parcial, dos conflitos e tensões sociais nos pródromos do século VI a.C . O estagirita toma arrimo na exemplaridade de personagens e fatos históricos, que, por contraste, forneceram as evidências da correção de seu ideário político. Desdobremos então nossas considerações acerca da teoria política aristotélica a partir de sua matriz capital: a mediania, que enerva e estrutura a base de sua argumentação.

Na CA e em Política, Aristóteles chama a atenção para o fato de Sólon e outros legisladores serem oriundos da classe média: "Sólon era, pelo nascimento e pela reputação, um dos principais, mas pela fortuna e pelos atos, um dos do meio" ${ }^{35}$. Ou nas palavras de Política, IV, [1296 a]:

É preciso ver ainda uma prova disso no fato de que os melhores legisladores foram os cidadãos da classe média: Sólon, como ele o manifesta por sua obra poética. E também Lycurgo, que não era rei, e Charondas e, em suma, a maioria dos outros ${ }^{36}$.

Aristóteles ressalta a importância de que muitos legisladores pertenceram à classe média, de riqueza moderada e atitudes equilibradas. As qualidades distinguidas, sem dúvida, exaltam a mediania, o comportamento medido. A categoria da mediania perpassa não apenas os estudos sobre as melhores constituições, mas também adentra na caracterização dos melhores legisladores: comparece a informar a lógica e o entendimento aristotélico sobre a política, os indivíduos, os governos, etc. De Política, toma-se, para efeito argumentativo, os seguintes temas capitais, postos por Aristóteles: a natureza das constituições e o propósito dos governos retos que seria o bem comum (aqui se põe o contraste face aos governos desvirtuados); em seguida, o exame de sua reflexão sobre os méritos e debilidades dos diversos regimes, com o que se conclui pela superioridade do governo exercido pela classe média, denominado de politéia. Em análise cuidadosa, o autor da Política reconhece os desequilíbrios próprios de cada

\footnotetext{
35. ARISTÓTELES, A Constituição de Atenas, p. 23.

36. IDEM, Politique, livre IV, p. 171.
} 
constituição, reconhecimento que significa a determinação de que a medida fornece os parâmetros para aferir as melhores e as piores qualidades de cada regime.

O livro III de Política tem início com a análise da natureza das constituições, de sua função no seio das cidades. Aristóteles desenvolve uma série de observações, nas quais a constituição é caracterizada sob diversos aspectos: um deles, e fundamental, assinala o papel das mesmas como instrumentos a ordenar a vida citadina, estabelecer sobre o exercício e a ordem das diversas magistraturas, da duração e possibilidade de se assumir, mais de uma vez, determinadas funções. Na elaboração sintética do filósofo, em [Política, III, 1278 a e b], lemos:

Constituição é organização das diversas magistraturas de uma cidade, e especialmente daquela que possui o poder soberano; por toda parte, com efeito, o governo detém a autoridade suprema na cidade e, de fato, a constituição é o governo ${ }^{37}$.

Esboçando, assim, a natureza e função das constituições, Aristóteles volta-se para o modus operandi da política em cada forma constitucional, e, neste movimento, o estagirita reconhece as debilidades e virtudes próprias de cada regime, do que nasce a formulação da melhor das formas, ou teoria-síntese do filósofo, substantificada na constituição mista.

\section{IV.1 Cidadão e soberania: formas particulares da cidadania.}

O livro III de Política nos remete à intrincada discussão acerca da cidadania, de sua extensão e implicações nos diversos regimes políticos. O que está posto são formas particulares de cidadania e de cidadão, que apontam para distinções importantes no trato do exercício político. Aristóteles examina a peculiaridade da atividade política em algumas formas de governo como a aristocracia (e seu desvio, a oligarquia), a democracia e as cinco formas particulares da monarquia. Exame, frise-se, que se desdobra de fato nos livros subseqüentes, notadamente no quarto, quinto e sexto respectivamente.

Nas páginas iniciais do livro III, Aristóteles expõe sua preocupação central: examinar o modus operandi da cidadania em cada regime específico e reconhecer até

\footnotetext{
${ }^{37}$. ARISTOTE, Politique, livre III,p. 64-5.
} 
que ponto o modus operandi de cada constituição afetava a construção da vida citadina. Nesse sentido, existe o entendimento, por parte do estagirita, de que o exercício da atividade política ganhava contornos distintos a partir da inserção maior ou menor de cidadãos no trato da coisa pública. Por outro lado, o exercício da soberania definia, para o pensador grego, a forma particular dos regimes; neste contexto, Aristóteles passa a investigar quem de direito devia exercer o poder político: se os mais pobres, ou os melhores, os mais ricos ou um só indivíduo. E no interior desta problemática, ao examinar os diferentes regimes, o estagirita envereda pelo estudo da melhor forma constitucional, ou, no mínimo, pela aferição do regime mais adequado aos propósitos da política: o bem dos cidadãos. Quanto à pertença da soberania, questão fundamental à ordenação da vida citadina, Aristóteles é claro ao refutar um poder nas mãos dos mais pobres: estes tendiam a se opor aos mais ricos, visando à redistribuição da riqueza, o que projetava, ou ao menos facilitava uma tomada irregular e imprópria dos bens alheios. Em tal contexto, nasce então a pergunta [ Política, III, 1280 b]:

\footnotetext{
Quem deve ser o soberano da cidade? Será evidentemente ou a massa popular ou os ricos ou os homens de valor ou um só homem, o melhor de todos, ou um tirano. Mas cada um desses casos comporta inconvenientes manifestos. O que então? Se os miseráveis, porque eles são os mais numerosos, dividem entre si os bens dos ricos, isso não é uma injustiça? ${ }^{38}$
}

Dessa maneira, a democracia era vista com reservas, pois o comando político por aqueles que pouco ou nada tinham, o exercício do poder político pela massa pobre, tendia a intensificar a ingênita oposição social. Para Aristóteles, a democracia era o governo dos mais pobres no interesse dos mais pobres, não uma ação no interesse da comunidade. Por este contorno, a democracia pertencia ao leque dos regimes políticos que, de algum modo, se desviaram de seus propósitos mais nobres. Assim, em Política, III, [1279 a]:

Os desvios que correspondem às constituições enumeradas são a tirania, desvio da realeza, a oligarquia, da aristocracia, a democracia, da politéia. A tirania é uma monarquia que tem por objetivo o interesse do monarca; a oligarquia tem por fim o interesse dos ricos; a democracia, aquele dos pobres; mas nenhum desses governos visa servir o interesse comum ${ }^{39}$.

\footnotetext{
38. ARISTOTE, Politique, livre III, p. 73.

39. Ibid., p. 68.
} 
Desviaram-se, pois, porque o interesse privado se sobrepunha ao interesse comum, o que os desqualificava enquanto justos meios políticos. Sobreposição que se acirrava, ademais, nos casos em que cidadania era estendida aos estrangeiros e $\operatorname{artesãos}^{40}$, nas democracias denominadas pelo estagirita de extremadas, o que, na prática, gerou impedimentos à reta condição moral do cidadão, visto que tais indivíduos não haviam sido educados nas virtudes de comandar e obedecer bem ${ }^{41}$, isto é, na boa disposição moral que faculta a boa conduta nos assuntos da comunidade. E se assim o é, o exercício do poder por uma destas porções sociais é impossibilidade do bem comum. A tônica aristotélica recai sobre a determinação de que muitos não estavam preparados para o efetivo exercício da cidadania e da responsabilidade advinda de tal situação. Nesse sentido, o que comparece para o estagirita é a certeza de que a cidadania exercida por um número expressivo de cidadãos não era garantia de sucesso ou mesmo de justiça, a saber, a soberania política não era um problema simplesmente numérico. De sorte que para Aristóteles a justiça política não é quantitativa, mas qualitativa. Retomaremos este argumento no capítulo sobre a justiça.

Dado o argumento, pode parecer que Aristóteles se opõe, sem mais, ao regime democrático. Em verdade, tais enlaces e perspectivas do filósofo são mais complexos, demandando desdobramentos determinativos. Apesar de seu desconforto face à soberania dos mais pobres, Aristóteles, porém, reconhece os riscos de uma soberania limitada, ou aquela forjada na baixa ou quase inexistente presença de cidadãos. Não casualmente, comparece a discussão acerca dos infortúnios das oligarquias, bem como dos perigos das tiranias. Quanto às oligarquias, Aristóteles afirma a impossibilidade do exercício da reta soberania, pois o governo era exercido pelos mais ricos e não pelos melhores, como nas aristocracias, de modo que o interesse político se punha como o interesse dos mais ricos. Voltaremos a essa questão. Analogamente, nas tiranias o interesse prevalente tendia a ser o do tirano. O que se configura, portanto, é a existência de um quadro político, aos tempos de Aristóteles, no qual a presença dos regimes desviados é predominante e, por esse motivo, a questão da soberania passa a ser uma discussão ainda mais intrincada, menos óbvia frente aos dilemas políticos da Grécia clássica. Seja como for, dentre os regimes desviados, a forma mais adequada de soberania política se expressava nas democracias moderadas, pois mais efetivamente

40. Cf. ARISTOTE, Politique, livre III [1277 a - 1278 a], p.61-4.

${ }^{41}$. Ibid., p.61. 
exercem o juízo muitos do que poucos, ou do que um só. Assim Aristóteles inscreve suas considerações em Política, III, [1281 a e b]:

... atribuir o poder soberano à massa do povo antes que à minoria dos cidadãos, os melhores, pareceria ser uma solução válida e ofereceria sem dúvida dificuldades, mas talvez também alguma verdade. A maioria, com efeito, em que cada membro não é um homem virtuoso, pode, porém, pela união de todos, ser melhor que essa elite, não individualmente, mas coletivamente, assim como as refeições a expensas comuns são melhores que aquelas em que só uma pessoa paga a despesa. Do fato de que são muitos, cada um tem sua parte de virtude e de sabedoria prática, e de sua união nasce como um só homem com vários pés, várias mãos e dotado de vários sentidos, e o mesmo ocorre com o caráter e a inteligência ${ }^{42}$.

Mesmo que, linhas à frente, Aristóteles acabe por relativizar tais considerações, marcando a impossibilidade de que muitos julguem sempre melhor ${ }^{43}$, tais reflexões apontam para o reconhecimento da política como instrumento mediador da costura social da comunidade, que então se viabilizava e reproduzia. Ao afirmar que muitos poderiam julgar melhor do que poucos ou do que um só, repõe de fato, e isto se deve sublinhar, a necessidade da mediania na política, já que, só a população, anatomicamente mediana, possibilitaria a coesão, ainda que débil, das porções sociais, que, se inteiramente isoladas, debilitadas, esgarçariam a força comunal; população medial que, na soma das debilidades, das fraquezas e das virtudes de cada um, encontrando um ponto médio, ou a unidade entre virtudes e vícios, tenderia, assim, a encontrar soluções mais adequadas do que as do indivíduo ou de um conjunto de indivíduos cujos interesses privados necessariamente determinariam sua práxis. Por outro lado, Aristóteles pondera que a extensão da soberania aos mais pobres é fator de estabilidade para a comunidade e honra para os cidadãos, pois em Política, III, [1281 b] declara: "De outra parte, a recusa a todo acesso e toda participação no poder é coisa temível, pois toda cidade onde as pessoas excluídas das honras e os miseráveis são numerosos é inevitavelmente cheia de inimigos". ${ }^{44}$ Em termos concretos, para assegurar o equilíbrio comunal, alguns legisladores permitiam a participação popular na escolha e eleição dos magistrados, pois como se afirma em Política, III, [1281 b]:

\footnotetext{
42. ARISTOTE, Politique, livre III,p. 74-5.

${ }^{43}$. Cf. ARISTOTE, Politique, livre III, p. 75-6.

${ }^{44}$. Ibid., p.76.
} 
Sólon e alguns outros legisladores lhes conferem, coletivamente, a eleição dos magistrados e a verificação de suas contas, sem, no entanto, permitir-lhes individualmente o exercício do poder: todos, reunidos, têm, com efeito, discernimento suficiente e, misturados com os melhores cidadãos, eles prestam serviços ao Estado, assim como um alimento impuro misturado a um alimento puro torna o todo mais proveitoso que uma pequena quantidade completamente pura; mas, tomado isoladamente, cada indivíduo não pode trazer senão um julgamento imperfeito ${ }^{45}$.

Significa que a política era mediação da vigência da comunidade: por sua intermediação era alcançado o ponto de equilíbrio necessário à consubstanciação da cidadania, da pólis: a soma das fraquezas e das virtudes dos cidadãos conduzia à mediania moral, necessária à condição real da política, que permitia a vida em comunidade. Logo, a democracia não conduzia apenas a uma mediania moral, mesmo que imperfeita, mas, por esta via, facultava o equilíbrio no exercício da soberania, pois, ao menos em uma de suas formas, comparecia a igualdade e os mesmos direitos no exercício da cidadania. Quer dizer que o critério da participação na atividade política se punha a partir da condição de homem livre, independentemente de sua riqueza ou pobreza. E tal condição ou cidadania que se alargava socialmente, interferia positivamente na comunidade, visto facultar o equilíbrio, conquanto parcial, nas decisões, nos conflitos e nas tensões vividas pela cidade-estado. Assim, é legítimo afirmar que este regime se realizava pelo metro, ou ao menos dele se aproximava, ao viabilizar a inserção política eqüitativa de cada parte da comunidade, contexto que evitava a colisão imediata dos extremos, pois a lei era soberana, não meramente constituída pela vontade das assembléias. Sendo assim, o estagirita se opõe à democracia em suas formas mais desmedidas, nas quais a soberania era a soberania das vontades (dos decretos das assembléias populares) e não das leis, terreno fértil para os demagogos e suas pretensões pessoais, porquanto o império das vontades aproximava as formas extremas de democracia e das tiranias, porque ambas tendiam à desconsideração das leis e das necessidades da comunidade. Morral assinala, com precisão, a recusa aristotélica desta forma degenerada, ao afirmar que, em Política, já aparecem:

as críticas típicas anti-atenienses: que os decretos aprovados pelo capricho popular suplantam as leis, tornando o demos na prática um tirano; que a massa crédula de cidadãos é manipulada pelos demagogos, que lisonjeiam a assembléia popular, fazendo-a crer que tudo deve estar sujeito à

$\overline{45 .}$ ARISTOTE, Politique, livre III, p.76. 
sua decisão/.../‘tudo é governado apenas por decreto', e 'os decretos jamais podem ser regras gerais’ que forneçam a base estável de que toda estrutura constitucional necessita ${ }^{46}$.

Tais argumentos, ressalte-se, fortalecem ainda mais nosso propósito teórico ao evidenciar os fundamentos da política como instrumento regulador, mediador da comunidade, pois ao tomar partido pela democracia (na condição do respeito às leis), o filósofo reconhece a política como o meio de equilíbrio da vida citadina. Meio que deve ser e exercer um justo meio-termo, expurgando excessos, contendo desmedidas, contornando colisões, mediando, enfim. Nas palavras de Morral:

\begin{abstract}
Aristóteles fornece alguns pormenores constitucionais concretos que elucidam sua distinção entre os dois tipos de democracia/.../Aristóteles, como se verá mais tarde, está procurando ressuscitar o ideal do tipo mais antigo de democracia ateniense, inaugurada por Sólon no início do sexto século, que deu a todos as cidadãos o direito de eleição para a assembléia e de funcionar nos tribunais, mas preservou os cargos mais elevados para a aristocracia. Isso foi abolido no final do mesmo século pelas reformas de Clístenes, que abriu todos os cargos da pólis a todos os cidadãos, e iniciou o período de plena democracia radical de que Platão, Aristóteles e outros autores conservadores vieram a suspeitar ${ }^{47}$.
\end{abstract}

A opção por Sólon realiza-se enquanto sua inclinação pela medida, uma vez que o metro soloniano, pessoal e constitucional, sintetizava o tão almejado equilíbrio que, para Aristóteles, a política devia oferecer à construção da vida citadina. Sólon, efetivamente, propiciava uma mediação importante àqueles que desejavam participar da vida política (mesmo que não possuíssem as melhores condições morais), como àqueles que desejavam participar da cidadania a partir da reta medida moral. $\mathrm{O}$ arconte conciliava os direitos políticos dos mais pobres com os da aristocracia, com o que equilibrava a participação dos cidadãos na vida citadina, constituindo assim uma via mais equilibrada e menos tensa para a resolução, mesmo que parcial, dos dilemas da cidade-estado. De sorte que a inclinação do estagirita pela democracia soloniana significa sua reflexão, crença e apelos por uma orgânica democrática nascida da reta medida. Outra não é, aliás, a atitude do estagirita em relação a todas as demais formas

\footnotetext{
46. John B. MORRAL, Aristóteles, p.66-7.
}

47. Ibid., p.57. 
de regime, a saber, o filósofo grego diferencia, no interior das tiranias, aquelas que, de certa forma, regulavam-se por um conjunto de leis (como foi o caso de Pisístrato); daquelas em que a vontade do tirano era imperial e extrema. Diferenciação que sempre implicou sua inclinação pela moderação e pelos limites da sociabilidade, que fizeram da política a via de regulação da cidade-estado.

Em Política, outro enfoque preponderante é o exame das oligarquias. As formas oligárquicas e democráticas de governo consubstanciavam os modos mais comuns de regimes entre os gregos de fins do período arcaico e posteriormente clássico. Tais constituições correspondiam aos dois estamentos sociais mais relevantes, que, diretamente, forjaram a estrutura organizativa da pólis: a aristocracia e o pequeno camponês. Vale ressaltar que o próprio estagirita não mais reconhecia espaço para o advento de governos estritamente virtuosos, tais como a aristocracia ou monarquia puras, pois tanto os melhores, em qualidade moral, como o monarca em sua acepção de virtude extrema - que estaria acima das leis por suas qualidades éticas, eram cada vez mais raros e, nesse sentido, a imposição de um regime vinculado estritamente a estas qualidades tornava-se difícil, ou mesmo impossível. De fato, para além das condições morais, o estagirita percebe a inserção, cada vez maior, da riqueza enquanto requisito a permitir a soberania territorial. Com o desenvolvimento do império ateniense, e, por extensão, da rivalidade entre Atenas e Esparta, a propriedade privada (imóvel e móvel) se ampliou, adquirindo importância maior enquanto critério a interferir e reger as formas de governo. Em outros termos, a propriedade privada da terra, que sempre embasou as formas oligárquicas de poder, alargava sua influência e relevância na lógica do poder democrático, uma vez que viabilizou a expansão do império ateniense.

A expansão da cidadania, por sua vez, só foi possível pela ampliação da propriedade nas mãos de cidadãos colonizadores (e do pagamento de tributos a Atenas a partir das cidades que pertenciam à esfera de sua influência), orgânica que permitiu, com relação a Atenas, o pagamento da mistoforia. Só a ampliação e desenvolvimento da riqueza consentiu à democracia estender a soberania política aos mais pobres. A riqueza, pois, ganhava enorme importância nos regimes democráticos, por ter possibilitado, por cerca de setenta anos, a grandeza e a hegemonia atenienses, que significaram, internamente, um certo equilíbrio entre níveis sociais diversos. De tal modo que a riqueza passava a exercer papel rotineiro e cotidiano nas ambições das cidades; e as virtudes, inversamente, tornam-se, de certo modo, secundárias. A Aristóteles não passa despercebido este estado de coisas, que atina a influência decisiva 
que a riqueza passava a exercer sobre as cidades: qualquer mudança política passaria pela reforma ou mesmo conciliação dos regimes dominantes (oligarquia e democracia), pois efetivamente existentes e majoritariamente difundidos, ou seja, a riqueza passa a determinar ou, no mínimo a influenciar as mudanças políticas. Vê-se que o estagirita entende que a possibilidade de se estabelecer um regime melhor se inseria, inexoravelmente, na orgânica tanto das democracias, como das oligarquias. Descarta a instauração de um regime ideal, desvinculado das circunstâncias históricas. Não é outra a posição do filósofo ao afirmar sua propensão pela objetividade, pois em Política, IV, [1288 b] lê-se: "Deve-se, com efeito, examinar não apenas o melhor regime político, mas ainda aquele que é simplesmente possível, e similarmente, aquele que é de mais fácil aplicação e mais comumente acessível por todo o Estado”. ${ }^{48}$ De fato, a politéia, como governo possível, toma arrimo na mescla dos dois governos majoritários: a oligarquia e a democracia. Desdobremos nossas considerações.

\section{Governo da politéia: a soberania do limite.}

A propensão do estagirita pela objetividade é ainda mais nítida, quando da discussão acerca da melhor forma de governo. É do exame das formas oligárquicas e democráticas de poder que nasce o reconhecimento de que a politéia reúne as melhores qualidades de um regime político, regime este pouco difundido em seu tempo ${ }^{49}$. Significa que a reflexão sobre a politéia, como via apropriada e possível, impõe a Aristóteles a análise dos méritos e deméritos dos regimes existentes, em especial das oligarquias e democracias, reflexão que busca, em suma, encontrar um regime que sintetize as melhores qualidades de ambos. A politéia, de fato, se realiza como formulação decisiva a resolver os dilemas do ideário aristotélico, diga-se mais, o encontro necessário entre a política, o limite e a mediania.

No livro IV de Política [1293 b], Aristóteles afirma a politéia como sendo “em suma, um misto de oligarquia e de democracia”. ${ }^{50}$ Em outras palavras, o estagirita a compreende como o único regime constitucional a possibilitar, de um modo mais eficaz, a ordem e, de certo modo, a harmonia entre ricos e pobres; já que a oligarquia e a democracia isoladamente eram incapazes de conduzir a comunidade ao termo da justiça, do bem viver e da felicidade, pois tendiam ou acabavam por impô-los privadamente -

\footnotetext{
48. ARISTOTE, Politique, livre IV, p. 145.

49. Cf. ARISTOTE, Politique, [IV, 1293 a], p.161.

50. Ibid., p.163.
} 
para os ricos ou para os pobres. A politéia, inversamente, compreendia o equilíbrio das partes e garantia o exercício da soberania a ambos, de sorte que o governo constitucional tomava o que havia de melhor em cada uma das duas formas políticas. Em Política, IV, [1294 a], é asseverado:

É preciso tomar ao mesmo tempo as disposições legislativas dos dois regimes, por exemplo, em matéria de justiça: nas oligarquias, impõe-se uma multa aos ricos se eles não julgam, mas os pobres não recebem qualquer indenização; nas democracias, ao contrário, há uma indenização para os pobres, mas nenhuma multa para os ricos. Tomar essas duas disposições ao mesmo tempo é uma solução comum e intermediária entre as duas legislações, e por isso mesmo característica de uma politéia, já que é uma mistura dos dois regimes. ${ }^{51}$

Entrevê-se, assim, a razão de fundo de sua preferência pela politéia: esta representa a efetivação das perspectivas mediais do estagirita. Em termos concretos, a politéia conduzia os cidadãos ao exercício da cidadania (ricos e pobres), na medida em que os dispositivos legais estimulavam e mesmo permitiam a participação dos mais pobres, posto o pagamento da mistoforia aos mais necessitados; de outro lado, impunha multa aos mais ricos caso os mesmos não exercessem as funções para as quais foram eleitos. Desse modo, o estagirita arma certa eqüidade pelo exercício político, o que significava equilíbrio à comunidade. Portanto, é reposta a tônica da política como mediania, como metro a reger, desde logo, a realização da política em prol da cidade. Para o estagirita o critério de riqueza se atenuava diante de dispositivos legais que incentivavam a participação dos mais pobres e multavam a indiferença dos mais ricos, lógica, em última instância, cujo fundamento reverbera uma mescla conectiva entre os regimes oligárquico e democrático. No espírito do estagirita em [Política, IV, 1294 a]:

A participação na assembléia não depende para alguns de qualquer condição de censo ou de um censo completamente módico, para os outros, ao contrário, de uma forte renda censitária; uma medida comum não é certamente nem uma e outra, mas aquela que fixa para o censo uma renda intermediária entre esses extremos ${ }^{52}$.

Nesse sentido, o critério político, e isto é o que importa sublinhar, passa a ser verdadeiramente mediano, impondo limites aos excessos e omissões tanto das oligarquias como das democracias. O que se afigura, por conseguinte, é a existência de

\footnotetext{
51. ARISTOTE, Politique, livre IV, p.165.

${ }^{52}$. Ibid., p.165.
} 
uma riqueza intermediária como condição da própria cidadania, isto é, Aristóteles introduz no plano político a classe média ativa como mediadora da politéia: por sua condição intermediária, à classe média cumpriria naturalmente legislar para o bem da comunidade e porquanto acima dos interesses privados ou de quaisquer interesses extremos, tanto dos ricos como dos pobres. Melhor dizendo, a classe média comparecia como elo a estabelecer a mediação entre os extremos da comunidade, pois como objetivação da condição mediana, afirmava-se como eqüidistante, como o único estamento social capaz de exercer a soberania com fins propriamente políticos, quer dizer, a política centrada na comunidade.

A constituição da politéia apresentava, então, duas condições ou atributos importantes: a necessária mescla constitucional entre oligarquia e democracia e um centro político que se deslocava para a classe média. Ao desdobrar suas considerações concernentes, afirma Aristóteles [Política, IV, 1294 a]:

...pode-se tomar disposições tiradas das duas regulamentações, umas da lei oligárquica, outras da lei democrática; eu cito como exemplo as magistraturas: a escolha por sorteio é considerada como democrática, a eleição como oligárquica; não exigir qualquer censo é tido por democrático, exigir um, por oligárquico; por conseguinte, será característico de uma aristocracia ou de uma politéia o fato de tomar emprestado um traço a cada um dos dois regimes: da oligarquia, as magistraturas eletivas, da democracia, a supressão do censo ${ }^{53}$.

Com essas palavras, Aristóteles afirma a unidade que faz da politéia um governo moderado, que impõe limites aos extremos - ricos e pobres. A lei regulava e interferia diretamente nos critérios de escolha das magistraturas, como também nas condições de riqueza que permitiam o acesso ao exercício político. Ora, ao assumir as melhores qualidades de cada regime, o governo constitucional impedia que os estamentos, isoladamente, se sobrepusessem aos interesses dos outros; significava que a lei devia zelar por uma orgânica internamente desequilibrada, que na sua ausência perderia a condição positiva de auto-reprodução. No livro III de Politica [1287a], o próprio estagirita refere-se à lei como meio-termo, princípio mediano a regular e equilibrar as relações na comunidade. Em verdade, como veremos no capítulo deste estudo dedicado à justiça, o estagirita empenha-se em determiná-la enquanto via da mediania e do equilíbrio comunitário, o que só podia ser alcançado, pois, mediante boas leis e bons

53. ARISTOTE, Politique, livre IV, p.165. 
cidadãos. Em outros termos, o ideal de justiça era, necessariamente, mediado por boas leis, que, em essência, buscavam o metro.

A cunhagem teórica da politéia não se limita, contudo, ao exame das faces e limites dos governos oligárquicos e democráticos. Aristóteles leva em consideração alguns regimes historicamente efetivados cuja lógica se aproximava do governo da politéia, ou seja, o filósofo arma a formulação da politéia não nas bases de uma idealidade abstrata, mas que se arrima em experiências históricas concretas. Vejamos, como exemplo, as observações do estagirita sobre o Peloponeso, sobre Esparta, a segunda cidade-estado a interferir decisivamente nos rumos políticos dos helênicos.

A constituição espartana fornece ao estagirita uma materialidade, um corpus constitucional que, capaz de evitar os extremos, ou pelos menos mediar com mais eficácia as tensões e embates que sempre existiram entre ricos e pobres, lhe permitirá melhor sintetizar, na articulação com a realidade ateniense, seu ideário político. É o que podemos verificar na passagem a seguir [Política, IV, 1294 b]:

Precisamente o que ocorre com o regime político da Lacedemônia. Bastante gente procura falar como de uma democracia, porque sua organização contém numerosos elementos democráticos; por exemplo, primeiramente, na maneira de criar os filhos; os dos ricos, com efeito, são educados da mesma maneira que aqueles dos pobres e se lhes dá um gênero de educação que poderia ser também aquele dos filhos dos pobres; e similarmente ainda, na idade seguinte, e quando eles se tornam homens, o tratamento é o mesmo; nada permite distinguir o rico e o pobre; assim, para a alimentação, as mesmas regras se aplicam a todos nas refeições em comum e os ricos portam vestimentas tais que se poderia tomar por qualquer pobre; enfim, para as duas mais altas magistraturas, o povo elege uma e dá o consentimento à outra: ele elege os gerontes e dá o consentimento ao eforato ${ }^{54}$.

Aristóteles, percebemos, sublinha algumas práticas cujo teor minimizou os contrastes entre ricos e pobres, proporcionando um acesso menos desigual em relação à soberania política. Trata-se, em última instância, de mediar as relações, de encontrar o ponto médio que permita a convivência, mais especificamente, a sobrevivência da cidade-estado. Aristóteles reconhece o esforço espartano em minorar o fosso político entre os principais estamentos, de estimular o exercício da soberania mesmo que em parâmetros distintos dos vigidos na democracia ateniense. De sorte que a educação igualitária favoreceu, de certo modo, a convivência entre os cidadãos e, nesse sentido, a

\footnotetext{
54. ARISTOTE, Politique, livre IV, p.166.
} 
própria coesão político-militar de Esparta. Quanto às magistraturas de maior responsabilidade (Gerúsia), o estagirita assinala que, em Esparta, o mecanismo político de ascensão se daria a partir de eleições. Logo, só poderiam pleitear tais cargos os de família tradicionalmente mais ricas e, por sua vez, de maior tradição política. Ao povo, restava a participação nas eleições e no eforato, o que, na prática, significou menor influência política. Pela lógica da carta espartana, o estagirita reforça a perspectiva da valência de uma constituição mista: da mescla entre democracia e oligarquia nasce a possibilidade de diminuir as tensões próprias aos dois estamentos principais: o pequeno e médio camponês e o grande proprietário da terra. Então, a política se torna meio, mecanismo a gerir as formas de governo com objetivos claros: ordenar e reproduzir em simetria possível as relações entre os estamentos sociais no interior de adstringências insuperáveis. O estagirita afirma o caráter mediano da constituição mista ao reconhecer que a mesma evita os extremos ao equilibrar a soberania política, vale dizer: ambos se reconhecem como co-participantes da comunidade, como metro a reger seus problemas e a interferir em suas soluções. Ao deslocar o metro político para o meio - a politéia como síntese entre oligarquia e democracia, o estagirita coloca em posição ativa um novo agente político que intervém na nova ordem constitucional: a classe média.

Posto este quadro, e visto que há pouco apenas aludi ao problema, considero relevante retomar, para fins conclusivos, o exame do filósofo acerca da classe média como metro constitucional a gerir a existência da politéia. Assim, clarificam-se determinações constituídas e, ao mesmo tempo, reafirma-se a tese central deste estudo. Vejamos, brevemente.

No livro IV de Política [entre 1295a-b e 1296 a] ${ }^{55}$, ao analisar a composição das cidades, o filósofo observa a existência de três estamentos fundamentais: os muito ricos, os muito pobres e os que estão numa posição intermédia - nem excessivamente ricos, nem excessivamente pobres. Será para estes, de posição mediana, que Aristóteles voltará especialmente sua atenção. A reflexão que se elabora parte da assertiva de que a riqueza ou a pobreza em excesso afetam, necessariamente, a condição moral dos indivíduos: os muito ricos ou muito pobres têm dificuldades (pelo excesso ou privação de riquezas) para obedecer à razão, pois aqueles se dispõem apenas a mandar, tendo, portanto, resistência à obediência; estes, diferentemente, não sabendo mandar, por sua própria natureza, tendem à subserviência, obedecendo de forma servil. Com a classe média, porém, verifica-se o oposto: de riqueza moderada, realiza-se como metro a evitar

55. Cf. ARISTOTE, Politique, livre IV ,p. 169-71. 
extremos, ou seja, sua ambição é posta na reta medida, pois não ambiciona a riqueza dos mais ricos, como também se distancia moralmente dos mais pobres e de suas pretensões em relação aos bens dos mais ricos. Em outros termos, a riqueza moderada permite a vigência de uma reta razão, sendo condição que busca o equilíbrio da comunidade na eqüidistância entre estamentos opostos. Por outro lado, com o que reforça suas determinações sobre a classe média, o estagirita reconhece que a constituição mista [Política, livro IV, 1296 b] ${ }^{56}$ é a forma de governo mais estável, visto estar assentada no ponto médio evitando a luta, por vezes fratricida entre ricos e pobres. Na constituição mista, pois, ambos se sentem reconhecidos em seus direitos, ou, ao menos, existe um nível maior de confiança de que a soberania política seja exercida em prol da comunidade, evitando-se a discórdia e a usurpação de direitos. Inferimos que o filósofo reitera a medida de seu ideário político ao reconhecer a politéia como mediação política entre estamentos, de modo que o exercício político se substantifica enquanto medida a limitar os extremos, a urdir, dentro do possível, a ordem comunitária e sua convivência. Aristóteles é concludente ao discorrer sobre a função social da classe média, com o que demonstra a lógica da constituição mista, em [Política, IV, 1295 b - 1296 a]:

\footnotetext{
Vê-se, portanto, igualmente que a melhor comunidade política é aquela que a classe média a constitui e que as cidades capazes de ser bem governadas são justamente aquelas onde existe uma classe média numerosa e, se possível, mais forte que as duas outras ao mesmo tempo, ou pelo menos que uma das duas: seu socorro afasta a calamidade pública e impede a aparição de excessos contrários. É então uma grande sorte que os dirigentes de um Estado tenham uma fortuna média, mas suficiente, pois ali onde uns têm demais e os outros não têm nada, estabelece-se ou uma democracia extrema ou uma oligarquia pura, ou mesmo uma tirania pelo excesso de uma ou de outra, pois uma tirania pode nascer da democracia a mais radical assim como da oligarquia, mas muito menos das formas intermediárias e daquelas que lhes são próximas $^{57}$.
}

A classe média, reitere-se, é entendida como ponto médio a dirimir conflitos e tensões, proporcionando uma vida melhor aos seus cidadãos, isto é, uma vida politicamente mais justa e menos desigual. Em outras palavras, os extremos (de riqueza e pobreza) geram a possibilidade de regimes desvirtuados tais como as democracias extremas, as oligarquias, ou até mesmo as tiranias. Por isso, a riqueza moderada se põe

56. Cf. ARISTOTE, Politique, livre IV, p. 169-71.

57. Ibid., p.170-1. 
como artífice da comunidade, como equilíbrio necessário a pontuar a política, metro da sociabilidade.

Em Política, IV, [1295 a], a "melhor vida é aquela que consiste num justo meio, quer dizer, a média que qualquer um pode atingir”. ${ }^{58}$ Um justo meio-termo. Condição da pólis porque assim os extremos são evitados. Condição positiva, porquanto naturalmente mais própria ao indivíduo e fácil de ser conquistada, pelo que a comunidade se torna mais estável, menos esgarçada. Em suma, a classe média é ideal político, porque a política é meio para a reprodução comunal: nem riqueza nem pobreza, mas vida em mediania, limitada possibilidade que a faz justa classe política, justa porque porção de uma orgânica que vive na administração adstringida de suas forças sociais, em que a dessimetria significa ruptura do tecido societário, encontrando na politéia a expressão política de sua própria orgânica medial.

58. ARISTOTE, op. cit., p.169. 


\section{A P Í T U L O II}

\section{A J U S T I ÇA ENQUANTO DIMENSÃ O PROF A N A A P OLÍT ICA}

\section{A justiça e a comunidade}

Em Ética Nicomaquéia (EN), notadamente no livro V, Aristóteles desenvolve sua teoria acerca de justiça política: o autor grego demarca as linhas capitais da justiça como elo ou instrumento a intervir, imediatamente, na vida cotidiana e nos problemas da pólis. Sua exposição é marcada por dois níveis conexos. Em primeiro lugar, comparece a identidade genérica de justiça - seu foco, em geral, voltado para a cidade-estado; em segundo, o autor particulariza as formas de justiça - são evidenciados seu uso profano, suas matizes e implicações diretas na vida das cidades-estado. Em verdade, comparecem momentos de maior ou menor concretização teorética, nos quais a justiça toma forma e nuances específicos, sendo delimitadas suas funções e orgânica na vida citadina. De modo a dar curso e concreção à nossa exposição, tomemos arrimo nas explanações iniciais do livro $\mathrm{V}$ de $E N$ que, ao conectarem os espaços da justiça e da política, nitidizam o sentido e dimensão desta, sua dinâmica própria e função no tecido teórico aristotélico, e, deste modo, na trama da sociabilidade da pólis.

Ao contextualizar a importância e o papel da justiça, Aristóteles demarca que os atos justos eram aqueles cujos objetivos visavam criar e preservar as condições de 
felicidade para a comunidade política ${ }^{1}$. A justiça comparecia como meio, como instrumento a propiciar as possibilidades de uma vida citadina feliz e capaz de resguardá-la. Genericamente, eis os norte: criação e preservação de condições que permitissem a autogestão das cidades-estado. Nesse sentido, é relevante notar a simplicidade com que Aristóteles demarca o foco capital da justiça e de sua responsabilidade, a saber: ordenar a comunidade política, equilibrar suas partes, pois, do contrário, como preservar a felicidade que, para os gregos, era intrinsecamente uma conquista comunitária? Posto desde logo, a justiça era, in limine, mediação da comunidade, ou seja, modus operandi da política, com o que se afigurava a imposição de limites jurídicos em prol da convivência entre os estamentos. Dito diversamente, para preservar a felicidade era preciso regular a conduta tanto dos indivíduos, como da comunidade; era preciso conter a sociabilidade dentro de limites que permitissem sua continuidade e reprodução, pois o excesso (de riqueza e pobreza) tendia a esgarçar a medida, portanto, o tecido social. De pronto, pois, felicidade significava condições que permitissem a auto-gestão da comunidade em níveis de relativa autarquia ou, em termos menos abstratos, a felicidade era entendida como a construção de condições que tornassem possível a convivência com os outros na e pela vida citadina, vale dizer, a vida política e militar que concedia ao cidadão a vida in communitas, isto é, da coparticipação e da co-pertença à comunidade, do fazer-se cidadão. Assim, a felicidade não era mero prazer ou sentimento privado, mas, em essência, um modo de vida: o da vida política. De sorte que a justiça era, sem sombra de dúvida, o modus operandi da política, da vida citadina que almejava alcançar uma vida melhor, mais equilibrada e menos desigual para os cidadãos, e que, sobretudo, pudesse seguir seu curso.

Trata-se das afamadas páginas iniciais de EN em que o estagirita proclama o interesse político (comunitário) como mais nobre e decisivo do que o interesse individual, pessoal: o bem comum do Estado é mais importante e determinante para a cidade do que o bem do indivíduo isolado ou dos indivíduos isoladamente ${ }^{2}$. Ao retomar o espírito da $E N$ e, reforçando seus argumentos, o estagirita - no livro III de Política [1282 b] - é concludente: em “todas as ciências e técnicas, o fim é um bem, e o bem maior é, no maior grau, o fim daquela que é soberana entre todas - quer dizer, a disciplina política; e o bem em política é

\footnotetext{
${ }^{1}$. Cf. ARISTOTE, Éthique de Nicomaque [1129 b], p.137.
}

${ }^{2}$. Cf. ARISTOTE, Éthique de Nicomaque [1094 b], p.22-3. 
a justiça, quer dizer, o interesse geral”. 3 Aristóteles, deste modo, reafirma e corrobora o centro da discussão, isto é, a justiça é igualmente equiparada ao interesse geral, ao bem da comunidade. É excluído, portanto, o interesse privado, particular, pois nocivo pela presença da ganância, da desmedida, que, inexoravelmente, afeta negativamente a harmonia da ordem societária. Então, a justiça enforma a universalidade dos cidadãos, o equilíbrio que comporta e determina a vida comunitária, ou seja, o metro, a medida a administrar a vida dos cidadãos, como em [EN, V, 1134 a]:

\footnotetext{
A justiça é, de certa maneira, intermediária, todavia de uma maneira diferente das outras virtudes, observado que ela se coloca no meio, enquanto a injustiça se coloca nos extremos. Além disso, a justiça é a qualidade que permite qualificar de justo um homem suscetível de executar, segundo uma escolha livremente consentida, atos justos e de operar uma justa repartição seja entre ele mesmo e outrem, seja entre duas outras pessoas. Bem compreendido, ele deve-se preservar de se atribuir a si mesmo mais e de atribuir menos a outrem, quando a coisa é útil, e, bem ao contrário, quando ela é má, ele deve respeitar, dele em relação ao outro, essa proporção eqüitativa e observar a mesma conduta face a duas outras partes contratantes. ${ }^{4}$
}

Várias são as determinações expressas pelo filósofo. De modo geral, a tônica se afirma pelo reconhecimento da justiça como intermédio, como justo-meio a impor a devida proporção às partes, ou seja, o equilíbrio e o limite. De pronto, o estagirita estabelece que a política, a partir do braço profano da justiça, põe-se como instrumento a permitir a igualdade entre as partes, como regulação a coibir e a interditar a injustiça, os extremos.

Aristóteles ainda estabelece a paridade entre injustiça e excesso: o injusto se firma por oposição à eqüidade, ao equilíbrio. De fato, sua reflexão coloca a justiça como instrumento medial, como ato justo para outrem, pois é ação que evita os excessos e estabelece simetria. Assim sendo, justiça é sinônimo de equilíbrio, proporção e igualdade diante de matizes e situações adversas. As determinações aristotélicas de justiça e injustiça são antípodas, ou mesmo excludentes, porquanto, vale frisar, a injustiça é desequilíbrio, desproporção desmedida, pois tenciona a medida e inibe o movimento da comunidade. O texto aristotélico ressalta e afirma as figuras da iniqüidade ao assinalar que a injustiça em [EN, V, 1134 a], é:

${ }^{3}$. IDEM, Politique, p. 79.

${ }^{4}$. ARISTOTE, Éthique de NIcomaque, p.150. 
um excesso e uma omissão, contrários à proporção razoável, no que concerne àquilo que é vantajoso ou nocivo. Ela é excesso ou omissão, pois ela está sem cessar no excesso ou na omissão. Ela é um excesso em vantagem daquele que a comete e que se atribui mais que lhe convém de uma coisa absolutamente útil; uma omissão, no fato de que ela pega muito pouco de uma coisa nociva. Para o resto, o injusto se conduz geralmente assim; quanto ao fato de que ele não observa as relações convenientes, sua conduta depende das circunstâncias. A ação injusta comporta, portanto, dois extremos: um deles, o menor, consiste em submeter-se à injustiça; o outro, o mais grave, em cometêla. ${ }^{5}$

Em verdade, a injustiça está imbricada à desproporção, à falta de equilíbrio, à desarmonia, encontra-se, pois, em um estatuto contrário à proporção racional, ou seja, sempre se põe nos extremos do sobejo e da carência, jamais na reta igualdade. $\mathrm{O}$ ato injusto é determinado como o excesso de coisas úteis para si ou a menor proporção de nocividade. Em outros termos, compreende-se a injustiça como extremo que tende a beneficiar uma das partes envolvidas ou o indivíduo que age simplesmente em benefício próprio. Assim, ao exceder-se em relação às coisas úteis ou privar-se de qualquer dimensão nociva, a injustiça se pautava pela negação da medida, isto é, pela negação da proporção que equiparava e legitimava a pólis grega. Ou ainda, o ato injusto era essencialmente nocivo, pois ao facultar para si o excesso de coisas úteis, imediatamente, desfavorecia o ato oposto: efetivava a desmedida, contrariando, entre os cidadãos, a igualdade sobre a qual assentava o necessário mas precário equilíbrio societário da comunidade clássica. Noutra passagem ilustrativa, Aristóteles reforça esta lógica determinativa ao identificar, no cumprimento das leis, o termo-médio dos atos justos [EN, V, 1129 a e b]:

O homem injusto é, parece, tanto aquele que age contra a lei, quanto aquele que quer possuir mais que lhe é devido, e mesmo às expensas de outrem. Também é evidente que justo será aquele que se conforma às leis e que observa a igualdade. O justo nos faz nos conformarmos às leis e à igualdade; o injusto nos conduz à ilegalidade e à desigualdade. Como o homem injusto quer ter para si mais que lhe é devido, ele se mostrará injusto também no que concerne aos bens deste mundo - senão todos indistintamente, ao menos aqueles que fazem o sucesso ou o insucesso. ${ }^{6}$

5. ARISTOTE, Éthique de Nicomaque, p.150.

6. Ibid., p.136. 
Da pena do estagirita, portanto, escorre a identidade entre justiça, atos justos, respeito às leis e igualdade ${ }^{7}$. O homem justo respeita as leis da mesma forma que estas observam a igualdade entre os cidadãos, ou, no mínimo, procuram encontrar um ponto médio nas relações entre os indivíduos. Em Política [III, 1287 a], destaca-se: "Veja-se então que procurar o que é justo é procurar o médio; ora, a lei é meio-termo”. 8 Inversamente, dos atos injustos decorria não apenas a propensão à desigualdade, à ausência do termo médio, mas a situação de ilegalidade, de não observância e efetivação das leis como o justo-meio que interferia positivamente na regulação e ordem da comunidade. A desmedida, logo, era própria do homem injusto, já que a ganância tomava para si muito mais do que deveria, impondo de pronto a desmedida como medida entre cidadãos. A ilegalidade apontada era, sem dúvida, implícito apelo à medida, à urgência de se encontrar a legalidade que permitisse a equivalência in communitas. Ora, em EN [V, 1129 b], o estagirita volta a reafirmar a imbricação entre a justiça e as leis, pois as "leis se pronunciam sobre todas as coisas e têm por objetivo seja o interesse comum, seja aquele dos chefes isso de conformidade com a virtude, ou de qualquer maneira análoga”. ${ }^{9}$ A justiça e as leis eram tomadas enquanto instrumentos da reta medida, e deveriam impor-se como contraposição aos extremos, porque assim seria firmado o interesse comum e negado o interesse particular do homem injusto e de sua ganância. A justiça era almejada enquanto ponto de equilíbrio a mediar as ações e os atos entre os cidadãos. Em EN [V, 1131 a], Aristóteles declara que nos

atos que comportam o mais e o menos, há lugar para um justo meio. Se então o injusto é o desigual, o justo é o igual. /.../ Ora, já que o igual consiste num justo meio, ele poderá ser assim justo. O igual supõe ao menos dois termos. É preciso então que o justo, que é ao mesmo tempo médio e igualdade, tenha relação ao mesmo tempo com o objeto e com várias pessoas. Na medida em que ele é justa média, ele supõe alguns termos: o mais e o menos; na medida em que ele é o justo: pessoas de um certo gênero. Necessariamente, o justo implica ao menos quatro elementos. Para que ele se realize, são necessários duas pessoas e dois objetos em relação aos quais ele existe. O mesmo ocorrerá com a igualdade, ao se examinar as pessoas e as coisas. A relação que existe entre os objetos se encontra novamente entre as pessoas. Se as pessoas não são iguais, elas não obterão, na maneira com que serão tratadas, a igualdade. Daí vêm as disputas e as contestações, quando as pessoas em pé de

7. Cf. ARISTOTE, Éthique de Nicomaque, livre V, [1129 a], p. 135.

8. ARISTOTE, Politique, p. 96.

9. IDEM, Éthique de Nicomaque, p.137. 
igualdade não obtêm partes iguais, ou quando pessoas, em pé de desigualdade, têm e obtêm um tratamento igual. ${ }^{10}$

A reflexão aristotélica sobre justiça se desdobra, ainda, trazendo para a argumentação outros elementos determinativos, que importa rastrear. O principal deles diz respeito à justiça enquanto sua aplicação face à igualdade ou desigualdade entre os cidadãos e bens. O que se afigura, raciocínio também presente na Política, é o fato de que a justiça deve reconhecer e dispor, na medida em que se põe como metro entre as partes, que a igualdade entre os iguais é uma, mas entre os desiguais é outra. A justiça não pode e nem deve ser um metro abstrato diante de indivíduos desiguais e de bens comensuravelmente desiguais. Desta forma agiria, se tomasse por iguais, desiguais, desconhecendo a diferença que os institui. Assim, é posta, em EN e em Política, a conhecida determinação da justiça enquanto uma igualdade entre os iguais e uma desigualdade entre os desiguais. A saber, Aristóteles reconhece que a justiça não pode ter apenas por critério o número ou a quantidade. A justiça examina as situações objetivas, as partes envolvidas, a proporção e a igualdade, legislando justa desigualdade proporcional na repartição dos bens. A prática da igualdade entre desiguais é afirmação da injustiça. De tal forma que a igualdade entre iguais e a desigualdade entre desiguais é medial: cada parte recebe aquilo que lhe é devido; nem mais, nem menos. Tal justiça é denominada "distributiva”, ou seja, comparece o modus operandi da política, seu braço profano que intervém, para mediar as relações citadinas. Desde logo, pois, marque-se, a lógica prevalecente na armação da justiça é a do equilíbrio, da igualdade, da justa mediania que se reparte, forma concreta do ser e de ir sendo da comunidade. Nas palavras de Aristóteles, [EN, V, 1131 a], no

que concerne à justiça parcial e ao direito que dela decorre, ela tem um primeiro aspecto, distributivo, que consiste na repartição das honras, ou das riquezas, ou de todas as outras vantagens que podem caber aos membros da cidade. Sobre esses pontos, é possível que haja desigualdade, e também igualdade, de cidadão a cidadão. ${ }^{11}$

\footnotetext{
${ }^{10}$ Ibid., p.141-2.

${ }^{11}$. ARISTOTE, Éthique de Nicomaque, p.141.
} 
Nessas considerações, portanto, entrevê-se, em primeiro lugar, o mérito e a riqueza a regular e a imprimir uma ordem eqüitativa entre os cidadãos. Quanto ao mérito, advém a prática de que certos cidadãos estavam mais aptos à administração da coisa pública, pois mais experientes e ajustados ao ofício das magistraturas. De modo concreto, o peso da tradição familiar, a experiência e tradição políticas, como também sua inserção econômica na cidade, e, frise-se, a realização de liturgias, contribuíram, e não poderia ser diferente, para a formação e identidade dos mais iguais entre os iguais, o que significa que eram reproduzidas, juridicamente, as diferenças objetivas que teciam a vida social, de modo que a justa cidadania divisada, de fato, nunca conferiu os mesmos direitos aos cidadãos, conquanto procurasse perspectivas, e de algum modo materializasse correções mediais. Seja como for, a justiça distributiva atuava, de um lado, no âmbito das relações de poder, do exercício das magistraturas, atenuando disputas e mediando conflitos na direção da autoregulação da cidade-estado. De outro, mitigava tensões e conflitos no âmbito da partilha da terra, de sua concessão na incontornável disputa entre cidadãos. Competia à justiça regular a terra como propriedade privada e assegurar o uso comum aos cidadãos incapacitados de adquiri-las. O Estado, desta feita, regrava a condição privada da terra embora seu uso (no caso do Estado) fosse comum, equilibrando extremos. Substanciando-se a questão acerca das formas de propriedade - privada e estatal - tomemos mais uma vez a palavra aristotélica no livro II [1263 a] de Política:

Tais são as dificuldades, e outras do mesmo gênero, a que conduz a comunidade da propriedade. $\mathrm{O}$ regime atual, melhorado pelos costumes e por um sistema de leis justas, seria bem superior, porque ele ofereceria a vantagem dos dois outros: eu quero dizer dos dois regimes, propriedade comum e propriedade privada. Com efeito, a propriedade deve ser comum até um certo ponto, mas, em regra geral, privada. /.../ Hoje mesmo, existe em alguns Estados um esboço desse regime que prova que ele não é impossível: em particular, nos Estados bem administrados, tanto ele existe, tanto poderia existir; cada cidadão, possuindo sua propriedade particular, coloca a serviço de seus amigos alguns de seus bens e se serve de outros como de bens comuns; assim, na Lacedemônia, as pessoas se servem dos escravos umas das outras, como se lhes pertencessem, e fazem o mesmo com os cavalos e os cães./.../ É preferível então, é evidente, que a propriedade seja privada, mas que o uso seja comum; quanto a orientar os homens nesse sentido, é função própria do legislador. ${ }^{12}$

${ }^{12}$. ARISTOTE, Politique, p. 59-60. 
Ao desdobrar esta importante consideração que examina as dificuldades próprias a cada forma de propriedade e os benefícios para a comunidade, Aristóteles conclui pela ordem da propriedade privada cujo uso deveria ser comum aos cidadãos: tanto uso comum da propriedade privada imóvel (a terra) como também da propriedade privada móvel (escravos e animais); com o que, in limine, demonstra inclinação pelo metro, por uma forma de propriedade capaz de beneficiar não apenas o cidadão proprietário isoladamente, mas a comunidade como um todo. O uso comum da propriedade emergia, pois, como práxis a evitar extremos, tensões e conflitos. Por outro lado, mas em plena conexão argumentativa, o filósofo anuncia a existência histórica de tal propriedade e de seus benefícios entre os cidadãos lacedemônios; de modo que, em concludência, o estagirita confirma o uso comum da propriedade como medida a equilibrar a convivência entre cidadãos, bem como aprimora o sentido de sua regulação jurídica, visto que o legislador era chamado a agir de forma a permitir o uso comum da propriedade privada: as leis visavam ao interesse comum, ou a uma regulação que permitisse a autarquia da pólis. Em outras palavras, as leis deveriam agir no méson, expressando a justiça distributiva porquanto, neste termos, a cidade adquiria reprodução e ordem. Não é excessivo transcrever aqui uma lei de 334-3 a.C, vigente na Ásia Menor, na qual a justiça impunha multas àqueles que não pagavam impostos pelo uso de terras estatais. A cobrança visava ao equilíbrio da comunidade.

Dentre os cidadãos, nove homens deverão ser eleitos como inspetores, em nome do povo, para descobrirem se algum indivíduo ocupou a parte das terras públicas que antes estavam sendo ocupadas pelos frígios, sem o pagamento de impostos/.../Os eleitos devem prestar juramento a Ártemis de que encontrarão todo aquele que estiver ocupando as terras públicas, de acordo com o decreto, e que lhes aplicarão uma multa de acordo com o valor destas, de maneira correta e justa, segundo seu parecer. E quando aqueles que tiverem sido eleitos aplicarem uma multa, os indivíduos deverão pagá-la à pólis, caso contrário deverão ser expulsos das terras/.../Se alguém objetar, alegando que comprou (a terra) ou a tomou como proprietário da pólis, deverá haver um julgamento (diadikasía) e, se ficar provado que não tem a posse legal da terra, deverá pagar a multa agravada em cinqüenta por cento/.../Um total de onze cidadãos constituirá o corpo de juízes, eleitos pelo povo entre aqueles que não têm a posse de nenhuma terra pública. Dos onze, três deverão ser designados para atuar como advogados. E os juízes e os advogados deverão jurar por Ártemis, de acordo com a lei. E os magistrados deverão mandar inscrever em uma estela o decreto e as multas a serem pagas 
com relação aos terrenos, e esta deverá ser erigida no santuário de Apolo Pítio. Os magistrados deverão gastar o dinheiro em templos públicos e naquilo que a pólis precisar $^{13}$.

A lei citada demonstra a propensão da justiça pela reta medida comunitária. Significa que o uso de terras estatais pressupunha o pagamento de tributos que permitiam ao Estado equilibrar a ordem comunitária, ou seja, o usufruto da terra presumia - como contrapartida - tributos que beneficiassem necessariamente a comunidade. Assim, a justiça equiparava as relações entre os cidadãos e o Estado e uma eqüidade, possível, esboçava-se. O não pagamento de taxas implicava, por isso, desigualdade: o Estado perdia a contrapartida que o beneficiava. De sorte que ao cobrar os impostos, o Estado devolvia à pólis, positivamente, o dinheiro arrecadado, empregando-o na construção de templos públicos ou em qualquer outra benfeitoria. Espírito análogo sustenta uma lei ateniense de 353 a.C sobre dívidas com o Estado, que assim regulamentava:

... se qualquer dos devedores públicos for preso, além de uma multa, de acordo com uma lei ou um decreto, ele deverá ter permissão de indicar, ele mesmo ou outros em seu nome, avalistas da dívida, aprovadas pela assembléia, que quitarão a dívida. E os presidentes devem apresentar a solicitação à assembléia sempre que um devedor desejar nomear avalistas. E o devedor que indicou avalistas deverá ser libertado da prisão uma vez paga a dívida para a qual tiver indicado avalistas. Mas se o devedor não pagar a dívida por si mesmo ou por seus avalistas até a nona presidência (prytanéia), deverá ser preso, e os avalistas terão seus bens confiscados. Com exceção dos coletores de impostos, e de seus avalistas, e seus recebedores, e os locatários, e seus avalistas, a pólis pode cobrar os pagamentos de acordo com a lei em vigor ${ }^{14}$.

Ressalte-se, vigorosamente, que a lei concedia à pólis o direito de cobrar seus devedores em conformidade com a legislação. Significa que a instância legal advogava em prol da comunidade, na exata medida em que as dívidas não recebidas interferiam diretamente na capacidade do Estado de ordenar e de se fazer presente nos problemas da cidade, de modo que o confisco de bens, posta uma inadimplência, fazia-se ação consentida. E a lei, frise-se, resguardava o equilíbrio das partes envolvidas: o cidadão que não possuía recursos para saldar dívidas podia valer-se de amigos na condição de avalistas;

13. Ilias ARNAOUTOGLOU, Leis da Grécia antiga, p.124.

${ }^{14}$. Ilias ARNAOUTOGLOU, Leis da Grécia antiga, p.123. 
caso contrário, o mesmo era preso e os bens dos avalistas confiscados. De fato, o Estado criava as condições para que o cidadão devedor pagasse, equilibrando os litígios e, por extensão, a comunidade. Em outras palavras, a lei, lato sensu, era a justiça para a cidade, para a comunidade, mesmo que o delito envolvesse a esfera particular, pessoal, como afirma Victor Ehrenberg: “A atitude do Estado decorre, sobretudo, do fato de que ele considerou um número de casos como sendo de interesse público, mesmo quando os delitos em questão não visavam em absoluto ao Estado como tal: no caso do homicídio, por exemplo, arriscava-se 'macular' o conjunto da comunidade". ${ }^{15}$ Ehrenberg, pois, permite entrever que o Estado atuava de forma determinante para a comunidade, isto é, determinados delitos (mesmo que privados) eram postos e julgados a partir dos malefícios possíveis em relação à pólis: ao impor a pena ao indivíduo, a justiça pretendia, primariamente, resguardar o Estado, vale dizer, tratava-se de instituir penalidades às pessoas que, potencialmente, eram daninhas à reprodução das formas comunais, que, voluntária ou involuntariamente, feriam o tecido do equilíbrio social necessário. Ou ainda, a pena era individualizada, mas sua conseqüência atingia o coletivo, pois o Estado atuava sem distinguir (em casos específicos) a ação pública da ação privada, ou melhor, o privado era de essência pública quando interferia na vida citadina. Ehrenberg assinala a dimensão unívoca do público-privado ao afirmar que o Estado grego compreendia o delito privado em sua acepção pública, quando tal delito resvalasse ou interferisse diretamente no interesse público. Assim, as leis assumiam a condição de unidade entre público e privado, exercendo-se, enfim, enquanto ordenação medial entre cidadãos.

A orientação de princípio não ia, todavia, apenas no sentido da proteção da vida e da propriedade dos cidadãos, mas ainda, pela inserção de cada cidadão no aparelho judiciário (mesmo nas oligarquias, ele poderia ao menos se constituir demandante), no sentido da preservação da comunidade cívica, fundada sobre a justiça (dikè) e submetida ao $\operatorname{Nomos}^{16}$.

O helenista é claro: a defesa da vida, bem como da propriedade, pressupunha, primariamente, a defesa da comunidade, que na ordem societária grega era a própria condição de existência do cidadão e de sua propriedade. Indivíduo e comunidade estavam

\footnotetext{
${ }^{15}$. Victor EHRENBERG, L’ État grec, p.136.

16. Ibid., p.139.
} 
em unidade orgânica, como assinalado em nossa Introdução, de modo que, e por decurso, os delitos públicos ou privados (nos casos de afronta à comunidade) eram imediatamente subsumidos ao nomos, à comunidade que tomava para si a tarefa de punir. Então, público e privado se imbricavam, de fato:

As ações públicas evidenciam naturalmente todos os delitos contra o Estado, tais como a alta traição ou o fato de enganar o povo, todas as ações em ilegalidade, assim como por prevaricação no exercício dos magistrados ou delitos cometidos na guerra. É evidente que a impiedade também caía nessa categoria. Mas se lhes ajuntava um número, num certo sentido de coletividade: assim os processos de adultério, de proxenetismo, de prostituição de rapazes, de sicofantismo e mesmo de roubo - mas somente em certos casos particularmente graves, afetados de hybris, quer dizer, de um abuso de caráter ultrajante que, sob suas diversas formas, constituía, da parte do malfeitor, um desafio à coletividade. ${ }^{17}$

Dito sucintamente, os crimes de traição ao Estado, de prevaricação no exercício da magistratura, de logro ao povo, bem como aqueles restritos à guerra, continham e revelavam dimensão pública, o que implicava uma punibilidade em prol da comunidade, lesada que fora por uma ação que a desequilibrara. Mas, Ehrenberg indica ainda a particularidade de alguns delitos que, privados, assumiam a condição pública porquanto crimes que afrontavam ou colocavam em risco os membros da cidade, tais como o adultério, a prostituição de jovens, o proxenetismo, o sicofantismo e o roubo. Ocorre que tais crimes obstaculizavam a medida, pois exprimiam desprezo pela virtude, pelo equilíbrio e moderação nos atos, bem como desrespeito pelo patrimônio alheio no caso dos furtos. Logo, sua instância se descola da genética privacidade, constituindo-se em problema de solução pública, publicidade que estabelece forte amarra entre o homem singular e a pólis.

Toma-se, agora, a palavra de outros comentadores com o que se fundamenta, de forma mais generosa, a reflexão desenvolvida.

Ross, em Aristóteles, em consonância com Ehrenberg, considera:

Do mesmo modo que o requerido num processo civil é acusado de ter feito um agravo a um indivíduo, o acusado, num processo criminal, é considerado como tendo feito um agravo à cidade. Aristóteles pensa que a lei deveria controlar toda a vida humana e assegurar, senão a moralidade, já

17. Victor EHRENBERG, L'état grec,137-8. 
que ela é impotente para fazer de modo que os homens ajam "pelo nobre motivo", ao menos a realização de ações correspondentes às diferentes virtudes. ${ }^{18}$

O autor assinala que, nos processos privados envolvendo crimes, pela natureza do delito, estes assumiam a condição pública conquanto o malefício da ação era potencialmente nocivo à comunidade. Ross, sem dúvida, corrobora os argumentos de Ehrenberg. O delito privado tornava-se público, o foco privado se subsumia à polis, que interpunha, se necessário, a justiça como equação política a punir os indivíduos e a proteger os cidadãos. Gernet, por seu turno, avigora as determinações expostas ao observar, assertivamente, em Droit et institutions em Grèce antique, o caráter público-privado dos homicídios ocorridos na Atenas clássica e tece as considerações a seguir:

O acusador, que faz ofício de vingador, pronuncia uma 'interdição' contra o assassino, quer dizer, ele lhe prescreve de não participar nos atos religiosos e de não mais aparecer nos santuários nem nos lugares públicos. Na época clássica ainda, embora seja um ato puramente privado e mesmo de uma parcialidade gritante, a interdição conserva todo o seu efeito, em princípio. ${ }^{19}$

Ao homicida, pois, era imposta sentença que o impedia de participar das festividades religiosas, dos cultos nos santuários, como também lhe vedava o acesso a lugares públicos; o que permite referir que o delito de morte (não obstante seu caráter privado) era considerado, por sua gravidade e ameaça à comunidade, como problema comunitário, não meramente privado. Logo, a justiça interpunha sentença que coibia a convivência do criminoso com os demais cidadãos. A lei ateniense de 409-8 a.C sobre o homicídio culposo ilustra bem nossas considerações:

Mesmo que uma pessoa mate sem intenção, será exilada; os basileîs devem julgar o culpado [...] ou conspirador; os ephéta proferem a sentença. Para obter perdão, é necessário o consentimento de todos, pai, irmão ou filhos (da vítima), e a recusa de um deles é suficiente para que não se conceda o perdão. Se não houver nenhum dos parentes mencionados acima será suficiente o consentimento de parentes no grau de primos e filhos de primos, mas a recusa de um deles é suficiente para a não concessão $^{20}$.

\footnotetext{
${ }^{18}$. W.D. ROSS, Aristote, p. 292.

19. L. GERNET, Droit et institutions en Grèce antique, p.76.

${ }^{20}$. Ilias ARNAOUTOGLOU, Leis da Grécia antiga, p.82.
} 
A lei é clara: impunha o exílio ao homicida, mesmo que caracterizada a não intenção de matar. Em outras palavras, o indivíduo que matava, não obstante os motivos, era considerado um indivíduo perigoso, expondo os cidadãos e suas famílias. O exílio, então, era medida primária, a não ser que houvesse o perdão de um familiar da vítima composta por membros da pólis. Significa, concretamente, que assuntos privados se faziam juridicamente públicos, comunitários; de sorte que a ação privada, quando interferente na comunidade, era por ela tomada em mãos, no que se imolica, como tantas vezes posto, o sentido medial da vida grega, vale dizer, a busca de justo termo para a garantia da reprodução da cidade.

Cabe, ainda, no interior desta questão, ressaltar casos em que o uso indevido e desmedido da propriedade familiar adquiria dimensão jurídica coletiva, ultrapassando, em muito, o universo privado das relações de parentesco. De modo concludente, Ehrenberg afirma:

O direito de família ressalta em geral a categoria das ações privadas, em contrapartida, certos casos, como o agravo causado aos pais, aos órfãos, aos herdeiros e mesmo, em Atenas, a vadiagem ou a dilapidação eram considerados como dando lugar a ações públicas, sem dúvida porque tudo isso parecia ameaçar a existência e a propriedade da família, quer dizer, de um grupo cuja importância política e religiosa era vital para a cidade. ${ }^{21}$

O uso imoderado da propriedade familiar podia acarretar, pois, em casos específicos, malefícios à cidade: a ociosidade ou a dilapidação de bens dificultava ou até mesmo impedia as famílias mais ricas e influentes de contribuírem positivamente em festividades cívicas, por exemplo. Por outro lado, tais condições interferiam negativamente porquanto o poder político familiar se via diminuído, o que condicionava menor influência e barganha nas disputas políticas pela sucessão e indicação de cidadãos para cargos e magistraturas importantes, algo, pois, que imediatamente privado, fazia-se imediatamente público, interferindo prejudicialmente em sua dinâmica política. Assim, a imoderação no uso dos bens era daninha ao bom andamento da pólis, convertendo-se assim em problema

21. Victor EHRENBERG, L'état grec, p.138. 
coletivo. O Estado interferia sempre que as condições de regulação da comunidade se viam ameaçadas externamente por guerras ou, internamente, por conflitos ou por indivíduos que constituíssem ameaça real a seus membros. O autor de O Estado grego não só reafirma suas considerações anteriores, como as desdobra, referindo que:

Por um tempo ao menos, depois de 401, foi regra que os casos de direito civil fossem primeiro deferidos a um árbitro que, sem conseguir conciliar as partes, julgava em primeira instância. A natureza de uma ação pública decorre, antes de tudo, do fato de que, na ausência de um ministério público, todo cidadão de pleno direito estava habilitado a mover a demanda judicial no interesse público, enquanto que nos negócios privados, somente o interessado podia fazê-lo. Em alguns casos excepcionais, tal magistrado podia ser obrigado a requerer, em razão de sua competência, e acontecia que, se a cidade ela mesma parecia em perigo, os acusadores públicos fossem oficialmente designados: mas essas são exceções que confirmam a regra segundo a qual todo cidadão no gozo da integralidade de seu direito podia mover a ação. /.../ Nas ações públicas, o requerente não podia retirar sua ação, enquanto isso era possível nas ações privadas até o instante que precedia o julgamento. Em seus direitos como em seus deveres, o indivíduo era ligado à pólis, e capta-se aqui, melhor talvez que em outra parte, o caráter muito pouco jurídico da cidade, que não era uma construção abstrata superior aos cidadãos, mas sua comunidade mesma ${ }^{22}$.

Claramente, pois, aparece aqui a relação carnal entre indivíduo e comunidade. Todo o cidadão (politicamente pleno) poderia impetrar ações judiciais conquanto as ações fossem de interesse público, comunitário. Significa que, em determinadas situações, o cidadão dispunha do direito de assumir a condição de medida viva, uma vez ameaçados os interesses comunitários. Em ações privadas, frise-se, apenas o cidadão envolvido estava na condição jurídica de sustar ações. Diversamente, diante do interesse público, o cidadão (que originou a ação) não podia suspendê-la antes de seu julgamento, pois o bem comunitário se sobrepunha ao seu direito particular, de tal modo que a lei resguardava e defendia primariamente os direitos públicos, citadinos. Encerrando este movimento teórico, a justiça da pólis era a justiça comunitária, que resguardava a ordem pública, o bem público e as condições da vida citadina, lógica que implicava a relação imediata público-privado, sobre a qual a justa medida podia tomar forma jurídica, ordenando a vida real ao sustentar na lei a

\footnotetext{
${ }^{22}$. Victor EHRENBERG, L'état grec, p.137.
} 
necessidade da mediania, do limite, que vigia e imperava porque condição e via da própria sociabilidade.

\section{A medida e o juiz: da justiça distributiva e da justiça corretiva.}

Retomemos, para dar melhor contorno à argumentação desenvolvida, a caracterização da justiça distributiva e sua relação com a justiça corretiva. Acima, afirmamos que a justiça distributiva era aquela que regulava e dispunha sobre a distribuição de cargos e da propriedade entre cidadãos. Ou seja, tanto os bens fundiários, como a vida política eram, essencialmente, palco de disputas e tensões acirradas entre famílias que ansiavam por participar das magistraturas e, deste modo, dos destinos da pólis. A justiça distributiva dispunha acerca do mérito ou, no interior da porção social, a quem cabia exercer o mando político. De fato, ordenava aquilo que nas democracias, nas aristocracias e nas oligarquias era tido como justo, de sorte que em cada espaço social específico ganhava nuances e delineamentos distintos, posto que a cidadania era exercida a partir de critérios diferenciados, não homogêneos. Aristóteles, assim, reconhece que a disputa em torno do que cada regime considerava justo não era simples; antes, envolvia a lógica e a peculiaridade própria de cada regime, ainda que, de modo geral, houvesse convergência em relação a que o justo era a reta medida e o proporcional. As recíprocas distinções e contradições surgiam, não obstante, no momento em que a reta medida tinha de ser concretamente objetivada, como instrumento ou critério para a escolha dos cargos políticos e da distribuição da riqueza. Nesse ponto, e se adequando a cada regime específico e sua orgânica, irrompiam diferenças conceituais e práticas que a justiça, a cada caso, incorporava, intervindo socialmente a partir deste necessário ajustamento. Nas palavras do estagirita [EN, V, $1131 \mathrm{a}]$ :

... no que concerne às partilhas, todos estão de acordo que elas devem-se fazer segundo o mérito de cada um; todavia, não se está de acordo, freqüentemente, sobre a natureza desse mérito, os 
democratas o colocando na liberdade, os oligarcas, na riqueza ou no nascimento, os aristocratas, na virtude. Assim, o justo é, em certa medida, uma proporção. ${ }^{23}$

No interior de cada regime, por sua vez, a realização da justiça sofria também imanentes tensões. Nas democracias regidas pelo preceito de isonomia, qualquer cidadão, em princípio, teria acesso ao exercício das magistraturas. A realidade, porém, era bem diferente: os cargos eram facultados apenas às famílias tradicionalmente mais influentes. Já os oligarcas observavam unicamente a riqueza e o nascimento como disposições de acesso aos cargos políticos, ou seja, somente as famílias mais ricas e tradicionais detinham o comando político da cidade. Quanto às aristocracias, a medida ética ou virtude dispunha sobre os fundamentos do exercício político. Reconhece-se, no entanto, que tal critério era, por vezes, de difícil aferição, gerando, futuras tensões entre famílias. Seja como for, a justiça distributiva compreendia a difícil tarefa de mediar os interesses entre cidadãos, de preservar e equilibrar aquilo que lhes convinha, notadamente no plano político e da distribuição de terras. Ross sintetiza a questão:

... a justiça distributiva nos parece algo um pouco estranho; nós não somos habituados a ver o Estado como a distribuir a riqueza entre os cidadãos. Nós o vemos mais como disbribuidor dos encargos sob a forma de tributação. Na Grécia, no entanto, o cidadão se considerava, como se disse, mais como um acionista do Estado do que como um contribuinte; e a propriedade pública, por exemplo, a terra de uma nova colônia, era muito freqüentemente dividida entre os cidadãos, e a assistência pública aos necessitados também era reconhecida. ${ }^{24}$

Ross assinala, pois, que a justiça distributiva atuava na direção de mediar relações, pois cabia ao Estado estabelecer o equilíbrio da riqueza entre os cidadãos, ou seja, a comunidade (através da justiça) intervinha para assegurar que a propriedade fosse, de algum modo, de uso público. Vale dizer, as colonizações permitiram a expansão da propriedade da terra nas mãos de novos cidadãos, equilibrando a riqueza, como também o próprio Estado se viu fortalecido nas possibilidades de assistir, por meio de arrendamento, o pequeno camponês. De modo que a justiça distributiva asseguraria bom comedimento à

23. ARISTOTE, Éthique de Nicomaque, p.142.

${ }^{24}$. W.D. ROSS, Aristote, p. 293-4. 
comunidade, a boa proporção que elevava as condições da autarquia citadina. Quanto à justiça corretiva, seu foco se inseria nos delitos cotidianos (crimes, comércio e contratos estabelecidos entre os cidadãos) de forma voluntária e/ou involuntária. A descrição de Aristóteles [EN, V, 1132 a] esclarece tal sentido:

... pouco importa que seja um homem distinto a haver despojado um homem sem nada, ou reciprocamente; pouco importa que o adultério tenha sido cometido por um ou por outro desses dois homens; a lei só leva em consideração a natureza da falta, sem consideração pelas pessoas, que ela coloca em pé de igualdade. Importa-lhe pouco que seja essa ou aquela pessoa que cometa a injustiça ou que a sofra, tal ou qual que cause o dano ou seja vítima dele. Em conseqüência, essa injustiça que repousa na desigualdade, o juiz se esforça por corrigir. Com efeito, quando uma pessoa recebe alguns golpes e quando outra os inflige, quando um indivíduo causa a morte a que um outro sucumba, o dano e o delito não têm entre eles qualquer relação de igualdade; o juiz busca remediar a essa desigualdade, por meio da pena que ele inflige, reduzindo a vantagem obtida. ${ }^{25}$

Desdobrando, sucintamente. Uma vez que as ações afetam diretamente os indivíduos, suas conseqüências são imprevisíveis num gradiente que oscila entre pequenos infortúnios até danos nocivos, desproporcionais; logo, as ações significam imediatamente a relação de ganho e perda. Para o estagirita, gerar ou receber um dano implica, de modo efetivo, a diferença entre o ganho e a perda: ao se lesar alguém, o ato gera - para aquele que o praticou - um bem ou um ganho, pois não sofrer uma injustiça, ou dela sorver vantagem é um ganho. Por outro lado, sofrer o delito, um ato negativo, é perda, porque injusto e desequilibrado em seu impacto e efeitos. Então, a lei observava a ação, corrigindo a assimetria dos resultados, ou seja, a desproporção vivida entre autor e vítima. Em outros termos, e mais universais, a justiça corretiva apontava para o metro, para a proporção, que equilibrava, ou, no mínimo, minimizava os efeitos mais gravosos das ações. O objetivo era claro: estabelecer a proporcionalidade, a paridade possível entre as partes envolvidas, entendendo salvaguardar parâmetros de eqüidade, equilíbrio e justo-meio, que, como atinado, norteavam e embasavam o télos do direito grego. A pena, portanto, era entendida e aplicada como meio-termo, como instrumento reparador da medida contra os excessos e

\footnotetext{
${ }^{25}$. ARISTOTE, Éthique de Nicomaque, p.144.
} 
omissões dos atos, das desigualdades inerentes a cada caso em particular. Destarte, em EN [V, 1132 a], lê-se:

Assim, o igual é o justo-meio entre o mais e o menos; o ganho se confunde com o mais; a perda, ao contrário, com o menos, o primeiro se encontra no excesso em relação ao bem e ausência em relação ao mal; na perda se verifica o contrário. É porque o igual está no meio, nós dizemos que é o justo. Conseqüentemente, a justiça corretiva será o justo-meio entre a perda de um e o ganho de outro. ${ }^{26}$

Na pena do filósofo, então, é reforçada a idéia de que a justiça corretiva era a justa medida entre extremos, entre ganho e perda; reiterando, era ação no sentido do equilíbrio que permitia e preservava o intercâmbio entre os indivíduos, era o forjamento da igualdade que dava forma e coesão ao modus operandi da pólis grega. Em suma, e em conclusão [EN, V, $1132 \mathrm{a}]$ :

Também, quando alguma diferença se produz entre os homens, eles têm o recurso ao juiz. Encontrarse com esse juiz é se colocar diante da justiça, porque o juiz entende ser, por assim dizer, a justiça encarnada. Na pessoa do juiz, procura-se um terceiro imparcial e alguns chamam os juízes de árbitros ou de mediadores, querendo significar com isso que, quando se tiver encontrado o homem do justo meio, conseguir-se-á obter justiça. A justiça é, então, um justo meio, se ao menos o juiz é um justo meio aí. O juiz mantém a balança igual entre as duas partes ${ }^{27}$.

A justiça, em pena e prática gregas, se fazia na busca do rigor da mediação e do equilíbrio. As desavenças, as diferenças, os litígios; numa palavra, os desequilíbrios nas relações entre os homens eram mediados pela justiça, reparados em sua assimetria e, desta forma, repostos no metro e na medida que sustentavam a sociabilidade grega. O juiz, em tal lógica, era a justiça encarnada, pois assumia a condição de árbitro e mediador; a pessoalidade do juiz sintetizava prudência e sensibilidade, retidão e domínio para mediar e restituir, no interior de situações adversas, o metro perdido ou que a isso tendia. Deste modo, a justiça articulava e ordenava a vida citadina grega, suas pretensões, num universo incerto e de desequilíbrios crônicos. Competia à justiça minimizar a realidade ingênita e empiricamente frágil, débil e modesta das formações gregas, pois atravessadas por

26. ARISTOTE, Éthique de Nicomaque, p.144-5.

27. Ibid., p.145. 
dificuldades e debilidades insuperáveis. Significa, então, que “a justiça não é uma virtude entre as outras, mas a virtude da comunidade, aquela que regula as relações entre os seus membros, graças à qual uma comunidade existe ou pode continuar existindo”. ${ }^{28}$

\section{Da atimia e do ostracismo: sua relação com a medida.}

No correr das páginas seguintes, será delineada a lógica da atimia e do ostracismo, formas sócio-jurídicas que, por sua dinâmica intrínseca, testemunham a dimensão jurídica grega, mais especificamente, o talhe medial de seu caráter.

\section{Da atimia}

Apesar do uso moderado da atimia, como também de sua vertente mais branda e posterior, o ostracismo ateniense, o fato é que ambos foram meios jurídicos a equilibrar a convivência da pólis, objetivando a igualdade entre cidadãos, isto é, a medida como metro da comunidade. Necessário, pois, para este estudo, tomar a questão.

A forma mais antiga de atimia nasce por volta do século VI, nos pródromos da cidade-estado. Pontua Mossé:

... o termo atimia parece ter abarcado dois tipos de exclusão da participação na vida política. Na sua utilização mais antiga, significava que o cidadão que tinha sido atingido por esta pena se tornava uma espécie de fora da lei que qualquer um podia matar impunemente e a quem se podia tirar os bens ${ }^{29}$.

Em sua acepção mais antiga, a atimia compreendia não apenas o interdito à convivência política, mas também, e por vezes, a morte do cidadão; da exclusão jurídica, poderia avançar enquanto eliminação física do acusado. A atimia, assim, em suas origens, regulava a comunidade a partir de expedientes pouco políticos, ainda vinculados ao poder

28. Francis WOLFF, Aristóteles e a política, p.41.

${ }^{29}$. Claude MOSSÉ, O cidadão na Grécia antiga, p.72. 
do genos aristocrático e das tiranias. A eliminação física do cidadão expunha a crueza de um direito que ainda não alcançara patamares civilizados, ou no qual a medida era afirmada sob o império da vontade da velha aristocracia ou de tiranos que se viam impelidos ao uso de procedimentos escusos. Porém, Mossé observa:

... a partir do século VI, pelo menos em Atenas, a atimia adquiriu um significado menos radical: ser atingido pela atimia significava para um cidadão a perda dos seus direitos políticos e a exclusão dos santuários da cidade. $\mathrm{O}$ atimos perdia o direito a ter o assento na assembléia e nos tribunais e não podia aceder a nenhuma magistratura. Mas não deixava de fazer parte do corpo cívico e a sua união com uma ateniense, por exemplo, era legítima e conservava os seus bens ${ }^{30}$.

Com o passar do tempo, a atimia passou a consignar a perda dos direitos políticos sem implicações econômicas, isto é, a pena impunha a perda jurídica da cidadania sem exclusão dos direitos de propriedade e de riqueza; estamos mais próximos dos processos de ostracismo que irão caracterizar os exórdios da democracia a partir de Clístenes. De fato, a atenuação da atimia, no século VI, coincidiu com o desenvolvimento e fortalecimento do demos, da vida citadina regulada em níveis de menor desigualdade, advindo das administrações de Sólon e das tiranias arcaicas, em que o avigorar do demos (como exposto em capítulo anterior) abriu espaço para a transmutação do direito, mesmo que a longo prazo, em direito in communitas - o jurídico passava a preservar comunidade e indivíduo. Em termos diversos, a preservação da propriedade era condição de existência do indivíduo, por extensão, da família; logo, o cidadão (mesmo perdendo os direitos políticos) não deveria mais se ver impedido de reproduzir-se materialmente, o que, na prática, corroborava para a manutenção e ordem da pólis. Mossé desvela o substrato essencialmente comunitário da atimia ao responder a duas questões de fundo:

... quanto à atimia, levantam-se dois problemas: seria hereditária? E que delitos poderiam levar à atimia? Quanto ao primeiro ponto, parece que a atimia era uma condenação para toda a vida, mas que atingia unicamente o culpado não sendo extensível aos descendentes. Mas havia um caso, um único caso, em que a atimia podia ser hereditária: o do devedor público, do cidadão que não tivesse pago uma multa decretada pelo tribunal ou, caso fosse um cobrador de impostos, ficasse com as quantias recebidas. Neste caso, se morresse antes de pagar a dívida, a atimia recaía sobre os herdeiros, mas

${ }^{30}$. Claude MOSSÉ, O cidadão na Grécia antiga, p.72. 
cessava a partir do momento em que a dívida ficava paga. Além destes casos de endividamento, os outros delitos que podiam levar à atimia eram de ordem diversa, resultando uns de ofensas privadas (maus tratos, violências sexuais, dissolução do patrimônio, etc), outros de ofensas públicas (corrupção de juízes no decorrer de um processo, falso testemunho, condenações repetidas por ter praticado atos ilegais) ${ }^{31}$.

Mossé descreve analiticamente e com clareza o cunho comunitário que permeava as penas por atimia: quando do envolvimento do Estado, da comunidade cívica, a atimia passa a ser assunto público, ainda que a ação tivesse dimensão privada, individual. De fato, a dívida para com o Estado era uma questão pública na exata medida em que ele dependia de arrecadações para exercer suas finalidades e objetivos. O que está posto aqui são as condições do exercício político para com a comunidade, quer dizer, se os cidadãos não pagassem suas multas, como o Estado poderia se auto-regular com o objetivo da autarquia citadina? Do mesmo modo, aquele que se apropriava do bem alheio, comunitário, punha-se na condição inversa da comunidade: ao se apoderar das receitas do Estado, o cidadão impedia, em tese, a possibilidade de equilíbrio e viabilidade da cidade a que pertencia, assim, o delito privado (neste caso) era essencialmente público, porquanto afetava diretamente a orgânica das cidades, seu ser, futuro e perspectivas.

Por outro lado, ademais, Mossé assinala uma série de delitos que, não obstante o caráter privado, eram igualmente afigurados na dimensão pública uma vez que atingiam a vida em comunidade. Em relação aos crimes sexuais, a dimensão coletiva era, desde logo, alterada, porque ao violar a integridade do indivíduo, violava-se a integridade da comunidade, posto existir entre ambos uma relação de co-pertença. A comunidade sentia-se ameaçada diante da brutalidade e da ausência de valores na ação individual predatória, que, outrossim, arranhava o todo. A ação singular reverberava substancialmente no tecido social, porquanto frágil em sua estrutura, e,dessa maneira, possibilitando aos indivíduos a prática de atos intrinsecamente negativos, contra a reta medida moral - contra a vida citadina. De igual modo, a corrupção de juízes era fato imediatamente comunitário, pois na sociabilidade do nomos a corrupção da magistratura significava a quebra da medida, da justiça, em suma, dos fundamentos que arrimavam e vivificavam a experiência histórica das

\footnotetext{
${ }^{31}$. Claude MOSSÉ, O cidadão na Grécia antiga, p.72.
} 
cidades gregas. Em resumo, a atimia cumpriu um papel nem sempre justo, viciado em seu uso indevidamente político, por vezes, como instrumento de eliminação direta de adversários políticos. Não obstante, cumpriu-se enquanto necessário rigor da lei para aqueles que se puseram para além das fronteiras do que a comunidade julgava adequado, mediano e prudente; fatores estes dos quais dependeriam seu alicerce.

\section{Do ostracismo}

Quanto ao ostracismo, podemos afirmar que se tratava de uma atimia atenuada, mais branda, que não implicava a perda da propriedade da terra ou mesmo da vida. ${ }^{32} \mathrm{O}$ ostracismo significava, sim, a perda dos direitos políticos, jurídicos, por período determinado e sem a privação dos direitos sobre a propriedade e seus bens. É lugar mais ou menos comum atribuir a Clístenes a lei que instaura o ostracismo, nos pródromos da democracia ateniense. Partiremos das ponderações contidas na $C A$ e em Política, que, no essencial, desvelam a orgânica do ostracismo e o entendimento do estagirita acerca de suas razões.

Iniciaremos o percurso pela $C A$, na qual afirma-se o seguinte sobre Clístenes: “o regime tornou-se bem mais popular do que o de Sólon. Realmente, ocorreu que a tirania fizera as leis de Sólon caírem no esquecimento por desuso; já Clístenes, tendo em vista a multidão, promulgou outras novas, em meio às quais foi estabelecida a lei respeitante ao ostracismo”. ${ }^{33}$ Aristóteles, por conseguinte, situa o início do ostracismo após o governo de Sólon e da tirania familiar dos pisístratos, determinação na qual boa parte dos helenistas se apóia para pensar o ostracismo enquanto lei essencialmente antitirânica, forjada nas disputas políticas atenienses. Não creio que a busca de um apaziguamento destas disputas tenha sido a única razão de seu nascimento, não obstante sua importância, pois o ostracismo, instrumento da preservação da medida, significou, in limine, o interdito a toda e qualquer tentativa de ultrapassá-la, seja no âmbito político, dos valores ou das riquezas

32. Cf. TRABULSI, José Antonio Dabdab, Ensaio sobre a mobilização política na Grécia antiga, p.95.

33. ARISTÓTELES, A Constituição de Atenas, p.53. 
(como se verá mais adiante). O ostracismo, de fato, apareceu como contenção do indivíduo em parâmetros aceitos pela pólis democrática, impondo o desterro como mediação de preservação da cidade. Linhas à frente, Aristóteles esclarece:

Sob o arcontado de Fenipo/.../aplicaram então pela primeira vez a lei sobre o ostracismo, a qual tinha sido promulgada por causa das suspeitas em relação aos poderosos, uma vez que Pisístrato se estabelecera como tirano quando detinha a liderança do povo mais o comando militar. O primeiro a ser ostracizado foi um dos seus parentes, Hiparco, filho de Carmo e do demos de Colito: por sua causa Clístenes, tencionando expulsá-lo, promulgara a lei ${ }^{34}$.

Delineia-se, inicialmente, um dos aspectos ou razões do ostracismo: a dimensão antitirânica. A lei operava contra os poderosos, contra aqueles que de algum modo se objetivavam com ações que potencialmente poderiam romper o equilíbrio, a medida de uma comunidade regida e norteada pela lógica do nomos. É certo que, tornar-se tirano implicava não apenas romper com tal equilíbrio político da pólis, da soberania das leis, mas implicava, mormente, a ruptura com os padrões éticos da convivência, da justa medida que valorizava a igualdade e o respeito mútuo, a comunhão de objetivos que deveriam seguir, socialmente, estrada recíproca. O caráter antitirânico do ostracismo, nesse sentido, guarda em si motivação social mais ampla e determinante do que a necessidade, real, do combate à tirania, pois ao se obstar a ação tirânica, ao se exilar o cidadão, eliminava-se não apenas as pretensões ímprobas do homem político, mas todo e qualquer infortúnio, pessoal ou não, que interferisse negativamente no cotidiano das cidades, na práxis comunitária. O exílio, assim, atuava como prevenção em favor da medida, como antídoto a uma cidade que não poderia suster-se na desmedida política, pessoal, ética, etc. Trabulsi, não obstante, enfatiza essencialmente o caráter antitirânico do ostracismo ao afirmar que, é oportuno citar, o

medo da tirania, cujos apoios deviam ainda ser consideráveis no momento do estabelecimento da lei, explica o caráter preventivo antes que punitivo do ostracismo. É interessante notar que a tirania modela outro aspecto desta lei: ela atinge um indivíduo, e não todo um génos, como era freqüente nas lutas políticas arcaicas. Como a própria figura do tirano, que exasperava as tensões políticas ao concentrar todo o poder sobre uma cabeça, da mesma maneira, a lei sobre o ostracismo concentrava

${ }^{34}$. ARISTÓTELES, A Constituição de Atenas, p.53. 
um pouco arbitrariamente num indivíduo, o tirano potencial presumido, toda a carga, e fazia cair sobre ele todo o peso político da cidade, e exorcizava o perigo ao expulsá-lo ${ }^{35}$.

Para o autor do Ensaio sobre a mobilização política na Grécia antiga, o ostracismo era, antes de tudo, uma lei a ordenar a pólis contra o poder dos tiranos ou daqueles que intentaram romper a soberania das leis. Esboça-se, de certo modo, uma caracterização parcial do ostracismo e da própria tirania, pois se desconsidera a abrangência maior da atimia (seu papel não apenas político, mas moderador) e o alcance histórico das próprias tiranias arcaicas no prover das cidades. Assim, o tirano é tomado por sua dinâmica essencialmente negativa, ou a de exasperar as tensões políticas. Sob esse aspecto, ao pôr em relevo apenas a gênese tensiva da lei, Trabulsi não enfatiza que coube ao tirano arcaico impor a medida em momento adverso e de transição, no qual o uso da força e, por extensão, da medida garantiram a possibilidade de desenvolvimento das cidades-estado, da afirmação do demos contra a velha aristocracia, abrindo caminho para o nascimento da democracia. Se assim o é, o tirano arcaico era objetivamente figura contraditória, positiva e negativa, mas determinante e fecunda para os destinos da pólis clássica, como já firmado.

Então, é justo considerar a lei do ostracismo como uma regulação da pólis e não apenas como instrumento a atingir a figura do tirano: o ostracismo defendia a comunidade, seus valores e sua ordem, pois, como afirma o próprio Trabulsi, parte importante da cidade se envolvia nos processos por atimia, os quais se realizavam, em certas ocasiões, enquanto um quase rito, a fim de 'exorcizar' o cidadão atingido. Deve-se marcar neste contexto argumentativo, ademais, que, ao examinar a ordem jurídica do ostracismo, Trabulsi desvela sua dimensão comunitária ao apontar que estas assembléias “jurídicas” eram formadas com o maior número de cidadãos - mínimo de seis mil, algo desconhecido a uma pauta que envolvesse outros assuntos. Tratava-se de um número elevado, mesmo para Atenas, de modo que a referência a um quorum mínimo de seis mil cidadãos reflete, sem dúvida, a importância e relevância de tais processos para a pólis, como também faz notar que eventos que mobilizavam os destinos da comunidade e de seus membros implicavam a participação maciça dos cidadãos. Segundo estimativas, o corpo cívico de cidadãos à época de Clístenes girava em torno de doze mil, o que na prática, para os casos de ostracismo, exigiria o

35. José Antonio Dabdad TRABULSI, Ensaio sobre a mobilização política na Grécia antiga, p.96. 
envolvimento e voto de metade da comunidade política, envolvimento que para Trabulsi, porém, estaria superestimado. ${ }^{36}$ De qualquer modo, o número elevado de cidadãos nos processos de ostracismo denota, a despeito de uma maior ou menor participação, a importância cívica que tais processos implicavam, porque a "exigência de participação em massa, com maiorias elevadas, era necessária para criar a idéia de que a cidade, de forma quase unânime, tomava uma decisão tão grave”. ${ }^{37}$

Trabulsi, ademais, indica dois importantes aspectos conexos acerca do ostracismo que se deve aqui ressaltar. Primeiramente, o procedimento jurídico específico das assembléias; em seguida, a data anual em que se realizavam tais encontros. Quanto à primeira questão, afirma:

\begin{abstract}
Vários aspectos distinguem a ostracoforia de uma ekklesía normal (kýria ou não) e contribuem para atribuir-lhe um caráter especial, excepcional. A reunião era presidida pelos nove arcontes e pela Boulè completa, e não, como de hábito, pelo epistate da Boulè e pelos prítanos. O ostracismo se desenrola na ágora e não na Pnyx, o que, além do caráter solene (pois a ágora era o antigo local da reunião), multiplicava a capacidade de público. Isso era necessário pois a afluência era, nessas ocasiões, excepcional. Trata-se de uma reunião que poderíamos chamar, seguindo a terminologia de Hesichius, uma kataklesía, 'reunião de população vinda do campo para a cidade quando se devia resolver uma questão mais importante que as habituais' ${ }^{38}$
\end{abstract}

De pronto, chama a atenção o fato de a ágora ser o local próprio das reuniões ostracísticas. Concretamente, a ágora representava não apenas o marco histórico da institucionalização da política, da praça enquanto lugar comum da racionalidade onde os problemas eram vividos e enfrentados, mas também o local de maior afluência e abrangência da pólis a comportar o maior número de cidadãos da cidade e do campo para decidir sobre assuntos de relevância comunitária extrema. Nesse sentido, ainda, a ágora localizava-se na parte baixa de Atenas, o que, indubitavelmente, facilitava o seu acesso. Porém, o que deve ser retido é o fato de que a ágora era, vale a expressão, a síntese da pólis, o lugar por onde todos passavam, discutiam e até mesmo comercializavam; de certa forma, era o coração comercial e político das cidades, das assembléias, dos assuntos mais

\footnotetext{
${ }^{36}$. Cf. TRABULSI, Ensaio sobre a mobilização política na Grécia antiga, p.100-4.

${ }^{37}$. Ibid., p.104.

${ }^{38}$. Ibid., p.98.
} 
caros que envolviam a tomada de posição pela maioria de seus cidadãos. Por serem realizadas na ágora, as assembléias por atimia atestavam o talhe das cidades, a cidadania ampla que ordenava e articulava o voto tanto do pequeno cidadão camponês, como do cidadão urbano, citadino, assembléias que, por sua abrangência e importância, eram presididas pela cúpula política que gerenciava os assuntos da cidade - pelos nove arcontes e a Boulè completa. Fica evidente, e isto é a que se quer uma vez mais dar relevo, a importância pública do ostracismo e de como tangia a vida citadina, importância na qual comparecia a dimensão pública da política, que testemunhava, por sua vez, a natureza medial da vida ateniense.

Quanto às datas destas reuniões, Trabulsi esclarece:

... a escolha da data era 'estratégica'/.../Observemos o calendário: sexta pritania $=28$ Posideon a 4 Antestérion; sétima pritania = 5 Antestérion a 11 Elafebólion. Estamos em pleno inverno (janeiro, fevereiro, março), época em que os trabalhos dos campos se acalmam e em que é até necessário se estar mais na cidade para vender os produtos. É também a época das festas muito populares das Lenéias (sexta pritania) e da Antestérias (sétima), festividades essenciais do ciclo dionisíaco. O dia da ostracoforia podia assim ser fixado num momento em que a afuência poderia ser máxima; em todo caso, num dia em que um movimento inabitualmente forte na ágora desse a impressão de que toda a cidade estava lá. ${ }^{39}$

Além do local, portanto, a data das reuniões possuía e revelava nítida dimensão comunitária, porque capaz de assegurar a presença de inúmeros cidadãos: seja por ser tempo de venda, seja por ser tempo de festa. Época, então, propícia à pratica do ostracismo, uma vez que atividade socialmente central e, enquanto tal, demandante da presença efetiva dos cidadãos. De sorte que a esfera jurídico-política era eminentemente coletiva, orgânica que apontava para a democracia da pólis, democracia que, pelo exposto, era antes necessidade real do que abstrato fruto cultural.

Esboçado este quadro, necessário adensá-lo com as observações do livro III [1283 b] de Política, que, diferentemente da $C A$ (onde são relatados a origem e os principais personagens ostracizados) traça uma análise que permite desdobramentos mais específicos do ostracismo. A exemplo:

39. José Antonio Dabdad TRABULSI, Ensaio sobre a mobilização política na Grécia antiga, p.97-8. 
Porém, se há um indivíduo - ou mais de um, mas não o suficiente para constituir o efetivo inteiro de uma cidade - cuja superioridade de virtude seja tal que nem a virtude, nem a capacidade política de todos os outros possa se comparar às suas /.../se ele é um único, tais homens não devem mais ser tratados como uma simples fração da cidade; causar-lhes-á prejuízo ao se lhes reconhecerem somente direitos iguais, tanto sua virtude e sua capacidade política os tornam desiguais: é natural que um tal indivíduo seja como um deus dentre os homens. Donde se vê que a legislação também concerne necessariamente aos homens iguais, ao mesmo tempo pelo nascimento e pela capacidade, enquanto que contra esses seres superiores não há lei: eles mesmos são a lei. Na verdade, seria ridículo tentar legiferar contra eles: eles diriam sem dúvida que, segundo Antístenes, os leões responderiam às lebres que reivindicavam em assembléia a igualdade para todos. ${ }^{40}$

Não obstante a ênfase excessiva com que Aristóteles destaca determinadas qualidades de alguns homens, suas palavras revelam o medo e os problemas que, in communitas, adviriam da convivência destes indivíduos com os demais cidadãos, donde se escava o fundamento destas ponderações, a saber: de que modo a cidade poderia lidar com homens moralmente e politicamente superiores ou desiguais aos demais, homens que sintetizavam o que de melhor existia em termos éticos e humanos? Em outros termos, sendo a própria medida, a lei viva, tais homens alterariam a isonomia e o equilíbrio citadinos: suas melhores qualidades romperiam o metro, os pilares da pólis ateniense, a igualdade entre livres e iguais. De tal modo que tais indivíduos seriam deuses entre os homens. O que se observa é que o alerta aristotélico se faz na direção de que estas individualidades seriam incapazes de se pôr e de conviver no mesmo nível jurídico-político dos demais. Como acatar a lei se a própria individualidade é a encarnação da lei? A imposição da mesma, nestes casos, só podia acarretar enorme injustiça, logo, desequilíbrio societário. E por tal reflexão, que ora se complementa, o estagirita adensa e amplia a questão sobre o ostracismo, indicando que sua origem se vincula a este latente desequilíbrio entre cidadãos [Política, III, 1284 a]:

... isso explica também que as cidades democráticas instituam o ostracismo por uma razão desse gênero: esses Estados, com efeito, parecem buscar a igualdade antes de qualquer outra coisa; em conseqüência, as pessoas que parecem ter muita influência por causa de sua riqueza, ou do número

40. ARISTOTE, Politique, p.83-4. 
de suas relações, ou de toda outra forma de poder político, aplicar-se-ia a elas o ostracismo e elas seriam banidas da cidade por um período determinado. ${ }^{41}$

Aristóteles demarca precisamente o que levou à imposição do ostracismo nas cidades democráticas: numa palavra, a busca da medida, do metro entre cidadãos. Isto é, e vale reiterar, o que estava em jogo não era apenas a ascensão possível de um tirano a desequilibrar politicamente as cidades, mas o ostracismo era a mediação político-jurídica da isonomia, da igualdade entre cidadãos no âmbito político, das magistraturas, da ética, etc.; portanto, a preservação da igualdade entre os iguais. Assim, o ostracismo se justapunha ao metro, que se impunha como força mediana a marcar e reger os destinos da pólis. Qualquer indivíduo, não apenas no âmbito político, mas no que concernia às riquezas e relações, não deveria se sobrepor aos demais sob pena de infringir a medida, a eqüidade que possibilitaria a vida. Então, ao se ostracizar alguém, ostracizava-se aquele que, em vários domínios, superara-se face aos demais cidadãos, seja positivamente (o homem ético-político referido por Aristóteles), seja negativamente, o tirano, que se impunha pelo uso da força contra a comunidade. De qualquer modo, positiva ou negativamente, o homem que rompia a medida, a igualdade entre cidadãos, firma Aristóteles, abalava o fio social que sustentava a soberania do nomos, a referência à lei que articulava e possibilitava a instauração da justiça ou algo próximo. Quando a lei não era mais critério, a comunidade perdia os parâmetros, orfanava-se a si mesma. Aristóteles assinala, corroborando a argumentação, o solo propulsor que moveu tais processos [Política, III, 1284 a]: "Essa prática não beneficia apenas os tiranos e os tiranos não são os únicos a recorrer a ela; nós a encontramos, igualmente, nas oligarquias e nas democracias: o ostracismo tem, de uma certa maneira, o mesmo efeito de cercear os cidadãos que ultrapassam os outros e de os exilar" ${ }^{42}$ Ao expor os motivos pelos quais alguém poderia ser ostracizado, Aristóteles deixa claro que qualquer atributo, positivo ou não, que atentasse contra o equilíbrio entre cidadãos, poderia conter as premissas necessárias à realização do ostracismo. Note-se que o filósofo não se atém ao universo do tirano; antes, todo e qualquer cidadão estaria exposto a um processo por atimia, posto que alguma ação, qualidade ou falta ultrapassasse o espaço da boa convivência,

\footnotetext{
${ }^{41}$. ARISTOTE, Politique, p. 84.

42. Ibid., p. $84-5$.
} 
interferisse na igualdade e harmonia citadinas. O ostracismo, portanto, é um expediente jurídico no sentido de estabilizar a pólis, de mantê-la em ordem e simetria societárias. Ao mesmo tempo, e assim Aristóteles pontua uma dimensão ainda não aludida, refere que o ostracismo impôs e garantiu, de certa forma, o equilíbrio regional entre as cidades. Significa que a atimia impediu, por vezes, o surgimento de contrastes e de lideranças que, mesmo em sua forma incipiente, poderiam se opor à liderança político-militar que Atenas exerceu no mundo antigo. O equilíbrio das cidades e o equilíbrio regional se potencializavam na direção da mitigação das rivalidades, nascidos de uma orgânica política que então se voltava à coesão possível da comunidade. Trabulsi afirma o seguinte, com o que se desdobra o argumento: “Outra vez mais, é o medo da stasis e de suas conseqüências, a busca do bom entendimento cívico, esta busca sem fim que atravessa a história da cidade grega, que ilumina a instituição do ostracismo”. ${ }^{43}$ A stasis prefigurava, ao menos em potência, a possibilidade do desequilíbrio comunitário, da luta fratricida entre famílias e cidades, numa palavra, da perda da medida, do metro que referenciava a 'busca do bom entendimento', a vida in communitas do homem político. Retomando, a propósito, uma formulação de Wolff, que bem indica a aversão grega pelo desequilíbrio, pela stasis, tem-se que em

\begin{abstract}
Atenas, no século V, desconfia-se das especulações teóricas dos 'filósofos' sobre a Natureza e sobre o Ser, e o primeiro filósofo da cidade, Sócrates, foi condenado por ela à morte. Tudo se passa como se, na idade clássica da cidade, as exigências da política se opusessem às da filosofia. A preservação da cidade não requer outra especulação além dos velhos princípios de uma moral pragmática, e, por conseguinte, proíbe a do 'livre-pensador', o filósofo: pensar demais, os deuses da cidade o proíbem; pensar bem demais é uma ameaça para o equilíbrio entre cidadãos (veja-se a instituição do 'ostracismo'); pensar diferente demais, é uma ameaça para a harmonia da cidade (vejam-se os numerosos processos ‘antiintelectuais’ do século V). ${ }^{44}$
\end{abstract}

Wolff indica, pois, não apenas a natureza de diversos processos antiintelectuais que redundaram na perseguição e morte de alguns pensadores, notadamente Sócrates, mas, a partir daí, entremostra a natureza do próprio ostracismo. Atina-se que os processos por

\footnotetext{
43. José Antonio Dabdad TRABULSI, Ensaio sobre a mobilização política na Grécia antiga, p.113.

44. Francis WOLFF, Aristóteles e a política, p.15.
} 
ostracismo não buscavam apenas conter a emergência potencial da tirania, mas, em sentido amplo, defender a equanimidade entre cidadãos, a harmonia citadina, a medida que organizava e vivificava a sociabilidade grega. Suas palavras, assim, corroboram, lato sensu, a determinação do ostracismo como norma jurídica a atenuar diferenças, impondo o metro ao exilar o cidadão. Cite-se, para concluir, as palavras do próprio Aristóteles [Política, III, 1824 a e b] que reafirmam o caráter mediano do ostracismo nos mais diversos regimes:

O problema, de um modo geral, se coloca para todas as formas de governo, mesmo para as formas corretas; as constituições desviadas, no único cuidado de seu interesse particular, adotam essa prática, mas os regimes sociais do bem comum não agem muito menos da mesma maneira. As artes e as ciências em geral fornecem uma prova evidente disso: um pintor não deixaria seu personagem com um pé, fosse ele particularmente belo, que ultrapassaria a justa proporção; um construtor de navio não toleraria uma popa ou toda outra parte do navio fora de proporção; um mestre do coro não admitiria muito menos que fizesse parte do coro um corista que tivesse uma voz mais forte e mais bela que todo o coro. De acordo com essa regra, nada impede, então, os monarcas de estarem em pleno acordo com suas cidades, sob a condição de não recorrer a essa prática senão quando seu próprio poder serve ao interesse de sua cidade. Assim, quando se trata de superioridades reconhecidas, a argumentação a favor do ostracismo tem uma certa justificação política. Seria preferível, certamente, que o legislador tivesse constituído, desde a origem, o regime de maneira a não ter necessidade de um tal remédio; mas uma segunda manobra, útil na ocasião, é de tentar, por um corretivo desse gênero, corrigir o regime. Mas isso não é o que se produzia com efeito nas cidades: em lugar de considerar o interesse de seu próprio regime, é com um espírito partidário que elas recorriam às medidas de ostracismo. ${ }^{45}$

Nesta passagem expressiva, o estagirita, saliente-se, expõe a razão de ser do ostracismo: mediação para equilibrar os regimes políticos, para encontrar a proporção, a eqüidade, tal como procediam os pintores, os construtores e os regentes. O ostracismo era o forjamento do ponto médio que permitia a simetria, o metro que devia possibilitar o equilíbrio social próprio das funções estéticas e mecânicas. Que o ponto médio devia ser um télos social nos mostram as artes, cuja beleza e efeito humano positivo estão, e não secundariamente, em sua inclinação ao termo médio; artes, então, que deviam referenciar a vida pública e privada. Em termos concretos, da pintura e da música emanam as simetrias pictóricas e melódicas; o pintor não pode consentir a desproporção em seu desenho ou

${ }^{45}$. ARISTOTE, op. cit., p. 85-6. 
pintura, antes, deve pintar de forma e maneira que a obra ganhe proporção por igual, limites nítidos e vigor expositivo; a simetria de suas partes deve proporcionar ao expectador um efeito estético global de unidade e equilíbrio. Quanto ao regente de um coro, este deve cuidar que as vozes ganhem equilibrada densidade, sonoridade proporcional de tal modo que o coro compareça harmonicamente em seu todo, e as partes, em sua interação, apresentem-se na fluência de um timbre que permita a suavidade e o vigor da melodia. Nenhuma voz deve se sobrepor à outra, pois o efeito estético é desarmônico, impreciso, de efeito duvidoso. Igualmente, o construtor deve zelar pela proporção e simetria das partes que compõem um navio, pois suas funções dependem diretamente da unidade e ordem implícitas em seu desenho e estrutura; um navio em que as partes não sejam estritamente simétricas, é incapaz de navegar, de exercer suas funções concretamente. Se assim o é, o estagirita entendia o ostracismo - o termo médio político - como mecanismo legítimo a equilibrar os regimes políticos, tanto os corretos, como os desviados, e deste modo, por uma simetria interna conquistada, cada regime preservava-se, esboça Aristóteles. Em tal contexto, o ostracismo era plenamente legítimo se fosse empregado para garantir a ordem política, a soberania dos regimes, pois como o filósofo alude, é mais fácil exilar alguém (se isto beneficiar o regime) do que mudar o regime. Por isso, diante da fragilidade das cidades-estado o ostracismo foi, sem dúvida, mecanismo a impor limites de convívio, a engendrar tolerância onde se instalariam lutas dramáticas. Limites que, buscando um ponto médio que se devia imitar das artes, significou vida medial, justo termo eqüidistante. 


\section{CAPÍTULO III}

\section{É T I CA, LIMITE E MEDIDA}

Neste capítulo, o objetivo de fundo é indicar como a ética, em mãos aristotélicas, muda substancialmente de figura ${ }^{1}$. Mutação que significou o reconhecimento do papel mais ativo do indivíduo, que agora se afigura subjetivamente mais apto e capaz de ordenar, escolher e deliberar a partir das significativas relações com a comunidade e de suas influências. Assim, a afamada propensão aristotélica pela medida é, sem dúvida, advinda do reconhecimento de urgências citadinas, quer dizer: o comportamento ético da justa medida é o reconhecimento - no plano individual - de que o indivíduo deve impor limites aos seus desejos e apetites, como também moderar-se face à riqueza e a tudo que, de modo expressivo, possa interferir na ordem e no bom andamento comunitários. Ética que assim armada confirma, por mais esta via, o suposto deste estudo. Vejamos, então.

\section{A ética enquanto relação entre indivíduo e comunidade.}

A originalidade da Ética Nicomaquéia (EN) reside em examinar as ações humanas não apenas no pólo do indivíduo e de sua ação, mas em suas possíveis e desejáveis conexões com a comunidade. A práxis humana, assim, é analisada a partir das ações efetivas, reais e suas considerações são postas a partir de tais percepções. Conseqüentemente, encontramos no texto colocações profanas, racionalidade observacional que, de forma inovadora, reordena o exame moral que, antes compreendido no sujeito, é agora compreendido na polaridade indivíduo/circunstâncias. Há, portanto, uma opção consciente pela imanência dos fatos observados, o que explica a recusa aristotélica em estabelecer padrões comportamentais de caráter a priori. Feitio analítico que transforma a EN em obra singular

\footnotetext{
1. Destaque-se, em primeiro plano, as diferenças substanciais entre a ética nicomaquéia e a ética platônica. Decerto, o estagirita configura um novo patamar para a reflexão ética que se descola e distancia, a partir de sua vocação à objetividade, da ética platônica. Assim, a EN não encontra (como em Platão), na ascese intelectual, a via da ação eticamente viável.
} 
na história do pensamento ético. A análise do estagirita, pois, compreende as ações no eixo indivíduo/comunidade. Nesse sentido, os atos implicam ou se desdobram para além do indivíduo, imprimindo conseqüências à comunidade. $\mathrm{O}$ ineditismo do autor da $E N$ se realiza na condição de compreender as ações no interior das cidades-estado, ou seja, na unidade homem/cidade que faculta, possibilita e influencia o agir dos homens. Assim, em EN [I, 1099 b] este argumento se desvela ao reconhecer que:

... impossível ou, pelo menos, difícil de fazer o bem quando se está desprovido de recursos. Pois certos atos exigem, como meio de execução, amigos, dinheiro, um certo poder político. Na falta desses meios, a felicidade da existência se encontra alterada, por exemplo, se não se goza de um bom nascimento, de uma descendência feliz e de beleza. Não se saberia, com efeito, ser perfeitamente feliz, quando se é desgraçado pela natureza, de nascimento obscuro, solitário na vida ou desprovido de filhos; menos ainda, talvez, se tem filhos e amigos completamente maus ou se, depois de tê-los tido bons, perdê-los. Como dissemos, a felicidade, segundo a opinião comum, exige semelhante prosperidade. Eis a razão segundo a qual alguns colocam no mesmo grau da felicidade a prosperidade, assim como outros a virtude. ${ }^{2}$

A percepção é notável e se deve destacar que o ato moral depende, de maneira especial, das condições de inserção do indivíduo nos meios da sociabilidade: familiares, poder, ser bem nascido, condições tais que o atam, visceralmente, à própria comunidade. De fato, uma vez mais, é assinalada a relação entre indivíduo e comunidade quando se trata de ação. Assim, a individualidade, que por natureza ou acidente, não se ate à família ou amigos está, sem dúvida, limitada ou constrangida em suas perspectivas. Note-se que a ação moral é movimento no qual o enlace com a comunidade é decisivo, pois encontram-se na fratria as possibilidades de sua realização. Deste modo, os atos humanos são inseridos na unidade e no encontro compreendido entre as faculdades, as pretensões individuais e as possibilidades concretas de sua efetivação, ou seja, a unidade entre o indivíduo, suas capacidades e o universo incerto e contingente da vida citadina. Emerge em EN [II, 1107 a] um discurso que inclui a observação da realidade, e é mister demarcar o evidente contraste com relação a Platão:

\footnotetext{
2. ARISTOTE, Éthique de Nicomaque, p. 36-7.
} 
Ora, não é preciso se contentar com essa afirmação geral sobre a virtude; é preciso também que nossa teoria esteja em harmonia com os casos particulares. Com efeito, no que concerne às ações, quem raciocina em geral raciocina no vazio, enquanto que, sobre os casos particulares, tem-se a chance de obter mais de verdade. Pois as ações só trazem casos particulares, elas devem então se harmonizar com essas últimas. ${ }^{3}$

Aristóteles inverte o eixo reflexivo sobre o qual se assentava a reflexão sobre a ética, vale dizer, de uma ética que regrava na abstração de comportamentos universalmente aplicados ${ }^{4}$, passa-se ao universo prático, pois a individualidade, ou aquele a que a ética se destina, atua no particular, nas circunstâncias, no possível, e é aqui que Aristóteles entende colher e desvendar os motivos internos e externos das ações. Em proposição que enuncia a dimensão de objetividade do pensamento aristotélico:

... o bem era uma idéia transcendente, concebendo-se como absoluto; contendo em si um caráter de medida perfeita e absoluta. Neste sentido era absoluto o ‘bem’ de Platão./.../Em Aristóteles, o bem, na medida em que envolve relação humana, deve abandonar seu caráter absoluto/.../os homens que lhe servem de suporte, não são de modo algum absolutos; os homens são distintos, têm objetivos e aspirações diferentes e se situam em níveis heterogêneos /.../Ao rechaçar a idéia de absoluto, o filósofo teve que considerar a heterogeneidade e a infinita riqueza das relações humanas. ${ }^{5}$

O agir é reconhecido em sua lógica própria, concreta, por isso vivificado. Heller acentua o antiplatonismo aristotélico uma vez que a ação é inserida nos meandros da pólis grega: na vida mundana de homens reais heterogêneos e imperfeitos, de indivíduos capazes ou não de realizar o bem exeqüível, relativo e atado aos interesses da cidade-estado, a termo que Aristóteles recusa o homem puramente moral do qual fala Sócrates. Observe-se a passagem abaixo, de teor emblemático, inscrito no livro VII, [1145 b], de EN:

Sócrates combatia a idéia de que se pudesse mostrar-se cientemente intemperado, como se a falta de domínio de si não existisse. Ele afirmava que ninguém, com uma concepção justa, não pudesse agir

\footnotetext{
3 . ARISTOTE, Éthique de Nicomaque, p.63.

4. Para Platão a ascese que encontrava a idéia de Bem comportava um universo ético abstrato e genérico, explicando: a idéia de Bem era reguladora, descolada da realidade prática dos indivíduos conquanto a ética se expressava em móbiles universais. Em Aristóteles, a $E N$ nasce da interação indivíduo-comunidade, estabelecendo-a a partir de situações particulares, concretas. ( Cf. EN, II, 1107 a)

5. Ágnes HELLER, Aristóteles y el mundo antiguo, p.203.
} 
senão de uma maneira excelente; no caso contrário, isso só poderia se dar por ignorância. Essa afirmação contradiz os fatos que saltam aos olhos. ${ }^{6}$

Assim, os fatos observados orientam a reflexão aristotélica rumo ao entendimento de que a ação moral não dependia apenas das suas virtudes subjetivas dos indivíduos, como se estas fossem independentes e desconexas do mundo real; diversamente, o indivíduo era reconhecido como ser em atividade influente e influenciável na vida citadina. Ao contrário do mote socrático que restringia a ética ao campo do saber, da ascese pessoal, Aristóteles atinava com os limites de uma ética centrada no sujeito, nas faculdades cognitivas, pois esta advinha de situações concretas. Conhecer a situação não implicava, in limine, como imaginava Sócrates, identificar a reta ação moral: existiam inúmeras variáveis, aludidas pelo estagirita, que comportavam possibilidades ou contraposições às ações. De fato, tomar conhecimento do que deveria ser feito não garantia o sucesso da ação e muito menos sua adequação aos fins éticos propostos. Em verdade, a ética socrática era de talhe individual, ou melhor, o indivíduo decidia sobre si, mas a partir de um desvelamento de si mesmo, no qual a decisão, pois, era o cumprimento (ou não) de algo que lhe parecesse verdadeiro. Vale dizer, aos homens era sobreposta uma orgânica de conhecimento que os encaminhava a um modo de agir correto. Não obstante, a reta razão, em si mesma, não garantia que um homem fosse temperante, pois, postos contextos humano-individuais diversos, a escolha e a deliberação eram necessariamente mediadas na e pela realidade contingente da vida citadina, como entendia Aristóteles. Então, indivíduo e comunidade, no plano ético, deixavam de contextualizar pólos isolados; no giro aristotélico, implica, precisamente, pensar esta relação (anteriormente nem mesmo pensada como relação).

No todo ou na parte, as reflexões éticas anteriores padeciam pela inobservância em relação ao solo social do qual emergiam, isto é, as ações não eram examinadas na relação com as circunstâncias. As reflexões éticas, de um modo geral, jamais se perguntaram sobre as possibilidades do agir ético: nunca questionaram a relação existente entre as normas e a possibilidade real de sua realização. Assim sendo, continham um foco essencialmente universal, abstrato, o que significa dizer que conviviam de modo assimétrico, distanciando norma ou postulado da vida real. Deste modo, o indivíduo era posto na condição de agente ético sem que se atentasse para o fato da possibilidade ou não da realização de tais preceitos,

${ }^{6}$. ARISTOTE, Éthique de Nicomaque, p.195. 
pois estes passavam pelo concreto. Nascia, sem dúvida, um enorme vácuo pelo qual a dimensão especulativa da razão se punha a ordenar normas inverossímeis, de apoucada efetividade. Então as reflexões éticas, de modo geral, se formulavam na não atenção da lógica do tecido social, isto é, não reconheciam as necessidades éticas objetivas, urdidas na relação indivíduo-gênero, que geravam estes ou aqueles comportamentos e valores. De certo modo, Vergnières, em Ética e Política em Aristóteles, alude ao problema, ainda que não o desdobre, ao observar que a filosofia, notadamente a platônica, ao se inserir no campo estritamente contemplativo promovia um distanciamento entre a ética e sua realização efetiva:

A filosofia se desenvolve/.../no campo da especulação e da contemplação. Busca no conhecimento do Bem, pela inteligência, uma norma absoluta da ação, que transcende as leis de todas as cidades. Contudo, a filosofia não pode fazer total abstração da cidade concreta, posto que os homens ordinários têm necessidade de leis críveis para guiar sua conduta. É por isso que, principalmente em Platão, se cava um fosso entre os princípios que valem no domínio da especulação e os que devem ser observados por todos no quadro da cidade. Aristóteles procurará transpor esse fosso, refletindo mais precisamente sobre a especificidade da ação e da prática. ${ }^{7}$

É certo que Aristóteles não podia entrever todas as condições humano-sociais, por ser um homem que se descobriu em sua própria história; contudo, contrariamente ao teor universal que predominou nas éticas pregressas, sua reflexão buscou encontrar as conexões entre a ação e suas possibilidades efetivas, chave para um pensamento ético verossímil. Dessa maneira a recusa de uma ética dos universais impelia e deslocava o homem para desafios superiores nos quais a definição de certo e de errado se fazia mais complexa e multíplice, postos os desafios da relação indivíduo-comunidade. Vale dizer: “O homem aristotélico já não é, por conseguinte, um homem moral em estado puro, o homem da moralidade, mas o homem concreto que na diversidade de seus atos realiza ora o bem, ora o mal”. ${ }^{8}$ Portanto, “O objeto da ética aristotélica não é o herói, não é a encarnação de tal ou

7. Solange VERGNIÈRES, Ética e política em Aristóteles - physis, ethos, nomos, p.71.

${ }^{8}$. Ágnes HELLER, Aristóteles y el mundo antiguo, p.208. 
qual virtude, ‘o homem valente’ ou o 'homem sábio', mas o homem em toda a sua complexidade, em sua diversidade de aspirações, de suas virtudes e de seus vícios”. 9 Em conseqüência, não existe nenhuma idealização da prática humana, como também nenhuma pré-condição à sua realização; firma-se, inversamente, que apenas o exercício moral efetivo do indivíduo pode conduzir à boa ação moral. Nas palavras da EN, [II, 1103 b]:

É pela prática da cítara que se formam os bons e os maus músicos. O mesmo vale para os arquitetos e os outros especialistas. Por força de se construir bem ou mal, alguém se torna bom ou mau arquiteto. Se não fosse assim, não se teria necessidade em absoluto de lições de um mestre e alguém seria bom ou mau especialista de nascimento. O mesmo ocorre com as virtudes. É por nossas maneiras de observar as ações com nossos semelhantes que nós nos tornamos alguns justos, outros, injustos. ${ }^{10}$

Aristóteles, pois, firma claramente a natureza concreta de sua ética: era a prática que viabilizava um norte às ações e suas possibilidades. Destarte, o estagirita constituiu uma ética da ação na qual o indivíduo atuava a partir de necessidades, influências da comunidade e não por qualquer determinismo ou norma. Por isso contrapõe-se, uma vez mais, ao universalismo platônico e correlatos, pois os valores passavam a ser vistos como possibilidade, isto é, nada garantia que a validade dos mesmos fosse sempre reconhecida: a escolha e a deliberação compareciam como momentos vitais de um indivíduo específico em situação ativa específica, os valores da ação só se faziam avaliáveis no caso concreto. Em outras palavras, e ampliando a argumentação, o estagirita reconhecia o indivíduo enquanto força real, concreta, na pólis, o que significava reconhecer sua interação com a comunidade, que era o pólo cujo interesse maior devia prevalecer. Então, o problema ético ganhava forma em terreno subjetivo, ou seja, a individualidade passava a ser efetivamente relevante - mas sempre tendo em vista os valores maiores da vida em comunidade - nos atos humanos e não meramente individual, enquanto seguidora de preceitos abstratos regrantes. Toda e qualquer ética normativa pré-aristotélica pressupunha uma subjetividade mais passiva, pois a norma a priori - dizia ao indivíduo o que fazer e como fazer. O caminho já estava lançado ou, no 
mínimo, substantivamente configurado. O papel da subjetividade, nestes casos, era essencialmente menor, cabendo-lhe seguir a norma, subsumir-se a ela. No caso aristotélico, reitere-se, a situação era outra, pois o tempo é outro. Ao reconhecer o lado ativo da subjetividade no livro III da EN [1111 b], Aristóteles afirma:

A escolha não tem nada em comum com os seres desprovidos de razão, capazes, porém, de desejo e de movimentos do coração. Com efeito, quem não é senhor de si é capaz de desejar, não de agir por livre escolha; em contrapartida, quem é senhor de si age por escolha deliberada e não sob impulso do desejo. Além disso, o desejo se opõe aos cálculos da escolha, enquanto que um desejo não se opõe a um desejo. O desejo se liga ao prazer e ao sofrimento: a escolha não depende nem do sofrimento nem do que é agradável. A escolha é ainda menos um impulso do coração, porque os atos provenientes do coração, visivelmente, não são inspirados por essa escolha raciocinada. Não é muito menos um ato de vontade, ainda que se pareça fortemente relacionada com ele. Com efeito, a escolha não visa ao impossível e dizer que este é objeto de uma escolha seria pura insanidade. Pode-se querer o impossível, como jamais morrer. ${ }^{11}$

A subjetividade aristotélica era tomada, pois, de modo distinto, em contornos inovadores. Sinal real é o fato de que Aristóteles repousava sobre o indivíduo a opção do caminho que iria constituir do ponto de vista ético. Nesse sentido, e de saída, estabelecia a unidade entre escolha e razão: toda escolha implicava uma dada racionalidade, motivo pelo qual os animais irracionais não escolhem. Envolvia a razão porque o ato de escolher subentendia reconhecer aquilo que era racional fazer. Significa que a escolha não se pautava pela mera vontade, desejos ou emoções momentâneas advindas de impulsos irrefletidos. Posta está, pois, uma subjetividade ativa, capaz de escolha, no caso, dos caminhos mais favoráveis ao exercício do ato moral, ético, que era a opção dos meios pelos quais o indivíduo se consubstanciava na prática de atos responsáveis, amadurecidos pela experiência e limitados por sua própria razão e tino. Com outras palavras, Marcelo Perine, em ensaio intitulado Quatro Lições sobre a Ética de Aristóteles, assim dispõe:

Aristóteles mostra que na ação moral há três elementos determinantes: a sensação, o intelecto $e o$ desejo/.../Contudo, a sensação não é princípio, e o intelecto sozinho não move a ação. O princípio ou causa da ação é a decisão (proairesis), que inclui desejo de um fim e cálculo de meios adequados para alcançá-lo. Dito de outro modo, o princípio ou causa da decisão é obra de um intelecto desejante

11. ARISTOTE, Éthique de Nicomaque, p. 78. 
(orektikos nous) unido a um desejo refletido (orexis dianoetike), e essa complexidade é, justamente, o homem. ${ }^{12}$

Perine evidencia a importância e o papel da razão, do elemento pessoal, que decide e encontra os meios adequados à ação. Não obstante, frisa de modo excessivo o papel do intelecto no movimento de encontrar a reta medida para agir, ou melhor, não aponta em termos mais decisivos a conexão indivíduo-comunidade que aristotelicamente animava e constituía a ação ética. Em outros termos, Perine acaba por confluir para a importância abstrata que concede à razão, e assim ganha corpo desmedido a primazia do indivíduo, que parece isolado da comunidade, de sorte que a sabedoria prática, ou a phronesis, é excessivamente determinante para o autor aludido. É fato que Perine compreende a importância do intelecto para a ação ética, mas dá a ele proporção desmedida. Ao acentuar, em demasia, o papel da phronesis, o autor de Quatro lições sobre a ética de Aristóteles sublinha o papel da subjetividade isolada do intercâmbio que a anima, ou seja, das situações concretas que oferecem ao indivíduo estímulo, reconhecimento e experiência para agir a partir de móveis objetivos, situados circunstancialmente na vida citadina. Assim, ao privilegiar o pólo do sujeito, Perine afirma:

A decisão racional é o ponto de junção entre a faculdade de discernimento, que inclui a imaginação, a sensação e o intelecto, e a faculdade apetitiva, que inclui o querer, a paixão e o desejo. Todo o problema da antropologia de Aristóteles se resume no problema das relações da parte pensante do homem com o apetite. A decisão racional, ao estabelecer o equilíbrio ou a justa medida entre as partes da alma, cria as condições para que o homem seja exatamente aquilo que o define como homem, a saber, o fato de ser o princípio das suas ações. ${ }^{13}$

Decerto, este não é um estudo para desenvolvermos o problema da phronesis, mas é preciso pontuar que a sabedoria prática se articulava e tomava arrimo nos interstícios das relações in communitas. Perine, de modo inverso, acaba por privilegiar abstratamente o indivíduo e as faculdades subjetivas que se fariam capazes por si mesmas em suas articulações hierárquicas de regular a justa medida. Falta-lhe, portanto, a vida citadina que condicionava e permitia que os apetites, os desejos e a racionalidade se tornassem plenos em sua potência. Ao destacar o papel ético do indivíduo, Perine arremata:

${ }_{13}^{12}$ Marcelo PERINE, Quatro lições sobre a ética de Aristóteles, p.23.

13. Ibid., p. 68-9. 
O primeiro ponto a ser destacado consiste no caráter normativo da reta regra. Em 1138 b23 e b34 encontramos as únicas ocorrências do substantivo norma (horos) na Ética a Nicômaco dado que 1153 b24-25, onde ele também ocorre, pertence à Ética a Eudemo, segundo a unanimidade dos especialistas. A observação é decisiva porque da natureza da regra depende a compreensão da phronesis como virtude, uma vez que o conceito de norma, expresso pela forma passiva do verbo orizein, é central na própria definição da virtude (cf. 1106 b36 -1107 a1). Aristóteles diz claramente que o justo meio consiste em agir conforme ordena a reta regra (1138 b19-20), e o verbo legein que aparece nessa passagem deve ser traduzido, como o fiz aqui, no sentido de ordenar, comandar (keleuo), pois só assim faz sentido a afirmação de que existe uma norma dos estados que se mantêm no justo meio (1138 b23). Ora, se a reta regra determina o justo meio e é obra da phronesis, como dirá Aristóteles, então é forçoso concluir que no conceito de phronesis há uma dimensão imperativa que introduz na ética aristotélica a idéia de dever. ${ }^{14}$

Que a phronesis é decisiva no efetivo ato moral não há dúvida. O que me parece precipitado é a conclusão do autor de que a phronesis implica necessariamente uma dimensão imperativa e de dever. Isto porque o ineditismo da $E N$ põe-se no rompimento (em grande medida) com qualquer dimensão imperativa, pois o dever caracteriza uma subjetividade fortemente passiva, descolada da comunidade e herdeira de desígnios com os quais ainda é incapaz de lidar. Em outros termos, Perine substantiva em demasia o papel da phronesis, deslocando abstratamente a ética aristotélica para o pólo do indivíduo, de suas decisões isoladas, conquanto parece que, inversamente, a ética aristotélica se desloca do pólo individual abstrato para o contexto medial em que homens e circunstâncias interagem infinitamente: o homem age, individualmente, mas a partir e em função do solo comunitário. Assim, a norma, a reta razão a ser seguida pelo homem de sabedoria prática não implicava em imperativos e deveres, porque a norma ética (se é que isto existe em Aristóteles) era a capacidade do homem prudente de analisar, compreender e, diante de situações diversas, deliberar adequadamente, reconhecendo, pela experiência, o que era conveniente fazer. Aristóteles entendia a ação a partir de uma subjetividade ativa que se libertava, paulatinamente, das amarras normativas e dos imperativos e deveres abstrato-universais, alçando-a para um plano objetivo, de modo que soluções éticas passavam a implicar o terreno complexo da contingência, das possibilidades, do acaso e das decisões. Destarte, como assinala Vergnières - e aqui concluo este pequeníssimo espaço sobre a phronesis;

\footnotetext{
${ }^{14}$. Marcelo PERINE, Quatro lições sobre a ética de Aristóteles, p.22.
} 
assunto que se retoma, mesmo que parcialmente, quando da discussão das virtudes morais -, a contingência e o acaso passam a compreender o espaço ético, pois o

acaso pode, pois, fazer com que um homem virtuoso se ponha a cometer uma injustiça ou que um homem incontinente realize atos conforme a lei. Certas causas externas ou internas são, aliás, propícias a esse gênero de situação; todo homem conhece a experiência de descontinuidade/.../a vida humana comporta intermitências, momentos de relaxamento onde o acaso pode ter maior influência sobre o indivíduo. ${ }^{15}$

Em confluência com EN, e aqui se retoma o fluxo argumentativo central, em Ética a Eudemo [II, 1226 a], a dimensão da escolha é assim caracterizada:

No entanto, a intenção e a escolha deliberada não são idênticas. Pois se fazem certos desejos sabendose por completo que eles fazem parte do impossível, como de ser rei de todos os homens e de ser imortal, mas ninguém faz uma tal escolha deliberada sem ignorar que é impossível e, geralmente, não se escolhe algo possível mas que não nos cabe/.../Segue-se então esta evidência: o objeto da escolha depende necessariamente de nós. ${ }^{16}$

O estagirita acentua a escolha conquanto momento racional, ou seja, a escolha era a determinação dos meios factíveis, realizáveis no plano da vida cotidiana, adequados ao convívio comunitário. Deste modo, não escolhemos ou tendemos ao impossível, pois a escolha era posta na esfera real, daquilo que devia ser feito conquanto resultante em ação plena, exeqüível. A ação ética, pois, devia combinar as escolhas e as possibilidades, e o que fosse imediatamente inexeqüível constituiria apenas desejo e vontade, sonho, por vezes pueril, que nada agregava. Em outras palavras, a escolha ganhava a dimensão da objetividade, ou melhor, era a condição objetiva da individualidade que então realmente operava por si, era possibilidade real, efetivação empírica de uma ética possível do indivíduo, que assim era reconhecido de fato como tal in communitas. De sorte que o que se põe são conquistas teóricas evidentes, que individuam a ação ética porque compreende a radicação do indivíduo no interior da comunidade; assim, pensar a escolha significa não apenas refletir sobre a possibilidade pessoal de sua efetivação, mas, imediatamente, sobre o ônus comunitário que tais escolhas acarretam. Aristóteles preocupava-se com as

${ }^{15}$. Solange VERGNIÈRES, Ética e política em Aristóteles - physis, ethos, nomos, 109.

${ }^{16}$. ARISTOTE, Éthique à Eudème, p.110. 
conseqüências inevitáveis que as ações geravam, não só para o próprio indivíduo, mas decididamente para o seu semelhante, para a comunidade.

Posto tal contexto, nada a estranhar que na sua determinação ética sobre o ato de deliberar, Aristóteles o entendesse e situasse a partir da mesma natureza que a escolha [EN, III, 1112 a]:

Acontece de se deliberar sobre todos os assuntos? Tudo é objeto de deliberação? Ou bem, em alguns casos, a deliberação não intervém? Talvez, é preciso dizer que é objeto de deliberação apenas aquilo sobre que pode deliberar um homem sensato e nunca um ser estúpido e loucamente furioso? /.../ Não se delibera muito sobre os movimentos celestes que se reproduzem sempre segundo as mesmas leis; que seja preciso atribuir esse retorno regular à necessidade, à sua natureza ou a qualquer outra causa, como os equinócios. /.../ Do mesmo modo, não se delibera sobre tudo o que interessa aos homens: por exemplo, nenhum lacedemônio se atreveria a deliberar sobre as melhores instituições para os citas. Pois nada disso pode se fazer por nossa intervenção. Nós deliberamos, porém, sobre aquilo que depende de nós e pode ser efetuado por nós. ${ }^{17}$

A tese central do estagirita se arma na constatação de que, como na escolha, a deliberação dependia de pressupostos factíveis, realizáveis: não deliberamos acerca das forças da natureza assim como sobre assuntos da comunidade que não nos dizem respeito ou que não estão a nosso alcance. De fato a argumentação exposta na $E N$ retoma, lato sensu, a trama pré-existente na EE [II, 1226 a]:

Em suma, dentre as coisas que podem ser e não ser, é possível que algumas sejam objetos de deliberação; para outras, é impossível: com efeito, o que pode ser e não ser, mas cuja aparição não depende de nós, e que aparece tanto por natureza, tanto por outras causas, não será para ninguém objeto possível de deliberação, senão por ignorância; /.../ Também não deliberamos sobre os assuntos dos indianos, nem sobre a quadratura do círculo. Pois os primeiros não dependem de nós e a outra escapa totalmente à ação. Mas nós não deliberamos nem sobre todas as coisas em que depende de nós que se façam - no que está claro também que a escolha deliberada não é simplesmente a opinião mas as coisas a escolher e a fazer são coisas que dependem de nós. ${ }^{18}$

A deliberação tem o formato da razoabilidade, porquanto é compreendida, rigorosamente, no campo dos possíveis. $\mathrm{O}$ ato deliberativo compreendia sua realização, pois

17. ARISTOTE, Éthique de Nicomaque, p.80.

18. IDEM, Éthique à Eudème, p.111-2. 
deliberar sobre o impossível era mera volição inconseqüente, desprovida de sentido, de um homem ainda atado aos desígnios divinos. Dito diversamente, deliberar com racionalidade significava encontrar a dimensão sensível, isto é, o solo da pólis e de seus problemas, ou seja, fazer o que devia ser feito na medida em que se pudesse agir com objetivos claros e reconhecidamente efetivos. Ao considerar que se devia deliberar sobre coisas possíveis, Aristóteles determinava a condição profana da ética - ação que se realizava a partir do mundo, humana realidade ativa. Tal condição é expressa quando assinala em EN [II, 1103 b] que a “A presente obra não se propõe a um fim teórico, como as outras, pois nossa pesquisa não visa a determinar a natureza da virtude, mas o meio a ser empregado para se tornar virtuoso, sem o quê sua utilidade seria nula”. ${ }^{19}$ Ora, o foco aristotélico era a busca dos meios para a ação virtuosa ou ética. Significa que o forjamento de uma alma virtuosa se consubstanciava na práxis e na compreensão desta práxis, num movimento que implicava um sujeito ativo atado ao solo da ação, a comunidade. Pouca valia tinha para o indivíduo o saber teórico sobre a ética, pois, e aqui irrompe o ineditismo aristotélico, em EN deslocavase a virtude e seu saber do plano teórico para o plano real, da vida citadina, real espaço do ético, onde a individualidade enfrentava seus dilemas práticos. Em resumo, de nada valia saber o que era a virtude se não havia a escolha dos meios e a deliberação de sua prática. De modo que a preocupação de Aristóteles era, acima de tudo, a de contribuir para que o indivíduo escolhesse em sua ação a prática do bem. Insista-se, o que estava em jogo não era o conhecimento teórico sobre o bom ato moral ou a virtude, mas como viabilizar que as ações dos homens fossem éticas do ponto de vista comunitário, no sentido de prevalecer o ideal de vida comunitário. Assim, jogando no terreno concreto da comunidade, Aristóteles acaba por perceber o quão intrincado, variável e multíplice era o terreno moral, e, acima de tudo, atina que a esfera moral estava para muito além de meras expectativas, desejos, regramentos ou preparo intelectual dos indivíduos. Em verdade, ao adentrar este terreno, Aristóteles vê-se obrigado a escavar e percorrer os caminhos da pólis grega, em especial os da política, tida como instrumento maior à administração do bem comum. E deste movimento intelectual nasce sua acepção ética, na qual realizar individualmente o bem, firmá-lo in communitas, passava a ser o motivo central tanto para o indivíduo, como para a

19. ARISTOTE, Éthique de Nicomaque, p.53. 
comunidade política. Do que emerge a decisiva preocupação com os atos e sua inerente responsabilidade. Isto é, existe o esforço por identificar, dentro daquilo que os limites sociais facultariam, a presença ou ausência de responsabilidade nos atos humanos, pois, intrínsecos ao cotidiano das cidades-estado, implicavam benefícios ou malefícios à constituição e harmonia da vida citadina. Na reflexão de Vergnières sobre a importância da responsabilidade entende-se que a

afirmação da responsabilidade do homem em face a seus próprios atos vai transformar o significado e o valor atribuídos ao ethos. Na Ética a Nicômaco, Aristóteles repete que o ethos é o resultado de nossos atos: adquiri-se tal ou tal disposição ética agindo de tal ou tal maneira. Realizando coisas justas assumem-se bons hábitos e o caráter torna-se justo; inversamente, agindo de maneira intemperante, adquire-se o hábito de ceder aos desejos e tornamo-nos intemperantes. O caráter não é mais o que recebe suas determinações da natureza, da educação, da idade, da condição social; é o produto da série de atos dos quais sou o princípio. Posso pois ser declarado "autor"/.../de meu caráter, como sou de meus atos: do mesmo modo que meus atos podem ser objeto de um elogio, meu caráter pode ser objeto louvor. Vício e virtudes não são simples traços psicológicos adquiridos; têm o significado moral, porque pertencem ao campo do que depende de nós. Quando ajo, não faço somente algo de pontual pelo que terei que responder, escolho o que vou fazer ${ }^{20}$.

Vergnières, pois, reforça o argumento de que a ética aristotélica pressupunha os laços que uniam e atavam o indivíduo à comunidade conquanto afirma que a responsabilidade do ato humano, em Aristóteles, era depositada sobre o agente. Vale dizer, se estamos frente a indivíduos que agem, imediatamente estamos frente a um universo que sofre esta ação e que, necessariamente, com ela se enreda: a ação era ação que, mediata ou imediatamente, movia a comunidade, de sorte que a responsabilização individual aristotélica entremostra que a ação individual significava vida citadina, espaço do ser e de sua ação. E se assim o é, no reconhecimento da complexidade da natureza dos atos Aristóteles reconhecia e imbricava, e não poderia ser diverso, a dimensão agente do indivíduo da pólis. Em EN [III, 1110 a], salienta:

Para todas as ações que nós executamos por medo de males maiores ou em vista de um belo fim, pode-se discutir a questão de saber se elas são voluntárias ou não; tomemos por exemplo o caso de um tirano que, senhor da vida de nossos pais e de nossos filhos, nos mandasse fazer um ato vergonhoso,

${ }^{20}$. Solange VERGNIÈRES, Ética e política em Aristóteles - physis, ethos, nomos, p.105. 
acrescentando à ordem a condição de que a execução salvaria os nossos, enquanto que a recusa os levaria à morte. Esses casos não são sem analogia com aquele de um carregamento lançado ao mar no curso de uma tempestade; em geral, ninguém perde de bom grado seu carregamento; resigna-se com isso para salvar sua própria vida e a de outros, como o fazem todos aqueles sãos de espírito. Assim então, tais ações não se revestem de um caráter muito claro; no entanto, elas se parecem muito com as decisões voluntárias. Pois, no momento em que elas são executadas, elas são deliberadamente desejadas. De outra parte, o fim do ato é determinado pelas circunstâncias. Assim, é necessário precisar o grau de vontade no ato que se realiza. Em tais circunstâncias, é voluntariamente que o homem age; a causa que faz mover seus órgãos reside nele; ora, ter em si mesmo o princípio de seu atos é também ter em si a possibilidade de executá-los ou não. ${ }^{21}$

Da pena do estagirita, desponta uma ética, frise-se, cujo caráter é inter-relacional. Ao caracterizar os atos voluntários, o filósofo grego enforma a articulação entre a subjetividade que devia decidir e as circunstâncias nas quais decidia. Toda a ação voluntária se realizava no câmbio entre indivíduos e situações que os radicavam e confrontavam; a subjetividade era chamada a decidir diante de fatores muitas vezes inesperados e incertos, pois contingentes e imprevisíveis. Atente-se, uma vez mais, para a polaridade emergente da $E N$ : ética era relação, encontro e possibilidade de individualidades que atuavam na vida, assimétrica, incerta, muitas vezes imprevisível. Nesse espaço contingente, então, avultava-se a importância e o preparo da subjetividade, posto que agente na pólis. E ao se priorizar a relação indivíduo/circunstâncias, a responsabilidade moral se acentuava, porque a individualidade era chamada a decidir diante de situações nem sempre favoráveis ou mesmo de risco. E o agir voluntário era pleno, quando o agente era capaz de fazer uso de suas faculdades, quando o indivíduo conhecia as circunstâncias e era capaz de avaliar as conseqüências de seus atos. Daí a afirmação do estagirita de que em tais atos “o princípio se encontra no agente que conhece todas as circunstâncias particulares da ação”[III, 1111 a]. ${ }^{22}$. Chama também a atenção, e se deve aqui pontuar, o fato de que o mesmo argumento já existia na Ética a Eudemo [ II, 1225 b]:

Somos da opinião, em suma, de que o voluntário se opõe ao involuntário e que o conhecimento da pessoa sobre quem se age, ou da causa da ação /.../ se opõe à ignorância da pessoa sobre quem se age,

21. ARISTOTE, Éthique de Nicomaque, p.73-4.

${ }^{22}$. Ibid., p. 77. 
do instrumento e do ato ele mesmo, e essa ignorância não é acidental; mas agir na ignorância sobre o ato, o instrumento e sobre a pessoa é agir involuntariamente: o contrário é então o voluntário. ${ }^{23}$

Decerto, posta a relação entre suas éticas, o argumento da segunda se vê reforçado pelas reflexões contidas na primeira. Ao afirmar que nos atos voluntários o indivíduo era alçado à responsabilidade que o ato lhe conferia, Aristóteles presumia a ação subjetiva como capaz de lucidez orientadora, pois os atos voluntários eram aqueles em que o indivíduo conhecia as circunstâncias, ou seja, as possíveis repercussões às individualidades atingidas como também os motivos pessoais e os meios adequados ao exercício da ação. Presumia, assim, o conhecimento dos atos em sentido amplo, observando-se a perspectiva de uma subjetividade agente, não subsumida a um imperativo regrante de talhe socrático, mas que se movia sobre pernas individuais no universo da pólis, espaço fundamental e princípio da ação. Aubenque assim concebe:

De fato, em sua descrição das virtudes morais, Aristóteles sempre chama a atenção para as situações que dão ao homem a ocasião de ser corajoso, liberal, justo etc. Quando as situações não são dadas e, além disso, onde não há nenhuma possibilidade de serem dadas, não há nenhuma razão para que essas virtudes floresçam. Aristóteles extrairá, então, a conseqüência rigorosa, que devia parecer escandalosa aos platônicos e parecerá ainda mais a Plotino: os deuses não são nem justos, nem corajosos, nem liberais, nem temperantes, pois não vivem num mundo onde seja preciso assinar contratos, arrostar perigos, distribuir somas em dinheiro ou moderar desejos. Os deuses não vivem no mundo da relação, da aventura e da necessidade, e querer atribuir a esses seres o que evidentemente não lhes diz respeito, sendo o que são e vivendo onde vivem, seria conceder à virtude um valor que ela não tem. ${ }^{24}$

A idéia é clara e corrobora nossa argumentação determinativa ao aludir que os atos voluntários eram ações inseridas em situações específicas. Significa que no agir ético ou virtuoso pressuposto estava não apenas a subjetividade virtuosa que deliberava voluntariamente, mas a presença de circunstâncias que permitiam não apenas a emersão das virtudes, mas, sobretudo das condições através das quais o homem tomava decisões. Deste modo, do autor de A prudência em Aristóteles pode-se depreender que a ética aristotélica arrimava-se na relação indivíduo-comunidade, sendo que o segundo pólo seria o ideal para o

\footnotetext{
23. ARISTOTE, Éthique à Eudème, p.109.

24. P. AUBENQUE, A prudência em Aristóteles, p.108.
} 
qual a ação individual devia ser regida, por isso os deuses não eram justos ou injustos na exata medida em que não exercitavam a virtude, pois que não viviam num universo incerto e contingente, lugar real da justiça, do reto proceder, isto é, lugar da objetivação do ético, das condições que permitiam avaliar a ação humana. Um outro aspecto atado aos atos voluntários que se deve trazer à baila, e que substancia a argumentação em curso, que nesse passo encontra seu caminho de fecho, diz respeito ao vício e à virtude. Aqui, Aristóteles examina a natureza da virtude moral, assim como a de seu contrário, o vício. E, sublinhe-se de saída, igualmente toma forma a presença marcante da subjetividade na escolha e na deliberação em tais atos. Virtude e vício, nesse sentido, eram caracterizados como atos voluntários, mas sempre no interior de circunstâncias advindas do interior da pólis. Em EN [III, 1113 b] discorre o filósofo:

A virtude depende então de nós, assim como o vício. Em circunstâncias onde nós podemos agir, nós podemos também nos abster; onde nós dizemos: não, nós somos senhores também para dizer: sim. Assim, então, se a execução de uma boa ação depende de nós, dependerá também de nós de não executar um ato vergonhoso; e se nós podemos nos abster de uma boa ação, a realização de um ato vergonhoso depende ainda de nós. Se, então, a execução de atos honrosos e vergonhosos está em nosso poder, nós podemos também não cometê-los - ora, é nisso que consiste a honestidade e o vício - com toda certeza, depende de nós sermos pessoas de bem ou desonestas. ${ }^{25}$

Importante distinguir, in limine, o modo como Aristóteles concebia a virtude e o vício: ambos eram caracterizados como possibilidades, frutos de uma escolha e de um agir voluntário, no interior de circunstâncias delimitadas (naquelas em que se podia agir). Seguese, destarte, a impossibilidade de se responsabilizar simplesmente o outro, determinada regra moral, ou as circunstâncias, pois o ato praticado e suas conseqüências eram de responsabilidade do agente, que, sem dúvida, encontrava-se inserido em determinadas situações, favorecedoras ou impeditivas da ação pretendida. Atente-se para o modo como o filósofo compreendia a responsabilidade dos atos humanos: os valores eram assumidos pelo indivíduo, reconhecidos pelo indivíduo, que agia e se determinava na ação. Disso se obtém, por certo, a concepção aristotélica de que os valores morais eram qualidades adquiridas na convivência entre cidadãos, portanto, não eram atributos naturais, inatos à individualidade.

${ }^{25}$. ARISTOTE, Éthique de Nicomaque, p.84. 
Ninguém era bom ou mal por natureza; as virtudes, assim como os vícios, eram atributos adquiridos pelo exercício da vida citadina. Deste modo, a ética era ação consciente advinda de uma deliberação e de uma ação voluntária, ação posta sob a regência da individualidade que, nas diversas circunstâncias, deliberava e escolhia voluntariamente, encontrando os meios para aos fins propostos. O giro aristotélico, assim, é amplo e decisivo, pois dispunha a assunção dos atos humanos para além do cerco das divindades (Homero), bem como rompia com regras ou arquétipos (de maior ou menor racionalidade) cujos parâmetros são estanques, eticamente ineficientes, pois isolados das circunstâncias concretas vividas pelos indivíduos. Estabelece o distanciamento da tradição ética anterior a que, sublinhe-se, a Ética a Eudemo [II, 1223 a], posta a responsabilidade individual do ato moral e sua dimensão voluntária, já dera início:

Também nas ações em que o homem é o princípio e o senhor, é claro que elas podem se produzir ou não, e que está em seu poder que elas se produzam ou não, ao menos aquelas cuja existência e não existência dependem dele. Aquilo que está em seu poder que ele faça ou não tem nele mesmo a causa, e aquilo de que ele é a causa está em seu poder. Já que a virtude e o vício, e as ações que deles resultam são umas louvadas, as outras condenadas (pois se condena e louva não o que existe por necessidade, sorte ou natureza, mas aquilo de que nós somos, nós mesmos, a causa, pois aquilo que tem um outro por causa recebe desse último a condenação ou o louvor), é evidente que a virtude tanto quanto o vício têm por objeto essas ações de que o homem é ele mesmo a causa e o princípio. /.../ Em verdade, nós todos admitimos que o indivíduo é a causa de suas ações voluntárias e conforme a sua escolha deliberada, mas não das ações involuntárias; e as ações que ele efetua depois de tê-las deliberadamente escolhido, é claro que é voluntariamente que ele as executa. ${ }^{26}$

Frise-se que na Ética eudemia, Aristóteles configurava, outrossim, a virtude e o vício enquanto atos voluntários cujo poder e princípio residiam no indivíduo. Era manifesto para o filósofo que virtudes e vícios eram vias cuja deliberação e escolha se armavam nas individualidades envolvidas. A EE configura-se numa orgânica na qual o indivíduo estava presente e atuante, assumindo-se enquanto tal, de modo que as duas éticas aristotélicas se somam e os homens se movimentavam diante de situações complexas e urgentes, de forma ativa, aliados a uma vida citadina em conflito perene. Em suma, a escolha, a deliberação e o ato voluntário perfaziam qualidades de uma subjetividade que ora se fazia presente, ou, ao

26. ARISTOTE, Éthique à Eudème, p. 99. 
menos, mais presente e consciente de suas possibilidades e intenções diante de um universo em franca crise, pois os anos de 384-322 (nascimento e morte de Aristóteles) configuravam já uma pólis francamente abalada por guerras, pela desagregação política do território grego, em especial, e pela impossibilidade ateniense e espartana de assumir a liderança política do mundo helênico. Eis que a subjetividade aristotelicamente afigurada é, sem dúvida, o retrato do amadurecimento difícil e dramático da individualidade helênica. Em outros termos, Aristóteles compreendia a lógica de problemas urgentes que demandavam soluções imanentes, mais racionais, tempos em que a cidade-estado já não mais vivia seu apogeu político-militar, em que o próprio futuro era, em grande medida, uma incógnita (tome-se, por exemplo, as lutas familiares do século IV, em que políticos rivalizavam em torno do apoio ou não a Alexandre), mas no interior da qual o indivíduo, expandindo-se, alcançara determinado espaço ativo. Em tal contexto, vendo e vivendo as angústias e mutações de uma cidade-estado, não poderia ser casual que sua ética incorporasse a objetividade, as relações indivíduo-comunidade, sem o que, dada a realidade multifacetada, marcada por problemas internos e externos, de resolução difícil e de prospectiva limitada, não teria força mínima de efetivação.

A EN sofreu os influxos de um tempo em que não havia mais espaço para abstrair o indivíduo da comunidade, subsumir os atos à lógica genérica de uma razão preponderante, teórica que se descolaria completamente da orgânica social vivida, das condições efetivas para a substantificação de uma ética. Em um mundo combalido, heterogêneo e de indivíduos agentes, a reflexão ética tem de supor teor empírico, norte real, pois, do contrário, como enfrentar as adversidades se a própria individualidade é incapaz de encontrar, minimamente, equações razoáveis diante da ardileza de uma época? A ética aristotélica, de um modo ou de outro, reverberava esta situação, armada na imbricação concreta indivíduo-comunidade porque eram tempos de crise e de intervenção necessária na prospectiva citadina. Ainda esclarecendo, o indivíduo ativo do qual falava Aristóteles era, acima de tudo, o indivíduo que deliberava e escolhia racionalmente diante das necessidades e dos imperativos da pólis, ou seja: o que estava em jogo era a sobrevivência da vida citadina que impunha aos homens a necessidade da tomada de decisões exeqüíveis, racionais, em poucas palavras: deliberar e escolher voluntariamente no sentido de que o agir ético equilibrasse os interstícios de uma vida citadina caudatária de suas inviabilidades ingênitas. 


\section{A ética e sua vocação à objetividade.}

Tomemos, como início deste novo momento determinativo, uma emblemática consideração aristotélica presente no livro II de Política [1266 b e 1267 a], que focaliza a articulação e reciprocidade entre riqueza, condição moral e medida:

Mas é preciso também considerar o Estado em suas relações com todos os Estados vizinhos e estrangeiros. O regime deve, então, ser ordenado em vista do poderio militar sobre o qual esse legislador não disse nada. O mesmo vale para a propriedade: esta deve ser suficiente para fazer face não apenas às necessidades internas da cidade, mas também aos perigos exteriores. É por isso que ela não deve ser nem tão grande que os Estados vizinhos e mais poderosos a cobicem, enquanto que seus possuidores seriam incapazes de repelir os agressores, nem tão pequena que eles não possam sustentar uma guerra mesmo contra os inimigos iguais e semelhantes a eles. ${ }^{27}$

Aristóteles, de fato, conecta as pontas dos nexos que vinculavam riqueza material, valor moral e medida. Desdobrando suas explanações, as cidades precisavam encontrar patamares medianos de riquezas que lhes permitissem alcançar condições de relativa autarquia, portanto, de sobrevivência interna e externa. Para isso deviam cuidar de possuir o necessário para suprir carências e promover atividades próprias ao desenvolvimento de seus cidadãos e de sua defesa. Não obstante, a cidade-estado devia evitar o excesso de riquezas, pois isto atraía a cobiça alheia, bem como coibir em limites a pobreza, igualmente impeditiva do desenvolvimento e regulação citadinas, pois se despossuída do mínimo necessário à sua reprodução estava fadada à ruína, mesmo porque vulnerável ao inimigo externo. Cobiça e riqueza, pois, na pena aristotélica, objetivavam-se na condição inversa da moral. A riqueza excessiva impeliria algumas cidades-estado à prática da pilhagem, porquanto a cidade invasora acreditava que, por esta via, asseguraria sua reprodução. Por isso, Aristóteles propunha a mediania de bens, que permitisse a reprodução societária, a segurança militar e a convivência relativamente tranqüila com as demais cidades sem que a cobiça despertasse. O que se põe, então, é a recorrente e estrutural condição do metro a assegurar a regulação interna e externa das cidades. Comparecia a noção de que o equilíbrio,

27. ARISTOTE, Politique, p.72. 
a justa medida de riquezas inibia a cobiça. Desse modo, o bom metro moral advinha, mediatamente, de necessidades histórico-comunitárias urgentes: a busca insistente pela reta postura na ação derivava da incontornável condição de equilíbrio que a pólis devia alcançar para se reproduzir. Assim, e isto se deve dizer, o metro moral se imbricava com o metro comunitário que o condicionava, ou, o necessário equilíbrio da pólis era fator fundamental na busca da reta medida que à individualidade se impunha. Então, e aqui claramente se pode atinar com a determinação, a ética deriva da política, vale dizer: a ética encontrava a medida pelas necessidades da comunidade, pelo télos do equilíbrio, que constituía a forma de ser das cidades-estado. O apelo à vida e à riqueza moderadas significava, no plano moral, não apenas a consciência de que a moderação representava algo positivo tanto para o indivíduo quanto para a comunidade, mas notadamente, o único modo de se situar diante de uma formação social que pouco podia oferecer aos indivíduos: a vida na pólis tinha de ser regrada pela política e pela ética, pois suas estruturas não permitiam a vida para além de uma certa medida instaurada pela baixa extensão das forças produtivas, condicionantes da vida efetiva dos homens.

Não se deve estranhar, em tal contextura, que o pensamento grego perspectivasse a felicidade em uma vida teórica, contemplativa, pois as capacidades humanas na vida concreta eram estruturalmente limitadas, contidas, medidas; e o homem helênico encontrava na filosofia, nas ciências, nas artes e na política (compreendida a ética) a própria condição do humano. A teoria era, para os gregos, o campo ilimitado do fazer-se homem, porque esta atividade, aparentemente desligada da sociabilidade que a promovia, emergia como espaço possível da construção racional da vida humana in communitas. No livro X da EN [ 1179 a], ao falar das condicionantes que animam os prepostos de uma vida feliz, afirma Aristóteles:

... é indispensável que ela disponha de um corpo em boa saúde, de uma alimentação suficiente e de outros recursos necessários. Todavia, não vamos imaginar que tais condições, e tão importantes, sejam indispensáveis para ser felizes, reconhecendo completamente que a felicidade é irrealizável sem os bens exteriores. Com efeito, a capacidade de se bastar a si mesmo e a possibilidade de agir não residem no excesso dos bens. É perfeitamente possível agir como homem de bem sem comandar a terra e o mar inteiros. Com recursos moderados, tem-se toda possibilidade de agir conforme a virtude. /.../ Sólon, ele mesmo, tinha certamente razão de declarar felizes aqueles que, moderadamente dotados de bens exteriores, não haviam realizado menos ações que ele julgava honoráveis e que haviam feito 
da temperança a regra de suas vidas. Nada impede, com efeito, que, com recursos magros, nós nos comportemos como se deve. ${ }^{28}$

Segundo o estagirita, toma forma a relação entre vida feliz e recursos moderados, forjadores de uma ética medial. Há o reconhecimento de que os bens exteriores eram meios imprescindíveis à ação ética, pois para agir bem era indispensável gozar de boa saúde e estar bem alimentado; as carências próprias do corpo precisavam ser satisfeitas para que a individualidade atuasse de modo correto e soubesse deliberar. Significa que a ação moral, do ponto de vista aristotélico, era tecida no interior da relação externo-interno que a tornava possível, ou plasmada a partir da comunidade. O agir, assim, era posto no intercâmbio com a vida citadina, pois a ação humana sobre ela operava, nela se radicava, comunidade que a possibilitava ou, ao contrário, a impedia e punia. Para Aubenque, em Aristóteles:

... a boa fortuna não basta para definir a felicidade/.../mas sem ela não há felicidade possível, em duplo sentido: inicialmente, porque a virtude necessita de uma matéria para se exercer e, como vimos, de um "mundo", ou seja, necessita de condições que não dependem de nós, como amigos, dinheiro, um certo poder político e também de ocasiões, as quais não se oferecem a todos/.../Mas, num segundo sentido, não pode haver felicidade completa sem a plenitude da vida/.../o que pressupõe, sem dúvida, uma duração optima, mas também a integridade do corpo e a prosperidade de nossos empreendimentos. ${ }^{29}$

O autor é direto ao afirmar que existia uma interdependência estrutural entre a comunidade e as ações individuais: estas dependiam de condições e relações efetivas que viabilizassem seu sucesso, do contrário, o indivíduo não encontraria os meios adequados à sua realização. E no interior desta teoria articuladora Aristóteles sustentava, e isto é preciso sublinhar posto ser o núcleo teórico deste estudo, que a reta conduta moral não emanava da abundância ou excesso de bens, com o que estabelece a paridade entre a reta conduta moral e a moderação de riquezas. De sorte que o ato moral estava imbricado à (justa) posse de bens que permitia ao indivíduo agir com temperança. E, por este pensar, que configurava o homem temperante como sendo aquele provido de recursos módicos, Aristóteles retoma a figura emblemática de Sólon (pertencente à classe média), com que ecoa, ademais, sua

28. ARISTOTE, Éthique de Nicomaque, p.313.

29. P. AUBENQUE, A prudência em Aristóteles, p.129. 
argumentação anterior no sentido de que a classe média atuava no justo-meio, visto que não necessitava dispor dos bens dos outros (como os mais pobres), e não temia a ganância dos mais ricos, que por sua própria orgânica eram, por vezes, incontinentes, ou não obedeciam à reta razão, à boa medida moral. O excesso de riqueza mostrava-se, pois, nocivo aos indivíduos, porquanto o desejo era ilimitado:

Além disso, a perversidade dos homens é um vaso sem fundo: contenta-se no início com dois óbulos, depois, uma vez tomado o hábito, tem-se necessidade de mais sem cessar, até ultrapassar todo limite; a natureza do desejo é de ser sem limite e a maior parte dos homens só vive para satisfazê-lo. ${ }^{30}$

A moderação de riquezas, em tal cenário, era importante porque moderava os apetites, ainda mais em indivíduos que viviam para satisfazê-los ilimitadamente. A riqueza imoderada tornava imoderada a pessoa que a possuía, o que significava, e este é o ponto, a desfiguração social, o rompimento posto pelo excesso, que devia ser necessariamente controlado, adstringido. Precisamente por isso, a ética encontrou suas possibilidades na justa medida, preservadora, moral que se exprimia na contenção da imoderação de riqueza e desejos, como também na superação da pobreza, igualmente dissolutiva. A ética aristotélica, reitere-se em conclusão, era o metro individual equilibrante, a medida da manutenção de uma vida em comunidade que só podia ser medial. Mediania que não se realizava espontaneamente, demandando vigor social ordenador: política e ética, em plena sintonia, que gerava simetria social, regulavam o intercâmbio entre homens e cidades.

\section{Mediania e virtude moral}

A EE e a EN, como aludido, confluem, no que concerne à categoria da mediania. Esta categoria é, para ambas atributo central, o que permite reconhecer sua importância capital. No intuito natural desta pesquisa de firmar tal relevância categorial, com o que se entende firmar a natureza da ética aristotélica, indicaremos esta centralidade pela análise das obras em separado. Iniciemos pela $E N$.

Ao principiar a caracterização da mediania, o estagirita lança mão de exemplos ligados à área de saúde, notadamente da medicina. No livro II da EN [1104 a], ao comentar

30. ARISTOTE, Politique, livre II, [1267 a], p.72. 
os males da falta ou excesso de exercícios, bem como da falta ou excesso de alimentos para o corpo, é referido o seguinte: "O exercício, seja ele exagerado ou insuficiente, altera esse vigor, do mesmo modo que o excesso e a insuficiência de bebida e alimento compromete a boa saúde, enquanto que a moderação nessas matérias cria, desenvolve e preserva a saúde. ${ }^{31}$ Sintetizando, os extremos, para Aristóteles, eram tidos como prejudiciais, inadequados, porque inviabilizavam a correta função dos entes. Ao engendrarem disfunção, o excesso e a omissão impediam o equilíbrio necessário à produção e reprodução orgânicas. Deste modo, esboça, por via de exemplos, uma tese fundamental, presente tanto em Política como na $C A$, a saber: os extremos devem ser evitados, pois prejudiciais aos indivíduos e às cidades. Assim, se firma, pois, que só o equilíbrio preservava, pois mantinha a unidade e a coesão funcionais. E, no curso argumentativo, este raciocínio afigurado de forma simples, ou nos níveis do funcionamento fisiológico, é transposto ao campo propriamente moral. Ao desdobrar as considerações [EN, II, 1106 b], Aristóteles adentra no plano ético, envolvendo as complexas relações entre a categoria da mediania, as paixões e os modos de sentir:

... os sentimentos de pavor, de segurança, de desejo, de cólera, de piedade, enfim, de prazer ou de sofrimento podem nos afetar ou muito ou muito pouco, e de uma maneira defeituosa em ambos os casos. Mas se nós experimentamos esses sentimentos no momento oportuno, por motivos satisfatórios, a respeito de pessoas que os merecem, para os fins e nas condições convenientes, nós permanecemos em um excelente meio, e é aí o lugar próprio da virtude. ${ }^{32}$

É evidente que tudo convergia para o ponto medial. Os sentimentos deviam ser sentidos no justo-meio que permitisse sua realização, isto é, dever-se-ia sentir de modo adequado, no momento adequado. O modo de sentir influenciava, decisivamente, não apenas o indivíduo que sentia em si, mas também a individualidade que sofria o impacto da paixão de outrem. As paixões, por esta análise, necessitavam da moderação e dos limites nascidos da ética, então o indivíduo devia ser educado a moderar, a coibir seus desejos e vontades a partir do metro medial, que articulava e viabilizava a vida dos cidadãos. A ética aristotélica é medial: o limite imposto pela regulação política era mediatamente assumido pelo indivíduo enquanto metro moderador a ordenar os sentimentos, numa sociabilidade em

\footnotetext{
31. ARISTOTE, Éthique de Nicomaque, p. 54.

32. Ibid., p. 61.
} 
que o equilíbrio é atributo social de fundo. Em suma, moderar desejos e paixões implicava moderar atitudes e ações, e coibir os desejos significava, concretamente, satisfazer em adstringência as demandas individuais. A mesma tônica ideal, como era de se esperar, é desdobrada com relação às ações em EN [II, 1106 b]:

Da mesma maneira, encontram-se nas ações excesso, falta e justo meio. Assim, então, a virtude se relaciona com as ações como com as paixões. Aí, o excesso é um erro e a falta provoca a censura; em contrapartida, o justo meio obtém elogios e o sucesso, duplo resultado próprio à virtude. A virtude é, então, uma espécie de meio, pois o fim a que ela se propõe é um equilíbrio entre dois extremos. ${ }^{33}$

No centro das considerações, a mediania. Ora, cumprir bem a natureza humana significava, para Aristóteles, fazer - nos casos aludidos acima - com que a força, a saúde, os sentimentos e as ações se manifestassem de modo adequado, isto é, que atuassem em sua plenitude - em rígido equilíbrio. Dito de outro modo, cada ser possuía uma certa orgânica, que só era passível de desenvolvimento e efetivação se a mesma ganhasse os contornos da justa medida. Daí, o justo meio era a forma pela qual as coisas se realizavam dentro de seus próprios limites. Para mais ou para menos, ao exercitar os extremos, a função se desequilibrava, como os afetos e a ação, exercício intrinsecamente gerador de uma descompensação, de um desgaste maior do que o suportável. Destarte, como apontado no capítulo dedicado à teleologia aristotélica, a justa-medida permitia a auto-regulação e os entes, assim efetivados pela medida e ordem, reproduziam a comunidade: tender ao metro constituía a lógica e o modus operandi da natureza, e, em certa medida, dos homens, para os quais a ação virtuosa era a ação no equilíbrio, criando a possibilidade de sucesso e de louvor. Em EE [II, 1220 b 30], o cenário teórico espelha esse quadro decisivo, como se pode ver:

Com efeito, é evidente por indução e por argumentação: pois os contrários se destroem um ao outro, e os extremos são contrários um em relação ao outro e em relação ao intermediário, pois o intermediário é o outro em relação a cada um dos dois, por exemplo, o igual é maior que o que é menor, mas menor que o que é maior. Também é necessário que a virtude ética tenha por objeto os intermediários e que ela seja uma certa média. ${ }^{34}$

33 . ARISTOTE, Éthique de Nicomaque, p.61.

${ }^{34}$. ARISTOTE, Éthique à Eudème, p. 89. 
Em outros termos, o equilíbrio preservava, de sorte que nossas ações deviam se pautar pela virtude, que está no meio; do contrário, predominariam os extremos, que tendiam à destruição recíproca. Tem-se que, em Aristóteles, a dimensão intermediária era a mola social reprodutora, a qual remetia não somente à ética, mas, como colhido do livro V da $E N$, era a base da própria justiça, da igualdade entre cidadãos. Deste modo, ética e política se articulavam num objetivo comum: na imposição de limites que permitissem a ordem individual e comunitária, a integração indivíduo-comunidade na sociabilidade do limite. Posto isto, é pertinente desdobrar outras considerações sobre a virtude e sua relação com a medida, com o que se substancia o cerne da argumentação elaborada. No livro II da EN [1106 a 30], ao descrever a medida ética, o autor assinala a presença marcante e substantiva do indivíduo, e a mediania moral - ou o metro - é caracterizada a partir de sua natureza e de seu ser. Eis a reflexão:

\footnotetext{
Em relação a nós, eu chamo de moderação o que não comporta nem exagero, nem falta. Ora, no nosso caso, essa moderação não é nem única, nem idêntica em todos os casos. Por exemplo, seja a dezena quantidade muito elevada e dois, quantidade muito débil. Seis será a média em relação à soma, porque seis ultrapassa dois por quatro unidades e é inferior a dez na mesma quantidade. Tal é a média segundo a proporção aritmética. Mas não é preciso contemplar as coisas desse modo em relação a nós. Não concluamos do fato que dez minas de alimento constituam uma forte ração e que duas minas uma ração débil, que o mestre de ginástica prescreva seis a todos os atletas. Pois uma tal medida pode ser, segundo a pessoa, excessiva ou insuficiente. Para Milo, ela pode ser insuficiente, mas para um iniciante ela pode ser excessiva. /.../ Assim, todo homem prevenido foge do excesso e da falta, procura o bom meio e lhe dá preferência, meio estabelecido não relativamente ao objeto, mas em relação a nós. ${ }^{35}$
}

Na realidade, o estagirita repõe o argumento de base de que a ação ética se plasmava pelos movimentos da subjetividade agente, ou aquela que reconhecia a medida daquilo que devia ou não fazer. Em outros termos, o metro surgia pela avaliação do indivíduo da situação ou circunstância que se lhe defrontava e sobre a qual atuava; era aí que se forjava o caminho adequado, o equilíbrio que comportava, se necessário, certo desequilíbrio, pois a medida se punha a partir das possibilidades do agente em face da situação. Igualmente,

\footnotetext{
${ }^{35}$. IDEM, Éthique de Nicomaque, p.60.
} 
Aristóteles exercitava o respeito à ordem das coisas, porquanto as ações tomavam arrimo em avaliações atentas e criteriosas que permitissem ao agente inferir objetivamente, isto é, na conexão que unia e atava indivíduo e comunidade. Ao distinguir entre a mediania relativa a nós e aos objetos, o filósofo determinava a medida a partir da relação entre indivíduo e mundo. A medida, que era equilíbrio, encontrava-se entre o que o agente fazia e aquilo que as condições permitiam e demandavam. Deste modo, as ações passavam a ser regidas pelo campo dos possíveis, longe das certezas matemáticas e das necessidades da legalidade natural. Significava que o desafio ético era encontrar a mediania possível, desejável, sem nenhum apelo ou pré-condição, de modo que a moralidade ganhava o arrimo e o peso da comunidade política, na exata medida em que o indivíduo moral era o animal político. Os indivíduos reconheciam os próprios limites e os limites inerentes às situações em que atuavam; logo, a ética permitia ao indivíduo não apenas agir bem, mas, e isto é fundamental, identificar as condições da sociabilidade, e assim agir na direção de enformar os desejos e vontades que se coadunavam à reta medida, isto é, ao seu próprio existir.

Desenhado, enfim, todo o quadro de ações, para fins conclusivos, esboça-se o eixo que dá forma e vivifica a ética nicomaquéia: a caracterização das virtudes morais enquanto apelo dramático à justa medida; marca decisiva da cultura helênica a substanciar o metro individual que se atava ao metro social, a política, confirmando-o.

Tanto EE como EN, ambas no livro III, iniciam suas considerações sobre as virtudes morais tomando a coragem, que se punha na medida entre o medo e a temeridade. A coragem era reconhecida em sua dimensão cívico-militar, pois ligada à capacidade do cidadão de enfrentar os problemas, os perigos postos na vida da cidade, e exercer, de forma efetiva, sua administração e defesa. Evidente a imperiosa necessidade grega de fomentar o espírito cívico, que engendrava no indivíduo as condições morais que o tornavam apto a enfrentar tais problemas citadinos perenes. Frise-se, a coragem era virtude imediatamente condicionada às demandas ingênitas das cidades-estado, pois, essencialmente frágeis, necessitavam educar os cidadãos de modo aguerrido, condição para que interferissem nas urgências cotidianas. Em EE, livro III, [1229 a 15], lê-se:

A primeira coragem é a coragem cívica: é essa que é devida à honra. A segunda é a coragem militar: ela é devida à experiência e ao fato de conhecer não, assim disse Sócrates, o que é perigoso, mas os recursos que se terá no perigo. A terceira é a coragem devida à inexperiência e à ignorância, que faz 
com que os loucos suportem o que lhes acontece, que as crianças peguem serpentes em suas mãos. Um outro tipo de coragem é devido à esperança: ela faz com que aqueles que têm tido sorte freqüentemente suportem os perigos, do mesmo modo que as pessoas bêbadas, porque o vinho lhes enche de esperança. Uma outra é devida a um sentimento irracional - como o amor e a cólera. ${ }^{36}$

Delimita-se o centro medial da coragem citadina como: a educação do caráter, a honra, que armava o indivíduo para o combate estruturalmente existente. A coragem era virtude do homem que se imbuía de um sentimento capaz de responder aos desafios guerreiros da pólis, de sorte que a coragem era filha do solo social citadino, no qual os homens realizavam atos corajosos por necessidades concretas, não por apelos subjetivos, normativos ou mesmo extrínsecos às urgências comunitárias. A coragem compreendia relações orgânicas com o solo societário, irrompendo como o modus faciendi do indivíduo a serviço da comunidade.

A segunda virtude abordada pelo estagirita diz respeito à temperança, que outrossim implica relação direta com os apetites e desejos: "Sobre a temperança, nós já dissemos que ela constitui um justo meio relativamente aos prazeres."[III,1117 b $]^{37}$ A temperança constituía o modo adequado pelos quais os indivíduos se relacionavam com os prazeres do corpo, notadamente os do tato e do paladar. Esta virtude era reconhecida importante porquanto estabelecia a moderação num terreno sabidamente imoderado, aquele do comer e do sexo. Nesse sentido, Aristóteles, chega a comparar o homem intemperante aos animais, pois “É então com os prazeres desse tipo que têm relação a temperança e a destemperança; os outros seres vivos compartilham deles; eles também parecem de natureza servil e bestial: são aqueles do tato e do gosto".[III, 1118 a 25] ${ }^{38}$ Em $E N$, pois, reconhece-se o quanto era negativa a sobreposição dos desejos em relação à vontade racional, pois a incapacidade dos indivíduos de impor limites àquilo que por si não conhecia limites, desqualificava o agente como indivíduo apto a atitudes adequadas em situações imprevisíveis e adversas. Em termos concretos, se o homem era incapaz de se autogovernar, como poderia administrar a pólis ou defendê-la? Na prática, a intemperança obstaculizava o agir, na medida em que impedia que

${ }^{36}$. ARISTÓTE, Éthique à Eudème, p. 122.

37. IDEM, Éthique de Nicomaque, p.97.

38.Ibid., p.98. 
toda e qualquer virtude pudesse ser exercida pelo hábito e adquirida como referência no atuar in communitas. Dispõe Vergnières sobre o homem intemperante:

Os prazeres do intemperante são os que o homem partilha com o animal, os prazeres do tato. É, pois, a figura do glutão/.../que simboliza melhor esse caráter. O intemperante é o homem do consumo, do gozo, que, por seus desejos insaciáveis, acresce a força inata da cupidez. Ele renega também sua humanidade. $^{39}$

A intemperança, pois, é imoderação, ausência de limites, condição que tornava a individualidade refém dos próprios desejos, destarte, isolando-a do convívio e dos propósitos da vida citadina. Assim, no afastamento da comunidade, ao satisfazer desmedidas necessidades privadas, o intemperante truncava os laços pelos quais sua própria subjetividade se efetivava, interferindo negativamente na vida citadina, já que a vida imoderada, não podia ultrapassar os limites e regras que equilibravam a comunidade. De sorte que a intemperança, forjada no ato impulsivo, desviado de um justo-meio, era conflitante, como tudo, ademais, que transcendesse as adstringidas possibilidades da pólis, que moderava o indivíduo. Enfim, o desgarrar da vida in communitas que a intemperança promovia era malefício não apenas para o indivíduo, mas, antes e acima de tudo, para a comunidade que, enfraquecida pela desequilibrada ação individual que se desprendia do coletivo e fundamentalmente por isso tida como desequilíbrio, via contradito seu intrínseco caráter medial fundante. Intemperança, indivíduo, em última análise, que desconsiderava o todo:

A intemperança se caracteriza pela aflição desproporcional que se sente quando se é privado daquilo que dá prazer - efetivamente, dir-se-á que é o prazer que causa a dor; o temperante, ao contrário, não manifesta qualquer dor diante da privação daquilo que lhe é agradável. O intemperado deseja todas as satisfações e sobretudo aquelas que lhe tocam mais; seu desejo o conduz ao ponto de o fazer preferir seu deleite a todo o resto. ${ }^{40}$

No exame e determinação do homem liberal, Aristóteles estabelecia a relação entre liberalidade e uso moderado de bens. No livro IV de EN [1119 b 25], aponta:

39. Solange VERGNIÈRES, Ética e política em Aristóteles - physis, ethos, nomos, p.113.

${ }^{40}$. ARISTOTE, Éthique de Nicomaque, [III, 1118 b e 1119 a], p.100. 
Falemos agora da generosidade. Essa qualidade parece ser um justo meio em relação ao uso dos bens. Louva-se o generoso não em razão de sua atitude na guerra, não por razões que o fazem temperante, muito menos seus julgamentos; faz-se seu elogio por sua maneira de dar e de receber o dinheiro; sobretudo por sua maneira de dar. /.../ A prodigalidade e a avareza grosseira designam o excesso e a falta no uso das riquezas. ${ }^{41}$

Desdobrando a palavra de Aristóteles, o modo como os indivíduos se relacionavam com seus bens era humanamente importante, porque não se tratava apenas do âmbito pessoal, mas da família, e da comunidade. A avareza era condenável porque o avaro amava a riqueza acima de tudo. Significa, e esta era a razão da condenação, que os bens se realizavam em dimensão estritamente particular, descolados de todo e qualquer uso cívico, portanto, em oposição à comunidade. A prodigalidade, igualmente, que é o inverso, condenava-se porque aquele que gastava de modo compulsivo e imoderado era incapaz de colaborar civicamente com a comunidade, mesmo nas situações adversas como guerras e calamidades. De tal forma que avareza e prodigalidade, desvios da reta medida, eram características negadas visto que afastavam os homens da vida in communitas, do comprometimento com os problemas públicos, com os afazeres dos cidadãos. Ao gastar de forma imprudente suas riquezas, o homem iliberal fazia-se refém de si, de sua natureza irracional que passava a comandar vontades e apetites. Aristóteles não identificava prodigalidade e incontinência, mas ressaltava que em casos específicos os dois vícios se aparentavam, tomavam uma feição comum. O certo é que só a liberalidade, o equilíbrio, a moderação, permitiam ao homem virtuoso dispor de seus bens de modo adequado: no possuir e conceder riquezas a outrem na justa medida, o homem liberal, o que se supõe primariamente, colaborava com os cidadãos, arrimando e fortalecendo a cidade, portanto, sua vida in communitas.

No que concernia à magnificência, tal virtude pertencia àqueles cuja condição permitia gastos vultosos com ações nobres. Aristóteles entendia o magnificente enquanto aquele capaz de realizar festas cívicas, culto às divindades, espetáculos públicos, manutenção e guarnição de trirremes. ${ }^{42}$ Então, o magnificente concedia à comunidade, por meio de recursos próprios, a unidade que atava e animava a vida citadina. Por sua mediação,

\footnotetext{
41 . ARISTOTE, Éthique de Nicomaque, p.105.

${ }^{42}$. Cf. ARISTOTE, Éthique de Nicomaque, p. 113-4.
} 
o interesse público emergia e se renovava, a partir das honrosas ações comunais que empreendia, ações substancialmente importantes para fortalecer o espírito cívico dos cidadãos. A magnificência, desse modo, era própria dos cidadãos mais ricos, em que a riqueza tomava a forma de meio, de justo meio, ou instrumento a promover os interesses coletivos. Inversamente, o cidadão rico que não se dispunha a colaborar com o bem público, era entendido como mesquinho, ou aquele que, longe de abraçar os destinos da comunidade, tomava a riqueza para fins meramente pessoais, ou de seus familiares, riqueza que, antes de se realizar como meio comunal, operava como peso desagregador, ao contrapor indivíduo e comunidade. Não obstante, e aqui se conclui este passo argumentativo, o inverso da mesquinhez não era tomado, aristotelicamente, como menos pernicioso e danoso à cidadeestado. Ora, aquele que gastava privadamente de modo desmedido sangrava os recursos da comunidade, pois quantias que deveriam ser, de um ou de outro modo, a ela destinadas, desaguavam em bolsos privados, os quais, muitas das vezes, possuíam pretensões familiares de ascensão política, situação que, desestabilizava estruturalmente o frágil equilíbrio insistentemente observado e duramente sustentado pela pólis.

Por fim, a prudência, virtude caracterizada no livro VI de EN. Frise-se, inicialmente, que a discussão acerca da importância e do contexto da prudência (phronesis) no interior da EN sempre gerou inúmeros embates por parte dos estudiosos. Desde W. Jaeger, passando por H.G. Gadamer, René-Antoine Gauthier e P. Aubenque, o tema sobre a phronesis nunca foi pacífico, suscitando polêmicas e divergências. Na medida em que envolvia um certo tipo de conhecimento prático, a phronesis presente em EN, pontualize-se aqui, seria um contraponto ao conceito de phronesis encontrado na Metafísica, pois se assemelharia mais à sophia. De modo que as polêmicas discussões reconhecem dois sentidos para a palavra phronesis, que poderiam, ou não, opor-se, ou, ainda, ser o resultado do desenvolvimento e amadurecimento intelectual de Aristóteles. Seja como for, nosso objetivo, que escapa à polêmica, é o de precisar como a phronesis, no campo moral, determinava a prudência enquanto moderação a deliberar acerca dos atos, do que nasce uma imposição de limites ao homem grego na execução cotidiana de suas ações. Em EN [VI, 1140 a 25], Aristóteles considera:

Nós estaremos em condições de discernir o que é a prudência, estudando primeiramente aqueles a que se chamam as pessoas prudentes. Parece bem que o que os caracteriza é o poder de decidir 
convenientemente o que é bom e útil para eles mesmos - não parcialmente, como nos casos do que é proveitoso à saúde e ao vigor, mas, em geral, no que concerne à felicidade ${ }^{43}$.

Da leitura, depreende-se que o homem prudente deliberava não apenas e especificamente sobre coisas particulares ou privadas: era obra do homem prudente deliberar bem sobre coisas boas e úteis enquanto partícipe do universo comunitário, de modo que bom e útil eram possibilidades ou condições que se enraizavam num contexto, ou melhor, na comunidade. Aristóteles, pois, reconhecia na prudência um valor essencialmente público, na medida em que a deliberação do homem prudente se articulava no enlace entre vida privada e vida pública, vale dizer, o homem prudente era verdadeiramente ético na medida em que sabia deliberar atando e unindo os interesses comunitários e a vida particular do cidadão. Deste modo, a prudência era virtude efetiva quando resultado da conexidade entre vida privada e pública, ou seja, a felicidade - que era meta do homem prudente - só se efetivava se o público e o privado coexistissem na interação de propósitos, então, o equilíbrio da vida citadina nascido da prudência se punha na concatenação público-privado, os quais possuíam os mesmos fins. Deliberar sobre a felicidade - que era obra do homem prudente - subtendia a conexão ativa e carnal entre indivíduo e comunidade, uma vez que como já observado no livro I da $E N$, a felicidade do indivíduo era parte substancial da felicidade in communitas, ou, sua felicidade só se realizava in communitas. ${ }^{44}$ Logo, à prudência era intrínseca a capacidade de deliberar na reta medida: o homem prudente não apenas deliberava a partir das circunstâncias e das experiências acumuladas, mas, essencialmente, tomava como referência os efeitos - positivos ou não - que sua ação podia gerar à comunidade.

Assim, não era outro o sentido de homem prudente atribuído a Péricles, na exata medida em que sua ação configurou o enlace decisivo entre público e privado [VI, $1140 \mathrm{~b}$ 10]: "É por esta razão que reconhecemos a prudência em Péricles e aos indivíduos deste mesmo gênero: eles se mostram capazes de determinar o que é vantajoso para si mesmos e para os homens". ${ }^{45}$ Nesse aspecto, a phronesis não constituiu apenas a virtude da parte calculadora ou opinativa da alma, inserida entre a parte racional e irracional mas, inversamente, a prudência era subjetividade objetiva - realizava-se no reconhecimento das

43. ARISTOTE, Éthique de Nicomaque, p.174.

44. Cf. ARISTOTE, Éthique de Nicomaque,p.22-3.

45 . ARISTOTE, Éthique de Nicomaque, p.175. 
necessidades reais dos cidadãos e da comunidade, na felicidade parida in communitas. Destarte, o homem prudente reconhecia os limites em que vivia e que devia respeitar, homem cuja felicidade possível se urdia na relação que o atava à comunidade, que era terra da moderação, condição própria e ingênita da vida da pólis, como uma vez mais se alcança vislumbrar.

No que tange à phronesis, uma outra questão, atinente, que arremata. A sabedoria prática supunha situações variáveis, um universo plural, porque contingente. Significa que a prudência operava no interior de um campo mais geral, de valores genéricos, de talhe universal, mas que também se articulava no singular, especificando a realidade concreta da prudência. Nos termos de Aristóteles [EN, VI, 1141 b]:

A prudência /.../ tem por objeto o que é próprio ao homem e aquilo sobre o que se pode exercer a deliberação. O que caracteriza o homem prudente, sobretudo, nós voltamos a dizer, é a deliberação bem conduzida. Ora, ninguém delibera sobre aquilo que tem um caráter de necessidade, nem sobre algo que não assinala algum fim, mas sim sobre aquilo que constitui um bem realizável. /.../ Acrescentemos que a prudência não tem por objeto somente o geral; é preciso também que ela conheça as circunstâncias particulares; porque ela visa à ação e a ação tem por objeto os casos individuais. $^{46}$

No interior da afirmação que a sabedoria prática deliberava sobre as coisas humanas, Aristóteles, dispunha que a phronesis deliberava sobre o particular, mas isto a partir do que era próprio ao homem; significa dizer, sem dúvida, que a sabedoria prática optava pelo possível, único caminho para que a deliberação humana encontrasse um bom termo social. Nesse sentido, a pena filosófica promovia o enlace indivíduo/comunidade, o que implicava, in limine, que a ação do homem prudente era sintética, visto viabilizar a ordem comunitária ao buscar a felicidade na harmonia da cidade-estado. Melhor dizendo, um bem exeqüível, que na phronesis correspondia à felicidade, era perspectiva que envolvia pretensões individuais gestadas em solo comunal. E, é vital traçar o paralelo, a justiça, como Aristóteles afirma no livro $\mathrm{V}$ de $E N$, era a justiça política que envolvia atos que buscavam produzir e preservar o equilíbrio necessário à reprodução societária, nesse sentido, a felicidade. ${ }^{47}$

\footnotetext{
46 Ibid., p.178.

${ }^{47}$.Cf. ARISTOTE, Éthique de Nicomaque, p.137.
} 
Equilíbrio que, nas palavras de Aubenque, reverberam a phronesis como saber do homem que encontrava e punha-se pelo reconhecimento de seus próprios limites:

... a phronêsis é o saber, embora limitado e consciente, de seus limites; é o pensamento humano, que se sabe e se quer humano. Determinação intelectual enquanto atributo do homem, mas de um homem consciente de sua condição de homem; qualificação moral, pois há algum mérito em limitar seu desejo natural de conhecer, sem tentar rivalizar com os deuses, e a limitar ao homem e a seus interesses um pensamento que inspira ou que previne a cada instante a tentação sobre-humana ${ }^{48}$.

É necessário citar que, Aubenque reconhecia na prudência um saber autoconsciente, isto é, o homem prudente reconhecia limites e por percepção era levado a agir de modo satisfatório. A identidade no limite facultava o reconhecimento de suas possibilidades, limitadas, de suas diferenças em relação aos deuses. Aubenque expressa a identidade grega do limite, que facultava, justamente, a ação objetiva: o conhecimento dos limites de si e de sua comunidade era presença efetiva do homem prudente, pois do contrário, as ações desrespeitariam o modus operandi e a lógica de ser da comunidade. Ao reconhecer limites, o homem prudente agregava condições, mesmo que adstringidas, de constituir sua sociabilidade, plasmada então nos padrões da justa medida. A moderação permitia ao indivíduo forjar espaços sociais nos quais seus atos, sempre cerceados, encontravam eco real, pois unidos às condições apoucadas da sociabilidade grega tais atos se tornavam construtivos, mantenedores da sobrevivência da comunidade. Na iteração ora inconteste: o metro ético era, essencialmente, a medialidade do homem grego, os limites de suas ações na constituição da vida citadina. Então, a medida ética emanava da dinâmica e relações apoucadas da cidade-estado: a ética consubstanciava o fazer e o desejar de um homem cujo parâmetro era dado pelas possibilidades da vida social, de suas forças produtivas amesquinhadas, de uma vida sempre incerta. Vale, aqui, e como movimento conclusivo, tomar Vergnières a propósito do vínculo entre ética e formação social, conquanto de seu argumento não se desdobrem efetivamente estas relações:

A contradição entre trabalho e cidadania varia, contudo, em função das tarefas consideradas. Na Política, VI, Aristóteles estabelece uma hierarquia entre diversos dêmos e diversas formas de democracia. O melhor povo, diz ele, é o povo composto de cultivadores ou de pastores. A atividade

\footnotetext{
48. P. AUBENQUE, A prudência em Aristóteles, p.256.
} 
agrícola, com efeito, desenvolve certo número de virtudes morais como a coragem e a temperança. O agricultor é vigoroso, apto a permanecer fora como homem (e não como mulher), apto a defender pela guerra seus bens expostos fora da cidade: em suma, é bom soldado. Ademais, não é invejoso, contenta-se em gozar os produtos de seu labor, sem desejos ilimitados; é, pois, 'temperante'. ${ }^{49}$

O teor do texto é relevante, já que marca o nexo que o próprio Aristóteles estabeleceu entre determinadas formas de trabalho e a condição moral dos indivíduos. O trabalho no campo, não poderia ser de outra forma, era reconhecido como aquele capaz de estabelecer um padrão de virtudes nada desprezíveis. Significava que a coragem e a temperança enformavam o contorno subjetivo do camponês, que assim era considerado também um bom soldado, aguerrido e afeito a seus afazeres. Por fim, do camponês era traçado um perfil moderado, contido, contrário ao esbanjamento, que se inseria, pois, em limites claros e assumidamente modestos. Tal postura revelava valores em que não cabia a inveja ao trabalho e aos bens alheios. Essa afiguração de caráter, o reconhecimento da dimensão positiva e moralizadora do trabalho agrícola era, sem dúvida, compreensível, ainda mais num contexto determinado pela propriedade da terra, de seus frutos e de sua orgânica vitais. Então, e isto é o que importa frisar, na ética dos limites, o camponês - sinônimo de virtude -, era fruto da ordem social limitada, de satisfações humanas limitadas e da pouca ou quase nenhuma transformação da natureza. E, finalmente, uma ética do limite se punha porque uma sociedade assim se constituía; limite que, moldando o indivíduo, moldava a comunidade; limite que era vida política, política que era limite; ética do justo meio, pois para além disso não havia além.

49. Solange VERGNIÈRES, Ética e política em Aristóteles - physis, ethos, nomos, p.178. 


\section{O N C L U S Ã O}

O desafio de expor, sumariamente, a trama categorial que sustentou os propósitos e as amarras conceituais deste trabalho é, em síntese, objetivo desta conclusão. Trata-se, em última instância, de precisar argumentos e determinações dispostos ao longo do estudo, movimento que pretende, pois, rigor teórico. Assim, entendemos a conclusão não apenas como a reafirmação sintetizadora do já dito, mas, frise-se, como momento de reiteração da teia capital que articulou e vivificou a determinação da politicidade em Aristóteles, objetivo maior desta pesquisa, como também, ainda, de seu correlato imediato: a ética. Buscamos, então, demonstrar como a política e a ética se coadunam, enquanto instrumentos comunitários, para regular e preservar a vida citadina. Nesse sentido, a política (que compreende também a ética) nasce das adstringências da comunidade política grega, determinação esta que se buscará desdobrar no intento de sua reafirmação. Vejamos, pois.

\section{Pensamento e objetividade.}

Em Aristote. La politique des citoyens et la contingence, Michel-Pierre Edmond elabora, logo nas primeiras páginas, um perfil analítico do discurso aristotélico que ressalta explicitamente a propensão do estagirita para a objetividade, elaboração que encontra eco em nossas considerações. Ao explicitar o domínio próprio do discurso aristotélico, Edmond tece considerações que radicam os propósitos deste trabalho, pois as categorias examinadas pelo estagirita, afirma, são, essencialmente, constituídas a partir de sua percepção objetiva, ou melhor, são categorias que se atam ao reconhecimento das principais dimensões da vida citadina de sua época. Dito diversamente, as categorias filosóficas, em mãos aristotélicas, revelam preocupações concretas e urgentes das cidades-estado, são testemunho de uma época agonizante, que perdia gradativamente a autonomia política, conseqüência incontornável do enfrentamento dos grandes desafios internos; como também, externamente, da subsunção aos desígnios dos grandes impérios, macedônico e, posteriormente, romano. 
A reflexão de Edmond que segue, por exemplo, vislumbra a inclinação aristotélica à objetividade:

... o filósofo não examina a qualidade "coragem”, tomada em si ou nela mesma, porque ela não pode ser destacada de tal ou qual homem corajoso, que age numa dada situação, em relação a um dado contexto e a um determinado tipo de fim perseguido. A qualidade "coragem" não pode, então, ser transportada a um logos, independentemente da realidade. O discurso aristotélico explicita o sentido e o valor das práticas reais./.../ Do mesmo modo, seu discurso não pode construir modelos políticos que transcenderiam sua realização possível. Para ele, os fins a que se propõe a política são "factíveis"; eles não excedem as capacidades humanas. /.../ O logos aristotélico /.../ se desenvolve num discurso descritivo e discursivo comparável a um caminho a percorrer, que nos dá o sentido de realidades, não como sentido de uma palavra, mas como sentido da marcha ou do movimento. ${ }^{1}$

Edmond, pois, revela, com propriedade, e é isto que se quer frisar neste contexto conclusivo, dimensões do discurso aristotélico que se imbricam com nossas determinações. Ao reconhecer, no plano sensível, o homem corajoso e suas implicações enquanto indivíduo pertencente à cidade-estado, o estagirita, afirma Edmond, enforma um pensamento voltado à realidade prática, a concreções reais que alimentam positivamente suas idéias e conceitos. Em termos distintos, as categorias da politicidade e da ética, enquanto categorias que espelham um conteúdo concreto, real, de homens que se articulam na vida in communitas, promovem a possibilidade de uma análise mais substantiva. Vale dizer que se as categorias expressam realidades vivas, seus conteúdos revelam o tecido social; análise, pois, rica em determinações sensíveis, efetivas, que denotam não apenas os supostos do autor, mas, concretamente, a condição da objetividade com a qual o estagirita tende a se apoderar, subjetivamente, ou ao menos se aproximar, de fato, da lógica da pólis.

Do mesmo modo, Richard Bodéüs, em Le philosophe et la cité, ilustra o envolvimento ideal do estagirita com os problemas reais da pólis ao afirmar que "As obras que lemos hoje, as Éticas e a Política, testemunham um esforço para resolver os problemas suscitados pela vida do homem em terra grega, no século IV antes da nossa era”. 2 De fato, a observação de Bodéüs corrobora o argumento de Edmond que compreende o discurso aristotélico no logos descritivo atado ao movimento concreto das coisas, ou seja, na marcha que elucida, dentro das possibilidades de um tempo

\footnotetext{
${ }^{1}$. Michel-Pierre EDMOND, Aristote. La politique des citoyens et la contingence, p.12.

${ }^{2}$. Richard BODÉÜS, Le philosophe et la cité, p. 96.
} 
histórico específico, o modo de vida grego. Destarte, é significativo que a análise aristotélica tome o homem corajoso, não a coragem, pois a intelecção da coragem enquanto dimensão ou arquétipo desgarrado dos homens reais - é própria de uma subjetividade que substantiva um predicado (a coragem) descarnado, abstrato, ao invés de examiná-lo no sujeito, nos homens efetivos, que de fato substantificam ou vivenciam a coragem por razões prático-objetivas. Deste modo, as determinações aristotélicas da política e da ética configuram categorias que explicitam o modus operanti da cidade e do indivíduo, suas implicações e relações necessárias. Em síntese, demarca, com nitidez, que a filosofia aristotélica "exprime a riqueza e o movimento de determinações inerentes à realidade”. ${ }^{3}$ Curiosamente, Maurice Croiset, já em 1932, no clássico La civilisation de la Grèce antique, dispunha acerca da dimensão objetiva de Aristóteles quando assinalava:

Ele nasceu observador. O sentido da exatidão, a necessidade da precisão, a paixão pela pesquisa se associavam nele à permanente fineza de espírito e à força do pensamento. Foi por ter sabido submeter o estudo dos fatos a um método firme e argumentado que ele aparece como o mais excelente representante do espírito científico na antigüidade; dizendo melhor, como um dos pais da ciência moderna. ${ }^{4}$

E, ao asseverar que o autor da Política demarcara o homem na particularidade que o faz ser um ente citadino, Edmond reafirma a força científica da filosofia de Aristóteles:

... ser humano se descobre sob essa forma do homem determinado por seu espaço, que a natureza produziu como espécie familiar e política. Ele encontra nessa determinação específica uma coerência interna, os fins que persegue, mas também o lugar que lhe é próprio na ordem do cosmos ou, ao menos, da Terra; ele pode se situar em relação aos outros seres vivos, definíveis como ele de acordo com a espécie a que pertencem. ${ }^{5}$

Edmond manifesta, pois, a objetividade do pensamento aristotélico nos termos da determinação que faz do homem um ser naturalmente político, distinto dos demais seres vivos, cuja ordem e objetivos particularizam sua espécie e determinam sua essência. Em verdade, como sustentamos ao longo deste trabalho - e, então, não poderia

\footnotetext{
${ }^{3}$. Michel-Pierre EDMOND, Aristote. La politique des citoyens et la contingence, p. 12.

${ }^{4}$. Maurice CROISET, La civilisation de la Grèce antique, p. 216.

${ }^{5}$. Michel-Pierre EDMOND, op. cit., p. 22.
} 
ser diverso -, as categorias da política e da ética configuravam determinações a partir de observações empíricas, mobilizando a comunidade e os indivíduos à ordem e ao equilíbrio tão necessários à reprodução da vida citadina. Edmond reforça este cenário determinativo, ao assinalar a dimensão pessoal de Aristóteles que

situa-se desde o início na perspectiva dos cidadãos e não naquela de um observador exterior à vida política. Essa perspectiva, podemos chamá-la o look, o look político, quer dizer, os modos pelos quais os cidadãos exprimem o que eles fazem e os fins a que eles visam em termos de avaliações quando, com ou sem razão, eles estimam justos ou injustos, úteis ou nocivos. ${ }^{6}$

Edmond situa o discurso aristotélico em raízes histórico-culturais, pois o estagirita se afirmava a partir de sua própria dimensão citadina, isto é, seu ser e reflexão se arrimavam na sua condição de cidadão, que vivia e se substanciava diretamente das experiências da cidade-estado e que buscava as soluções possíveis para sua continuidade e sobrevivência. De fato, o look apontado por Edmond, possibilitava ao estagirita discernir, a partir de suas condições sociais, os problemas relevantes e estruturais das cidades-estado, de sorte que as soluções filosoficamente apontadas, mesmo que limitadas, para o devenir da vida citadina, fundavam-se em terreno imanente. Em outros termos, a condição ou posição em que se encontrava Aristóteles (sua condição de cidadão) lhe permitiu, conquanto parcialmente, forjar um discurso concreto, positivo, enraizado no sensível. Discurso, pensamento, filosofia que, inclinada à imanência, o empurrou ao reconhecimento das urgências vividas pelas cidades-estado, como também o levou ao entendimento e à determinação da política e da ética, enquanto instrumentos reguladores da vida grega, como instrumentos de intervenção, como esferas ativas de uma vida real, como mediação concreta à constituição ou sobrevivência de uma cidade-estado em crise; sentido ou dimensão que fez da política, no plano sensível, a esfera a assegurar o limite, que reproduz a vida limitada. Note-se que a ideologia política de Aristóteles é expressão das carências vitais vividas pela pólis helênica, de sorte que a política e a ética, em seu ideário, apresentam relações carnais com o solo social grego, situação teórica fruto de uma filosofia que se orienta no sensível, e que por isso traduz, de forma mais ou menos aproximada, a lógica da sociabilidade grega, o que significa dizer que seu pensamento se realiza na busca da imanência, mediação real do reconhecimento da dinâmica da comunidade ateniense. Em

6. Michel-Pierre EDMOND, Aristote. La politique des citoyens et la contingence, p.17. 
outras palavras, a consciência é, em verdade, o exercício humano da compreensão, determinação, valoração, ou qualquer outro nível relacional que o homem estabeleça com o mundo. Marx, em afamada passagem de A ideologia alemã, afirma:

\footnotetext{
São os homens que são os produtores de suas representações, de suas idéias etc., mas são os homens reais, ativos, tal qual são condicionados por um desenvolvimento determinado de suas forças produtivas e do comércio que lhes corresponde, até nas suas formas as mais compreendidas. /.../ Por conseguinte, a moral, a religião, a metafísica e todo o resto da ideologia, assim como as formas de consciência que lhes correspondem, não conservam mais sua aparência de independência. Elas não têm nem história nem desenvolvimento; ao contrário, são os homens que, ao mesmo tempo que desenvolvem sua produção e sua comunicação materiais, transformam, com essa realidade que lhes é própria, seu pensamento e os produtos deste. ${ }^{7}$
}

Vale dizer, e de modo sumaríssimo, Aristóteles ata política e ética à história, buscando, concretamente, orientar as ações dos homens, movimento que significou a edificação de um fazer adstringente: seja a política sobre a formação social grega, seja a ética, da comunidade, sobre os indivíduos. Assim, rememoremos, em termos pontuais, algumas implicações históricas que determinaram a configuração do ideário políticoético de Aristóteles.

\section{A Grécia clássica: entre o apogeu e o declínio.}

A história helênica, sem dúvida, marcou em profundidade o pensamento político e as intenções do filósofo, tanto mais se levarmos em consideração o período em que viveu; tempos que se afirmavam por um presente incerto, instável e dissolvente face aos momentos de glória (passado relativamente recente) vividos pelo império ateniense: a expansão da democracia, interna e externamente; o pagamento da mistoforia; a colonização de novas terras; o apogeu militar e sua rivalidade com Esparta. Aristóteles viveu o declínio ateniense expresso, internamente, pela perda da hegemonia políticomilitar; externamente, pela debilidade e fraqueza internas que determinaram a subsunção do mundo grego ao domínio de impérios, os quais, paulatinamente, minaram sua autonomia, limitando vida e perspectiva. Remontemos, pois, aos atributos do mundo

\footnotetext{
7. K. MARX, F. ENGELS, L’ idéologie allemande, in: Oeuvres, III, philosophie, p.1056-7.
} 
helênico nos tempos clássicos. Em caracterização ampla, Austin e Vidal-Naquet, dispõem:

\begin{abstract}
A história da cidade grega é, poderia dizer-se, a história de um ideal impossível que quase nunca foi realizado, a não ser imperfeitamente e por um curto período. A cidade visava assegurar a existência dos seus membros. Supunha para isso a concórdia entre os cidadãos (e a ausência de desigualdades econômicas demasiado grandes), a autarcia econômica e a independência política e militar. Entre o ideal e a realidade houve freqüentemente, mesmo na época clássica, uma certa distância. O equilíbrio interno era freqüentemente rompido por conflitos sociais e políticos, a autarcia econômica era difícil de se realizar plenamente, sobretudo para as cidades mais importantes, nomeadamente para o trigo e os metais, e a autonomia política era regularmente ameaçada, não só por potências estrangeiras (a Pérsia, a Macedônia), mas por outras cidades gregas com ambições hegemônicas, como Atenas no século V. No século IV, a distância entre o ideal e a realidade vai se tornando maior ${ }^{8}$.
\end{abstract}

A citação acima, já presente na Introdução, é clara, demarcando de modo substancial a realidade histórica intrinsecamente problemática da qual emerge o ideário aristotélico, realidade posta na agudez das desigualdades e insuficiências. Distinga-se, nesse sentido, e em primeiro plano, o conflito e a fragilidade da vida in communitas: a guerra endêmica invadia e se espalhava como modo de vida, como instrumento a enfrentar as debilidades e dilemas da vida citadina. Conflitos armados, não raros, que visavam sustentar as rotas comerciais do trigo, deste modo, assegurando certa autarquia, dinâmica guerreira que expunha, de pronto, a fragilidade ingênita da vida citadina grega, pois o que está pressuposto é a inexistência de condições materiais de produção a garantir a ordem societária. A luta cotidiana das cidades era a luta para proporcionar condições de alimento para os cidadãos. Inexistia qualquer garantia em relação ao abastecimento regular de trigo para as cidades, e a guerra, assim, comparecia como meio de garantir a reprodução social, a reprodutibilidade in communitas. Por outro lado, como assinala Y. Garlan, a guerra se põe como disposição a intervir na ordem e regulação societárias no sentido, ainda, da aquisição de bens e de escravos. E, em termos claros, afirma que para

o nosso propósito basta sublinhar - o que é incontestável - que a aquisição de alimento, de riquezas ou de escravos raramente foi apresentada pelos escritores antigos como a causa determinante de uma ou outra guerra em particular; só é feita menção - mas com freqüência - ao

\footnotetext{
${ }^{8}$. M. AUSTIN e P.VIDAL-NAQUET, Economia e sociedade na Grécia antiga, p. 131.
} 
número de vantagens que cabem aos vencedores em virtude de uma 'lei' de alcance muito geral que os autorizava, salvo estipulações contrárias, a dispor como entendessem dos bens e da pessoa dos vencidos. ${ }^{9}$

Garlan, portanto, indica o cerne motivador da guerra: o equilíbrio material reposto da comunidade. A disposição legal que envolvia os vencidos e a lei que permitia dispor de seus bens e de sua pessoa são provas irrefutáveis de que as guerras irrompiam na comunidade como movimento de conquista ou reposição de carências necessárias ou mesmo vitais em determinado momento. Faz-se nítido que a guerra recompunha a vida in communitas, o reencontro de ponto medial, quer dizer, a guerra era atributo comunitário na exata medida em que, por sua mediação, a escassez de bens e de escravos era superada, regulando-se as adstringências ingênitas. Deste modo, a pólis encontrava sua face guerreira, aguerrida pelas exigências que se coadunavam na tarefa que urgia no sentido de preservar e equilibrar a vida da cidade-estado. Por isso, o valor da guerra não era outro senão o de suprir necessidades incontornáveis, encontrar o ponto médio que assegurasse a perpetuação da comunidade.

E se assim o é, cabe sublinhar que a guerra, instrumento regulador, teve papel fundamental na instauração e preservação do império ateniense, produzindo as condições de seu apogeu. O século $\mathrm{V}$ marca, para Atenas e o mundo grego, a intensificação da luta militar e política; efetivamente, pelos próximos 150 anos, a guerra será realidade cotidiana. Das invasões persas até a morte de Aristóteles, em 322, a ação bélica se situa como centro das preocupações e atividades da cidade-estado. A derrota dos persas, nos anos 470, significa a ascensão definitiva da pólis ateniense no cenário geopolítico grego, Atenas se alça à condição de liderança político-militar do mundo helênico. Assiste-se, ora, a um processo de emergência de condições sócio-históricas que promove a expansão e fortalecimento da hegemonia ateniense. De um lado, então, temos a formação e a consolidação da Liga de Delos (nascida da luta contra os persas) cujo objetivo inicial estava na defesa e integridade do território helênico. Ciro Flamarion Cardoso, no ensaio A cidade-estado antiga, esclarece:

\footnotetext{
Ainda no decorrer da guerra contra os persas, em 476 a.C., Atenas conseguiu formar à sua volta uma liga marítima com a finalidade de libertar as cidades gregas da Ásia Menor, ainda sob o jugo do império persa - o que foi conseguido em 449 a.C -, e atacar e pilhar este último em represália pelas guerras médicas. A associação, cujo tesouro comum ficaria depositado na ilha de
}

\footnotetext{
9. Y. GARLAN, Guerra e economia na Grécia antiga, p.32.
} 
Delos, centro religioso dos jônios do Egeu, é conhecida como Liga de Delos. Dela participavam a maior parte das ilhas Cíclades, a ilha Eubéia, algumas das ilhas costeiras da Ásia Menor, partes das costas da Trácia e do Mar de Mármara. As cidades maiores contribuiriam com barcos de guerra, as menores com dinheiro. Atenas teria o comando, mas no Conselho da liga cada cidade disporia de um voto. Tratava-se, no início, de uma simaquia, cujo nome oficial era: 'os atenienses e seus aliados’. Com o tempo, porém, a Liga de Delos se transformou em um império marítimo submetido a Atenas. Esta passou a castigar as cidades que tentassem abandonar a aliança, o tesouro comum foi transferido para Atenas (454 a.C), onde passou a ser usado em despesas da própria pólis ateniense e não da liga, o Conselho desta desapareceu e colônias (clerúquias) de atenienses que conservavam sua cidadania de origem foram criadas em territórios vazios ou em terras confiscadas aos insurretos, para vigilância do império. ${ }^{10}$

Flamarion, como se conclui, observa que a formação e desenvolvimento do império ateniense se atam às condições de sobrevivência, de sustentação e manutenção da cidade-estado, que se articula em liga para se defender dos constantes ataques externos sofridos. As razões que levam à formação do império ateniense, nesse contexto, são de ordem prático-objetivas, pois nascidas de um cotidiano de poucos recursos e escassez de toda ordem: o que estava em jogo não era o incremento e desenvolvimento das forças produtivas, nem mesmo a difusão do comércio ou da manufatura; mas, diante de um quadro de insuficiências crônicas, de recursos limitados, a manutenção da unidade realizada pelo império ateniense que permitia tão somente a defesa e preservação do território, viabilizando, concomitantemente, por meios militares, o saque e a pilhagem, é que, de modo direto, ampliavam de forma significativa suas condições econômicas.

Por outro lado, o império ateniense, que em seu auge continha cerca de 150 cidades, acabaria por tecer uma convivência tensa com as cidades, numa hegemonia político-militar que imporia aos estados-súditos uma taxação em favor de seus cofres. De sorte que Atenas engendraria um modo de equilíbrio econômico (e, por extensão, comunitário) a partir de expedientes extra-econômicos, isto é, a imposição de impostos e a transferência (para Atenas) do tesouro da liga financiaram a grandeza cultural e cívica da pólis ateniense, lógica que significou a subsunção da Hélade ao modo de vida da mais rica e exuberante cidade clássica. Cabe dizer que o império ateniense criou mecanismos de reprodução extra-econômicos, ou independentes da esfera da produção, apartados de toda e qualquer modernização das forças produtivas, movimento posto pela

\footnotetext{
${ }^{10}$. Ciro Flamarion CARDOSO, A cidade-estado antiga, p. 37.
} 
expropriação de terras que assim consolidava e facultava não apenas a extensão da cidadania (a universalização do regime democrático), mas, de pronto, proporcionava enorme concentração da propriedade fundiária, de riquezas nas mãos de uma única cidade. Em outros termos, a cidadania ateniense ultrapassava a esfera local, citadina, tornando-se condição sine qua non do império ateniense, de sua pujança e de seu esplendor. O escravo-mercadoria tornava-se a forma mais plena e acabada do trabalhador cativo, ou seja, a concentração (sem precedentes) da propriedade fundiária demandou esta "nova” mão-de-obra, que poderia ser vendida e usada sem quaisquer restrições. Procedimento que se converteu na expressão universal do trabalho escravo, comprado e vendido para uso nas diversas cidades controladas por Atenas.

Não obstante a expansão produzida pela guerra, a pujança da Atenas do século V viria, progressivamente, a se enfraquecer. A guerra do Peloponeso e o fim do império ateniense minariam, em boa medida, sua orgânica e possibilidades. Em relação à guerra do Peloponeso, Flamarion afirma:

\begin{abstract}
A longa Guerra do Peloponeso caracterizara-se pela freqüência com que os campos dos inimigos eram devastados, as colheitas queimadas, as árvores cortadas. A propriedade, muito parcelada, tendeu a se concentrar: especuladores compravam as terras arruinadas a baixo preço, seja para recuperá-las e revendê-las, seja para praticar uma agricultura de exportação com mão-de-obra escrava. ${ }^{11}$
\end{abstract}

De fato, a referida guerra demarca, historicamente, o fim da hegemonia ateniense, assinalando uma existência prospectiva difícil e de crescentes inviabilidades. Se a guerra é vital para o equilíbrio da vida em comunidade, seu excesso, por outro lado, desequilibra e põe em perigo a própria vida in communitas; pois, em última instância, nunca se sabe, ou pelo menos é muito difícil determinar, a priori, vencedores e vencidos. Em verdade, a guerra do Peloponeso, a princípio, pelo poderio militar, deveria ter sido vencida por Atenas, de sorte que a derrota ateniense mudou dramaticamente o quadro geopolítico do território grego. Sua hegemonia se viu abalada, e para sempre perdida, a não ser por períodos intermitentes, efetivando-se apenas como uma pálida sombra do que fora em seu apogeu. Processo de afecção que implicou desordem econômica, não apenas ateniense, que se consubstanciou enquanto devastação dos campos, e que, concomitantemente, configurou a emergência de um novo cenário, a

\footnotetext{
${ }^{11}$. Ciro Flamarion CARDOSO, A cidade-estado antiga, p. 38-9.
} 
saber: o da especulação e do uso financeiro das terras. Como conseqüência, as cidades se enfraquecem e Atenas vê-se obrigada, uma vez mais, a lançar mão de recursos extraeconômicos para reduzir os desequilíbrios provindos da guerra. Glotz, em La cité grecque, afigura a crueza da situação ateniense nos pródromos do século IV:

\begin{abstract}
Aos atenienses do século IV repugnava ainda mais o dever fiscal. A história financeira dessa época apresenta, com efeito, um espetáculo singular. O Estado, que as guerras perpétuas reduzem a uma perpétua penúria, esforça-se por encontrar novas fontes: ele dobra os impostos indiretos, o centésimo sobre importação e exportação, o centésimo sobre as vendas imobiliárias; ele recorre o mais freqüentemente possível à contribuição extraordinária de guerra, de modo a torná-la quase uma contribuição comum; ele organiza a trierarquia de modo a converter uma prestação em um imposto direto; ele apela às contribuições voluntárias; em desespero de causa, ele multiplica os confiscos e encarrega os generais de alimentar a guerra às expensas do país inimigo ou mesmo amigo. ${ }^{12}$
\end{abstract}

Glotz, apresenta uma Atenas combalida, refém de suas próprias inviabilidades, de guerras intermináveis que acabariam por minar sua estrutura. Em outras palavras, o autor atesta a presença marcante de mecanismos extra-econômicos a regular os Estados, porque os excessivos gastos militares e a devastação dos campos obrigaram a pólis ateniense do século IV a recorrer a impostos extraordinários como forma de repor, minimamente, os recursos necessários à sua auto-regulação, buscando o reencontro do ponto medial perdido em função de décadas de guerras. Verifica-se que o século IV acabaria por impor aos cidadãos uma situação fiscal que, no século anterior, seria impensável. Enquanto o cidadão do século V se dispunha voluntariamente a gastar quantias elevadas com festividades cívicas; no século IV, ao arrepio das tradições atenienses, o Estado, por sua situação de falência, impunha ao cidadão da mais desenvolvida cidade grega situações constrangedoras, tais como: a cobrança de tributos por meios impositivos, ou, até mesmo, a tributação de atividades econômicas que, em passado recente, eram desobrigadas de qualquer ônus.

Glotz, frise-se, afigura os termos de uma pólis decaída, abalada por guerras e assombrada pela ausência de recursos para fazer valer as atividades comunitárias. Em suma, o século IV foi testemunha de um exaurir lento e progressivo, não apenas da economia, mas do espírito cívico ateniense, pois a relação Estado-cidadão tornou-se tensa, desequilibrada, desmedida, sob os influxos de um tecido social que se esgarçava.

12. G. GLOTZ, La cité grecque, p. 400-1. 
Declínio do espírito cívico corporificado na assimetria que se instaurava, paulatinamente, “entre o poder público e os direitos do indivíduo”. ${ }^{13}$ Emerge, de pronto, a figura de um cidadão bem mais preocupado com os direitos privados, porque a segurança, mesmo parcial, que o Estado lhe proporcionava desaparecera, postos os conflitos bélicos e um cotidiano em desequilíbrio. Em fórmula sintética, o autor de $L a$ cité grecque expõe o problema: trata-se de "uma crise no casamento" e da instauração do "reino das cortesãs”. ${ }^{14}$ Glotz reconhece uma desagregação no seio das famílias e da própria comunidade, situação contraposta aos tempos áureos de Atenas. De fato, e desdobrando a questão, o autor defende a idéia de que o declínio da pólis, no século IV, engendrou uma fissura específica, nunca antes observada: para o homem do século IV, o casamento deixa de ter o peso e a relevância como ritual capaz de criar uma comunhão entre um homem e uma mulher; logo, e isto é decisivo, deixa de ser compreendido como elo importante a ser estabelecido entre as diversas gerações, o que significa que o ritual pelo qual as famílias transmitiam, obrigatoriamente, aquilo que "tinham recebido em tradição dos ancestrais" 15 é rompido, ruptura que emerge do esgarçar das relações sociais, vale dizer, da mediania comunitária. Nesse sentido, o concubinato, que no século $\mathrm{V}$ era apenas tolerado em função do nascimento de crianças livres "no caso de casamentos estéreis"16, no século IV era prática comum, que desagregava tradições, pois proclamava-se: “Nós precisamos de esposas para perpetuar nosso nome, de concubinas para cuidar de nós, de cortesãs para nos divertir". ${ }^{17}$ Por este motivo se o casamento se insere, ou pelo mesmo se inseria, no movimento cívico de perpetuar tradições, em especial a do nome familiar que permitia a inserção do indivíduo na vida militar e política - pertencer à determinada fratria significava ser reconhecido (no caso dos homens) como cidadão apto a exercer determinadas funções e exercitá-las no seio da vida citadina -, esta situação se altera, perdendo-se gradativamente. Desagregação do tecido social, das relações familiares que implicaria, e não poderia ser diverso, grave crise da comunidade.

Por outro lado, e concomitantemente, o agravamento da situação econômica em função da devastação dos campos comprometeria, no mais das vezes, a tradição familiar da herança, na exata medida em que as famílias tiveram seu patrimônio reduzido.

\footnotetext{
${ }^{13}$. G. GLOTZ, La cité grecque, p. 345.

${ }^{14}$. Cf. GLOTZ, G., La cite grecque, p. 345.

${ }^{15}$. Cf. GLOTZ, G, op. cit., p. 346.

${ }^{16}$. Ibid., p. 346.

${ }^{17}$. Ibid.,, p. 346.
} 
Destarte, a herança, passada de geração em geração, torna-se, igualmente, incerta, com que se rompem tradições, continuidades e possibilidades; em suma, o justo meio citadino.

Outro aspecto socialmente desagregador, ressaltado por Glotz, diz respeito ao aparecimento e desenvolvimento (no século IV) de fortunas não fundiárias, ou aquelas oriundas do comércio, da ganância individuais. Aponta-se para o incremento de determinadas atividades, não ligadas à terra, que também forjaram riqueza. Para Glotz, ao longo do século IV, nenhuma profissão "escapa das garras do capitalismo, da crematística. A agricultura se mercantiliza a tal ponto que ocorre a evicção progressiva dos pequenos camponeses; concentrando, nas mesmas mãos, a grande propriedade”. ${ }^{18}$ Que a desagregação citadina no século IV promovesse a emergência, concentrada, de novas riquezas baseadas no comércio ou num certo incremento da propriedade, era movimento real, dadas as contradições vividas pela Grécia em geral. O que não assume rigor, na reflexão de Glotz, é caracterizar estas mudanças a partir de categorias que surgiriam dois mil anos depois, na época compreendida entre o fim da Idade Média e o início do Renascimento, quando se implementavam, lenta e gradualmente, as primeiras formas do capital mercantil. Equiparar modos específicos da crematística a procedimentos capitalistas é, no mínimo, perspectiva teórica ilusória, pois, diferentemente da lógica capitalista, a produção de mercadorias nunca se constituiu em ação ou prioridade no mundo antigo; antes, sua ordem se estruturava pela produção de valores de uso, e isto, de forma localizada e adstringida, posto o baixo desenvolvimento das forças produtivas. Do mesmo modo, o que significa afirmar que a agricultura se mercantilizava? Se assim tivesse se dado, teríamos, em primeiro lugar, a produção do campo tornada mercadoria; em segundo lugar, esta mercadoria teria encontrado tanto o mercado interno, como o mercado externo, o que jamais se deu, já que, como sublinhado, o império ateniense não se desenvolveu a partir do comércio, de fato; inversamente, Atenas subjugou cidades, impondo pilhagem e cobrança de taxas. Significa que nem nos tempos mais prósperos da época clássica a produção ganhou o feitio de mercadoria, porquanto jamais houvera desenvolvimento efetivo das forças produtivas que permitisse a emergência de um mercado grego ou entre impérios. No essencial, temos a troca de valores de uso, e, só excepcionalmente, de valores de troca.

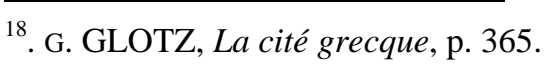


Assim sendo, o que de Glotz se deve tomar é a referência de mudanças no cenário econômico que expressam o transtorno de uma economia agrária, e, mediatamente, o desequilíbrio, a perda de limites e a desarmonia como condição ateniense em seu momento declinante.

Em tempos recentes, Edmond, no já citado Aristote. La politique des citoyens et la contingence, reflete sobre as causas do declínio grego, asseverando que o desequilíbrio perene do século IV é o próprio modus operandi da comunidade que, ao final, encontra o seu declínio. Edmond, nesse sentido, reconhece que, no século IV, a crematística atuava como forte fator desestabilizador da comunidade política. Melhor explicando, se, de início, a boa arte de enriquecer era afirmada e vivida pelo homem grego em sua forma positiva, porque vinculada à família e orientada para o consumo doméstico, vale dizer, a boa arte de enriquecer era aquela cujo objetivo visava suprir as necessidades da comunidade, não aspirando ao supérfluo ou ao enriquecimento pessoal $^{19}$, o declínio citadino, por sua vez, enforma a emergência de novas formas de enriquecimento, contrárias à natureza da comunidade, que acabariam por minar o já frágil equilíbrio in communitas. Tomando suas palavras:

\begin{abstract}
À necessidade se substitui o desejo desmesurado de adquirir, de trocar e de utilizar as riquezas sob o impulso da especulação monetária. A moeda se torna por si mesma uma riqueza e um objeto de troca, pois ela não tem mais relação a não ser consigo mesma. Ela permitiu a corrida para os lucros, além de todo limite. A crematística muda de sentido e se subordina à economia. Aristóteles acaba por estabelecer uma distinção entre as riquezas nascidas da aquisição de bens por uma economia familiar relativamente autônoma, no quadro das famílias agrícolas ainda reguladas pela natureza, e as riquezas nascidas do desenvolvimento da produção e do comércio, ligado àquele da especulação monetária /.../ Ela afeta a harmonia natural que mantinha juntas as famílias patriarcais agrícolas e a cidade. ${ }^{20}$
\end{abstract}

A reflexão, nota-se, afirma não apenas o aparecimento de um novo modo de aquisição de riquezas, mas também de um homem que vive para satisfazer seus desejos de modo imoderado, ilimitado. Deve-se, no entanto, tomar o devido cuidado teórico com a transposição de categorias atuais para explicar o passado: até que ponto podemos falar, em Atenas, de uma especulação monetária onde a moeda torna-se, por si mesma, a medida da riqueza e das trocas? Neste movimento não estaria subentendido o alçamento

19. Cf. EDMOND, Michel-Pierre, Aristote. La politique des citoyens et la contingence, p.39.

20. Michel-Pierre EDMOND, op. cit., p.39-40. 
da moeda à categoria de mercadoria universal? De fato, a emergência de determinadas fortunas não fundiárias, o desenvolvimento do comércio e da moeda, alteraram as condições de equilíbrio e a harmonia citadinas, o que não significa afirmar que estes processos se aproximam, como às vezes se subentende, de processos econômicos de tempos históricos modernos. É certo que os desequilíbrios crônicos da pólis ateniense criaram a possibilidade de uma extração e produção de riquezas não apenas atadas à terra, isto é, a campos devastados por guerras, incultiváveis, visto que alguns se lançaram ao comércio, até mesmo o da própria terra, a princípio inalienável. Situação, sinaliza Edmond, que necessariamente desequilibra a comunidade intrinsecamente adstrita cujos dilemas insolúveis acabariam por se impor definitivamente. Retomemos, para fins conclusivos, os argumentos históricos de Jean-Pierre Vernant, presentes em Mito e sociedade na Grécia antiga, em que se dispõe acerca da instabilidade ingênita que viria a consumir a vida in communitas a partir de fins do século V:

... por volta do fim século $\mathrm{V}$ se percebe toda uma série de transformações de conseqüências decisivas. Os campos haviam sido devastados pela guerra, as culturas e propriedades rurais abandonadas, enquanto que já se desenvolvia, na cidade, um meio propriamente urbano. A existência citadina contrasta desde então como gênero de vida, atividades profissionais e mentalidade, com as antigas tradições dos habitantes rurais. Ao mesmo tempo vê-se reaparecer, para responder às necessidades da guerra, o personagem do mercenário, impondo-se o chefe militar profissional. A terra, enfim, deixa de ser inalienável como no passado. ${ }^{21}$

Vernant, vê-se, destaca três pontos fundamentais: o desequilíbrio econômico advindo da devastação dos campos já em fins do século V, inclusive com o abandono de propriedades, com a perda, para muitas famílias, de suas condições de auto-subsistência, o que, implicava, inexoravelmente desequilíbrios estruturais; a oposição entre as atividades profissionais citadinas e a respectiva oposição entre as mentalidades; a possibilidade de compra e venda de terras e a condição do soldado mercenário. Em relação à venalidade da terra, frise-se seu peso e força no processo que esgarça a comunidade clássica. A terra, além de ser força produtiva essencial, constituía $a$ verdadeira e sagrada moradia dos antepassados, ou seja, a terra era o lugar onde as famílias enterravam os seus mortos e se sentiam ligados a eles. ${ }^{22}$ De sorte que as famílias, pela terra, perpetuavam as ligações com a comunidade, eternizando o nome e

21. Jean-Pierre VERNANT, Mito e sociedade na Grécia antiga, p.16.

22. Cf. COULANGES, de Fustel, A Cidade Antiga, p. 63-74. 
as tradições familiares, ou, e isto importa marcar, eternizando a comunidade. Então, a venalidade do solo desvirtua os mecanismos pelos quais a pólis grega alcançou relativa autarquia; a venda da propriedade da terra retira das famílias a segurança secular da produção de auto-subsistência, como também interfere diretamente na herança e regulação familiares, na reprodução das relações comunitárias. Nesse ponto, a vida citadina se desregula, pois a terra encontra na venalidade uma condição não comunitária. Ao tomar os argumentos das Formen, Vernant sintetiza o problema ao pontuar o desequilíbrio universal que envolveu as cidades gregas em cenário declinante, a saber:

Tais contradições só poderiam nascer nas condições próprias às cidades. Ao mesmo tempo, contudo, seu desenvolvimento põe em questão o próprio quadro no qual vieram à luz. Aos olhos de Marx, a generalização da escravatura, a extensão da trocas internas e do comércio marítimo, a constituição de um setor mercantil da produção e a concentração da propriedade fundiária desintegram as formas de propriedade do solo e as estruturas sócio-políticas que caracterizam a cidade como tal. ${ }^{23}$

Das palavras de Vernant se depreende o nível de desmedida vividos pelas cidades gregas, ou seja, Aristóteles, certamente, fora testemunha ocular de tais processos. Em Política, encontramos a célebre passagem em que condena, veementemente, a crematística da usura, o dinheiro que tem por objetivo único gerar mais e mais dinheiro. Decerto, a política e a ética em Aristóteles consubstanciam, no plano teórico, a intenção do autor em atuar e repor a medida e harmonia citadinas que, a cada dia, tornava-se mais distante e inalcançável. Daí, o apelo apaixonado e obsessivo do estagirita pela medida, pelo limite e mediania, ou melhor: para o autor da $E N$, o ideário político-ético - seria o único meio ou caminho para repor, em limites aceitáveis, a ordem e a convivência nas cidades-estado.

\section{A política e a ética: mecanismos de regulação comunitária.}

O olhar positivo e excessivamente complacente com que a política foi compreendida desde os gregos configura, in limine, problema maior no interior da

\footnotetext{
23. Jean-Pierre VERNANT, Mito e sociedade na Grécia antiga, p.12.
} 
tradição filosófica ocidental. Enaltecida, desde logo, positivamente tomada, a política se arma, enquanto meio civilizador, a demarcar as formas de sociabilidade e de racionalidade. A reflexão de Edmond testemunha e sintetiza o modo e o espírito com que a tradição ocidental reconheceu e determinou a política, predicado capital dos homens:

\begin{abstract}
A natureza política dos seres humanos designa aquilo graças a quê os homens podem mudar de estado e modificar o curso das coisas. A política é, por excelência, o domínio onde há movimento. Pode-se mesmo dizer que ela é, em si mesma, o grande movimento humano. Exprime concretamente; isso quer dizer que a política começa a partir do momento em que certas sociedades saem ou se liberam das oligarquias de todos os tipos que lhes imobilizavam. Com a formação de uma vida social com caráter político, a existência humana toma uma significação e um valor novos. Para Aristóteles, a natureza do homem é a política e a política é a contingência. $^{24}$
\end{abstract}

Edmond caracteriza a política como o ‘grande movimento humano’, que permite a mudança e a transformação no mundo dos homens. A política nasce como ruptura das formas de sociabilidades estanques (oligárquicas) em um movimento que as conduz a patamares mais humanos, racionais, de modo que se arrima e é reconhecida no solo da contingência, nas incertezas e nas transformações que fazem do mundo humano um universo não necessário, imprevisível. Assim, Edmond saúda a política como instrumento a interferir, precisamente, nesse espaço incerto e não previsível do homem político cuja única certeza é a de que o amanhã pode ser diferente. Ou ainda, a política comparece aos olhos da tradição ocidental enquanto instrumento positivo a mediar e viabilizar mudanças in communitas, assim como nas sociabilidades modernas, a partir das revoluções européias. Seja como for, e isto importa, a tradição ocidental identifica na política a forma pública da racionalidade, mediação resolvente dos dilemas e da desagregação impostos pelo desenvolvimento histórico da propriedade privada. Nesse sentido, utilizemos a palavra de Manfredo Araújo de Oliveira, em Ética e sociabilidade, que, ao analisar a política em Aristóteles, reconhece apenas seu tecido positivo:

A política enquanto teoria tem como conteúdo a auto-realização do ser racional e livre nas instituições éticas. A tarefa da pólis é justamente fazer com que os homens, em todas as suas

24. Michel-Pierre EDMOND, Aristote. La politique des citoyens et la contingence, p.10. 
instituições, cheguem à realização de si mesmos. Todo o fim da atividade política é a consecução de uma vida feliz, em acordo com a essência do homem. ${ }^{25}$

Ou, “o homem é essencialmente ordenado à vida política; ele, sem lei, nem direito, é o pior pensável, mais selvagem que o próprio animal. É o homem que se eleva à dignidade da política, que pode assumir seu 'destino' e orientar sua vida de modo digno". ${ }^{26}$ Palavras contundentes que atestam, de fato, e como proposto, um olhar unilateral, incapaz de reconhecer as mazelas próprias da política, já em seu nascimento.

Por outro lado, tome-se a referência de Norberto Bobbio (exemplo de um não helenista), - aqui tomado como um dos representantes contemporâneos mais importantes da reflexão política - no livro Teoria geral da Política em que descreve, sinteticamente, as preocupações mais comuns da reflexão política ocidental: de um lado, a “descrição, projeção, teorização da ótima república ou, se quisermos/.../a construção de um modelo ideal de Estado, fundado sobre alguns postulados éticos”; ${ }^{27}$ de outro, a "busca última do fundamento do poder, que permite responder à pergunta: A quem devo obedecer? E por que?”. ${ }^{28}$ Preocupações, pois, que se voltam para “a determinação do conceito geral de 'política', como atividade autônoma /.../que tem características específicas que a distinguem tanto da ética quanto da economia, ou do direito ou da religião" ${ }^{29}$ Delineada de forma sumaríssima, a demarcação de Bobbio se ata às considerações iniciais de Edmond, pois, formulando as inquietações mais urgentes da filosofia política ocidental, faz valer, positivamente, as indagações sobre as melhores formas de Estado, de sua relação com a ética, da autonomia da ciência política frente às demais ciências, da legitimidade do poder. Contrariamente, na letra e no espírito marxiano, José Chasin delineia o que a tradição ocidental reconhece positivamente na política: “o atributo da politicidade não só integra o que há de mais fundamental do ser humano-societário - é intrínseco a ele - mas tende a ser considerado como sua propriedade por excelência, a mais elevada, espiritualmente, ou a mais indispensável, pragmaticamente" ${ }^{30}$ Em outras palavras, a positividade da política é sua inerente condição civilizadora, perene e eterna - porque transformadora - na vida das

\footnotetext{
25. Manfredo Araújo de OLIVEIRA, Ética e sociabilidade, p.70.

26. Ibid., p.83.

27. Norberto BOBBIO, Teoria geral da Política, p.67.

${ }^{28}$. Ibid., p.68.

29 . Ibid., p.68.

30. José CHASIN, Estatuto ontológico e resolução metodológica, p. 368.
} 
sociabilidades. As considerações de W. Kullmann projetam esta grandeza que se reconhece, que é predicado humano-social. Afirma o helenista:

Ora, a política, por boas razões, é uma ciência prática, como resulta claramente da Ética a Nicômaco, I, 1, e da Metafísica, E, I. Ela busca, com efeito, efetuar um certo estado social e ela dá ao legislador ou ao homem político as indicações sobre a melhor forma de organizar o Estado. O objetivo que ela se propõe a atingir é, segundo a Ética a Nicômaco, I, 1, 1094b7, o bem humano. /.../ Ela também é chamada, na Ética a Nicômaco, X, 10, 1181 b 15, 'a filosofia das coisas humanas'. ${ }^{31}$

Kullmann, decerto, atribui à política dimensões essencialmente positivas enquanto instrumento a operar na esfera social da construção do bem humano, aparente generosidade helênica advinda de situação histórica em que a política é, necessariamente, meio ou instrumento a administrar as coisas humanas, pois o homem grego (como amplamente assinalado) é incapaz, por suas próprias energias, de regular a vida citadina dependendo, assim, da política e da ética como instrumentos de equilíbrio e de favorecimento da vida in communitas. Kullmann compreende a importância do nascimento da política, mas desconsidera o processo histórico que implicou negativamente o seu surgimento, vale dizer: a tentativa da pólis helênica em dar curso ao seu desenvolvimento auto-sustentado, a partir e exclusivamente de suas forças, o que mostrou-se, histórica e paulatinamente, inviável.

Ressalte-se, por outro lado, um conjunto de autores que reconhece, na construção racional de um logos que se fez público, o sentido e a identidade da política, sua capacidade de refletir e encontrar soluções. Nesse sentido, as palavras de Rüdiger Bubner confirmam este posicionamento:

A deliberação, a explicação e a crítica na comunicação intersubjetiva fazem parte dos constituintes do político, porque a comunidade humana de ação acabada resulta da unanimidade das intuições que dirigem a ação. O que nos reúne e nos aproxima na política é a unidade das orientações que dirigem nossa prática comum. Trata-se de recomeçar constantemente a fundar e a conservar essa unidade no meio do trabalho retórico do logos. No meio das modificações de circunstâncias e de situações políticas, deve-se garantir o bem como perspectiva da prática comum. $^{32}$

\footnotetext{
31. KULLMANN, W. L'image de l'homme dans la pensée politique d'Aristote in: Aristote politique. Etudes sur la Politique d'Aristote, p. 162.

32 . R. BUBNER, Langage et politique in: Aristote politique, p.355.
} 
Bubner encontra, na razão que se fez comunitária, a identidade que faz da política o meio adequado a perspectivar e a garantir o bem enquanto construção citadina. O logos político, é legítimo afirmar, compreende a primeira experiência humana de crítica e autocrítica, de valorização do espaço público conquanto espaço privilegiado da retórica que se exercita no convencimento do outro. Na democracia direta entre os gregos, ou na representação indireta da modernidade, não obstante, jamais encontrou resoluções autênticas às adversidades histórico-sociais, aos desequilíbrios imanentes às sociabilidades. Assim concebida, a razão pública (na figura positiva da política) é, no interior das muitas ilusões da humanidade, perversão práticoideológica, pois é duplamente impotente: ideal e praticamente. E de tal concepção, a Atenas aristotélica, como se buscou demonstrar no curso deste estudo, é exemplo vivo.

Barbara Cassin corrobora as palavras de Bubner ao distinguir e singularizar o homem, a partir de Aristóteles, por sua natureza política: o homem, o mais político dos animais gregários. As primeiras páginas da Política projetam o animal político em vista da vida in communitas, inseparável de um logos racional, politicamente persuasivo. Assinala a autora:

Constata-se que a superioridade, o “plus” político do homem, remete à diferença entre sons vocais e logos, mas que essa diferença, por sua vez, remete a uma outra diferença, aquela da extensão coberta pela sensação: os animais sentem o prazer e a dor, e suas vozes têm significado para eles, enquanto que os homens sentem o útil e o nocivo, ou o bem e o mal, o justo e o injusto etc., e isso é o que seu logos é capaz de mostrar. Essa simples diferença de extensão induz uma modificação de ordem, pois o “plus” político se torna o verdadeiramente político, em todo caso, o tema da Política. ${ }^{33}$

Cassin dispõe o político no fundamento da capacidade argumentativa da razão de expor sentimentos, idéias, juízos acerca da realidade, isto é, de expor-se na possibilidade da crítica e autocrítica, que tipifica o animal político, pois os demais animais gregários caminham por terreno não intersubjetivo, no qual o som não é linguagem, determinação de uma capacidade, de algo ou de alguma natureza essencial. Sem dúvida, o logos, distinção do animal político, que se faz retórico na vida citadina, forja, de algum modo ou em algum grau, o equilíbrio e o bem humanos. Contudo,

33 . Barbara CASSIN, Lógos et politique in: Aristote politique, p.373. 
Cassin não observa que o logos político é, ele mesmo, intrínseco às inviabilidades congênitas da cidade-estado e que, portanto, é incapaz de pôr a si mesmo como manifestação resolvente e decisiva dos influxos históricos da antiguidade clássica. Fica claro, de pronto, que a razão política - no que pese sua novidade e legitimidade históricas - foi e sempre será esse viés subjetivo, aparentemente brilhante e amesquinhado em suas possibilidades.

Vale ultimar as palavras do helenista alemão Theodor Gomperz (1832-1912) que, em sua ampla e densa história da filosofia antiga, mostra-se (como co-pertença da tradição ocidental) inteiramente a favor do juízo positivo acerca da política. O tomo III, dedicado a Aristóteles, abarca temas sobre a vida, a obra, a academia e os principais estudos do filósofo, voltados à ontologia, física, psicologia, ética, política e arte. Em capítulo dedicado ao Estado aristotélico, Gomperz afirma:

\footnotetext{
O Estado é criado em benefício da vida, subsistindo como um meio do 'bem viver'. Tal comunidade é um produto da natureza. De tal modo que o homem que não pertença a nenhum Estado, ou é um homem mau ou está acima do homem (super-homem). Comparado à abelha ou a qualquer outro animal gregário, o homem é um animal muito mais 'político'. Assim, como a natureza não realiza nada em vão/.../a simples voz que expressa as sensações de prazer e dor, no caso do homem, lhe outorga a linguagem que lhe permite distinguir o útil do prejudicial e, portanto, o justo do injusto. ${ }^{34}$
}

Gomperz entende o Estado grego como criação essencialmente generosa, que funda o bem viver ou o bem humano, como marcara Aristóteles já às primeiras linhas da EN. O helenista alemão, pois, ressalta a predicação ingênita dos homens enquanto animais políticos, muito mais que as abelhas ou de qualquer outro animal gregário. Assim, a comunidade política permitia aos homens, através da linguagem, a unidade e a comunhão de sentimentos para enfrentar os desafios postos pela vida in communitas, vale dizer: o que é útil ou nocivo, justo ou injusto, válido, adequado ou errado? Questionamentos que, na ordem do dia, consignavam aos homens as condições dos enfrentamentos da vida citadina. Gomperz sinaliza, unilateralmente, o melhor da política: a construção (nunca empreendida ou realizada) de um bem viver citadino harmônico e equilibrado. De fato, esta tarefa (que a própria política se imbuiu) sempre esteve distante de toda e qualquer realidade empírica, factível e humanamente possível.

\footnotetext{
34. Theodor GOMPERZ, Pensadores griegos: história de la filosofia de la antigüedad, p. 343.
} 
Desse modo, a tradição ocidental tomou essa direção parcial e unilateral. De nossa parte, a política e a ética em Aristóteles nasceram por outras razões, que não humanamente positivas (mesmo que elas existissem), mas, acima de tudo, a partir das inviabilidades genéticas da pólis grega; em síntese, pelas apoucadas condições sóciohistóricas, ou melhor, do incontornável amesquinhamento das forças produtivas materiais. A política e a ética aristotélicas enformaram a comunidade e o indivíduo, permitindo níveis de relativa autarquia citadina, de reprodução in communitas. Por isso, as razões que levaram ao nascimento da política foram, em essência, advindas de circunstâncias negativas, donde o clamor e o pendor pelo limite e medida são, inevitavelmente, a lógica e o modo de ser da cidade-estado grega. Uma vez mais, no arremate que sintetiza e vivifica esta argumentação, tomemos a afirmação de José Chasin:

\footnotetext{
Vista no conjunto real de sua entificação e reiteração, a comunidade antiga não manifesta apenas a dimensão fascinante das atividades individuais e gerais exercidas em cooperação no quadro de uma vida solidária, mas exibe no mesmo envoltório, e com a mesma ênfase, os contornos intrínsecos de sua fraqueza constitutiva. Trata-se, em verdade, de cooperação e solidariedade feitas de incipiência e debilidade, incapazes, eis o ponto crucial, de subsistir exclusivamente por si próprias/.../Pelos seus próprios limites ou insuficiências necessita de algo “externo”, para além dela, ou melhor - uma força extra - que a confirme e complete e com isso a viabilize enquanto aparato dinâmico de sustentação do ordenamento social. ${ }^{35}$
}

De imediato, o argumento reposto de José Chasin esclarece, sem dúvida, o mecanismo que engendrou a política e a ética aristotélicas enquanto meios de regular e impor limites a partir da "incipiência e debilidade” in communitas, de uma “cooperação e solidariedade" adstringidas, apoucada em suas possibilidades e finita em suas perspectivas. Em outros termos, a política que, aristotelicamente, era meio regulador, demandava coerção, a qual se fez condição de possibilidade da comunidade. Em suma, a política é força ativa que, antes do bem, promove a vida real, antes da comunhão, a unidade fragmentária que possibilita a vida em comunidade.

Do mesmo modo, a prioridade da ética sobre a política configura inversão e permissividade com que boa parte da tradição filosófica ocidental insistiu em compreender as categorias da política em Aristóteles. As linhas iniciais da EN situam $a$

35. José CHASIN, O Futuro Ausente, in: Ad hominem, Revista de Filosofia, Política e Ciência da História, p.169. 
política enquanto ciência prática a subordinar as demais ciências e, por este elo, encontrar o bem humano, ${ }^{36}$ quer dizer: o bem individual deve sujeitar-se à ordem comunitária. Em outras palavras, a ética deve-se sujeitar-se à política e não o inverso. Palavras singelas que ordenam a reflexão do filósofo em tela, ou seja, comparece - em primeiro plano - a ideação sobre a pólis, o primado da comunidade, a referência de que o bem citadino é maior e mais importante do que o bem individual. Assim, o livro V da EN atesta, com pertinência, estas formulações ao reconhecer a justiça como virtude ética essencial, pois essencialmente comunitária, seu objetivo era o bem de outrem; a justiça era caracterizada como justiça política, determinação ampla e fundamental; sua finalidade consistia em preservar, regular e equilibrar as possibilidades da vida in communitas; e, por último, comparece a formulação da justiça distributiva e corretiva, ou seja: voltadas, respectivamente, à distribuição eqüitativa de bens e do reparo às desproporções sofridas pelas ações entre indivíduos.

Quanto à Política, os primeiros livros voltam-se ao exame do desenvolvimento genético da pólis, de sua autarquia, da distinção do homem político, do senhor, do escravo, da boa e má arte da aquisição, em suma, da função e caracterização da família. É nítida, pois, a prioridade da comunidade (da política) sobre o indivíduo ou a ética. Ou seja, Aristóteles articulava o seu pensamento ético somente e a partir das necessidades citadinas e não o inverso: a ética não construía a comunidade; quem a construía era a política, ou ainda: a ética coadjuvava os homens a encontrarem o bem comum. Então, a política se armava no plano in communitas; a ética, por decorrência, era necessariamente secundária, a sua subordinação à política era sua própria condição de existência, pois a comunidade política era - e não poderia ser diferente - o foco central das preocupações aristotélicas, posto que a vida in communitas era o modus operandi da cidade grega e, portanto do “animal político”. Destarte, o indivíduo merecia apreço, mas em sua e decisiva relação carnal de co-pertença comunitária. Nesse aspecto, a ética era reconhecida em seu papel: educar o indivíduo, impor limites e regular a individualidade para a convivência na vida citadina.

Os Escritos de Filosofia IV revelam, o espaço ético atado à individualidade (Henrique. C. de Lima Vaz desconhece o primado da comunidade sobre o ethos) que se esforça em fazer o Bem. Vaz não questiona o porquê da imposição ética grega que se atava e condicionava à idéia do Bem, ou seja:

36. Cf. ARISTOTE, Éthique de Nicomaque, p. 21-3. 
... o "conhece-te a ti mesmo não era apenas uma injunção informal, a modo de um imperativo categórico. Na experiência de sua frágil condição de ser efêmero e falível, o homem grego tinha diante de si como metron e padrão um conjunto de atributos e fins que mediam a qualidade de excelência da práxis e desenhavam o perfil do "varão bom” (kaloskagathos) segundo o ideal ético-político da tradição/.../A intencionalidade profunda do agir orientado para o Bem implica justamente a autarqueia do sujeito ético, colocado em face da imprescritível tarefa de realizar o Bem na própria vida, como tarefa que só a ele pertence dentro do âmbito de 'cumprir o que é seu'. ${ }^{37}$

Em propositura diversa, Vaz entende a ética grega enquanto meio capaz de realizar a eudaimonia a partir de um ethos racional, deliberativo, mas não reconhece que este ethos racional finque raízes em solo social; a ética grega não advinha dos melhores sentimentos ou da generosidade de um povo, na exata medida em que conhecer os próprios limites e agir de acordo com a imposição racional era, para o povo helênico, necessidade imperiosa, de sobrevivência concreta. Ou ainda, Vaz denota a dimensão individual impositiva da ética, porém não aflora seu terreno histórico, a ligação e o encontro entre a vida citadina e a concepção ética, iniciada por Sócrates. De modo que o conhece-te a ti mesmo era muito mais a necessidade do homem grego de conhecer os seus limites para atuar comunalmente, adequar-se, preservar o modus operandi da cidade-estado, do que a consciência, isolada, de um dever a cumprir a partir de valores humanamente constituídos. De forma que Vaz atribui a Platão o primeiro grande esforço ético por impor limites às ações individuais, ao afirmar:

A idéia diretriz do pensamento ético de Platão, na qual se entrecruzam a significação ética e a significação metafísica, é a idéia de ordem (taxis). É ela que permite a unificação, sob a égide da teoria das Idéias, da Ética, da Política e da Cosmologia, assegurando a justa medida da arete ao indivíduo e à cidade e guiando o Demiurgo na construção de um kosmos harmonioso/.../A ordem irá assegurar assim a unidade das partes na constituição do todo, consistindo, pois, a ordem a cumprir cada uma das partes o que lhe é próprio (ta eautou prattein), de sorte que no todo assim ordenado possa transluzir a presença do Bem. ${ }^{38}$

É curioso, nesse sentido, que o capítulo dedicado à ética aristotélica não inclua nenhuma determinação acerca do limite, da mediania ou instituição da ordem. Talvez, a

37. Henrique C. de LIMA VAZ, Escritos de Filosofia IV, p.87.

38 . Henrique C. de LIMA VAZ, Escritos de Filosofia IV, p. 98-101. 
explicação resida no fato de que Vaz considere o aristotelismo um platonismo original, reformador e fecundo:

... mesmo sem levarmos em conta a riqueza e profundidade do pensamento ético de Platão que acabamos de percorrer em suas grandes linhas, a Ética aristotélica não pode ser pensada historicamente fora de sua essencial dependência da Ética platônica. Aristóteles viveu vinte anos na Academia, primeiramente como aluno, depois como professor e familiarizou-se profundamente com o modelo ali seguido e com o ensinamento platônico. A postura crítica mais tarde adotada por ele em face da herança doutrinal que recebera só pode ser compreendida a partir de seu conhecimento do platonismo original. Essa observação vale particularmente para o caso da Ética, pois é historicamente incontestável que o pensamento ético de Aristóteles situa-se no prolongamento da ética socrático-platônica e dela receba os grandes temas e problemas que seu gênio repensará numa perspectiva original. Todas as grandes categorias que formarão o arcabouço teórico do ensinamento ético de Aristóteles mostram, de uma maneira ou de outra, uma raiz platônica, e é dentro da tradição doutrinal originada em Platão, continuada na Primeira Academia e perpetuada na cultura ocidental sob o nome de platonismo, que Aristóteles deve ser situado. Ele representa, porém, uma versão tão poderosa e criadora do platonismo original que vem a inaugurar uma nova tradição - o aristotelismo - inconfundivelmente distinta mas não definitivamente arrancada do tronco platônico. ${ }^{39}$

Vaz, não obstante o reconhecimento da originalidade do aristotelismo, situa-o em coração platônico, no interior da herança dos grandes temas e da influência intelectual de seu mestre. De nossa parte, sublinhamos que o aristotelismo (mesmo sob os influxos decisivos de Platão) não deve ser colhido nos interstícios de um platonismo, reformado ou não, postas as rupturas decisivas com este ideário e isso nos mais variados campos e categorias. Tome-se, a título de concreção imediata, o rompimento e crítica da Idéia como ser e arquétipo. A EN recusa a Idéia platônica do Bem ético ao reposicionar o problema, a saber, o Bem passa a ser o Bem possível, empiricamente posto e necessariamente flexível. Isto é, o Bem adquire primado sensível, sendo avaliado e legitimado (ou não) em função das mais distintas variáveis, que o circundam, Bem, assim, que é passível de prospectiva in communitas. Nesse sentido, pode-se afirmar (embora divergências a este respeito existam nas diversas interpretações dos comentadores) que o estagirita situava a ética no plano do particular, como assinala Marco Zingano no artigo Particularismo e Universalismo na Ética Aristotélica:

39. Ibid., p. 109-10. 
Haveria assim, certamente, um modo correto de agir para cada situação, mas não haveria leis que determinariam previamente o que fazer. A ética aristotélica foi assim sentida como introduzindo um ar fresco nos sistemas morais rígidos, fundados em cânones a seguir, cuja expressão máxima se encontraria na noção kantiana de dever. No lugar de mandamentos ou leis a serem seguidas quase religiosamente, a ética aristotélica organizar-se-ia em torno de duas teses mais flexíveis e estritamente ligadas, (i) a da prioridade da percepção moral em relação à regra moral e (ii) a das circunstâncias com valor moral que não se deixaram apreender completamente por generalizações. Estas duas teses constituem o que se pode chamar de núcleo duro da recente atribuição a Aristóteles de um ponto de vista particularista em ética. ${ }^{40}$

Zingano, ao situar a ética no particular, corrobora centralmente nossas considerações, nos quais a ética se tece na análise das circunstâncias, o que significa que a ação individual ganha limites adequados, vincados às possibilidades da vida citadina e da boa convivência entre cidadãos. Na ética aristotélica, pois, a análise do particular era dimensão primeira, particularização a partir da qual se estruturava a boa conduta, voltada para e no interior dos parâmetros da comunidade. Do mesmo modo, José Arthur Giannotti, no artigo $O$ amigo e o benfeitor, examina a ética do benfeitor nas $E E$ e $E N$. Exame que se realiza a partir das categorias da magnificência e magnanimidade, com o que Giannotti denota a existência de uma ética centrada no particular, porquanto as disposições da magnificência e da magnanimidade operam a partir e no interior de situações concretas, objetivas. Particularidade ética que significa, frise-se, adequação individual ao convívio comunitário, limitando a ação dos indivíduos. De fato, Giannotti conclui que tais disposições interferem positivamente na regulação e ordem citadinas, quando declara que:

... a generosidade diz respeito ao dispêndio da riqueza. Mas numa escala muito maior e com uma estratégia peculiar. Como o próprio nome sugere, nos lembra Aristóteles, a magnificência implica dispêndio ajustado/.../ à larga escala/.../ de sorte que o agente se comporta como um cientista observando a quantia certa e, a despeito de gastar com grandeza, o faz de modo adequado. Em suma, possui a medida de suas doações, sabendo perfeitamente que, para receber as honras que lhe são devidas em troca, deve orientá-las para a comunidade e para os deuses na proporção correta. ${ }^{41}$

\footnotetext{
40. Marco ZINGANO, Particularismo e universalismo na Ética aristotélica, Revista Analytica: A ética de Aristóteles e o destino da ontologia, p. 76.

41. GIANNOTTI, José Arthur, O amigo e o benfeitor . Revista Analytica: A ética de Aristóteles e o destino da ontologia, p. 172.
} 
Especificando, a magnificência regulava a ordem in communitas porque permitia ao cidadão dispor de bens volumosos na proporção adequada e com fins comunais, o que significa, e numa proposição genérica, "se tece uma forma de sociabilidade que, ao contrário daquele equilíbrio constituído pelo mercado, constrói um sistema dinâmico de compensação, que tem no horizonte a amizade como prática da eudaimonía e identificação do eu pelo outro e no outro". ${ }^{42}$ Giannotti depreende da prática da magnificência um modus operandi da pólis grega capaz de gerar a compensação e equilíbrio para a vida citadina que, na raiz, era descompensada. De fato, a amizade que se expressava na benfeitoria era amizade in communitas, ou seja, ao cidadão rico era imposta a benfeitoria como forma de equilibrar, regular e estimular o espírito cívico; em face disso, a amizade cumpria, a seu modo, os laços que permitiam a coexistência comunitária, o valor que mantinha e unificava os cidadãos e as cidades.

Por fim, desenhado todo este contexto de limites comunitários e de suas implicações político-éticas, importa aludir que a ênfase e preocupação gregas com a ética denotam, in limine, a debilidade da política, do Estado, e uma forma de contornar os desequilíbrios. Se a política não conseguia ser socialmente resolutiva, ou mostrava suas próprias deficiências, então a ética era chamada a reforçar a institucionalização ideal do limite, do justo meio termo que se devia eticamente seguir. De fato, e generalizando a questão, o aparecimento da propriedade privada gerou e expôs cisões e fissuras que fragmentaram, na base, as formações sociais. Da propriedade privada emergiu a cisão entre proprietários e não proprietários. Então, como equilibrar o que é intrinsecamente desequilibrado? Se assim o é, a política configura, irremediavelmente, o cântico da impossibilidade, pois sua existência é a da busca de uma unidade num tecido de fissura ingênita, fissura que pela força da política, em verdade, é assegurada. A ética, por seu turno, foi e é vista na tradição histórica ocidental como meio civilizador da política, que, porém, não pode ser civilizada na essência, pois a política se articula a partir dos contrastes operados pela propriedade privada. Não obstante, a incivilidade da política é tomada, dominantemente pela tradição filosófica ocidental, enquanto fenômeno extrínseco e contraposto à própria política; em outras palavras, seus limites ou impossibilidades não são vistos como inerentes, mas nascidos daqueles que a efetivam, que exercitam e operam o poder, isto é, são entendidos como inadequação ética no mando político. Seja como for, o Estado, desde o seu nascedouro, já se mostrou

\footnotetext{
42. Ibid., p.174.
} 
impotente. Tome-se, como exemplo de novo, a emblemática passagem do livro III da Política [1278 b e 1279 a], na qual Aristóteles, em tom desesperançado, alude ao modo como a coisa pública passara a ser tratada em sua época:

\begin{abstract}
No que concerne aos encargos políticos, quando o Estado é fundado sobre a igualdade, quer dizer, sobre a similitude dos cidadãos, estes estimam justo exercer a autoridade cada um a sua vez; numa época antiga, como é natural, eles consideravam justo desincumbir-se de sua função à sua vez e cada um pensava que, em retribuição, qualquer outro velaria pelo próprio bem daquele, assim como ele mesmo anteriormente, durante seu encargo, velou pelo interesse desse último. Atualmente, porém, por causa das vantagens que se retiram da fortuna pública e do exercício das magistraturas, os homens desejam manter continuamente seus encargos, como se o poder mantivesse perpetuamente "em boa forma” os governos, por mais doentios que fossem; se esse fosse o caso, é sem dúvida assim que os magistrados “corriam atrás dos postos”. ${ }^{4}$
\end{abstract}

Uma ironia perpassa o texto aristotélico, bem como as lembranças de velhos tempos nos quais os cargos eram exercidos em prol da vida citadina. Já em sua época, pois, importa assinalar, advertia: as vantagens adquiridas a partir da fortuna pública acabariam por corromper os magistrados, em sua luta mesquinha por cargos e por sua perpetuação nos mesmos. Aristóteles, portanto, conquanto a tomasse como instrumento positivo, entrevira, mesmo que em traços abstratos, a inevitável corrupção inerente à política, efetividade que a constitui intestinamente. O que não poderia antever, porque historicamente impossível, é que a corrupção avistada não é de talhe individual, pessoal e ético; mas, ao revés, atributo intestino e inseparável, endêmico, como a história demonstraria. Mesmo assim, o estagirita percebera que algo não ia bem e que, nesse sentido, demandava esforços ainda maiores da ética, não obstante sua enorme impotência.

O final, ora atingido, imbrica um arco determinativo crítico-exegético entre a palavra de Aristóteles e a história ateniense. Fica, portanto, a certeza de que nosso trabalho alcançou, ao menos, a estatura de uma hipótese plausível, conquanto divergente das vias teóricas que marcaram a tradição filosófica ocidental, isto é, a política como positividade. Dessa maneira, a política, para os gregos, embora entendida como instância que ordenava a vida in communitas, era limite; limite ideal que respondia a um limite real, força coerciva que atendia a uma coerção da vida comunitária, ou seja, do

43. ARISTOTE, Politique, p. 66-7. 
justo termo médio, de que se faz política, ética, vida real. Em suma: que adstringe porque adstrito era o movimento histórico-social do qual emergiu. 


\section{Bibliografia}

ANDERSON, P. Passagens da antiguidade ao feudalismo. 2. ed. Tradução Telma Costa. Porto: Afrontamento. 1982. 326 p.

ARISTOTE. Politique. Paris: Les Belles Lettres. 1960. livres I-II. 174 p.

. Organização e tradução Jean Aubonnet. Paris: Les Belles Lettres. 1989. tome II. livres III-IV. 333 p.

. Organização e tradução Jean Aubonnet. Paris: Les Belles Lettres. 1989. tome II. livres V-VI. 315 p.

tome III. livre VII. 334 p.

Organização e tradução Jean Aubonnet. Paris: Les Belles Lettres. 1986.

. Organização e tradução Jean Aubonnet. Paris: Les Belles Lettres. 1989. tome III. Livre VIII. 438 p.

Éthique de Nicomaque. Tradução, prefácio e notas de Jean Voilquin. Paris: GFFlammarion. 1992. 346 p.

Éthique à Eudème. Introdução, tradução e notas de Vianney Décarie. Paris: Librairie Philosophique J. Vrin. 1997. 236 p.

ARISTOTLE. The Works of Aristotle. In: Great books of the western world. Organização W. D. Ross. USA: Encyclopaedia Britannica. 1952. v. I-II. tomes 8-9. 726 p. 699 p.

ARISTOTELES. Obras. 2. ed. Tradução do grego, estudo preliminar e notas de Francisco de P. Samaranch. Madrid: Aguilar. 1973. 1634 p.

ARISTÓTELES. Metafísica. Introdução, tradução e comentários de Giovanni Reale. São Paulo: Loyola. 2001-2. v. I-II. 341 p. 695 p.

A Constituição de Atenas. Tradução e comentários de Francisco Murari Pires. São Paulo: Hucitec. 1995. 276 p.

ARNAOUTOGLOU, I. Leis da Grécia antiga. Tradução Ordep Trindade Serra e Rosiléa Pizarro Carnelós. São Paulo: Odysseus. 2003. 188 p.

AUBENQUE, P. A prudência em Aristóteles. Tradução Marisa Lopes. São Paulo: Discurso editorial. 2003. $352 \mathrm{p}$.

$532 \mathrm{p}$.

El problema del ser en Aristóteles. Tradução Vidal Peña. Madrid: Taurus. 1984.

Aristote politique: études sur la Politique d'Aristote. France: PUF. 1993. 550 p.

AUSTIN, M; VIDAL-NAQUET, P. Economia e sociedade na Grécia antiga. Tradução António Gonçalves e António Nabarrete. Lisboa: Edições 70. 1986. 363 p. 
BOBBIO, N. Teoria geral da política. Tradução Daniela Beccaccia Versiani. Rio de Janeiro: Campus. 2000. 717 p.

BODÉÜS, R. Le philosophe et la cité. Paris: Les Belles Lettres. 1982. 264 p.

CARDOSO, Ciro. F.S. A cidade-estado antiga. 4. ed. São Paulo: Ática. 1993. 95 p.

CHASIN, J. O futuro ausente. In: Revista Ad Hominem. Santo André: Estudos e edições ad hominem. 2000. tomo IV. 243 p.

Marx - Estatuto ontológico e resolução metodológica. in: Pensando com Marx, São Paulo: Ensaio. 1995. 537 p.

CHAUÍ, M. Introdução à história da filosofia: dos pré-socráticos a Aristóteles, 2. ed. São Paulo: Companhia das Letras. 2002. 539 p.

CLOCHÉ, P. La démocratie athénienne. Paris: PUF. 1951. 430 p.

COULANGES, F. de. A cidade antiga. Tradução Fernando de Aguiar. São Paulo: Martins Fontes/UnB. 1981. 479 p.

CROISET, M. La civilisation de la Grèce antique. Paris: Payot. 1932. 349 p.

CROIX, G.E.M. de STE. La lucha de clases en el mundo griego antiguo. Tradução Teófilo de Lozoya. Barcelona: Crítica. 1988. 851 p.

EDMOND, M-P. Aristote. La politique des citoyens et la contingence. Paris: Payot \& Rivages. 2000. 190 p.

EHRENBERG, V. L'état grec: la cité - l'état fédéral - la monarchie hellénistique. Tradução Claire Picavet-Roos. Paris: François Maspero. 1976. 413 p.

FINLEY, M.I. Economia e sociedade na Grécia antiga. Tradução Marylene Pinto Michael. São Paulo: Martins Fontes. 1989. 337 p.

- A economia antiga. 2. ed. Tradução Luísa Feijó e Carlos Leite. Porto: Afrontamento. 1986. 291 p.

. Os gregos antigos. Revisão José Ribeiro Ferreira. Lisboa: Edições 70. 2002. 178 p.

233p.

Aspectos da antiguidade. Tradução Eduardo Saló. Lisboa: Edições 70. 1990.

Escravidão antiga e ideologia moderna. Tradução Norberto Luiz Guarinello. Rio de Janeiro: Graal. 1991. 208 p.

$160 \mathrm{p}$.

História antiga. Tradução Valter Lellis Siqueira. São Paulo: Martins Fontes. 1994.

. O Mundo de Ulisses. Tradução Armando Cerqueira. Lisboa: Presença. 1972. 233p.

. Uso e abuso da história. Tradução Marylene Pinto Michael. São Paulo: Martins Fontes. 1989. 258 p.

. Política no mundo antigo. Tradução Gabinete editorial Edições 70. Lisboa: Edições 70. 1997. 175 p. 

1980. 180 p.

Les premiers temps de la Grèce. Tradução François Hartog. Paris: Flammarion.

FLORENZANO, Maria Beatriz B. O mundo antigo: economia e sociedade. 13. ed. São Paulo: Brasiliense. 2004. 105 p.

GARLAN, Y. Guerra e economia na Grécia antiga. Tradução Cláudio César Santoro. São Paulo: Papirus. 1991. 203 p.

GERNET, L. Droit et institutions en Grèce antique. Paris: Flammarion. 1982. 330 p.

GIANNOTTI, J.A. O amigo e o benfeitor. In: Revista Analytica, Rio de Janeiro: UFRJ. 1996. v. 1. n. 3. 228 p.

GLOTZ, G. La cité grecque. Paris: La renaissance du livre .1928. 473 p.

. História econômica da Grécia. Tradução Vitorino Magalhães Godinho. Lisboa:

Cosmos. 1946. $371 \mathrm{p}$.

GOMPERZ, T. Pensadores griegos: história de la filosofia de la antigüedad. Tradução J. R. Bumantel. Buenos Aires: Guarania. 1952. tomo III. 638 p.

GUARINELLO, Norberto Luiz. Imperialismo greco-romano. 3. ed. São Paulo: Ática. 1994. $87 \mathrm{p}$.

HAMELIN, O. Le système d'Aristote. 4. éd. Paris: Librairie philosophique J. Vrin .1985. $427 \mathrm{p}$.

HELLER, A. Aristóteles y el mundo antiguo. Tradução José Francisco Yvars e Antonio Prometeo Moya. Barcelona: Península. 1983. 376 p.

JAEGER, W. Aristóteles. Tradução José Gaos. México: Fondo de Cultura Econômica. 1992. $556 \mathrm{p}$.

. Paidéia: a formação do homem grego. Tradução Artur M. Parreira. São Paulo: Herder. s.d. 1343 p.

KNAUSS, B. La polis: individuo y estado en la Grecia antigua. Tradução Felipe Gonzalez Vicen. Madrid: Aguilar. 1979. 301 p.

LORAUX, N. Invenção de Atenas. Tradução Lílian Valle. Rio de Janeiro: Editora 34. 1994. 445 p.

LUKÁCS, G. Ontologia del Ser Social: El Trabajo. Tradução de Antonino Infranca e Muiguel Veda, Buenos Aires: Herramienta, 2004. 206 p.

MARX, K; ENGELS, F. L’idéologie allemande: Oeuvres, III, philosophie. Organização e tradução de Maximilien Rubel. France:Gallimard (Bibliothèque de la Pléiade).1982.1976p.

. Formações econômicas pré-capitalistas. Introdução Eric Hobsbawn. Tradução João Maria. Rio de Janeiro: Paz e Terra. 1975. 136 p.

Manuscritos Econômico-Filosóficos e outros textos Escolhidos. In Os Pensadores, vol XXXV, São Paulo: Abril Cultural, 1974. 412 p.

. O Capital: Crítica da Economia Política. Tradução de Regis barbosa e Flávio R. Koth. São Paulo: Abril Cultura. 1983. Tomo I, livro 1. 301p. 
MORRAL, J. Aristóteles. Tradução Sérgio Duarte. Brasília: UnB. 2000. 123 p.

MOSSÉ, C. A Grécia arcaica de Homero a Ésquilo. Tradução José Ribeiro Ferreira. Lisboa: Edições 70. 1989. 228 p.

$135 \mathrm{p}$.

O cidadão na Grécia antiga. Tradução Rosa Carreira. Lisboa: Edições 70. 1999.

Atenas: a história de uma democracia. Tradução João Batista da Costa. 3. ed. Brasília: UnB. 1997. 140 p.

1985. $213 \mathrm{p}$.

As instituições gregas. Tradução António Imanuel Diogo. Lisboa: Edições 70.

. La tyrannie dans la Grèce antique. Paris: PUF. 2004. 214 p.

. Les grecs inventent la poltique. Bruxelles: Editions Complexe. 2005. 157 p.

. Politique et société en Grèce ancienne. France: Aubier. 1995. 241 p.

OLIVEIRA, Manfredo. A de. Ética e sociabilidade. 3. ed. São Paulo: Loyola. 2003. 290 p.

PERINE, M. Quatro lições sobre a ética de Aristóteles. São Paulo: Loyola. 2006. 109 p.

PINSKY, Carla B. (Org.). Fontes históricas. São Paulo: Contexto. 2005. 300 p.

REALE, G. Introducción a Aristóteles. Tradução Víctor Bazterrica. 2. ed. Barcelona: Herder. 1992. 209 p.

ROSS, W.D. Aristote. Paris: Payot. 1930. 419 p.

SNELL, B. A cultura grega e as origens do pensamento europeu. Tradução Pérola de Carvalho. São Paulo: Perspectiva. 2001. 326 p.

TRABULSI, J.A.D. Ensaio sobre a mobilização política na Grécia antiga. Belo Horizonte: Editora UFMG. 2001. 144 p.

. Dionisismo, poder e sociedade na Grécia até o fim da época clássica. Belo Horizonte: Editora UFMG. 2004. 294p.

VAISMAN, E. A Usina Onto-Societária do Pensamento. In: Ensaios Ad Hominem. Santo André: Estudos e Edições Ad Hominem, 1999. 287p.

VAZ, H. C.L. Escritos de filosofia IV: introdução à ética filosófica 1. 2. ed. São Paulo: Loyola. 2002. 483 p.

VERGNIÈRES, S. Ética e política em Aristóteles. Tradução Constança Marcondes César. 2. ed. São Paulo: Paulus. 2003. 301 p.

VERNANT, J-P. Mito e sociedade na Grécia antiga. Tradução Myriam Campello. 2. ed. Rio de Janeiro: José Olympio. 1999. 221 p.

As origens do pensamento grego. Tradução Ísis Borges B. da Fonseca. 6. ed. Rio de Janeiro: Bertrand Brasil. 1989. 95 p.

Terra. 2002. 504 p.

. Mito e pensamento entre os gregos. Tradução Haiganuch Sarian. São Paulo: Paz e 
VERNANT, J-P. El hombre griego. In: El hombre griego. Madrid: Alianza Editorial. 1993. 339 p. Coletânea organizada por Jean Pierre Vernant.

VERNANT, J-P; VIDAL-NAQUET, P. Mito e tragédia na Grécia antiga. São Paulo: Perspectiva. 2002. 376 p.

VERNANT, J-P.; VIDAL-NAQUET, P. Trabalho e escravidão na Grécia antiga. Tradução Marina Appenzeller. São Paulo: Papirus. 1989. 175 p.

VIDAL-NAQUET, P. Os gregos, os historiadores, a democracia: o grande desvio. Tradução Jônatas Batista Neto. São Paulo: Companhia das Letras. 2002. 354 p.

O mundo de Homero. Tradução Jônatas Batista Neto. São Paulo: Companhia das Letras. 2002. 139 p.

WOLFF, F. Aristóteles e a política. Tradução Thereza Christina Ferreira Stummer e Lygia Araújo Watanabe. São Paulo: Discurso editorial. 1999. 154 p.

ZINGANO, M. Particularismo e universalismo na ética aristotélica. In: Revista Analytica. Rio de Janeiro: UFRJ. 1996. v.1. n. 3. 228 p. 


\section{Palavras - Chave}

História, Filosofia, Política, Ética e Limite. 


\section{E.mail para contato:}

milney@terra.com.br 